Martínez Hernández José Luis

\author{
Tesis
}

Maestría en Humanidades

(Filosofía Moral y Política)

\title{
Hegel: una filosofía politica para pensar la realidad efectiva
}

\author{
Asesor \\ Rendón Alarcón Jorge
}

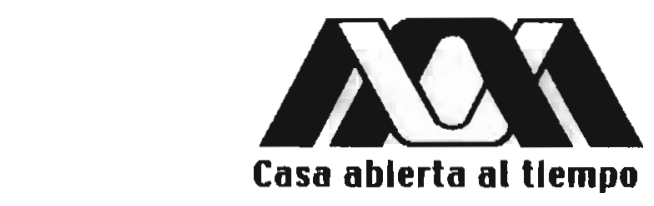

UNIVERSIDAD AUTÓNOMA METROPOLITANA

UNIDAD IZTAPALAPA 
HEGEL: UNA FILOSOFIA

POLITICA PARA PENSAR LA

REALIDAD EFECTIVA
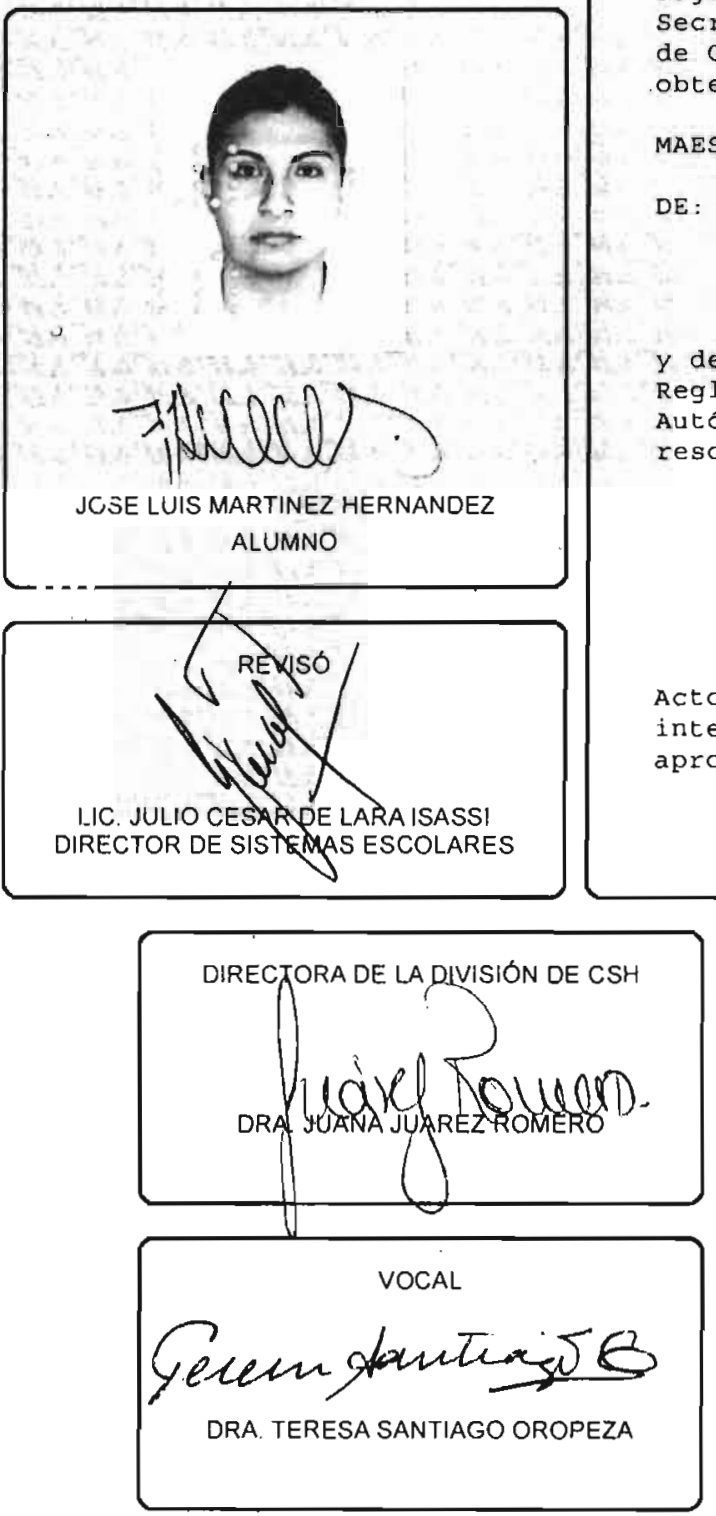

En México, D.F. se presentaron a las 12:00 horas del dí 10 del mes de diciembre del año 2014 en la Unidad Iztapalapa de la Universidad Autónoma Metropolitana, los suscritos miembros del jurado:

DR. JORGE RENDON ALARCON

DRA. TERESA SANTIAGO OROPEZA

DR. SERGIO REREZ CORTES

Bajo la Presidencia del primero y con carácter de Secretario el ultimo, se reunieron para proceder al Examen de Grado cuya denominación aparece al margen, para la obtención del grado de:

MAESTRO EN HUMANIDADES (FILOSOFIA)

DE: JOSE LUIS MARTINEZ HERNANDEZ

$y$ de acuerdo con el artículo 78 fracción III del Reglamento de Estudios Superiores de la Universidad Autónoma Metropolitana, los miembros del jurado resolvieron:

\section{APROBAR}

Acto continuo, el presidente del jurado comunicó al interesado el resultado de la evaluación $y$, en caso aprobatorio, le fue tomada la protesta. 
En memoria de mi madre, Mari, quien aunque ya no está con nosotros, vive entre nosotros.

... Ahora su memoria es para mí la más sagrada, y todas las veces que me asalta su recuerdo, puesto que no puedo corporalmente, la abrazo y beso en espíritu con la más dulce de las gratitudes.

Luis Vives

Quem di diligunt, adolescens moritur.

Plauto 


\section{ÍNDICE}

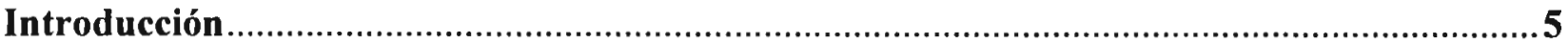

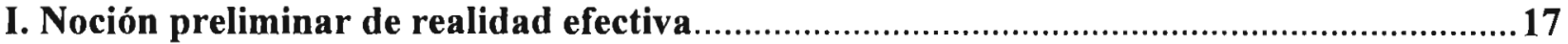

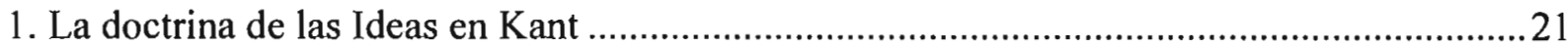

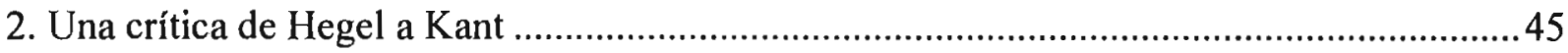

II. La categoría de realidad efectiva: posibilidad, contingencia y necesidad.......................79

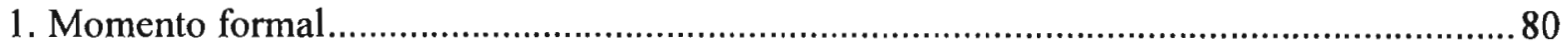

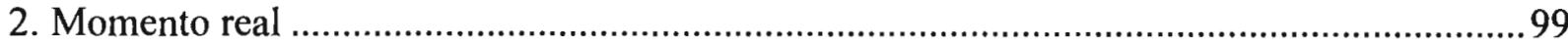

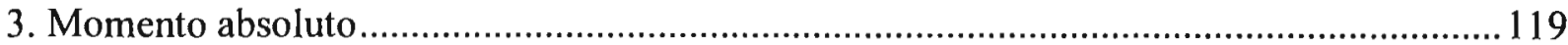

III. Implicaciones prácticas de la realidad efectiva ...................................................141

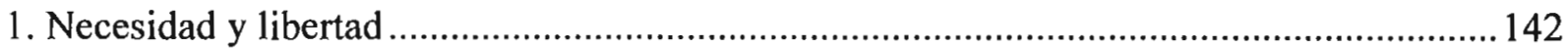

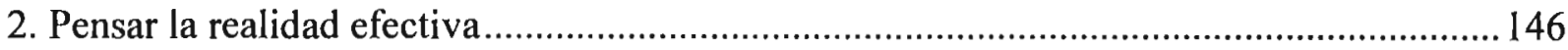

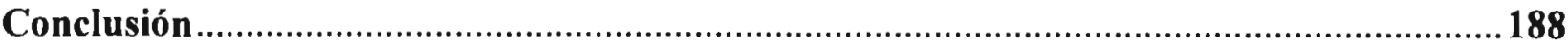

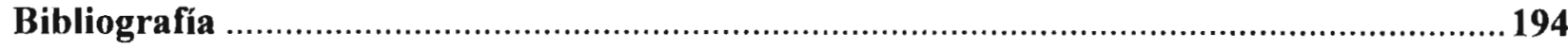




\section{Introducción}

En 1956 Peter Laslett anunciaba, como signo de un sentir generalizado en aquel momento, la muerte de la filosofía política ${ }^{1}$; la cual, suele decirse, sólo vio su resurgimiento con la aparición de Una teoría de la justicia de John Rawls en 1971. Pero ¿qué condiciones condujeron a enunciar tanto la muerte como la posterior resurrección de esta disciplina? Pensamos que tal sentencia sólo es posible si se considera a la filosofía política, en contraposición a la ciencia política, como un discurso meramente normativo. En efecto, se puede decir que las más de las veces, la filosofía política se ha definido como un discurso puramente normativo, esto es, como una teoría que pretende prescribir lo que debe ser el orden político. Mientras que, con frecuencia, la ciencia política ha sido definida como un discurso meramente descriptivo, es decir, como una teoría que se propone describir lo que es, de hecho, el orden político.

Pero, entendida exclusivamente como un discurso normativo, la filosofía política tropezó con diversas dificultades, ya que, al ser considerada como algo puramente abstracto, no recibió los favores de las ciencias sociales en general ni de la ciencia política en particular. ${ }^{2}$ Se oía decir que mientras la filosofía sólo

\footnotetext{
${ }^{1}$ Cfr., Peter Laslett, Philosophy, Politics and Society (Cambridge: Blackwell, 1964), "Introduction".

${ }^{2}$ La filosofía política fue en general rechazada como una mera especulación normativa, e incluso quedó ensombrecida ante el esplendor de las ciencias sociales; éstas daban por superada la metafísica y, con ella, la
} 
era valorativa y prescriptiva; la ciencia política, por el contrario, era explicativa y descriptiva.

En suma, a partir de esta visión reduccionista, es que, pensamos, se llegó a declarar la muerte de la filosofía política en plena mitad del siglo XX así como su posterior resurrección hacia el final del mismo (ya que dicha visión parece sugerir que toda filosofía política carente de un nivel normativo, en el sentido aquí descrito, en realidad no merece tal nombre). Esto hace surgir una serie de interrogantes: ¿debe la filosofía política enfocarse al ser o al deber ser del orden político? ¿tiene una función descriptiva o prescriptiva? ¿se ha de inclinar al realismo o al normativismo? En realidad esta disyuntiva se trata de un falso dilema, pues, más que contraponerse, estas perspectivas se complementan entre sí; aún sin saberlo, todo realismo contiene un cierto normativismo y todo normativismo contiene, a su vez, un cierto realismo.

Con todo, parece innegable que la filosofía política ha sido entendida en exclusiva como un discurso puramente normativo ${ }^{3}$. Pero el problema con las doctrinas normativas en general es que parecen compartir un supuesto metafísico que no someten a crítica y que, por tanto, les otorga un carácter crítico limitado, tal supuesto es: la separación entre las ideas y la realidad (es así que contraponen el Estado real a un Estado ideal). Pero, a pesar de todo, es precisamente esta separación la que les brinda su carácter crítico, por lo que no pueden renunciar a esta escisión entre ser y pensar sin por ello renunciar también a su función crítica.

filosofía (o por lo menos le restaban importancia aduciendo que todas las cuestiones que esta última se planteaba podían ser reducidas a problemas científicos).

${ }^{3}$ Resulta innegable que el ámbito normativo ha sido una cuestión predominante en la historia de la filosofía política. De ahí que entre sus principales problemas se ha planteado las más de las veces, no cuáles son las formas en las que históricamente se ha organizado el orden político, sino cuál debe ser la organización legítima del mismo. Así, con el objetivo de determinar racionalmente en qué orden político deben vivir los seres humanos, la filosofía política se ha abocado principalmente a construir modelos normativos que permitan la justificación de las instituciones políticas modernas. Esto explica por qué el contractualismo, por ejemplo, se convirtió en una corriente de pensamiento que dominó como el modelo normativo paradigmático para juzgar la legitimidad del orden político moderno. 
No obstante, retomando la categoría de realidad efectiva o efectividad (Wirklichkeit) en Hegel podemos decir que si bien la filosofía política ha de ser crítica, dicha crítica no necesariamente se ha de fundar en la contraposición entre una idea y la realidad, sino que se puede dar a través del conocimiento mismo de la realidad (hay aquí una unidad entre conocimiento y crítica que, vale decir, no implica identificar compresión y justificación).

A nuestro juicio, la filosofía hegeliana, centrada en la categoría de realidad efectiva, permite situarse en el presente para pensarle desde sí mismo y juzgarle críticamente. Pues la noción misma de realidad efectiva plantea la exigencia de situarse en el presente para criticarlo desde lo que efectivamente es. En este sentido, nuestro autor critica la formulación de situaciones ideales que pretendan determinar de antemano cómo debe ser la situación actual sin ocuparse de cómo es en realidad. Así, a diferencia de la filosofía meramente normativa, la categoría de realidad efectiva en Hegel nos aporta un enfoque particularmente crítico para afrontar los problemas políticos sin la necesidad de formular un Estado idealmente racional para contraponerlo al Estado real. A pensar esta categoría se vio enfocada nuestra investigación toda.

El Capítulo Primero de nuestra investigación da una noción preliminar de la realidad efectiva en Hegel, la cual, a nuestro parecer, puede ser comprendida mejor contraponiéndola a las Ideas de la razón en Kant (cabe señalar que, aunque se distanció notablemente de ella, Hegel siempre se consideró un heredero de la filosofía kantiana; por lo que respecta a la filosofía política, la diferencia más marcada entre ambos filósofos se encuentra, por lo demás, en la forma de entender la crítica).

Es así que el Primer Apartado de este Capítulo expone la doctrina de las Ideas en Kant. Ahí se sostiene que las Ideas kantianas no surgen sino de la distinción entre razón teórica y razón práctica (entre naturaleza y libertad), y no así de la experiencia. Las Ideas de la razón no se pueden realizar nunca en 
la experiencia, sino que sólo fungen como principios normativos que guían la acción humana, se trata de Ideas regulativas que prescriben cómo debe ser el orden práctico (moral y político).

En tanto las Ideas tienen una función meramente regulativa, en cuanto fungen como una guía para la vida práctica, en especial para la política, han de establecer cómo debe ser el orden político que pretenda ser racional, esto es, cómo debe ser un orden estatal de acuerdo con la razón.

Kant establece la Idea de un Estado ético como el fin último de la actividad humana, pero en tanto su realización resulta completamente imposible, propone la Idea de un Estado jurídico que funja como medio para alcanzar aquel fin. Empero, en tanto la realización de este último resulta igualmente imposible, se ha de considerar simplemente como el sustituto del primero, es decir, como una Idea inalcanzable que ha de guiar las acciones humanas hacia la perfección. En este sentido, concibe su doctrina muy cercana a la teoría platónica de las Ideas. En efecto, con el fin de aclarar qué entiende por Idea de la razón, Kant recurre a Platón. De acuerdo con nuestro filósofo de Königsberg, las Ideas platónicas, lo mismo que como él las concibe, se encuentran más allá de la experiencia y tienen una función puramente práctica.

El Apartado Segundo de este Capítulo Primero, está dedicado a una crítica de Hegel a Kant. A partir de la categoría de realidad efectiva hegeliana se puede dirigir una crítica a las Ideas kantianas, en tanto aquélla, a diferencia de éstas, no se aboca al deber ser, sino al ser mismo del orden político. ${ }^{4}$ No obstante, para nuestro profesor berlinés, pensar el orden político, no es pensarle en su inmediatez, sino justo en su realidad efectiva, esto es, en el proceso que ha hecho del mismo un resultado.

\footnotetext{
${ }^{4}$ Empero, cabe señalar que en la presente investigación no se contrapone el ser al deber ser en el ámbito de la moral (que Hegel desarrolla a fondo en "La concepción moral del mundo" de la Fenomenología del espíritu), sino que se limita a su contraposición en el ámbito de lo político.
} 
Así, Hegel establece de inmediato una distinción entre la realidad sin más (Realität) y la realidad efectiva (Wirklichkeit); esta última se refiere a la realidad plenamente pensada, a la actividad reflexiva que reconoce el proceso que explica la realidad tal como aparece. La realidad efectiva es la realidad completamente aprehendida por el pensamiento, realidad que no es sino producto de la actividad teórico-práctica del ser humano.

En tanto Hegel no parte, como Kant, de la separación entre una razón teórica y una razón práctica, no tiene necesidad de hallar una facultad (como la de juzgar) que les unifique, o aproxime, mediante la postulación de ciertas Ideas; que es donde, sostenemos, surge el normativismo kantiano. En tanto para Hegel, sin práctica no hay teoría y sin teoría no hay práctica, es el mismo proceso de la realidad efectiva (como unidad de ser y pensar) el que hace aparecer su propia normatividad, sin que ésta se le imponga desde fuera.

En otras palabras, no hay realidad independiente del pensamiento: si no existiera más que realidad, no habría de hecho realidad, pues ésta sólo es porque es pensada; fuera de la determinación del pensamiento, lo real equivale a la nada. Del mismo modo, no puede haber pensamiento independiente de la realidad: si no hubiera más que ideas, no habría de hecho ideas, porque la idea es sólo aquello que se manifiesta en la realidad; sin una realidad que pensar, el pensamiento equivale igualmente a la nada. De este modo, no hay una realidad anterior al pensamiento, ni un pensamiento anterior a la realidad, de donde pudiera surgir normatividad alguna. Es en el mismo y único proceso, en el que se constituyen como resultado, que hacen aparecer lo normativo: la realidad como idea y la idea como realidad.

De tal modo que, en torno a las Ideas platónicas, Hegel piensa, a diferencia de Kant, que no son algo que se encuentre más allá de la experiencia, sino que están presentes en lo real. No obstante, aunque Hegel sostiene que las Ideas de Platón se hallan efectivamente en la existencia, 
piensa que, a diferencia de la actividad aristotélica, se encuentran sólo en potencia, mas no así en acto. Del mismo modo que piensa que las Ideas kantianas no encuentran realidad alguna, ni pueden encontrarla (cosa que el mismo Kant no desmentiría).

Por lo demás, la crítica al normativismo kantiano va más allá de una crítica a Kant, pues se extiende a aquellas teorías del consenso que pretenden fundarse en su doctrina y que, por consiguiente, comparten el supuesto metafísico de una independencia entre las ideas y la realidad. ${ }^{5}$

El Capítulo Segundo de la investigación, que es el que mayor dificultad entraña, se enfoca directamente en la categoría de realidad efectiva. Ésta es ante todo una categoría lógica (de ahí que entre las diferentes apariciones que tiene en la producción hegeliana, su desarrollo más sistemático se encuentra en la Ciencia de lógica). En la Lógica, la realidad efectiva pretende dar cuenta del proceso inteligible que hace que la realidad sea como es (que lo que es sea precisamente como es).

Pero en tanto permite pensar lo que efectivamente es, podemos ver la realidad efectiva actuando en la vida práctica. Ella nos permite pensar el presente desde el presente mismo. En el terreno político, la realidad efectiva permite juzgar y evaluar el presente político desde sí mismo, de acuerdo con su propia efectividad, y no desde un criterio externo como lo sería un ideal.

Con ello, la realidad efectiva se opone a toda idea trascendente o inmanente al mundo mismo. Afirma que fuera de sus determinaciones pensadas, la realidad carece de consistencia alguna. Así, la realidad efectiva pretende determinar la estructura esencial de lo real, y para ello echa mano de las modalidades con las que el pensamiento puede reconocer lo realmente

\footnotetext{
${ }^{5}$ Existen al menos dos razones por las que se pone en consideración aquí la filosofía de Kant. Primero, la filosofía hegeliana resulta más comprensible contraponiéndola con la kantiana. Segundo, la filosofía kantiana constituye la base de aquellas doctrinas normativas, fundadas en el consenso, que predominan en la actualidad (en efecto, actualmente las principales teorías normativas de la filosofía política se basan, o al menos así lo pretenden, en la doctrina práctica de Kant.
} 
efectivo: la posibilidad, la contingencia y la necesidad (en la Ciencia de la lógica, el examen de estas modalidades corresponde a la "Doctrina de la esencia”).

Estas categorías modales son desarrolladas por Hegel en su momento formal, real y absoluto. De ahí podríamos resumir el movimiento de las modalidades diciendo que Hegel termina la reflexión sobre las mismas con la necesidad absoluta, con lo cual nos ahorraríamos mucho, pero es el mismo Hegel el que ha insistido en la necesidad de su demostración, esto es, el que una modalidad, en el momento de afirmarse, mediante su contradicción e insuficiencia, conduzca necesariamente a otra. De lo contrario, nada se ha demostrado (y resulta igualmente válido afirmar la absoluta necesidad del mundo como la absoluta contingencia del mismo). Esto quizá explica el que este Capítulo se haya detenido tan largamente en la exposición de las categorías modales.

Aquí se han seguido los pasos de Hegel que, fiel a su proceder, va de lo más abstracto a lo más concreto. En la Lógica, el desarrollo del momento más abstracto de la realidad efectiva conduce a su modo más concreto que es el de la necesidad absoluta. En esta modalidad la razón logra pensar la absoluta necesidad del mundo presente en tanto mundo pensado. Pero para llegar a ello es menester mostrar todo su desarrollo.

Así, el Primer Apartado de este Capítulo Segundo aborda el momento formal de las modalidades en las que se presenta la realidad efectiva. La primera modalidad con la que el pensamiento trata de pensar lo efectivo es la posibilidad formal. Pero en tanto lo formalmente posible es de la misma manera que pudo no ser, es considerado como contingente, pues lo contingente se define justo como aquello que podría no haber sido.

No obstante, aunque pudo no ser, lo contingente ya es algo efectivo. $\mathrm{Y}$ en tanto fue su propia posibilidad la que se realizó, y no otra, la cosa no podría 
haber sido de otra manera, por lo que se muestra como algo necesario (como algo formalmente necesario). No obstante, esta necesidad formal no satisface las exigencias del pensamiento especulativo, pues mantiene todavía un carácter contingente, por lo que para reducir la contingencia y elevarse a una necesidad más alta, la reflexión da paso al momento real de las categorías modales.

El Apartado Segundo de este Capítulo aborda dicho momento real de las modalidades. En este momento lo efectivo se muestra como una multiplicidad de propiedades, se trata de una realidad efectiva real (real Wirklichkeit). La primera modalidad con la que el pensamiento trata de hacer inteligible esta realidad realmente efectiva es la posibilidad real. En tanto una cosa realmente efectiva no es sino por el conjunto de condiciones que la determinan, en el momento en que el conjunto entero de condiciones de una cosa se halla presente, ella es ya realmente efectiva.

Pero, si es posible transitar de la posibilidad real a la efectividad real, esto es, si es posible establecer el tránsito del conjunto de condiciones concretas a la existencia concreta de una cosa, entonces no se está sino haciendo explícita la necesidad real de la misma. Empero en tanto el que una cosa devenga necesaria depende de que se realicen sus condiciones de existencia, y en tanto la realización de las mismas, y no de otras, resulta contingente, entonces la necesidad real no logra excluir del todo la contingencia. En tanto mantiene todavía un carácter contingente, la necesidad real se convierte en necesidad relativa. Pero el pensamiento especulativo no se conforma con algo sólo relativamente necesario y busca una síntesis más alta, una necesidad absoluta, lo cual exige pasar al momento absoluto de las categorías modales.

El Apartado Tercero de este Capítulo Segundo se ve enfocado a tratar tal momento absoluto de las modalidades. En este tercer momento lo efectivo se presenta como una realidad efectiva absoluta, como una realidad que no 
depende de la realización de sus condiciones, sino de sí misma, de su propia autoconstitución, puesto que lo real y sus condiciones son lo mismo, coinciden de manera absoluta. La primera modalidad con la que el pensamiento trata de pensar la realidad absolutamente efectiva es la posibilidad absoluta. En tanto esto explica por qué lo efectivo ha devenido efectivo, por qué lo que es es lo que es, explica entonces su presencia necesaria en la existencia.

En este momento lo efectivo muestra, retrospectivamente, qué condiciones se han tenido que cumplir para que dicho efectivo deviniera precisamente él mismo, y no algún otro, es decir, para devenir algo absolutamente necesario. ${ }^{6} \mathrm{Al}$ contrario del momento real, el momento absoluto muestra que las condiciones constitutivas de la cosa son el resultado de la propia actividad reflexiva que piensa la cosa, y no meras presuposiciones o algo dado.

En tanto aquello que da cuenta de la necesidad absoluta de lo que es, de lo efectivo, es el proceso que explica su razón de ser en la existencia. Aquello que daría cuenta de una cosa como algo absolutamente necesario sería la explicitación del proceso que explicaría su presencia en la existencia. Nada determina de antemano que se dé una cosa y no otra, pero una vez dada (como resultado) cierta cosa, ésta muestra su razón de ser al hacer explícito el proceso que le ha traído a la existencia. Una vez que un proceso ha devenido en cosa, entonces se puede determinar el itinerario específico que le ha hecho devenir cosa. Sólo entonces se puede explicar por qué una cosa es como es, y no de otra manera, esto es, se puede determinar su necesidad absoluta. ${ }^{7}$

\footnotetext{
${ }^{6} \mathrm{Si}$ la reflexión puede determinar el conjunto específico de condiciones que han tenido que realizarse para que lo efectivo haya devenido justo ese efectivo, y no otro, entonces está mostrando su necesidad absoluta.

${ }^{7}$ En resumen, se puede decir que la necesidad absoluta consiste en un mismo y único proceso reflexivo en el que el pensamiento constituye enteramente a la cosa como tal y en tanto ésta no es sino conforme al propio pensamiento, éste se constituye a la vez a sí mismo. La constitución de la cosa y la autoconstitución del pensamiento ocurren de modo simultáneo. El pensamiento constituye la cosa pensada en el mismo proceso de pensarla, y se constituye a sí mismo pensándose en el proceso mismo de constitución de la cosa como tal. El pensamiento que reflexiona sobre la cosa lo hace, a la vez, sobre sí mismo.
} 
Una vez alcanzada la necesidad absoluta de lo realmente efectivo en el plano lógico, el Capítulo Tercero se ve enfocado ahora a las implicaciones prácticas de la realidad efectiva. En el momento en el que la reflexión reconoce que todo el proceso que va desde la presuposición tanto de la cosa como de sus condiciones hasta la reconstitución de ambos en su unidad, no es sino la obra del pensamiento, entonces éste alcanza la necesidad absoluta. Y en tanto el pensamiento asume el proceso entero de reconstitución como su propia obra, se identifica con la libertad, pues es por sí mismo, y no por otro. $\mathrm{Al}$ autoconstituirse, el pensamiento deja de ser por algo ajeno a él mismo, se torna libre.

El Apartado Primero de este Capítulo expone sucintamente la relación entre la necesidad y la libertad. Con la modalidad de necesidad absoluta se logra pensar la existencia necesaria de las cosas, y cuando reconoce que dicha necesidad no es sino resultado del proceso reflexivo, entonces ya no se está hablando tanto de necesidad como de libertad. En su actividad libre, el pensamiento produce tanto la cosa como sus condiciones, con lo que suprime todo presupuesto $\mathrm{y}$, en consecuencia, alcanza su necesidad absoluta. La necesidad absoluta del mundo efectivo es el resultado de la actividad del pensamiento en su libertad.

Trasladando esto al ámbito político, se puede decir que si la libertad crea la necesidad absoluta de lo realmente efectivo ${ }^{8}$, entonces, la filosofía no ha de tratar de legislar sobre la realidad como lo pretenden las doctrinas normativas, sino que se tiene que limitar a comprender. Ello no significa que se comporte de un modo acrítico y justifique el mundo existente, sino que a través de la comprensión del presente se puede formular una crítica al presente mismo. Así, no es que Hegel abandone por completo el nivel normativo de la filosofía, sino

\footnotetext{
${ }^{8}$ La libertad se da forma de mundo, que al no poder ser de otro modo más que como la libertad lo constituye, se torna necesario. La libertad se otorga su propia necesidad al realizarse como mundo efectivo. La necesidad es el resultado propio de la libertad.
} 
que hace de ello algo inmanente a la comprensión misma del mundo, que no es sino obra de la libertad.

El Apartado Segundo de este último Capítulo Tercero se ve destinado a pensar la realidad efectiva bajo esta clave. Este apartado pretende mostrar que, con la categoría de realidad efectiva, el pensamiento se puede situar en el presente para pensarlo desde sí mismo, y no ya desde un orden externo. De modo que si hay alguna normatividad en Hegel, ésta ha de ser enteramente interna al proceso mismo, se ha de tratar de un normativismo inmanente a la propia autoconstitución de la libertad.

Si se logra mostrar que la filosofía es capaz de pensar efectivamente el presente como algo absolutamente necesario (esto es, si muestra que la realidad efectiva es plenamente racional), entonces el presente mismo puede otorgar el criterio para juzgarle desde sí mismo. Esto a diferencia del normativismo, para el que, en tanto la realidad se le presenta como irracional o como algo incognoscible, se requiere hallar un principio racional fuera de lo real para poderle juzgar.

En tanto el presente se les muestra como un sinsentido, las filosofías normativistas lo evaden y optan por desarrollar elaboradas teorías sobre lo que debe ser, por lo que su crítica se ve limitada (se muestra como un mero rechazo a la situación actual, lo cual depende de cómo se les aparezca subjetivamente el mundo). Pero para Hegel, la filosofía no ha de evadir el presente y formular cómo debería ser si fuera racional, sino que, en tanto es ya racional, no hay necesidad de formular mundos ideales para pensarle, pues es su propia racionalidad la que permite criticar aquello que le contradice y que, por ello, se ha de transformar.

Con todo, el objeto general de nuestra investigación ha sido poner énfasis en la función que Hegel le otorga a la filosofía y que lo distancia de otros pensadores como los teóricos del normativismo. Asimismo ha sido nuestra 
intención subrayar que la filosofía hegeliana constituye una forma peculiar de enfrentar los problemas actuales, pues el mostrar que el pensamiento puede aprehender la realidad efectiva trae consecuencias revolucionarias para el quehacer filosófico en general y para la filosofía política en particular.

Y aunque nuestro objetivo consistió en centrar la categoría de realidad efectiva en el terreno político, antes fue necesario su despliegue como categoría lógica. Esto explica que nuestra investigación se vea por momentos mayormente inclinada a una cuestión lógica, e incluso metafísica. Lo cual no deja de tener importancia, ya que el sumergirnos en estas cuestiones abstractas nos permite criticar algunos supuestos metafísicos en los que se fundan ciertas doctrinas políticas. En este sentido, la elección de cómo enfrentar los problemas actuales no puede depender sino de una primera elección metafísica. Es sólo la adopción de una cierta metafísica lo que nos permitirá reconciliar el pensamiento con la realidad y, en esta medida, dejar de postular ciertas ideas regulativas que resulten irrealizables en el dominio de lo real.

$\mathrm{Al}$ recuperar la categoría de realidad efectiva en la presente investigación hemos tratado de mostrar que ella nos permite reconciliarnos con el mundo. Dicha categoría trata de llevarnos a la consciencia de que el mundo no es sino el resultado de la actividad humana y, en consecuencia, la transformación del mismo está plenamente en las manos del ser humano. A través de su libre acción, el ser humano hace del mundo que habita su propia obra, lo hace algo absolutamente necesario y, por tanto, posee la capacidad de transformarlo. Hegel trata de conducirnos a la conciencia de ello a través de la categoría de realidad efectiva, esto es, reconociendo que todo lo racional es realmente efectivo y que todo lo realmente efectivo es racional. 


\section{Noción preliminar de realidad efectiva}

En 1964 Isaiah Berlin advertía que <<ninguna obra importante de filosofía política ha aparecido en el siglo veinte $>>9$, y ocho años antes su discípulo Peter Laslett había ya declarado que $<<$ por el momento, de cualquier modo, la filosofía política está muerta>>.10 Más allá de la verdad de estas sentencias, lo relevante es que parecían expresar un sentir generalizado a mitad del siglo anterior sobre la situación de la reflexión filosófica en el terreno político. En la actualidad, a pesar de que se habla de un resurgimiento de la filosofía política ${ }^{11}$, lo cierto es que esta disciplina filosófica como en otras épocas sigue sufriendo de un serio rechazo (una muestra de ello puede ser la independización, cada vez mayor, de las ciencias sociales con respecto a la filosofía).

Resulta llamativo que, guardando la distancia, actualmente podamos coincidir con el diagnostico poco alentador que en 1821 Hegel hacía de la filosofía; la cual, consideraba, había caído en una "ignominiosa decadencia" y encontraba por todas partes "un descrédito y desprecio general". Pero, de acuerdo con nuestro autor, si la filosofía encuentra este rechazo generalizado se debe a que, fundada en la mera subjetividad, ha tendido a una reflexión puramente abstracta y se ha alejado cada vez más del pensamiento concreto, y es ello lo que le ha conducido a colocarse en una situación indigna y decadente. Con lo que es la propia filosofía la que se ha ganado esta imagen negativa de sí misma.

Esta visión negativa descansa sobre todo en la tendencia de la filosofía a crear mundos ideales que se contrapongan al mundo actual, lo cual es muy

\footnotetext{
${ }^{9}<<[\ldots]$ no commanding work of political philosophy has appeared in the twentieth century $>>$ "Does Political Theory Still Exist?", en Peter Laslett, Philosophy, Politics and Society (Second Series) (Cambridge: Blackwell, 1964), p. I.

$10<<$ For the moment, anyway, political philosophy is dead>>. Peter Laslett, Philosophy, Politics and Society (First Series) (Cambridge: Blackwell, 1956), "Introduction”, p. VII.

11 Tradicionalmente se considera que la "resurrección" de la filosofía política vino dada por la aparición de la obra de John Rawls, Una teoría de la justicia, en 1971.
} 
común en filosofía política. Pues en la vida ordinaria, la formulación de mundos ideales es considerada como un simple producto literario que surge del espíritu "profundo" del filósofo. A la vista de la consciencia ordinaria, estos mundos ideales parecen un mero producto de la pura ensoñación, por lo que ve a la filosofía como algo poco serio e incluso como un pensamiento que merecería cierto recelo. Tal vez la consciencia ordinaria no tenga razón del todo frente al pensamiento filosófico, pero sí la tiene, en cierto sentido, al señalar que la reflexión en el campo de la filosofía política tiende a alejarse de la vida concreta y sumergirse en la abstracción. Es sobre todo en el mundo moderno, con el surgimiento de la teoría contractualista, donde comienza un gran auge de doctrinas políticas que buscan precisar un mundo ideal que se contraponga al momento insatisfactorio por el que se atraviesa. Pero el que la formulación abstracta de mundos ideales en filosofía tenga su más amplio desarrollo en el mundo moderno se debe a razones muy específicas.

Recordemos que sobre todo a partir de la Modernidad, la filosofía política se ofreció a los seres humanos como una actividad reflexiva para pensar y, a partir de ello, transformar su realidad. Pero en tanto dicha transformación requería previamente de una adecuada evaluación de lo real, el problema de fondo era justo cómo pensar esta realidad presente. En el mundo moderno, con el cuestionamiento de la teleología antigua y de la teología medieval, el ser humano intentó dar cuenta de su realidad política confiando sólo en el poder de la razón.

Es así que dejando atrás instancias como la Naturaleza o Dios, la filosofía clásica moderna pretendió dar razón del orden político con base en la formulación de un orden racional (fundado en la libertad e igualdad humanas). De modo que la filosofía política moderna se enfocó en buscar la Idea de un Estado racional a partir del cual se pudiera valorar la legitimidad del Estado real; legitimidad que se juzgaba justo en función de la proximidad del Estado real con respecto al Estado racional. Así, la Idea de un Estado tal fungía como 
un modelo normativo, esto es, de un modelo que establece cómo debe ser el Estado actual si pretende ser racional. ${ }^{12}$ Esta postura normativa sostenida por los autores modernos ha prevalecido hasta la actualidad como modelo paradigmático de legitimación del orden político, pero esta postura que pretende determinar cómo debe ser el mundo político, es ya criticada en la propia Modernidad por Hegel.

De acuerdo con Hegel, la filosofía política no debe enfocarse a lo que el orden político debe ser, sino a lo que efectivamente es, esto es, a la efectividad de lo real. Ciertamente, la filosofía debe adoptar una postura crítica frente al presente para transformarlo, pero no debe hacerlo desde una Idea o un ideal de un orden político, sino desde el presente mismo. La filosofía política, sostiene Hegel, no se debe enfocar a crear modelos normativos con los cuales juzgar el presente y determinar lo que ha de ser, sino que debe precisar aquellas categorías que le permitan concebir el presente en su incesante actualidad, esto es, en su devenir. Debe buscar aquellos conceptos que le permitan comprender el proceso que ha llevado al presente a ser tal como es para, en virtud de ello, transformarlo conforme a las exigencias que el proceso mismo en el que se encuentra activo ya demanda.

Hegel confía esta tarea de pensar el presente desde sí mismo a la categoría de realidad efectiva o efectividad (Wirklichkeit), que tiene su desarrollo como concepto lógico, pero que tiene una implicación abiertamente política. En el ámbito político la categoría de efectividad permite pensar el presente en el proceso que lo ha llevado a ser, que lo ha hecho ser tal como es y que lo hace ser necesario (como veremos más adelante, la noción de realidad

\footnotetext{
${ }^{12}$ Es en la tradición contractualista, donde se puede constatar con claridad que es el nivel normativo el que ha predominado en el ámbito de la filosofía política moderna, por lo que su preocupación central ha consistido en establecer cómo debe ser organizado un orden político legítimo, y no la forma en la que ha sido organizado de hecho en la historia. De este modo, la filosofía política se ha enfocado principalmente a establecer modelos normativos que determinen la legitimidad del orden político.

A partir de ello, aunque se trata de una visión reduccionista, se suele definir a la filosofía política como un discurso normativo. Este normativismo se basa en la idea de que en tanto la filosofía debe mantener una postura crítica frente a la realidad política, entonces debe necesariamente plantear una distinción entre lo que el orden político es y lo que debería de ser conforme a principios racionales.
} 
efectiva se ve íntimamente vinculada a la necesidad). Pero esto no implica que Hegel excluya el nivel normativo de la filosofía, sino que hace de él algo inmanente a la compresión misma del presente. La realidad efectiva declara que, en su mismo proceso, el presente contiene ya su propia normatividad, la cual posibilita su transformación sin la necesidad de postular una Idea o un ideal externos que determinen cómo debe ser el orden político actual.

La realidad efectiva representa el momento lógico en el que la realidad es completamente reconstituida por el pensamiento como algo absolutamente necesario, lo cual trasladado al ámbito de la filosofía política plantea la exigencia de pensar la necesidad del presente para criticar aquello que tiene de contingente. La filosofía política no se debe aventurar, como repetidamente se pretende, a idear cómo debe ser el Estado perfecto, sino que ha de tratar de concebirlo en su propio devenir.

A partir de aquí, pensamos, es posible desarrollar una crítica a todos aquellas doctrinas que pretenden reducir la labor filosófica a una mera prescripción normativa. No obstante, en la presente investigación nos limitaremos a la crítica que Hegel dirige contra la filosofía kantiana. Hegel considera a Kant como su antecesor inmediato en sus reflexiones especulativas, sin embargo siempre intentó desmarcarse del mismo, sobre todo en su manera de proceder. Heredero del normativismo contractualista, Kant sostiene que la filosofía política debe pensar el presente, en última instancia, desde la Idea de un Estado racional, la cual ha de fungir como un modelo normativo para, a partir del mismo, prescribir cómo debe ser el Estado real y juzgar su legitimidad. De este modo, Kant le encomienda la importante tarea de guiar la actividad política a las Ideas de la razón. Y serán estas Ideas, entendidas como principios prescriptivos, a las que Hegel dirigirá su crítica con la categoría de efectividad. 
En las siguientes líneas expondremos la doctrina kantiana de las Ideas. Nos concentraremos específicamente en la Idea de Estado e intentaremos mostrar que, como modelo normativo, no surge sino de la separación entre un nivel descriptivo y un nivel prescriptivo, lo que en términos kantianos corresponde a la separación entre razón teórica y razón práctica. A continuación examinaremos cómo la distinción inicial entre teoría y práctica conduce a Kant a un dualismo entre el ser y el deber ser. Examinaremos cómo esta dualidad lleva a Kant a postular las Ideas de la razón, y será en el esfuerzo por su realización, que la capacidad de juzgar tratará de reducir la distancia entre el ser y el deber ser. ${ }^{13}$

\section{La doctrina de la Ideas en Kant ${ }^{14}$}

En la actualidad algunas de las principales teorías éticas, políticas y jurídicas se basan en la filosofía práctica de Kant. La vigencia de la doctrina práctica kantiana parece residir hoy en la fuerza normativa que contiene su filosofía. Esta normatividad se funda en las Ideas de la razón ${ }^{15}$, las cuales deben guiar la actividad práctica de los seres humanos en tanto agentes racionales. De acuerdo con Kant, $<<$ en la filosofía todo depende de Ideas $>>16$,

${ }^{13}$ En esta exposición nos basaremos principalmente en la Crítica de la razón pura (cuya segunda edición data de 1787), y en el desarrollo de la Crítica del juicio (también denominada Crítica del discernimiento, obra de 1790), y que es donde Kant plantea explícitamente la división de su sistema. Estas obras kantianas corresponden a su primera y tercera Crítica, respectivamente; ya que la segunda, la Crítica de la razón práctica, apareció en el año 1785, esto es, cuatro años después de la primera edición de la Crítica de la razón pura (1781).

${ }^{14}$ En adelante emplearemos el término Idea comenzando con letra mayúscula para diferenciarlo de los meros pensamientos que comúnmente son llamados "ideas", ya que la Idea en Kant (lo mismo que en Hegel) posee un significado específico que se irá aclarando a lo largo de la investigación.

${ }^{15}$ Kant distingue entre las Ideas absolutamente necesarias de la razón — que son Dios, la libertad, la inmortalidad del alma - y las Ideas de la razón que resultan necesarias como principios regulativos. Sin pretender agotar las Ideas regulativas en Kant, enlistemos algunas de ellas: la Idea de un Estado republicano, de un Estado ético, de una Federación de Estados y la Idea de un Estado cosmopolita. En el presente texto nos ocuparemos sólo de las dos primeras, ya que son las que se refieren al ámbito interno del Estado, mientras que las dos últimas se refieren a la relación externa entre los Estados. Además de estas Ideas, Kant habla de la Idea de un bien supremo o sumo bien que, sin embargo, no abordaremos en el presente texto, pues en tanto tal Idea corresponde por excelencia al ámbito moral, su tratamiento nos desviaría de nuestro tema.

${ }^{16}$ Immanuel Kant, Lógica (Madrid: Akal, 2000), p. 143. 
pero "la Idea se opone a los conceptos empíricos", pues de acuerdo con nuestro autor <<la Idea es un concepto de razón cuyo objeto no puede hallarse en modo alguno en la experiencia $>.17$ Sin embargo, para Kant la Idea contiene un aspecto positivo, ya que <<una Idea no es otra cosa que el concepto de una perfección no encontrada aún en la experiencia $>.18$

En tanto contiene el concepto de perfección, la Idea funge como un principio normativo; principio que, a su vez, tiene su origen en la distinción kantiana entre teoría y práctica (efectivamente, enseguida veremos que las Ideas de la razón, como principios normativos, surgen a partir de esta distinción). En efecto, en el sistema kantiano encontramos que la razón cuenta con dos maneras de conocer conceptualmente sus objetos, esto es, se puede enfrentar con la realidad de dos modos, a saber, uno teórico y otro práctico. Con base en esto, Kant establece una distinción entre razón teórica y razón práctica, que no son sino dos usos de una y la misma razón. El uso teórico y el uso práctico de la razón son dos usos que $<<$ al fin y al cabo no pueden ser más que una y la misma razón que sólo se distinguen en lo que atañe a su aplicación>>. 19

La razón teórica se enfoca en las condiciones que hacen posible el conocimiento de la naturaleza (entendida como el conjunto de hechos en la experiencia); mientras que la razón práctica se orienta a las condiciones que hacen posible el ejercicio de la libertad (entendida como la autolegislación de la voluntad). ${ }^{20}$ En tanto el uso teórico de la razón busca el conocimiento de la

\footnotetext{
${ }^{17}$ Ibíd., p. 142.

${ }^{18}$ Immanuel Kant, Pedagogía, (Madrid: Akal, 2003), p. 33.

${ }^{19}$ Immanuel Kant, Fundamentación de la metafísica de las costumbres (Madrid: Espasa-Calpe, 1990), p. 50. De acuerdo con Kant, la ciencia filosófica debe investigar por separado sus diferentes objetos, cada cual a partir de sus propios principios racionales, para alcanzar un conocimiento conceptual de los mismos. De ahí que, <<se procede con entera corrección cuando se divide a la filosofía en teórica y práctica〉>. Immanuel Kant, Crítica del discernimiento (Madrid: Antonio Machado Libros, 2003), p. 115.

${ }^{20}<<$ La filosofía se divide [...] según los principios en dos partes totalmente distintas: la teórica, en cuanto filosofía de la naturaleza, y la práctica, en cuanto filosofía moral (pues así se denomina a la legislación práctica de la razón conforme al concepto de libertad)>> Ibíd., p. 116. Así estos diferentes principios del conocimiento (el teórico y el práctico), en tanto se refieren a la posibilidad de sus objetos, únicamente pueden ser asumidos bajo dos clases de conceptos: los conceptos de la naturaleza y el concepto
} 
naturaleza (un conocimiento causal de los hechos), se ocupa del entendimiento, pues éste contiene los principios constitutivos a priori de la capacidad cognoscitiva. ${ }^{21} \mathrm{Y}$ en cuanto el uso práctico de la razón busca el establecimiento de los fines de la libertad, se ocupa de la Razón ${ }^{22}$, ya que ésta contiene los principios constitutivos a priori de la capacidad de desear. ${ }^{23}$

Pero, de acuerdo con Kant, ni la razón teórica ni la razón práctica pueden ofrecer "un conocimiento teórico de su objeto [...] como cosa en sí". Empero, aunque esta idea de una 'cosa en sí' no pueda ser parte del conocimiento (y aunque su mera postulación tampoco pueda ampliarlo), debe ser mantenida indudablemente como posibilidad de todo objeto de experiencia. Tal idea debe ser mantenida a pesar de que constituya un ámbito en el que "no encontramos terreno alguno para nosotros", y en el que ni la razón teórica ni la razón práctica pueden pretender conocimiento alguno:

Hay, por tanto, un campo ilimitado, mas también inaccesible para nuestra capacidad global de conocimiento [...] un campo que [...] hemos de ocupar con Ideas a las que, sin embargo, no podemos procurar otra realidad salvo la realidad práctica relacionada con leyes emanadas del concepto de libertad y en virtud de lo cual nuestro conocimiento teórico no se ve ampliado en lo más mínimo hacia lo suprasensible. ${ }^{24}$

Empleando un lenguaje epistemológico se puede decir que, de acuerdo con Kant, el sujeto posee una capacidad cognoscitiva limitada, por lo que no puede conocer a las cosas en sí mismas, sino sólo se las puede representar como objetos fenoménicos conforme a su entendimiento finito. No obstante, la Razón,

de la libertad. Los conceptos de la naturaleza "hacen posible un conocimiento teórico según principios $a$ priori". Mientras que el concepto de libertad instaura "principios fundamentales que amplían la determinación de la voluntad y [...] por tanto, se llaman prácticos".

${ }^{21}$ La razón teórica contiene, así, principios técnico-prácticos, los cuales ayudan a producir ciertos efectos deseados en la naturaleza a partir del conocimiento de sus causas (por lo que se maneja bajo el principio de causa y efecto).

${ }^{22}$ Kant distingue entre razón como uso (o función) y Razón como facultad (o capacidad).

${ }^{23}$ Así, la razón práctica contiene principios práctico-morales, los cuales ayudan a prescribir los fines propios de la libertad a partir de la propia legislación autónoma de la voluntad (por lo que se maneja bajo el principio del arbitrio).

${ }^{24}$ Ibíd., p. 120. [El subrayado es propio]. 
a diferencia de este último, exige una síntesis incondicionada de lo real, y en tanto la razón teórica no puede ofrecer conceptos que permitan dicha síntesis sin caer en contradicción, la razón práctica ha de llenar este vacío teórico con Ideas. Así, la "solución" de las contradicciones teóricas pretende ser desplazada al dominio práctico postulando las Ideas de la razón, pero éstas no se refieren a un conocimiento de lo incondicionado, sino sólo se les otorga una función puramente regulativa para la vida práctica:

[Las Ideas] son trascendentales para nuestra capacidad teórica de conocimiento, mas no por ello son inútiles o prescindibles, sino que sirven como principios regulativos. ${ }^{25}$

Las Ideas de la razón fungen, así, como Ideas regulativas para la vida práctica, por lo que van más allá del ámbito meramente teorético del entendimiento. Mientras el entendimiento se ocupa del conocimiento teórico mediante conceptos, la razón se ocupa de la prescripción práctica mediante Ideas. Vemos, pues, que las Ideas no surgen sino de la separación entre entendimiento y Razón, entre razón teórica y razón práctica. ${ }^{26}$

Con base en ello, Kant distingue dos formas de legislación, la del entendimiento y la de la razón; aunque ambas tienen escasa influencia la una sobre la otra. Mientras la legislación del entendimiento es teórica y se halla limitada a lo sensible, la de la Razón es práctica y no se encuentra condicionada a lo sensible, sino que descansa en lo suprasensible. ${ }^{27}$ En efecto, la razón teórica permite representarnos (conceptualmente) los objetos dados (sensiblemente) en la intuición, aunque sólo como fenómenos, y no como "cosas

\footnotetext{
${ }^{25}$ Ibíd., p. 110.

${ }^{26}$ Más adelante veremos que en tanto Hegel no efectúa esta separación, no tiene necesidad de postular ninguna Idea que regule la actividad práctica. No tiene necesidad de postular un deber ser.

${ }^{27}$ Véase Immanuel Kant, Ibíd., pp. 120 y ss. <<La legislación mediante conceptos de la naturaleza tiene lugar merced al entendimiento y es teórica. La legislación a través del concepto de libertad la lleva a cabo la razón y es meramente práctica >>. Immanuel Kant, Crítica del discernimiento (Madrid: Antonio Machado Libros, 2003), p. 119.
} 
en sí mismas". 28 Mientras que la razón práctica permite representarnos (inteligiblemente) los fines como Ideas de la razón (suprasensiblemente), pero únicamente como nóumenos, mas no como dados en la experiencia sensible. ${ }^{29}$

En otros términos, mientras la razón teórica trata de describir el ser —la realidad sensible_- la razón práctica trata de prescribir el deber ser —en orden a la realidad suprasensible- (mientras la primera representa el dominio de la necesidad, la segunda representa el dominio de la libertad). Así, de acuerdo con Kant, <<la legislación de la razón humana (filosofía) tiene dos objetos: la naturaleza y la libertad, y por consiguiente abarca tanto la ley natural como también la ley moral [...] La filosofía natural se endereza a todo cuanto es; la filosofía moral, a todo cuanto debe ser >>.30 En tanto la legislación teórica y la práctica se aplican a dominios totalmente distintos, los conceptos de naturaleza (que fundan el conocimiento teórico) y de la libertad (que funda las prescripciones prácticas) no se perjudican entre sí.

Sin embargo, Kant parece sostener que es en la realización efectiva de las Ideas de la razón donde tiene que buscarse la unidad entre lo teórico y lo práctico, entre la naturaleza y la libertad. De este modo, a pesar de que los ámbitos de lo sensible y de lo suprasensible pudieran parecer dos mundos diametralmente distintos, Kant piensa que debe haber una relación entre ellos. Así, "por mucho que se constate un insondable abismo" entre la naturaleza y la libertad, ésta ha de tener algún influjo sobre aquélla:

El concepto de libertad -advierte Kant-debe hacer efectivo en el mundo sensible el fin dado mediante sus leyes y, por consiguiente, la naturaleza también ha de poder pensarse de tal manera que la legalidad de su forma

\footnotetext{
${ }^{28}$ Así, el uso teórico de la razón se encuentra circunscrito a lo sensible, que constituye el dominio hasta donde se pueden aplicar legítimamente los conceptos a priori del entendimiento. En este sentido, el entendimiento es la capacidad cognoscitiva que sólo puede otorgar leyes a la naturaleza.

${ }^{29}$ De este modo, el uso práctico de la razón encuentra su terreno propio en lo suprasensible, donde tiene su aplicación la legislación a priori de la Razón. En este sentido, la razón es la capacidad desiderativa que da leyes (fines morales) a la libertad, y la Razón es la facultad que establece los principios regulativos para la libertad.

${ }^{30}$ Immanuel Kant, Crítica de la razón pura (Buenos Aires: Losada, 2004), p. 774.
} 
concuerde al menos con la posibilidad del fin a realizar en ella según las leyes de la libertad. ${ }^{31}$

Kant plantea la necesidad de pensar una cierta armonía entre las leyes de la naturaleza y las leyes de la libertad. No obstante, como ya se ha dicho, entre el mundo sensible de la naturaleza y el mundo suprasensible de la libertad existe un "enorme abismo", el cual ocasiona que aparezcan como completamente separados, cada uno con sus propias leyes, y no incidiendo el uno sobre el otro:

El concepto de libertad no determina nada con respecto al conocimiento teórico de la naturaleza; ni tampoco el concepto de naturaleza determina nada con respecto a la ley práctica de la libertad; y no es posible tender un puente de un dominio al otro. ${ }^{32}$

Existe aquí una plena separación entre naturaleza y libertad, las cuales se presentan como dos mundos que no sólo están divididos, sino que además se contraponen, uno basado en la razón teórica y otro en la razón práctica. No obstante, a pesar de ello, Kant busca un principio que haga posible una unidad entre teoría y práctica, entre la naturaleza y la libertad, y dicho principio no será sino el discernimiento (el Juicio). De acuerdo con nuestro autor, es el discernimiento el principio que constituye el tránsito de los conceptos de la naturaleza al concepto de la libertad, del uso teórico al uso práctico de la razón:

El discernimiento [es aquello que] suministra el concepto mediador entre los conceptos de la naturaleza y el concepto de libertad, que hace posible

${ }^{31}$ Ibíd., pp. 120-121 [El subrayado es propio]. Aquel fin que no surge sino de la legislación misma de la libertad es la Idea de bien, y es a lo que Kant llamará fin final, el cual debe ser efectivamente realizado en el mundo natural. De ahí que la naturaleza tenga que poder ser pensada de tal forma que dé cabida "al menos" a la posibilidad de realización del bien establecido por la legislación moral. A pesar de que esta Idea de bien juega un papel crucial en la filosofía práctica kantiana, no será tratada en el presente estudio, ya que, debido a su complejidad, dicha Idea merecería un tratamiento por separado.

${ }^{32}$ Ibíd., p. 142. [El subrayado es propio]. 
el tránsito desde la legislación pura teórica hacia la legislación pura práctica. ${ }^{33}$

Es de este modo que, a través del discernimiento, se puede pensar la posibilidad de realizar los fines de la libertad (conforme a sus leyes prácticas) en el mundo natural (conforme a sus leyes teóricas). Sin embargo, Kant nos ha ya advertido que hay un enorme abismo entre el ámbito teórico y el ámbito práctico, y entre los cuales no es posible tender un puente que los unifique, por lo que sólo resta postular ciertas Ideas que vengan a cubrir el vacío dejado por el entendimiento.

Hablando nuevamente en términos epistemológicos podemos decir que, si bien las intuiciones puras de la sensibilidad ordenan las impresiones sensibles espacio-temporalmente, son los conceptos puros del entendimiento los que las ordenan, a su vez, categorialmente constituyendo, con ello, la experiencia. No obstante, el entendimiento cuenta sólo con una cierta estructura categorial que no agota el conocimiento de la experiencia, por lo que habita en ella todavía algo indeterminado, una cosa en sí que le resulta incognoscible al entendimiento humano. La razón, en cambio, busca una síntesis más alta de la experiencia, por lo que no se circunscribe al mundo sensible, sino que se aventura al mundo inteligible donde encuentra las Ideas. Pero tales Ideas no se refieren a la experiencia ni surgen de ella, sino que tienen su origen en la razón y son postuladas como principios regulativos (esto es, normativos) en el terreno práctico:

Así pues, —dice Kant— como el entendimiento necesita de las categorías para la experiencia, la razón contiene en sí la base para las Ideas, por las cuales entiendo conceptos necesarios, cuyo objeto no puede, igualmente,

${ }^{33}$ Ibíd., p. 143. Este "concepto mediador" proporcionado por el discernimiento es el concepto de finalidad de la naturaleza. El discernimiento otorga esta noción de una finalidad en la naturaleza a través del siguiente principio: las leyes empíricas particulares deben ser consideradas como si un entendimiento - no humano - las hubiese reunido en una unidad, de modo que dicha unidad armonice con nuestra capacidad cognoscitiva. Esto es, se debe pensar a la naturaleza como si ésta tuviera una finalidad hacia con nosotros. El principio de 'finalidad de la naturaleza' hace posible entonces el tránsito de la legalidad de la legislación teórica al fin final de la legislación práctica. 
ser dado en experiencia alguna. Las últimas se encuentran en la naturaleza de la razón, igualmente que las primeras en la naturaleza del entendimiento. ${ }^{34}$

Cabe señalar que Kant dice entender las Ideas en un sentido muy próximo al de Platón: las Ideas no se hallan en la experiencia, pues se encuentran más allá de lo sensible e incluso más allá de las categorías que hacen posible la experiencia misma. Es de este modo que, según Kant, Platón empleó ya el término Idea en un sentido similar al suyo, pues <<entendía por él algo que no sólo no se toma nunca de los sentidos sino que además va mucho más allá de los conceptos del entendimiento [...] pues en la experiencia no se halla nunca nada congruente con ese algo $>>{ }^{35}$ De modo que las Ideas no son sino modelos (o prototipos) de los objetos del mundo sensible. ${ }^{36}$ Las Ideas no son algo que surja de la experiencia, pues en ella no se encuentra algo que concuerde con las mismas, sino que emergen de la pura razón. Esto se debe a que, en su actividad de síntesis, la razón se ve empujada más allá del mundo sensible al que se encuentran sujetas las categoría del entendimiento, y se eleva hasta las Ideas (pero al no encontrar aquí ningún asidero firme, la razón se enfrentará a la contradicción, por lo que tendrá que desplazar las Ideas al ámbito práctico).

Pero este impulso de la razón por ir más allá de la experiencia sensible responde a su propia naturaleza cognoscitiva. De acuerdo con Kant, <<tiene la razón humana el singular destino, en cierta especie de conocimientos, de verse agobiada por cuestiones de índole tal que no puede evitarlas, porque su propia naturaleza las impone, y que no puede resolver porque a su alcance no se

\footnotetext{
${ }^{34}$ Immanuel Kant, Prolegómenos a toda metafísica del futuro. Observaciones sobre el sentimiento de lo bello y de los sublime (Buenos Aires: Losada, 2005), p. 116.

${ }_{35}$ Ibíd., p. 429. Según Kant, mientras Platón se ocupa de lo suprasensible, Aristóteles se ocupa, por el contrario, de los conceptos del entendimiento que se refieren al mundo sensible.

${ }^{36}$ De acuerdo con Kant, para Platón <<las Ideas son prototipos de las cosas mismas, y no como las categorías, meras conclusiones para posibles experiencias. En su opinión, provienen de la razón suprema, de la cual se hicieron pasar a la humana, que, sin embargo, ahora ya no se encuentra en su primitivo estado, sino que, con esfuerzo, tiene que evocar de nuevo por reminiscencia (que se llama filosofía) las antiguas Ideas, ahora muy oscurecidas〉>. Immanuel Kant, Crítica de la razón pura (Buenos Aires: Losada, 2004), p. 430.
} 
encuentran >>.37 Según Kant, la razón se ve inclinada naturalmente a formularse ciertas cuestiones a las que es incapaz de responder. La razón se plantea necesariamente determinados problemas a los que no le es posible dar solución. De modo similar:

Platón advertía perfectamente que nuestra facultad de conocer siente una necesidad mucho más elevada que la de limitarse a deletrear meros fenómenos según la unidad sintética para poder leerlos como experiencia, y que nuestra razón, de modo natural, tiende a elevarse a conocimientos que van mucho más lejos para que jamás pueda coincidir con ellos ningún objeto que la experiencia pueda ofrecer, pero que, no obstante, tiene su realidad y en modo alguno son meras quimeras. ${ }^{38}$

Según esto, Platón concebiría que la capacidad cognoscitiva del ser humano se ve inevitablemente llevada, en virtud de su propia naturaleza, a elevarse por encima de la experiencia y alcanzar, con ello, las Ideas; las cuales, a pesar de no contar con un sustento empírico, poseen ciertamente realidad. De este modo, las Ideas no son simples quimeras, sino que cuentan con realidad en tanto objetos de la razón. Su realidad reside en su posibilidad práctica, esto es, en el sentido que tales Ideas otorgan a las acciones en el esfuerzo mismo por su realización. En este sentido, $<<$ Platón hallaba de preferencia sus Ideas en todo cuanto es práctico, es decir, en lo que se basa en la libertad que, a su vez, está bajo conocimientos que son genuinos productos de la razón $>>.39$ De acuerdo con esto, Platón se inclinaba a considerar las Ideas en el orden práctico - fundado en la libertad-, en el que se hallan aquellos objetos que tienen su origen en la mera razón. 40

Consideradas ya dentro del orden práctico, la doctrina platónica le otorga a las Ideas un papel fundamental en el campo político. Recordemos que Platón

\footnotetext{
${ }^{37}$ Ibíd., p. 143.

${ }^{38}$ Ibíd., p. 430.

${ }^{39}$ Loc. cit.

${ }^{40}$ De acuerdo con Kant los Objetos de la razón pura son: la libertad, la inmortalidad del alma y Dios; mientras que para Platón las tres Ideas supremas son; el Bien, la Belleza y la Verdad.
} 
sostenía que para gobernar con justicia, el rey de una república debe participar de las Ideas filosóficas de modo que el rey sea filósofo o el filósofo sea rey. La postulación de esta Idea (de un gobierno basado en el saber filosófico) ha sido ridiculizada por algunos pensadores que la consideran como algo imposible, de tal suerte que, de acuerdo con Kant:

La República platónica se ha hecho proverbial como ejemplo
presuntamente asombroso de soñada perfección que sólo puede caber en
el cerebro del pensador ocioso [...] Pero sería mejor que en vez de dejar a
un lado ese pensamiento, con el misérrimo y nocivo pretexto de su
irrealizabilidad lo estudiáramos más a fondo y con nuevos esfuerzos lo
ilumináramos donde el gran filósofo [Platón] nos haya dejado
desamparados. ${ }^{41}$

Kant piensa que hay quienes consideran la República de Platón como el paradigma de una perfección onírica que surge del ocio del filósofo. ${ }^{42} \mathrm{Si}$ bien Kant acepta que la realización de una Idea tal es imposible, piensa que dicha imposibilidad no es motivo suficiente para abandonarla. Considera que dejar de lado la Idea con base en su irrealización constituye un pretexto mísero e incluso nocivo para la propia filosofía. Kant nos invita a reconsiderar y estudiar en profundidad la Idea de una República perfecta para completarla ahí donde Platón no lo hizo.

Cabe mencionar que recuperando a Platón, lo que Kant pretende es emplear el término de Idea en su sentido originario. ${ }^{43}$ Para ello nos presenta una clasificación de las representaciones que él identifica dentro de su sistema donde ubica el lugar que ocupa precisamente la Idea. En este sentido, la Idea es, según su terminología, <<un concepto a base de nociones, que rebasa la

\footnotetext{
${ }^{41}$ Ibíd., p. 431.

${ }^{42}$ Más adelante veremos que para Hegel la República platónica no consiste en una mera ensoñación que tendría su fuente en la pura ociosidad "especulativa", sino que tal modelo republicano viene, por decirlo de algún modo, a representar el espíritu más elevado de la sociedad griega en la que vivió Platón.

43 Tanto Kant como Hegel pretenden dar una cierta resignificación al término de Idea, pero sin alejarse del todo de su sentido originario, esto es, la Idea entendida como eidos.
} 
posibilidad de la experiencia >>44, pues la Idea no se refiere sino a la perfección de un concepto de la experiencia. Hemos ya apuntado anteriormente que la Idea kantiana denota perfección, la cual, ahora observamos, tiene su origen en ciertas nociones del entendimiento reunidas bajo un concepto de la razón. No obstante, cabe señalar que Kant distingue las Ideas de los ideales, aunque en algunas ocasiones parece emplear estos dos términos como sinónimos.

La Idea contiene la ampliación de toda propiedad esencial perteneciente al concepto (hasta alcanzar su plena concordancia con respecto a sus fines). ${ }^{45}$ Pero el ideal contiene, además, todo aquello que pertenece a la determinación plena de la Idea — que está fuera del concepto mismo-, ya que de todas aquellas determinaciones que se contraponen entre sí, únicamente una de ellas puede corresponder al ideal. ${ }^{46}$ Así, por ideal Kant entiende $<<$ la Idea, no sólo en concreto, sino in individuo, esto es, como cosa individual determinable -o aun determinada- por la Idea exclusivamente >>.47

Kant dice entender por ideal, lo que Platón entendía por Idea del entendimiento divino. Según Kant, la Idea platónica constituye un objeto particular que tiene su fuente en la intuición pura del entendimiento divino. De modo que la Idea representa el ente más perfecto posible y constituye el fundamento originario de todo ente empírico. Aunque Kant no va tan lejos como Platón en afirmar que los objetos de la experiencia representan meras copias de las Ideas inteligibles que los fundan, sí afirma la inteligibilidad y la validez de dichas Ideas. De acuerdo con nuestro autor: <<la razón humana contiene no sólo Ideas, sino también ideales que, si bien no tienen fuerza creadora como los platónicos, sí la tienen práctica (como principios regulativos)

\footnotetext{
${ }^{44}$ Ibid., p. 433.

${ }^{45} \mathrm{Si}$ tenemos, por ejemplo, el concepto de 'saber', la Idea que podemos deducir del mismo es la de 'Sabiduría'.

${ }^{46} \mathrm{Si}$, como hemos dicho en la nota anterior, tenemos el concepto de 'saber' y su Idea es la de 'Sabiduría', podemos deducir de ello el ideal de 'sabio'.

${ }^{47}$ Ibíd., p. 605.
} 
y sirven de fundamento para la posibilidad de la perfección de ciertas acciones $>>.48$

De este modo, además de las Ideas, la razón cuenta con ideales que, al igual que las primeras, poseen fuerza práctica, ya que fungen también como ideas regulativas que guían las acciones hacia la perfección. De acuerdo con Kant, <<estos ideales, aunque no se les quiera conceder realidad objetiva (existencia), no por eso deben considerarse quimeras, sino que proporcionan un criterio indispensable a la razón, la cual necesita el concepto de lo que en su especie es totalmente perfecto para poder apreciar y aquilatar así el grado y los defectos de lo imperfecto $>>.49$

El hecho de que los ideales no existan en la experiencia no los transforma en simples quimeras, pues dichos ideales otorgan un criterio necesario para juzgar las acciones. El ideal contiene una perfección en virtud de la cual se puede comparar y juzgar la experiencia (el mundo presente) y, a partir de ello, tratar de aproximarla a dicha perfección; la cual, sin embargo, jamás puede ser alcanzada plenamente. Aunque el ideal nunca podrá ser alcanzado, su idea de perfección constituye el único criterio que poseemos para juzgar nuestro comportamiento y, así, irlo mejorando (el ideal representa, pues, un prototipo para todas nuestras acciones). Pues la razón requiere de una idea de perfección sobre aquello que juzga para determinar el grado que ha alcanzado y corregir sus defectos para, con ello, acercar lo imperfecto a lo perfecto; esto aunque nunca pueda lograrlo del todo. En este sentido, se puede decir que las carencias e insuficiencias de lo imperfecto sólo son visibles desde lo perfecto.

\footnotetext{
${ }^{48}$ Ibíd., p. 606.

${ }^{49}$ Loc. cit. El ideal no es un producto de la imaginación que carezca de explicación y comprensibilidad, pues aunque no se pueda verificar en la experiencia, el ideal se funda en conceptos determinados. A través del ideal, la razón pretende ofrecer una plena determinación conforme a reglas a priori. En este sentido, la razón concibe a un objeto mediante principios con el fin de determinarle plenamente. No obstante, en tanto en la experiencia se carece de aquellas condiciones suficientes para determinar al objeto completamente, entonces su concepto no puede ser sino trascendente.
} 
El ideal en Kant tiene entonces un doble propósito, por una parte, tiene que servir para juzgar la experiencia con base en su imperfección y, en consecuencia, y esto constituye la otra parte, debe servir de guía a la experiencia aún imperfecta para ir corrigiéndola con miras a esa perfección antes señalada. El sentido del ideal no es sólo contraponerlo a los hechos, sino también indicar el camino para aproximarse al mismo. No obstante, Kant piensa que el <<pretender realizar el ideal en un ejemplo, es decir, en el fenómeno [...] es impracticable y por añadidura encierra algo absurdo y poco edificante, puesto que los límites naturales que continuamente atentan a la perfección de la Idea, hacen imposible toda ilusión en semejante ensayo y con ello llegan aun a hacer sospechoso y semejante a una mera ficción el bien que hay en la Idea $>>.50$

De acuerdo con Kant, no se puede pretender llevar un ideal a la experiencia, ya que ésta, las más de las veces, se opone a la perfección de la Idea en la que se basa el propio ideal. La imperfección de la experiencia hace ver como un sinsentido la realización del ideal (fundado en la idea de perfección), por lo que la ilusión de llevarlo a la práctica se queda en eso, en una mera ilusión. Y en tanto el ideal resulta de hecho impracticable, el afán por darle realidad resulta algo absurdo. El contraste que existe entre lo real y lo ideal hace pasar el bien que contiene su Idea por una mera ficción, e incluso llega a generar recelo hacia este contenido mismo.

Kant piensa que no existe experiencia alguna en la que sea posible hallar las Ideas puestas en concreto, pues <<las Ideas — señala nuestro autor- están más alejadas aún de la realidad objetiva que las categorías [...] Pero más alejado aún que la Idea, parece estarlo de la realidad objetiva aquello que yo

\footnotetext{
${ }^{50}$ Loc. cit. [El subrayado es propio].
} 
denomino ideal >>.51 De este modo, si ya de por sí las Ideas se encuentran alejadas de la realidad concreta, los ideales lo están aún más.

Volviendo, pues, al terreno de las Ideas, que constituye un ámbito más próximo a la realidad que el de los ideales, Kant dice, sin embargo, que ellas contienen una integridad que ningún conocimiento empírico posible puede alcanzar. A pesar de que las Ideas no surjan ni se refieran a la experiencia, ésta ha de tratar de aproximarse a aquéllas. Mediante las Ideas, la razón persigue <<una unidad sistemática a la cual trata de aproximar la unidad empírica posible sin lograrlo jamás del todo>>.52 Pero aunque las Ideas nunca se puedan realizar plenamente en la experiencia, sí pueden guiar la conducta humana. Y aquí reside, según Kant, el gran mérito de las Ideas; mérito que, de acuerdo con nuestro autor, si no es reconocido como tal por la conciencia común, se debe a que ella sigue juzgando la experiencia desde la experiencia misma, esto es, a través de reglas meramente empíricas. No obstante, las Ideas, en tanto principios genuinos de la razón, deben anular la pretendida validez de aquellas reglas sacadas de la mera empiria con las que la conciencia común pretende juzgar la experiencia.

Mientras en el ámbito teórico la experiencia misma otorga un criterio válido para juzgar y legislar sobre la naturaleza; en el ámbito práctico son las Ideas, y no la experiencia, las que otorgan un criterio legítimo para legislar sobre la libertad (que, como se ha dicho, conforma el mundo de la moral). ${ }^{53}$ En el ámbito práctico la experiencia no constituye un principio válido para juzgar las acciones morales, pues ello equivaldría a juzgar el comportamiento moral bajo un criterio causal tal como se juzga la naturaleza (lo cual constituye un equívoco, pues la acción humana, en tanto se funda en la libertad, no puede ser reducida a un comportamiento meramente causal).

\footnotetext{
${ }^{51}$ Ibíd., p. 605.

${ }^{52}$ Loc. cit. [El subrayado es propio].

${ }^{53}$ Anteriormente hemos notado que las legislaciones sobre la naturaleza y la libertad son completamente distintas, pues se basan en dos usos distintos de la razón, el uso teórico y el uso práctico.
} 
De acuerdo con Kant, <<respecto de la naturaleza, la experiencia nos proporciona la regla y es la fuente de la verdad; en cambio, respecto de las leyes morales, la experiencia (por desgracia) es la madre de la ilusión, y es sumamente reprobable que las leyes de lo que debo hacer se tomen de lo que se hace o por ello se pretenda limitarlas $>.{ }^{54}$ Según nuestro autor, en el mundo natural la experiencia es fuente de verdad, mientras que en el mundo moral la experiencia es la fuente de la ilusión, ya que aquí, en la moralidad, lo que es no puede determinar lo que debe ser (hay una clara distinción entre ser y deber ser). En el dominio de la moralidad, lo que de hecho se hace no puede determinar lo que ha de hacerse, puesto que dicho dominio, como se ha señalado, se rige bajo el concepto de libertad, y no así bajo el de causalidad como ocurre en el caso de la naturaleza.

Aquí, se puede observar que, basándose en Hume, Kant distingue con precisión entre el ser y el deber ser: $<<$ confieso con franqueza - dice nuestro autor- que la indicación de David Hume, fue sencillamente la que, muchos años antes, interrumpió mi adormecimiento dogmático [dogmatischen Schlummer] y dio a mis investigaciones en el campo de la filosofía especulativa una dirección completamente distinta >>.55 El reconocimiento al filósofo escocés viene porque supo así distinguir dentro de la experiencia entre lo subjetivo (las ideas) y lo objetivo (lo real); distinción que, en el ámbito práctico, se traduce en una distinción entre el ser y el deber ser. Esto es a lo que se le conoce como la "guillotina de Hume":

En todo sistema de moralidad que hasta el momento he encontrado — dice Hume - siempre he observado que el autor procede, durante algún tiempo, según la forma ordinaria de razonar, y establece la existencia de Dios o hace observaciones concernientes a los asuntos humanos; cuando de pronto me hallo sorprendido de encontrar que, en vez de las cópulas

\footnotetext{
${ }^{54}$ Ibíd., p. 433.

${ }^{55}$ Immanuel Kant, Prolegómenos a toda metafísica del futuro. Observaciones sobre el sentimiento de lo bello y de los sublime (Buenos Aires: Losada, 2005), p. 36.
} 
usuales de las proposiciones, es, y no es, encuentro que no hay ninguna proposición que no se halle vinculada con un debe, o un no debe. Este cambio es imperceptible; pero es, sin embargo, de grandes consecuencias. Pues como este debe, o no debe, expresa una nueva relación o afirmación, es necesario que sea observada y explicada, y que al mismo tiempo deba darse una razón para lo que parece completamente inconcebible: cómo esta nueva relación puede ser deducida de otras, las cuales son totalmente diferentes de ella. ${ }^{56}$

Es sobre esta observación hecha por Hume en el ámbito moral —donde nota el tránsito inadvertido e inválido del ser al deber ser- que Kant le otorga un carácter crítico a la filosofía. En efecto, de acuerdo con nuestro filósofo de Königsberg, la crítica <<es la propedéutica de toda filosofía>>57; y esta actividad crítica consiste justo en establecer los alcances y los límites de la razón misma, en establecer aquello que corresponde a la razón teórica (el ser) y aquello que corresponde a la razón práctica (el deber ser). En este sentido, el papel de las Ideas resulta fundamental en la filosofía kantiana, pues a través de ellas (en tanto contienen la idea de perfección) el filósofo se encargará cuestionar el orden existente (siempre imperfecto), contraponiendo el ser al debe ser.

Con base en la denominada "guillotina de Hume", nuestro filósofo de Königsberg considera que en el ámbito moral es un hecho reprobable el pretender deducir lo que debe ser del mero ser de las cosas. ${ }^{58}$ Para Kant, el

\footnotetext{
$56<<$ In every system of morality, which I have hitherto met with, I have always remark'd, that the author proceeds for some time in the ordinary way of reasoning, and establishes the being of a God, or makes observations concerning human affairs; when of a sudden I am surpriz'd to find, that instead of the usual copulations of propositions, is, and is not, I meet with no proposition that is not connected with an ought, or an ought not. This change is imperceptible; but is, however, of the last consequence. For as this ought, or ought not, expresses some new relation or affirmation, 'tis necessary that it shou'd be observ'd and explain'd; and at the same time that a reason should be given, for what seems altogether inconceivable, how this new relation can be a deduction from others, which are entirely different from it $>$ David Hume, A Treatise of Human Nature (London: Oxford, 1965), p. 469.

${ }^{57}$ Immanuel Kant, Crítica del discernimiento (Madrid: Antonio Machado Libros, 2003), pp. 141-142.

${ }^{58}$ Mientras para Kant "lo que se hace" no puede servir de regla para "lo que debo hacer", más adelante veremos que para Hegel lo que se hace de hecho en la vida ética es lo que determina aquello que he de hacer como ente moral.
} 
deber ser de las acciones morales sólo puede venir dado por las Ideas de la razón. Pero lo mismo que en el caso de la moral, las Ideas determinan el deber ser en el ámbito político, ya que la experiencia de la práctica política no puede determinar lo que se ha de hacer en dicho ámbito. El Estado actual no puede establecer cómo debe ser el Estado perfecto (lo perfecto no puede surgir de lo imperfecto); por el contrario, es la Idea de un Estado perfecto la que debe señalar cómo ha de ser el Estado actual siempre imperfecto. De ahí que, enfocarse en la cuestión de las Ideas constituye, según Kant, "la genuina dignidad de la filosofía".

Pese a ello, de acuerdo con Kant, en el ámbito de la filosofía práctica ha habido un serio descuido de las "genuinas Ideas de la legislación", por lo que no se ha hecho posible organizar el orden estatal conforme a las mismas. De tal suerte que, es principalmente este descuido de las Ideas, y no así la naturaleza humana, lo que representa el primer obstáculo a vencer para organizar el Estado con base en las mismas:

Nada puede haber más nocivo y más indigno de un filósofo — dice Kant— que la plebeya invocación de una presunta experiencia contradictoria, que no habría existido si a su debido tiempo se hubieran adoptado esas instituciones de acuerdo con las Ideas, en vez de burdos conceptos que hicieran fracasar todas las buenas intenciones precisamente porque se sacaron de la experiencia. 59

Según nuestro autor, los conceptos sacados de la experiencia hacen fracasar toda intención, por buena que ésta sea, de organizar al Estado; por lo que la organización estatal debe ser instituida, no conforme a la experiencia de lo que es de hecho en la realidad, sino conforme a lo que debe ser según las Ideas de la razón; las cuales, por cierto, se encuentran al alcance del filósofo. De ahí que si el orden estatal no es instituido conforme a la Idea de un Estado racional (el Estado conforme debe ser), el filósofo no debe lamentarse por ello,

\footnotetext{
${ }^{59}$ Immanuel Kant, Crítica de la razón pura (Buenos Aires: Losada, 2004), pp. 431-432.
} 
ya que fue él quien descuidó aquella Idea de la razón que, de haberla tomado en cuenta, habría posiblemente llevado a buen término la empresa estatal.

Es así que en el ámbito práctico, frente a los conceptos obtenidos de la experiencia, la filosofía debe hacer valer el carácter crítico de las Ideas de la razón para reformar paulatinamente las instituciones políticas. Efectivamente, la filosofía, en tanto actividad reflexiva, ha de mantener una actitud crítica frente a la realidad política, por lo que necesariamente debe plantear una distinción entre lo que ésta es (según conceptos de la experiencia) y lo que debería ser (según Ideas de la razón).

De este modo, aunque Kant intenta hallar una relación entre ambos, establece una clara distinción entre el nivel descriptivo (del ser) y el nivel prescriptivo (del deber ser); distinción que por lo demás le resulta esencial a su sistema filosófico, pues, como hemos dicho ya anteriormente, remite a la distinción básica entre razón teórica y razón práctica. Recordemos que mientras la razón teórica se enfoca a la descripción de la realidad; la razón práctica es capaz de determinar los fines mismos de la acción, esto es, se aboca a prescribir lo que la realidad debe ser para crear las condiciones que garanticen el desarrollo y el ejercicio de la libertad. Condiciones que por cierto, según Kant, sólo son posibles dentro de un Estado justo y, por ende, legítimo.

Kant afirma que a pesar de que históricamente los Estados han surgido del conflicto — de la violencia y el sometimiento60 — la razón nos indica que aquel Estado que pretenda ser legítimo sin más, debe tender a convertirse en un orden social donde reine la virtud, esto es, en un Estado ético (o comunidad ética). ${ }^{61}$ No obstante, desde la misma antropología kantiana, la realización de esta Idea de una comunidad ética es prácticamente imposible:

\footnotetext{
${ }^{60}$ Immanuel Kant, Metafísica de las costumbres (Madrid: Tecnos, 1989), p. 178.

$61<<$ Un estado civil ético es aquel en el que los hombres están unidos bajo leyes no coactivas, esto es: bajo meras leyes de virtud>>. Immanuel Kant, La religión dentro de los límites de la mera razón (Madrid: Alianza, 2001) p. 119.
} 
La Idea elevada, nunca plenamente alcanzable, de una comunidad ética se empequeñece mucho en manos humanas, a saber: para llegar a ser una institución que, capaz en todo caso de representar puramente sólo la forma de aquélla, está, por lo que toca a los medios de erigir un todo semejante, muy restringida bajo condiciones de la naturaleza sensible del hombre. Pero ¿cómo puede esperarse que de un leño tan encorvado sea carpinteado algo plenamente recto? ${ }^{62}$

La Idea de un Estado ético representa la Idea más elevada, el fin último de los seres humanos en el ámbito práctico ${ }^{63}$, ya que en él, el ejercicio libre de la virtud (la búsqueda del deber por el deber mismo), debe posibilitar la felicidad, la cual es un fin en sí mismo (dicho Estado ha de permitir entonces una compatibilidad entre virtud y felicidad). No obstante, antes es necesario instituir un Estado que haga posible la búsqueda de la felicidad misma.

Así, para acceder a un Estado ético Kant postula, justamente como una condición necesaria para su posibilidad, la Idea de un Estado jurídico (o comunidad política) ${ }^{64}$, el cual ha de representar el fin mediato de los seres humanos. Se trata de un Estado de derecho que, mediante la justicia, garantice previamente el igual ejercicio de la libertad, la cual, a su vez, garantice la posibilidad de la felicidad. Por lo demás, dicha justicia solamente es plausible con la división de poderes y bajo un sistema representativo, es decir, dentro de un Estado republicano.

${ }^{62}$ Ibíd., p. 126. [El subrayado es propio]. De acuerdo con Kant, la comunidad ética <<puede también ser llamada Estado ético, esto es: reino de la virtud (del principio bueno), cuya Idea tiene en la Razón humana su realidad perfectamente fundada (como deber de unirse en un Estado tal), aunque subjetivamente no pudiese jamás esperarse de la buena voluntad de los hombres que ellos se decidiesen a trabajar en concordia en orden a ese fin>>. Ibíd., p. 119. Así, no se puede esperar que el ser humano instituya una comunidad ética, pero, como también lo veremos en el caso de la comunidad jurídica, ha de proceder como si pudiese alcanzar algún día tal obra. Ha de mantener la intención en que el reino de Dios (la comunidad ética) se consume en el mundo, esto a pesar de que experiencia parezca denegar toda esperanza de lograrlo.

${ }^{63}$ Una comunidad ética tal viene a representar el "reino de los fines" o el "sumo bien" del ser humano en tanto agente moral.

${ }^{64}$ De acuerdo con Kant, la Idea de una comunidad ética (sociedad civil ética) sólo puede ser llevada a cabo teniendo como base la Idea de una comunidad política (sociedad civil jurídica). V. Loc. cit. Para Kant, <<un estado civil de derecho (político) es la relación de los hombres entre sí en cuanto están comunitariamente bajo leyes de derecho públicas (que son en su totalidad leyes de coacción)>>. Loc. cit. 
De modo que, antes de aspirar al ideal de un Estado ético primeramente es menester aproximarse a la Idea de un Estado jurídico (un orden republicano justo), en el que la soberanía resida, no en el arbitrio de algún particular, sino en la legalidad. Legalidad que, respaldada en la coacción, debe garantizar la libertad de todos (tal Estado debe posibilitar entonces una compatibilidad entre coacción y libertad). Empero, ¿cómo es que resulta pensable la Idea de un Estado justo? De acuerdo con Kant, un Estado puede ser pensado como justo, si es susceptible de ser considerado como si hubiese tenido su origen en un contrato social, ya que solamente un contrato tal contiene las condiciones necesarias de justicia para todos: libertad, igualdad y reciprocidad. Sin embargo, $<<$ en modo alguno es preciso suponer que [este contrato] se trata de un hecho (incluso no es posible suponer tal cosa) [...] Por el contrario, se trata de una mera Idea de la razón>>.65 La figura del contrato social, en tanto Idea de la razón, funge como principio normativo para juzgar la proximidad del Estado real con respecto al Estado racional (un Estado justo que, como hemos visto, ha de representar el fin mediato que debe orientar la actividad política de los seres humanos).

En este sentido, el contrato social sólo simboliza $<<$ el acto por el que el pueblo mismo se constituye como Estado $>>66$, pues representa la $<<$ coalición de cada voluntad particular y privada, dentro de un pueblo, para construir una voluntad comunitaria y pública (con el fin de establecer una legislación, sin más legítima) >>.67 Así, la Idea del contrato social, como principio normativo,

\footnotetext{
${ }^{65}$ Immanuel Kant., Teoría y práctica. En torno al tópico: "Tal vez eso sea correcto en teoría, pero no sirve para la práctica" (Madrid: Tecnos, 1986), pp. 36-37.

${ }^{66}$ Immanuel Kant, Metafísica de las costumbres (Madrid: Tecnos, 1989), p. 145. En tanto este contrato social es tan sólo una Idea (y no algo real), el Estado que se instituye a través de dicho contrato también es considerado como una Idea de la razón. Se trata de un Estado racional cuya legalidad no es deducida sino de la pura razón. En este sentido, <<un Estado (civitas) es la unión de un conjunto de hombres bajo leyes jurídicas. En cuanto éstas, como leyes a priori, son necesarias (no estatuarias), es decir, en cuanto resultan por sí mismas de los conceptos del derecho externo en general, su forma es la de un Estado en general, es decir, el Estado en la Idea, tal como debe ser según los principios jurídicos puros, Estado que sirve de norma [...] a toda unificación efectiva dirigida a formar una comunidad (por lo tanto, en lo interno)>>. Ibíd., p. 142.

${ }^{67}$ Immanuel Kant, Teoría y práctica. En torno al tópico: "Tal vez eso sea correcto en teoría, pero no sirve para la práctica” (Madrid: Tecnos, 1986), p. 36.
} 
sirve para juzgar la legitimidad de la legislación estatal. Sin embargo, de acuerdo con Kant, en tanto la legislación del Estado actual no es siempre necesariamente justa y, en consecuencia, legítima, nunca puede existir una plena adecuación entre el Estado real y el Estado ideal. De ahí que sea menester plantearse, al mismo tiempo, cómo es posible aproximar la realidad a aquella Idea de un Estado justo que la razón ha establecido como fin mediato de la actividad política (y que funge precisamente como condición de posibilidad para el fin último de un Estado ético).

En este sentido, es la misma Idea de contrato social la que permite pensar tal aproximación. En efecto, como principio normativo, el contrato social, además de determinar cómo ha de estar organizado un Estado republicano justo, funge también como un principio pragmático que establece el camino para aproximarse a la Idea de un tal Estado. Efectivamente, la Idea del contrato social <<implica la obligación, por parte del poder constituyente, de adecuar la forma de gobierno a aquella Idea [de un Estado justo], por tanto, si no puede hacerlo de una vez, la obligación de ir cambiándola paulatina y continuamente hasta que concuerde en cuanto a su efecto, con la única constitución legítima, es decir, la de una república pura >>.68 De modo que, la crítica filosófica a la realidad política presente no ha de consistir simplemente en contraponerle la Idea de un Estado justo, sino que es menester tratar de aproximarle a aquella Idea para reducir cada vez más la distancia entre el ser y el deber ser.

\footnotetext{
${ }^{68}$ Immanuel Kant, Metafísica de las costumbres (Madrid: Tecnos, 1989), pp. 178-179. Es en este nivel pragmático donde, al fungir como criterio de legitimidad, la Idea del contrato social encuentra su $<<$ indudable realidad (práctica)〉>, la cual consiste en <<obligar a todo legislador a que dicte sus leyes como si éstas pudieran haber emanado de la voluntad unida de todo un pueblo, y a que considere a cada súbdito, en la medida en que éste quiera ser ciudadano, como si hubiera expresado su acuerdo con una voluntad tal. Pues ahí se halla la piedra de toque de toda ley pública>>. Immanuel Kant, Teoría y práctica. En torno al tópico: "Tal vez eso sea correcto en teoría, pero no sirve para la práctica" (Madrid: Tecnos, 1986), p. 37. Anterior a Kant, el contrato social tenía sólo una función prescriptiva e incluso se le llegó a atribuir "erradamente" una función descriptiva. En cambio, Kant le otorga, además de la prescriptiva, una función pragmática con la que trata de acortar el abismo, derivado principalmente de las transformaciones del mundo moderno, entre lo ideal y lo real. Este nivel pragmático debe cumplir, pues, una función de mediación entre el nivel descriptivo de la realidad y el nivel prescriptivo de la Idea. En este sentido, el contrato social es una Idea con la que se pretende aproximar lo real a otra Idea, a la Idea de un Estado justo.
} 
Se puede observar entonces que en la filosofía práctica de Kant, el orden político actual debe ser reformado con base en la Idea de un contrato social para aproximarlo paulatinamente a la Idea de un Estado justo que precisamente habría surgido de un contrato tal. Esta Idea de un Estado emanado de un contrato social será la que, en última instancia, guiará el sentido de toda reforma institucional. Así, de acuerdo con Kant, la Idea de un Estado organizado bajo <<la máxima libertad humana de acuerdo con leyes que la libertad de cada cual pueda coexistir con la de los demás $>>69$, constituye una "Idea necesaria que debe servir de base" al Estado real, esto es, una Idea en la que se debe fundar toda ley y, en consecuencia, la Constitución del Estado actual. De modo que todo proyecto con miras a establecer un orden estatal debe estar basado en la Idea de un Estado Republicano de libertad.

No obstante, tal como ocurre con la Idea de un Estado ético, Kant reconoce que esta Idea de un Estado republicano "no puede realizarse nunca". Pero, de igual modo, a pesar de su irrealizabilidad, dicha Idea debe servir $<<$ como prototipo para aproximar cada vez más la organización legal de los hombres a la máxima perfección posible >>.70 Y aunque el máximum que levanta esta Idea - el de una República perfecta pura- es prácticamente imposible, no debe sin embargo ser desechada, $<<$ pues cuál sea el grado máximo en que deba detenerse la humanidad, y cuán grande pues el abismo que quede necesariamente entre la idea y su ejecución, son cosas que nadie puede ni debe determinar, precisamente porque es la libertad la que puede rebasar todo límite indicado>>.71 En tanto la implementación de la Idea de un Estado justo corresponde a la libertad, y en tanto ésta es capaz de superar cualquier límite establecido, nadie se encuentra en condiciones de determinar dónde ha de detenerse el ser humano en su esfuerzo por llevar tal Idea a su

\footnotetext{
${ }^{69}$ Immanuel Kant, Crítica de la razón pura (Buenos Aires: Losada, 2004), p. 431.

${ }^{70}$ Ibíd., p. 432.

${ }^{71}$ Loc. cit. [el subrayado es propio].
} 
ejecución en el mundo efectivo, y aunque Kant piensa que nunca sea capaz de cerrar el abismo necesario entre ambos, sí puede reducirlo.

Aquí algunas consideraciones finales. En el presente apartado hemos puesto especial énfasis en el dualismo sostenido por Kant entre teoría y práctica; dualismo del que, pensamos, surgen las Ideas de la razón, las cuales son postuladas como principios normativos que han de guiar la actividad moral y política de los seres humanos. Al parecer siguiendo la advertencia de David Hume de distinguir entre el ser y el deber ser, Kant distingue dos usos de una y la misma razón, uno teórico y otro práctico. Mientras el uso teórico de la razón describe el conocimiento de la naturaleza (del ser), el uso práctico de la razón prescribe el ejercicio de la libertad (el deber ser). Pero, aunque la razón teórica y la razón práctica no han sido declaradas sino como dos usos de una única razón, Kant trata de hallar en el discernimiento (o Juicio) un punto de entronque entre estas dos formas de enfrentarse a la realidad, lo cual constituye una inconsistencia. ${ }^{72}$ Nuestro filósofo trata de unir sin éxito lo que en otro momento había considerado ya como una unidad.

En efecto, una vez establecida esta distinción entre razón teórica y razón práctica, la filosofía kantiana cae un dualismo que no puede superar. Pero Kant piensa que puede lograr una cierta concordancia entre teoría y práctica postulando las Ideas de la razón. Parece entender que es en el esfuerzo por aproximar lo real a lo ideal o llevar lo ideal a lo real, donde la razón teórica y la razón práctica pueden concordar. Pero en tanto su plena unidad resulta imposible, Kant recurre al discernimiento, no ya para unificarles, sino para aproximarles. Es aquí donde actúa el discernimiento para aproximar la realidad a la Idea, el ser al deber ser. Pero a pesar de que Kant pretende

${ }^{72}$ Cfr. Immanuel Kant, Fundamentación de la metafísica de las costumbres (Madrid: Espasa-Calpe, 1990), p. 50. Y también Cfr. Immanuel Kant, Crítica del discernimiento (Madrid: Antonio machado Libros, 2003), p. 143. Efectivamente a pesar de que en el sistema filosófico de Kant, la razón humana se divide en razón teórica y razón práctica, éstas no son sino dos usos de una y la misma razón. Se refieren a un uso teórico y otro práctico de una sola razón, pero después Kant tratará de unirlos como si en realidad se tratara de dos razones incluso contrapuestas. 
reducir la distancia entre el nivel descriptivo del ser (razón teórica) y el nivel prescriptivo del deber ser (razón práctica), mantiene, no obstante, una brecha entre dos ámbitos, naturaleza y libertad, a los que considera irreconciliables.

Con la distinción entre una razón teórica que se ocupa de la naturaleza y una razón práctica que se ocupa de la libertad, Kant pretende otorgarle un carácter crítico a la filosofía donde ser y deber ser no se confundan. Con base en este espíritu crítico, la filosofía kantiana se encargará de establecer de antemano los límites cognoscitivos de la razón y los alcances prácticos de la misma. A partir de un autoexamen libre de la razón, ella misma se encargará de determinar tanto los límites como los alcances legítimos de su propia actividad reflexiva. La razón se erige como su propio tribunal delimitando el uso válido del entendimiento y postulando aquellas Ideas que los seres humanos han de perseguir en tanto agentes racionales. Esto conduce a Kant a mantener necesariamente a una separación normativa: ni la naturaleza se puede conocer completamente, por lo que se postula una "cosa en sí" incognoscible; ni la libertad se puede realizar plenamente, por lo que se postula una "Idea regulativa" irrealizable.

De manera que, por ejemplo, la Idea de un Estado justo debe ser sostenida como aquella "estrella polar" que ha de orientar las acciones y dotarles de sentido. $\mathrm{Y}$ en tanto esta "Idea regulativa" se muestra como necesaria, Kant mantiene todavía un irreductible nivel normativo para su filosofía política, la cual fungirá entonces como una guía para el quehacer humano, pues, mediante las Ideas establecerá cómo debe ser el mundo político presente.

Enseguida veremos la crítica que Hegel dirige a este normativismo kantiano. Recordemos que esta normatividad viene dada por las Ideas de la razón que, en tanto principios regulativos (en tanto contienen la idea de perfección), determinan el deber ser de la vida práctica. Estas Ideas tienen su 
origen en la razón práctica, pero no surgen sino de los límites de la razón teórica. En otras palabras, las Ideas fungen como mediación entre teoría y práctica. Pero en tanto Hegel no parte de una separación entre razón teórica y razón práctica, no tiene la necesidad de postular ciertas Ideas que funjan como mediación entre ambas, ni cierta facultad que trate de unificarles o aproximarles. En la filosofía hegeliana teoría y práctica se hallan unidas, una sólo lo es por la otra: sin práctica no hay teoría, pero sin teoría no hay práctica.

En este sentido, Hegel no le otorgará a la filosofía una función puramente normativa, sino la de concebir la realidad efectiva, esto es, el presente en su necesidad. A diferencia de Kant, la filosofía hegeliana concebirá a las Ideas como algo completamente presente en la realidad, como algo efectivamente realizado, y no como algo fuera del mundo efectivo que habita sólo en la cabeza del filósofo y que, a pesar de que constituya un deber, jamás podrá ser plenamente realizado. Lo que constituye una imposibilidad en la filosofía kantiana, es una necesidad en la hegeliana.

\section{Una crítica de Hegel a Kant}

Hemos visto que Kant le otorga a la filosofía la tarea de prescribir el deber ser de la vida práctica a través de las Ideas de la razón. Pero a partir de doctrinas como kantiana se ha generado, sin embargo, una imagen errónea de la labor filosófica, según la cual, la filosofía tendría como único objetivo postular mundos ideales que se hallan totalmente alejados de la vida efectiva $y$, por tanto, se trata de una reflexión que habita en la mera abstracción. Aunque no deja de ser una tergiversación sobre la filosofía, ésta en ocasiones muestra un desdén por lo concreto para refugiarse en lo abstracto. Pero si alguien ha insistido en acercarse a la vida concreta para pensarle en su efectividad, ese es Hegel. Nuestro filósofo se opone a aquellas filosofías que se retiran del mundo existente y especulan acerca de cómo es que éste debería ser. Es justo a estos 
ideales a los que Hegel les contrapone la categoría de realidad efectiva o efectividad (Wirklichkeit), la cual hace referencia a la necesidad de la filosofía de pensar el mundo en su presente efectivo. Así, de acuerdo con Hegel:

[es importante que la filosofía se entere de que] su contenido es la realidad efectiva. ${ }^{73}$

En contra de aquellas doctrinas que pretenden ocuparse de lo puramente abstracto, de una Idea que se encuentre más allá de la realidad, Hegel piensa que la filosofía ha de pensar lo efectivamente real:

El elemento y contenido de la filosofía no es lo abstracto o lo irreal, sino lo real [das Wirkliche], lo que se pone a sí mismo, lo que está vivo en sí mismo, es decir, la existencia en su concepto [en el concepto de esa existencia]. $^{74}$

El contenido de la filosofía es entonces la realidad efectiva, aquella realidad que ha devenido como lo que es en su propio proceso, y no las abstracciones carentes de realidad que al colocarse como algo puramente ideal pretenden servir de guía a la acción humana. En efecto, para nuestro autor la filosofía no debe ocuparse de la elaboración de un mundo ideal que determine cómo debe ser el mundo presente, sino que ha de pensar lo que efectivamente es, pues $<<$ el nacimiento de la filosofía [...] tiene como punto de partida a la experiencia $>>{ }^{75}$ Pero, si bien el pensamiento parte de la experiencia, no se comporta ante ella de un modo pasivo, sino reflexivo, pues su tarea es justamente subsumir al pensamiento lo que aparece ahí como inmediatamente dado a través de la reflexión. En este sentido, aunque $<<$ la filosofía debe a la experiencia (a lo a posteriori) su primer nacimiento (de hecho), el pensamiento es esencialmente la negación de lo que está ahí inmediatamente >>. ${ }^{76}$ De esta manera Hegel introduce una diferencia entre lo que está ahí dado de inmediato

\footnotetext{
${ }^{73}$ G. W. F. Hegel, Enciclopedia de las ciencias filosóficas (Madrid: Alianza, 1999), p. 105.

${ }^{74}$ G. W. F. Hegel, Fenomenología del espíritu, (Valencia: Pre-textos, 2006), p. 148.

${ }^{75}$ Ibid. p. 113.

${ }^{76}$ Ibíd., p. 115.
} 
(que ciertamente es negado por la actividad del pensamiento) y lo que es pensado como realidad efectiva (que es el resultado entero de la actividad reflexiva). Esta realidad efectiva es la que, según Hegel, constituye propiamente el terreno de la filosofía, ya que es en ella donde tiene lugar la unidad entre ser y pensar, entre el pensamiento (o la Idea) y lo efectivo (o lo real).

No obstante, de acuerdo con Hegel, la conciencia ordinaria, y algunas filosofías que no han logrado desprenderse de ella, siguen manteniendo una separación entre el ser y el pensar, donde el pensamiento y lo efectivo son usualmente contrapuestos de un modo trivial. De ahí que, con frecuencia se oiga decir que aunque no haya nada objetable a la verdad y corrección de un cierto pensamiento, éste no puede, sin embargo, ser encontrado o llevado a cabo en el ámbito de lo efectivo. Empero, para Hegel el sostener esta separación entre el ser y el pensar sólo demuestra que no se ha interpretado adecuadamente la naturaleza tanto del pensamiento como de la efectividad. Puesto que, por una parte, bajo esta perspectiva el pensamiento es considerado como una mera representación subjetiva (como un plan, una intención, etc.); y por otra parte, lo efectivo es considerado como mero ser sensible (como una pura existencia externa disponible a los sentidos).

Tales consideraciones, según Hegel, pueden muy bien ser admitidas en la vida ordinaria, donde no se es muy preciso en el empleo y el significado de las categorías. Bajo esta representación es completamente posible contar con una cierta 'Idea' que, por buena y apropiada que sea, no puede ser encontrada, ni puede ser llevada a cabo en aquello que se denomina 'efectivo' (en el mismo uso ordinario del término). De cualquier forma, cuando el entendimiento abstracto se hace de estas categorías (pensamiento y efectividad) y radicaliza su distinción al punto de considerarlas como una verdadera antítesis (a tal grado que hemos de considerar a las Ideas como algo que reside en nuestra mente y que tenemos que poner fuera de la misma para enfrentarlas con el 
mundo efectivo) entonces es necesario, en nombre de la ciencia y la razón sensata, rechazar determinantemente tal representación del entendimiento. ${ }^{77}$

En la filosofía de Hegel el pensamiento no se contrapone a lo efectivo, las Ideas no se oponen a lo real, como ocurre en la filosofía kantiana, sino que existe una unidad entre el ser y el pensar; y es justo esta unidad a la que se refiere el concepto de realidad efectiva. Enseguida examinaremos más de cerca esta categoría con la que Hegel se enfrentará al idealismo trascendental. La categoría de realidad efectiva aparece en diferentes obras de Hegel, pero su referencia más asistida se encuentra en un par de sentencias que han causado gran revuelo. En efecto, en la "Introducción" a la Enciclopedia de las ciencias filosóficas aparecen las proposiciones: $<<$ Lo que es racional, eso es efectivamente real, y lo que es efectivamente real, eso es racional > 78 (Was vernünftig ist, das ist wirclich, und was wirclich ist, das ist vernünftig). Pero estas proposiciones son mayormente conocidas por su aparición en el "Prefacio" a los Principios de la filosofía del derecho y son a las Hegel nos remite en la Enciclopedia; pero en los Principios, al menos en la versión castellana, aquellas proposiciones aparecen bajo la siguiente forma: $<<$ Lo que es racional es real, y lo que es real es racional $>>.79$

De acuerdo con Hegel "estas proposiciones tan sencillas han parecido escandalosas a muchos", y nosotros podríamos decir que, aún en los tiempos que corren, lo siguen pareciendo. Y si esta sentencia es ya de por sí escandalosa, lo es aún más cuando la realidad efectiva (Wirklichkeit) se traduce por una noción que nos resulta todavía más familiar, esto es, por la noción de realidad (Realität); por lo que nuestro autor se encarga de distinguirlas cuidadosamente. De ahí que en filosofía, dice Hegel, <<es necesario saber, desde el punto de vista formal, que la existencia en general es en parte

${ }^{77}$ G. W. F. Hegel, The Encyclopaedia Logic (Indianapolis-Cambridge: Hackett Publishing Company, 1991), p. 214.

${ }_{78}$ G. W. F. Hegel, Enciclopedia de las ciencias filosóficas (Madrid: Alianza, 1999), p. 106.

${ }^{79}$ G. W. F. Hegel, Principios de la filosofía del derecho (Barcelona: Edhasa, 1999), p. 59. 
fenómeno y solamente en parte es realidad efectiva $>>.80$ En la vida ordinaria se le llama, sin más, realidad efectiva a cualquier existencia "atrofiada y efímera", a "cualquier ocurrencia, al error, al mal" y a todo aquello que pertenece al ámbito de la contingencia; sin embargo, aun desde un entendimiento ordinario, lo contingente - aquello que existe por mera casualidad- no merece ser nombrado como realidad efectiva, sino como mero fenómeno. Según nuestro filósofo, si se considera con agudeza al mundo (aquel amplio campo de lo existente), se verá que se puede distinguir entre lo meramente fenoménico que es contingente- y lo realmente efectivo — que, como se observará más adelante, es necesario- - De modo que no todo lo existente merece el nombre de realidad efectiva. De acuerdo con esto, si se reflexiona sobre el mundo se verá que no todo lo real es realmente efectivo.

Hegel aclara entonces que cuando emplea la expresión "realidad efectiva”, lo hace en un sentido muy específico, pues su contenido es otro del que generalmente se le atribuye. Este sentido específico de la realidad efectiva es principalmente tratado por Hegel en la Ciencia de la lógica, donde le distingue con precisión de lo contingente, lo cual $<<$ es una existencia que no tiene más valor que el de una posibilidad, algo que tanto es como podría igualmente no ser $>.81$ Mientras que, como ya se ha mencionado, la realidad efectiva tiene que ver, no con la contingencia, sino con la necesidad. No obstante, es de gran importancia señalar desde ahora que, de acuerdo con Hegel, lo contingente "ciertamente existe" (no es una mera ilusión); y en cuanto realmente se trata de "una existencia", la contingencia hace ver que no todo es necesario. La filosofía hegeliana no enaltece la necesidad de todo cuanto existe, como comúnmente se piensa. De modo que, al distinguir con precisión la realidad efectiva de lo contingente, Hegel también la distingue de lo simplemente existente.

\footnotetext{
${ }^{80}$ G. W. F. Hegel, Enciclopedia de las ciencias filosóficas (Madrid: Alianza, 1999), p. 106.

${ }^{81}$ Ibíd., pp. 106-107.
} 
Si la noción de realidad efectiva, que como hemos visto es completamente racional, se identificara con lo existente, se estaría favoreciendo una interpretación que dignificaría lo meramente real al nivel de lo racional. Pero con ello Hegel estaría santificando al mundo existente, y el pensamiento especulativo se complacería con lo que es (con lo que existe). Pero el que la filosofía tenga como contenido la realidad efectiva significa que el pensamiento filosófico no se satisface con la realidad sin más (Realität), sino que justo tiene por objeto pensar la realidad como algo efectivo (Wirklichkeit) ${ }^{82}$, como algo racional. Aunque Hegel distingue entre realidad y realidad efectiva, sobran quienes pasan por encima de esta distinción y piensan que en la filosofía hegeliana todo lo que existe, por el mero hecho de existir, es ya racional.

Lo problemático de este asunto está directamente relacionado con la compresión de las proposiciones que afirman la efectividad de todo lo racional, y la racionalidad de todo lo efectivo; proposiciones que, además de resultar escandalosas, "se han ganado enemigos" por parte de quienes piensan estar en posesión de la filosofía. ${ }^{83}$ Pero tales proposiciones pueden alcanzar una mayor claridad si se las compara con aquellas representaciones a las que parecen oponerse. De acuerdo con Hegel, la realidad efectiva de lo racional (esto es, el que lo racional sea efectivo) se opone por una parte a $<<$ la representación de que las Ideas y lo ideal no son más que quimeras y que la filosofía no es más que un sistema de telarañas mentales $>>$. Pero por otra parte, esta efectividad de lo racional también se opone a $<<$ la representación de que las Ideas y lo ideal son cosa demasiado exquisita para alcanzar realidad efectiva, o también demasiado impotente para conseguírsela>>.84

${ }^{82} \mathrm{Y}$ de acuerdo con Hegel la conciencia de esta realidad efectiva es lo que se puede denominar propiamente experiencia en sentido filosófico.

${ }^{83}$ Cabe señalar que para Hegel la filosofía es una forma de hacer consciente la realidad efectiva; de acuerdo con esta forma, la filosofía se distingue de otros modos de aprehender lo realmente efectivo, como la religión.

${ }^{84}$ Ibíd., p. 107. 
Aquí, en esta segunda oposición, Hegel se enfrenta principalmente a la filosofía kantiana, a la que considera como una doctrina del entendimiento, y no de la razón, pues mantiene una escisión entre la Idea y la realidad. Recordemos que en el terreno práctico, Kant se basa en la formulación de ciertos principios a los que les asigna el papel de Ideas regulativas que, sin embargo, no alcanzan ninguna realidad concreta. De ahí que, para el entendimiento toda Idea permanezca simplemente como un deber inalcanzable y al que sólo resta aproximarse. En este sentido, al toparse con la Idea, la pereza del entendimiento, dice Hegel, toma la salida fácil del deber ser, con lo que mantiene una separación entre el ser (realidad) y el pensar (Ideas). De esta manera, la realización efectiva de la Idea, es decir, su realidad efectiva, no tiene lugar. Pues algo que solamente debe ser, no puede tener, por consiguiente, realidad alguna. De modo que:

A quien le es especialmente querida la separación entre realidad efectiva e Idea es al entendimiento que tiene por verdaderos los sueños de su abstracción y se envanece con el deber [moral] que él receta muy agusto especialmente en el terreno político. ${ }^{85}$

En este sentido, el entendimiento se comporta $<<$ como si el mundo hubiese tenido que aguardarle a él para saber cómo debe ser, sin serlo; porque si el mundo fuese ya como debe ser, ¿qué lugar habría para la precoz sabihondez de su deber ser?>>. Pero además, dice Hegel, <<¿quién no es lo suficientemente listo para ver en torno a sí muchas cosas que no son de hecho como deberían ser?>>.86

El entendimiento realiza una separación entre el ser y el pensar, y se complace con sus Ideas abstractas a las que les otorga el lugar de un "deber ser", las postula como principio regulativos que deben guiar el quehacer humano, en especial la actividad política. No obstante, el mundo político ya es

\footnotetext{
${ }^{85}$ Loc. cit.

${ }^{86}$ Loc. cit. [El subrayado es propio].
} 
como es sin la necesidad de esperar a que el entendimiento le indique desde el exterior cómo es que ha de ser; e incluso sin el auxilio de este "sabio" entendimiento, que cree poseer el saber exclusivo de cómo debe ser el mundo, la conciencia común puede ya observar que lo que es, no siempre es como debería ser.

Con todo, puede ser que el entendimiento tenga razón cuando, basado en el deber ser, acomete contra aquellos objetos "triviales, extrínsecos y caducos", o contra aquellas "cosas establecidas o situaciones" que - por determinado tiempo y para determinados ámbitos - tal vez puedan contar con una importancia sólo relativa. Y puede ser que con ello el entendimiento "encuentre muchas cosas que no se corresponden con determinaciones universales y justas", y por ello sean inesenciales, esto es, contingentes.

Pero aunque el entendimiento pueda tener razón en arremeter contra lo contingente, no la tiene, sin embargo, al pensar que con este mero ataque se coloca ya dentro de la ciencia filosófica. El que, basado en la "sabihondez" de su deber ser, el entendimiento critique esos objetos contingentes como algo obsoleto, no le pone ya en el camino de la ciencia, pues $<<$ la ciencia filosófica se ocupa de una realidad efectiva frente a la cual aquellos objetos, esas cosas establecidas y situaciones sólo son apariencia externa o superficial $>>$. La ciencia filosófica $<<$ trata solamente de la Idea, la cual no es tan impotente que se limite a ser un deber sin realización efectiva >>.87 A diferencia de Kant, para Hegel las Ideas no están meramente colocadas en nuestras cabezas, y no son algo tan impotente que su realización (o no) dependa de nuestra mera voluntad; por el contrario, la Idea es a la vez algo real y efectivo. ${ }^{88}$ Como hemos visto, las Ideas no son ni algo demasiado exquisito, ni algo demasiado impotente como para no alcanzar realidad, no son meras quimeras (donde la filosofía, que se

\footnotetext{
${ }^{87}$ Loc. cit. [El subrayado es propio].

${ }^{88}<<$ [The] ideas are not just to be found in our heads, and the Idea is not at all something so impotent that whether it is realised or not depends upon our own sweet will; on the contrary, it is at once what is quite simply effective and actual as well >. G. W. F. Hegel, The Encyclopaedia Logic (Indianapolis-Cambridge: Hackett Publishing Company, 1991), p. 214.
} 
ocupa de ellas, vendría a ser una simple maraña mental); al contrario, las Ideas son lo más real que hay.

En la filosofía kantiana, en tanto las Ideas constituyen tan sólo postulados de la razón, no son algo realmente efectivo. En Kant las Ideas no surgen de la experiencia ni pueden ser aplicadas plenamente a ella, sino que surgen de la legislación de la razón práctica con una función puramente regulativa. De modo que, aunque exista una obligación (basada en el deber moral de libertad) para la realización tales Ideas, éstas nunca se llevarán a cabo de forma plena en el mundo efectivo. ${ }^{89}$ Así, a pesar de que Kant pretende la realización de la Idea en lo real (es decir, una unidad entre el ser y el deber ser), únicamente se queda en la mera pretensión, pues sostiene un dualismo irrevocable:

En todo sistema dualístico — dice Hegel—, y muy particularmente en el kantiano, su defecto fundamental se da a conocer por la inconsecuencia de unir lo que en un momento antes se ha declarado autosuficiente y, por tanto, imposible de unir. ${ }^{90}$

Frente a una unidad originaria entre la Idea (el pensamiento) y lo real (el ser) sostenida por la filosofía hegeliana, Kant sostiene una dualidad entre ambos, a los que declara como autosubsistentes. Así, antes que una unidad originaria, la filosofía kantiana se enfoca en una realidad meramente sensible a la que pretende unir o, mejor dicho, aproximar a una Idea puramente inteligible. De modo que no hay en ella una plena armonía entre el pensamiento y la realidad, es más: <<en contra de esta armonía, se suscita de nuevo y se afirma aquella oposición que ha sido puesta como no verdadera en su contenido, de tal modo que la armonía se determina como algo meramente

${ }^{89}$ La formulación misma de la Idea contiene ya la exigencia de realizarla en el mundo, su universalización se refiere ya a una necesidad de plasmarla en lo concreto; pues de otro modo no requeriría de universalización, y bien podría conformarse con un contenido particular. Pero en tanto la Idea no tiene su origen sino en la pura subjetividad de un pensamiento que considera a la razón como algo ahistórico, ella misma no alcanza realidad, se mantiene como un puro deber.

${ }^{90}$ G. W. F. Hegel, Enciclopedia de las ciencias filosóficas (Madrid: Alianza, 1999), p. 162. 
subjetivo (algo tal que solamente debe ser, es decir, que al mismo tiempo no tiene realidad $>>.91$

De ahí que, de acuerdo con Hegel, en Kant la unidad de lo sensible y lo inteligible no tiene verdad objetiva, sino simplemente "certeza subjetiva". Así, en la filosofía kantiana aquella armonía entre lo ideal y lo real $<<$ [se determina] como algo creído a lo que sólo le conviene certeza subjetiva y no verdad, es decir, algo a lo que no se le atribuye aquella objetividad que le correspondería a la Idea >>.92 De este modo, se puede observar nuevamente que mientras para Hegel la Idea tiene presencia efectiva, para Kant se mantiene como aquello que debería tener presencia, como algo que tendría que ser realizado efectivamente, pero que aún no lo es (e incluso, por definición, nunca lo será plenamente).

Así, la Idea kantiana misma parece encerrar una contradicción, pues por una parte, su propia formulación contiene ya la exigencia de su realización efectiva; pero por otra parte, en tanto principio regulativo, contiene la imposibilidad de su plena realización en el presente, pues ha de ser mantenida como un deber ser que guíe las acciones humanas. Pero:

Cuando esta contradicción parece haber sido disimulada desplazando hacia el futuro la realización de la Idea en el tiempo, futuro en el que la Idea también sería, resulta entonces que esta condición sensible, como lo es el tiempo, es más bien lo contrario de una solución de la contradicción, [porque] la representación de entendimiento que le corresponde es la de progreso sin término, lo cual es inmediatamente nada más que la misma contradicción que ya fue [anteriormente] puesta, perpetuándose continuamente. ${ }^{93}$

\footnotetext{
${ }^{91}$ Loc. cit.

${ }^{92}$ Loc. cit.

${ }^{93}$ Loc. cit.
} 
Esta contradicción entre la exigencia de la realización de la Idea y la imposibilidad de la misma en el mundo efectivo, es lo que lleva a Kant a postularla sólo como un principio regulativo, como un puro deber ser ${ }^{94} \mathrm{En}$ efecto, de acuerdo con Hegel, en la filosofía kantiana esta contradicción pretende pasar inadvertida postergando la realización de la Idea a un tiempo indefinido, pero lejos de constituir una solución, su prolongación en el tiempo hace más clara la contradicción. Según nuestro autor, es la "pereza del entendimiento" la que al hallar la Idea, toma la fácil resolución de postularla como un deber ser para no comprometerse con la realización de la misma en el mundo efectivo.

Si la Idea se promueve como algo que debe ser realizado, pero que en realidad (en tanto deber ser) nunca se realiza, ni debe serlo, entonces se ha de postular una aproximación infinita a la misma. Y esta progresión indefinida hacia la Idea, no hace sino hacer explícita la contradicción — que ahora se muestra continuamente en el tiempo- entre dicha Idea y el mundo real. De cualquier manera, la contradicción inicial se mantiene, sólo que ahora se manifiesta a cada momento... cada vez que se constata la ausencia de la Idea en el mundo efectivo. La imposibilidad de realizar la Idea no hace sino confirmar la constante contradicción en el tiempo entre lo ideal y lo real; por lo que, aquello que trata de disimular la contradicción, la hace evidente a cada instante. Así, aunque Kant intenta dar solución a esta aporía, parece que sólo la prolonga.

La filosofía kantiana sostiene, pues, que pesar de que en el presente la Idea no es todavía realizada, es completamente pensable que en un tiempo futuro se realice (pues no hay contradicción alguna en ello); pero aunque su realización sea completamente pensable, ésta nunca se alcanzará plenamente, pues la Idea es declarada como algo meramente posible y, con ello, se ve

\footnotetext{
${ }^{94}$ Se puede observar que es con las Ideas de la razón que Kant intenta salvar el abismo infranqueable (Übersehbar) que mantiene separados al mundo sensible y al mundo inteligible, pero en tanto se trata de dos órdenes inconmensurables, dichas Ideas son postuladas como un mero deber ser.
} 
condenada a su imposibilidad. Lo único que resta entonces es sólo un acercamiento infinito. Pero ante esta separación kantiana entre lo ideal y lo real, Hegel insiste en concebir a la Idea como algo ya realizado en la realidad, como algo completamente presente en el mundo efectivo.

Para ello Hegel acude a un principio del empirismo de acuerdo con el cual $<<$ lo que es verdadero tiene que estar en la realidad efectiva y ahí tiene que estar [disponible] para la percepción. Este principio es contrapuesto al deber ser con el cual se hincha [la filosofía de] la reflexión y desprestigia la realidad efectiva y el presente valiéndose de un más allá que no puede tener otro asiento y existencia que el entendimiento subjetivo $>>$. Hegel se remite entonces a la verdad del mundo efectivo, a la experiencia efectiva de la Idea en el mundo presente, la cual se contrapone a los ideales del entendimiento subjetivo que se sitúan más allá de la experiencia (a la que desprestigian) y, con ello, permanecen como un mero deber ser que surge de la pura subjetividad, y no del pensamiento filosófico propiamente dicho:

Tal como hace el empirismo, la filosofía sólo conoce lo que es, lo que meramente debe ser y por ello no está ahí, eso, la filosofía no lo sabe..$^{95}$

La filosofía sólo se ocupa de lo que realmente es, y no de lo que debería ser, pues de ello nada sabe; su objetivo es conocer lo que es como realidad efectiva. La actividad filosófica consiste justo en llevar lo existente a realidad efectiva. En Hegel la categoría de realidad efectiva hace referencia a que lo ideal (lo racionalmente constituido) encuentra presencia efectiva en el mundo, y a que lo real (lo constituido racionalmente) no es sino pensamiento hecho mundo. Así, el que la filosofía lleve lo existente a ser comprendido como realidad efectiva, significa que tal existencia ha de ser comprendida como la unidad de lo real y lo ideal, de ser y pensar. De esta manera, la filosofía debe transformar, mediante el proceso reflexivo, a la experiencia en realidad efectiva para constituirla como la unidad de ser y pensar, la cual constituye su verdad.

\footnotetext{
${ }^{95}$ G. W. F. Hegel, Enciclopedia de las ciencias filosóficas (Madrid: Alianza, 1999), p. 140.
} 
Así, el fin último de la ciencia filosófica consiste en generar una reconciliación entre el ser y el pensar, entre el ser que piensa y el ser pensado... y sólo eso es realidad efectiva.

Lo meramente real no es entonces de modo inmediato algo realmente efectivo. Sin duda habitamos una realidad, pero la realidad efectiva no es cualquier realidad, sino aquella que es completamente racional. La realidad efectiva se refiere a <<aquel haber que [fue] originariamente producido y [continuamente] se produce en el campo del espíritu viviente; haber que se ha hecho mundo, mundo exterior y [mundo] interior de la conciencia>>.96 En otras palabras, lo realmente efectivo es aquella realidad que ha sido completamente aprehendida por la autoconsciencia como la unidad de lo interno y lo externo (o la unidad de lo que Hegel llama forma y contenido); unidad en la que la realidad se hace pensamiento, y el pensamiento se hace realidad.

De este modo, para nuestro autor, la realidad efectiva no es tan mala o irracional como imaginan aquellos "hombres prácticos" que están faltos de pensamientos o cuyo pensar e intelecto es débil. La realidad efectiva, en contraste con la mera apariencia, está lejos de ser algo opuesto a la razón o algo distinto de ella; la realidad efectiva es, por el contrario, aquello que es racional de pies a cabeza. De ahí que aquello que no es racional, por ese mismo motivo, no debe ser considerado como algo realmente efectivo. ${ }^{97}$ De acuerdo con Hegel, en el uso del lenguaje culto (gebildete Sprachgebrauch) se puede encontrar ya esta concepción de la realidad efectiva, puesto que tal lenguaje se niega, por ejemplo, a considerar como realmente efectivo a un poeta o a un hombre de Estado (Staatsmann) que no puede hacer nada realmente meritorio y razonable; en este sentido, un poeta efectivo o un hombre de Estado efectivo es,

\footnotetext{
${ }^{96}$ Ibíd., p. 105.

$97<<$ Actuality is not so bad or so irrational as it is imagined to be by "practical men" who are devoid of thoughts or at odds with thinking and intellectually derelict. As distinct from mere appearance, actuality [...] is so far from confronting reason as something other than it, that it is, on the contrary, what is rational through and through; and what is not rational must, for that very reason, be considered not to be actual >>. G. W. F. Hegel, The Encyclopaedia Logic (Indianapolis-Cambridge: Hackett Publishing Company, 1991), p. 214.
} 
por tanto, sólo aquel que es capaz de producir algo válido y racional. No obstante, como ya se ha dicho, en la vida ordinaria la consciencia común confunde la realidad efectiva con lo meramente real, y en tanto esta confusión trae consigo grandes equívocos con respecto al objeto de la filosofía, nuestro autor insiste en diferenciarlos con claridad.

Hegel piensa que la distinción entre lo real —aquello que es tangible e inmediatamente perceptible- y lo realmente efectivo -aquello que es constituido completamente por la razón-, puede ser dilucidada remitiéndose a las diferencias que mantienen entre sí las filosofías de Platón y Aristóteles. De acuerdo con nuestro autor, existe un prejuicio generalizado según el cual la diferencia fundamental entre estas dos filosofías consiste en que mientras Platón reconoce la Idea y sólo la Idea como lo que es verdadero, Aristóteles, por el contrario, la rechaza como algo independiente y se atiene a lo que es efectivo (de ahí que, se dice, deba ser considerado como el fundador y el líder del empirismo). Pero, para Hegel, aquí no puede residir la diferencia entre estas dos filosofías, pues si bien es cierto que lo efectivo constituye el principio de la filosofía aristotélica, no se trata de un efectivo en el sentido ordinario del término, es decir, de aquello que está inmediatamente presente, sino de una efectividad que es tal por la realización de la Idea. De este modo, frente a Platón, Aristóteles considera a la Idea como algo en sí mismo efectivo. Por tanto:

La controversia de Aristóteles contra Platón consiste, con mayor precisión, en la denominación de la Idea platónica como mera dynamis, y en la urgencia, por el contrario, de que la Idea, la cual es reconocida igualmente por ambos como lo único verdadero, debe ser considerada esencialmente como energeia, por tanto, como lo interior que es totalmente lo exterior [heraus], esto es, como la unidad de lo interno y lo 
externo. En otras palabras, la Idea debe ser considerada como Efectividad en el sentido enfático que le hemos dado aquí. ${ }^{98}$

Según esto, Aristóteles consideraría la Idea platónica como mera dynamis (en potencia), y plantearía la exigencia de considerarla como energeia (en acto), esto es, como el pensamiento realizándose en la realidad. De modo que, la Idea ha de ser considerada como realidad efectiva, es decir, como la unidad de lo interno y lo externo (como lo interior que es exterior, y lo exterior que es interior). En contra de su maestro, el Estagirita sostiene que la "forma" es inmanente a la "materia". Así, de acuerdo con Hegel, Aristóteles tiene el mérito de haber caracterizado al mundo sensible también como inteligible, y no como algo meramente externo.

Si la forma (lo inteligible) no se realiza en la materia (lo sensible), entonces sólo permanece en potencia; pero si, por el contrario, la materia no se muestra sino como la manifestación de la forma, entonces ésta existe en acto (en este sentido, mientras que la Idea platónica se queda en potencia, la aristotélica se concreta en acto). De este modo, se presenta un paralelo entre la noción de actividad en Aristóteles y la categoría de efectividad en Hegel en la medida en que ambas categorías no expresan sino la realización de la forma (Idea) en la materia (realidad). ${ }^{99} \mathrm{El}$ especial interés que Hegel mantiene en Aristóteles se debe a que éste va más allá de Platón al considerar que el pensamiento se encuentra efectivamente en acto, y no sólo en potencia como la Idea platónica; del mismo modo que Hegel piensa ir más allá de Kant al

$98<<$ More precisely, therefore, Aristotle's polemic against Plato consists in his designation of the Platonic Idea as mere dynamis, and in urging, on the contrary, that the Idea, which is recognised by both of them equally to be what is alone true, should be regarded essentially as energeia, i. e., as the inwardness that is totally to the fore; so that it is the unity of inward and outward. In other words, the Idea should be regarded as Actuality in the emphatic sense that we have given to it here >. G. W. F. Hegel, The Encyclopaedia Logic (Cambrige: Hackett Publishing Company, 1999), p. 215.

${ }^{99}$ No obstante, existe una diferencia fundamental entre ambas nociones. Aunque para Aristóteles aquello que existe en acto es la plena realización de la forma (lo inteligible) en la materia (lo sensible), considera a esta última como algo inmediatamente dado. La materia aparece como algo subsistente de suyo e independiente del pensamiento, al cual sólo le resta determinarle, por lo que parece quedar confinado a los límites de lo sensible. En cambio, la efectividad en Hegel se esfuerza por mostrar que las determinaciones del objeto no son sino determinaciones del pensamiento, las cuales son paulatinamente generadas por la confrontación entre la multiplicidad inmediata y la unidad reflexiva. 
plantear que el pensamiento se halla efectivamente en lo real, y no es un principio meramente regulativo como la Idea kantiana. ${ }^{100}$ Así, al hablar de realidad efectiva, Hegel parece remitirse a la unidad aristotélica de forma y materia, pero intenta reformularla a partir de la unidad kantiana entre lo sensible y lo inteligible. ${ }^{101}$

Ciertamente Aristóteles criticó a Platón por la separación que éste realizó entre el mundo sensible y el mundo de las Ideas ${ }^{102}$, aunque le reconoció el hacer participar a las cosas sensibles de tales Ideas. Así, del mismo modo en que resulta equivocado decir que Aristóteles se atiene a lo puramente sensible, resulta igualmente erróneo decir que Platón se aboca a lo meramente inteligible. Hegel considera, pues, que diferenciar la doctrina aristotélica de la platónica con base en la distinción entre lo sensible y lo inteligible sólo constituye un extendido prejuicio dentro de la tradición filosófica: <<Es, [...] una opinión muy generalizada la de que la filosofía aristotélica y la platónica se enfrentan y se oponen la una a la otra, concibiéndose ésta como basada en el idealismo y aquélla, por el contrario, como construida sobre el realismo, el realismo más trillado y trivial $>>.103$

De este modo, según nuestro autor, ni Aristóteles permanece en lo puramente efectivo, ni Platón se mantiene en lo meramente ideal. En efecto,

${ }^{100}$ Así al introducir su noción de efectividad, Hegel se refiere a Aristóteles porque en la polémica que éste sostiene contra Platón, parece ocupar la posición que Hegel mismo pretende ocupar en su polémica contra Kant.

${ }^{101}$ Hegel se interesa en Aristóteles en tanto ve en este último el intento por unificar "forma" y "materia", lo que en términos modernos podría traducirse como el intento por superar la oposición entre lo sensible y lo inteligible, y poner fin a la separación epistemológica que domina al mundo moderno.

${ }^{102}$ En la Metafísica, Aristóteles dice que <<[...] ocupándose Sócrates de los problemas morales y no de la Naturaleza en su conjunto, pero buscando en ellos lo universal, y habiendo sido el primero que aplicó el pensamiento a las definiciones, Platón aceptó sus enseñanzas, pero por aquel motivo pensó que esto se producía en otras cosas, y no en las sensibles; pues le parecía imposible que la definición común fuese de alguna de las cosas sensibles, al menos sujetas al perpetuo cambio. Este, pues, llamó a tales entes Ideas, añadiendo que las cosas sensibles están fuera de estas, pero según estas se denominan todas >. Metafísica, A 987 a 29-b 14. Más adelante, Aristóteles continúa: <<Y así pensaban (los partidarios de las Ideas) que, entre las cosas sensibles, las singulares fluían sin que nada de ellas permaneciera, y que lo universal existía fuera de ellas y era otra cosa. Y esto, como ya hemos dicho, lo inició Sócrates con sus definiciones, aunque ciertamente no separó los universales de los singulares. Y estuvo acertado al no separarlos >. Metafísica, M 1086 a 37-b 5.

${ }^{103}$ G. W. F. Hegel, Lecciones sobre la historia de la filosofía II (México: FCE, 1955), pp. 238-239. 
contrariamente a Kant, Hegel piensa que la doctrina platónica de la Ideas no hace referencia a un mundo más allá de lo sensible, pues $<<$ mediante la exposición de sus Ideas, Platón puso al descubierto el mundo intelectual, pero sin ver en él un mundo situado más allá de la realidad, en el cielo, en un lugar distinto, sino el mundo real, del mismo modo que Leucipo había acercado lo ideal a la realidad, sin colocarlo -metafísicamente- detrás de la naturaleza>>.104 De acuerdo con Hegel, lo esencial de la teoría platónica de las Ideas debe buscarse en la concepción según la cual lo verdadero es el intelecto, y no aquello que está dado inmediatamente a nuestra sensibilidad. La verdad del mundo sensible, en cuanto sólo es como ser determinado por el pensamiento, reside en el mundo intelectual de las Ideas; que, según nuestro autor, es lo único digno de ser conocido, lo único que es en y para sí.

No obstante, a pesar de ello, para Hegel la teoría de las Ideas en Platón ha sido tergiversada, al menos, en dos formas. La primera tergiversación es aquella del pensamiento formal que considera la realidad sensible (aquello que se representa mediante los sentidos) como la verdadera realidad y considera a las Ideas, en cambio, como algo perteneciente sólo a nuestro pensamiento, o bien como una esencia (o sustancia) trascendente situada más allá de lo real y del pensar; la segunda tergiversación consiste en considerar a las Ideas como aquello que carece actualmente de realidad, y que nunca podrán sea plasmadas en la misma, por lo que son consideradas como meros ideales necesarios de la razón. Así, mientras que en la primera tergiversación las Ideas se hallan en un más allá que se representa como un intelecto fuera o al margen del mundo físico; en la segunda, las Ideas se encuentran en un más allá, el cual podría considerarse como un más acá, que viene representado por la razón. Aquí Hegel parece estarse refiriendo a la interpretación que hace Kant de las Ideas platónicas.

\footnotetext{
${ }^{104}$ Ibíd., p. 160.
} 
Frente a la doctrina kantiana y algunas otras interpretaciones, Hegel piensa que las Ideas platónicas no se encuentran en un más allá o en otra vida, sino que se hallan en la realidad, pero en la realidad considerada en su verdad, y no en aquella que se ofrece a la mera sensibilidad. Así, por ejemplo, el contenido real de la República platónica no es sino la vida verdadera del Estado griego, su Idea de un orden político republicano muestra el mundo ético griego en su verdad sustancial. De modo que, de acuerdo con Hegel, <<incluso la república platónica, que proverbialmente se considera como un ideal vacio, no hace en esencia más que captar la naturaleza de la eticidad griega >>.105 Platón supo reconocer y exponer en su República el espíritu verdadero de su tiempo: la verdad del mundo en el que vivió (y tal espíritu se hallaba igualmente vivo tanto en Grecia como en el mismo Platón).

A partir de una situación insatisfactoria en el Estado griego, Platón buscó poner fin a la misma mediante la postulación de un Estado ideal. En efecto, ante la corrupción de la vida ética griega, Platón hizo consciente una forma más alta de organización que irrumpía en dicha vida ética y la intentó plasmar en su Idea de República; Idea con la que, pensaba, se podía dar solución a aquella corrupción que aquejaba a su Estado. Pero con ello, según Hegel, Platón "hería profundamente su impulso más hondo, la libre personalidad infinita": <<Platón expone en su República la eticidad sustancial en su belleza y verdad ideales, pero no pudo dar cuenta del principio de la particularidad independiente que había irrumpido en su época en la eticidad griega [...] Esta carencia es lo que hace desconocer la gran verdad sustancial de su República y que corrientemente se la considere como un ensueño del pensamiento abstracto, como lo que con frecuencia se suele llamar un ideal >>.106 A pesar de que Platón logró captar la verdadera eticidad del mundo griego y la intentó poner en ideas, no logró, sin embargo, elevar a Idea el principio de personalidad (libre particularidad) que emergió en su tiempo. De

\footnotetext{
${ }^{105}$ G. W. F. Hegel, Principios de la filosofía del derecho (Barcelona: Edhasa, 1999), p. 58.

${ }^{106}$ Ibíd., p. 306.
} 
ahí que, a partir de esta carencia, su República aparezca como una forma todavía externa a la verdadera ética griega, y no como una forma interna al espíritu más alto de la misma.

Así, desde el punto de vista de Hegel, la Idea platónica de República es a la vez abstracta y concreta. 107 Concreta porque manifiesta la verdad que se agita ya en la vida ética griega; abstracta porque todavía no se ha realizado del todo en el Estado griego, y porque además no contiene aún el principio de particularidad que ha irrumpido en el mismo. En términos aristotélicos, la Idea platónica se halla aún en potencia, mas no así en acto. De esta manera, <<el resultado a que se llega, en Platón y Aristóteles, es como hemos visto la Idea; sin embargo, en Platón veíamos cómo lo general se hacía valer de un modo más bien abstracto como la idea inmóvil, mientras que en Aristóteles el pensamiento se torna totalmente concreto en la efectividad como el pensamiento que se piensa a sí mismo>>.108 Mientras Aristóteles exige la concreción de la Idea, en Platón parece quedarse en última instancia en lo abstracto ${ }^{109}$, y es aquí donde reside el gran límite de la Idea platónica.

No obstante, a pesar de su carácter abstracto, las Ideas platónicas no se reducen a meros principios regulativos tal como las interpreta Kant, sino que, como ya se dijo antes, mediante ellas Platón captó y concibió el espíritu verdadero de su propio tiempo, del mundo griego. Para Hegel, Platón ha mostrado con ello un espíritu sumamente elevado. Pero también ha mostrado, y esto merece especial énfasis, que el eje en torno al cual gira la parte medular de su Idea —en particular la Idea de una República perfecta- es el mismo eje en 257.

${ }^{107}$ Cfr., G. W. F. Hegel, Lecciones sobre la historia de la filosofía II (México: FCE, 1955), pp. 233 y

${ }^{108}$ Ibíd., p. 333. De acuerdo con Hegel, <<el momento fundamental de la filosofía aristotélica consiste, por tanto, en que la energía del pensamiento y lo pensado objetivo sean una y la misma cosa [...] No es lo pensado lo excelente, sino la energía misma del pensamiento; la actividad de la asimilación no hace sino crear lo que aparece como asimilado>>. Ibíd., p. 265.

${ }^{109}$ Es así que mientras Platón se limita a investigar cuál es la mejor forma de organización estatal y, por ello se enfoca en la búsqueda de un Estado ideal; Aristóteles, por su parte, se limita a señalar que en el Estado han de gobernar los mejores, y no se interesa en determinar una forma de la constitución estatal ideal a la manera de Platón. 
torno al cual giraba ya la "inminente revolución (Umwälzung) del mundo". Este eje es el principio ya mencionado: $<<$ Lo que es racional es real, y lo que es real es racional $>>110$; principio en el que, toda consciencia inmediata y toda filosofía, depositan su confianza al juzgar sobre el universo natural y espiritual. De esta manera, basado en estos dos "maestros del género humano" como lo son Platón y Aristóteles, Hegel busca dilucidar su noción de efectividad como la unidad indisoluble entre el ser y el pensar. La categoría de efectividad se trata pues de una unidad que refiere a la realidad como pensamiento y al pensamiento como realidad.

En otros términos, para Hegel no existe un mundo inteligible que se encuentre más allá de un mundo sensible que se le oponga. El mismo mundo sensible no es sino por la transformación que lleva a cabo el pensamiento sobre lo inmediato (toda cosa es transformada en el pensamiento, por lo que toda cosa no es sino un objeto para el pensamiento). Así, de acuerdo con Hegel, la relación entre el pensamiento y lo real no es una relación descriptiva, sino constitutiva. Cuando el pensamiento piensa una cosa la constituye como tal, y cuando logra reconstituirla reflexivamente en sus determinaciones esenciales, entonces se presenta como una cosa realmente efectiva.

En este sentido, la realidad efectiva es aquella realidad plenamente constituida, en todas sus determinaciones, por el movimiento reflexivo. De modo que, la efectividad no es algo ontológicamente dado, sino el último momento de la reflexión en su esfuerzo por pensar lo real, es la completa reconstitución de lo que aparece como algo inmediato. Es la reflexión la que, mediante la transformación plena de lo inmediato, hace de esa inmediatez un producto entero del pensamiento. $\mathrm{Y}$ es justo esta realidad plenamente constituida por la razón la que merece el nombre de realidad efectiva.

${ }^{110}$ G. W. F. Hegel, Principios de la filosofía del derecho (Barcelona: Edhasa, 1999), p. 59. 
Es de este modo que con la categoría de realidad efectiva, en tanto unidad de ser y pensar, Hegel se opone a la metafísica tradicional que concibe a la realidad y al pensamiento como algo separado. Cabe señalar que Hegel aborda la cuestión de la metafísica en su estudio sobre la lógica. Esto tiene una explicación. Nuestro autor piensa que existe una unidad indisoluble entre ambos dominios. De acuerdo con Hegel, corresponde a la filosofía kantiana el mérito de transformar la metafísica en lógica: <<Es verdad que la filosofía crítica convirtió ya a la metafísica en lógica pero [...] dio al mismo tiempo por miedo al Objeto [...] una significación esencialmente subjetiva a las determinaciones lógicas, en virtud de la cual éstas quedaron precisamente sujetas al Objeto del que huían, dejándose como resto, como un más allá, una cosa-en-sí, un choque inicial infinito>>.111 Según Hegel, Kant mantiene "una ternura hacia las cosas mundanas" que le hace dejarlas intactas y concentrarse sólo en la subjetividad, con lo cual sigue manteniendo una relativa separación entre lo sensible y lo inteligible.

A pesar de que Kant afirma que todo concepto sin intuición es vacío y que toda intuición sin concepto es ciega ${ }^{112}$ (que se puede traducir como la unidad entre entendimiento y sensibilidad), postula todavía una "cosa en sí" que, aunque perfectamente pensable, permanece indeterminada y, por tanto, resulta incognoscible. La cosa en sí es postulada como algo que, en tanto pensable, contiene alguna determinación; pero al mismo tiempo, en tanto escapa a toda determinación, es algo indeterminado. O mejor dicho, es algo que tiene la única determinación de estar indeterminado. ${ }^{113}$ No obstante, a pesar de

\footnotetext{
${ }^{111}$ G. W. F. Hegel, Ciencia de la lógica (Madrid: Abada, 2011), p. 200.

$112<<$ Pensamientos sin contenidos, son vacíos; intuiciones sin conceptos, son ciegas〉>. Immanuel Kant, Crítica de la razón pura (Buenos Aires: Losada, 2004), p. 226.

$113<<$ La cosa en sí [...] expresa el objeto en la medida en que se abstrae de todo lo que éste es para la conciencia, de todas las determinaciones de la sensación, así como de todos los pensamientos determinados referidos a él. Es fácil ver lo que queda entonces: lo perfectamente abstracto, lo completamente vacío solamente determinado como lo más-allá; lo negativo de la representación, de la sensación, del pensamiento determinado, etc. $\mathrm{Y}$ es igualmente simple la reflexión de que este caput mortuum es, él mismo el mero producto del pensar y precisamente del pensar llevado hasta la pura abstracción; un producto del yo vacío que convierte esta vacía identidad suya en objeto para él〉>. G. W. F. Hegel, Enciclopedia de las ciencias filosóficas (Madrid: Alianza, 1999), p. 145.
} 
que por temor o por ternura hacia los objetos, la filosofía kantiana mantenga el postulado de una cosa en sí, Hegel le reconoce el haber logrado ya una cierta identificación entre lógica y metafísica.

Es la "revolución copernicana" de Kant la que transforma la metafísica clásica en lógica trascendental, donde el sujeto ya no gira en torno al objeto, sino éste alrededor de aquél. No obstante, a pesar de esta gran transformación en el modo de pensar, la filosofía kantiana otorgó a las categorías lógicas un sentido más subjetivo que objetivo114; pues el objeto se le impuso al sujeto como algo totalmente independiente. En esta filosofía el objeto afecta las determinaciones lógicas que le rehúyen, por lo que el objeto permanece como un límite insuperable, esto es, como una "cosa en sí" que se encuentra más allá de las meras capacidades subjetivas.

Hegel criticará a Kant por mantenerse en un mero "idealismo subjetivo", pero no partirá sino del propio 'giro copernicano' que convierte a la metafísica en lógica. Hegel pronto retoma esta inversión y la revoluciona aún más, de este modo lleva a la revolución kantiana hasta sus últimas consecuencias. Hegel no sólo sostiene a la metafísica como lógica, sino que también transforma a la lógica en metafísica, algo que desde la filosofía crítica no se podría sostener sin traicionar el postulado de una "cosa en sí".

A diferencia de Kant, para Hegel no queda ninguna inmediatez, ninguna "cosa en sí" que no sea subsumida por el movimiento reflexivo del pensamiento. De ahí que no quepa hablar más de una independencia entre el ser y el pensar, o en términos kantianos de una independencia de lo sensible (intuición) con respecto a lo inteligible (concepto). La diferencia crucial en este punto entre la filosofía kantiana y filosofía hegeliana parece radicar en la concepción que una y otra tiene de las categorías. En la filosofía de Kant las categorías lógicas son

$114<<[\ldots]$ las categorías tienen su fuente en la unidad de la autoconsciencia y [...] por consiguiente, el conocimiento [que se alcanza] por su medio no contiene en efecto nada objetivo; la objetividad que se atribuye a las categorías es en sí misma algo meramente subjetivo. Si sólo se atiende a esto la crítica kantiana resulta meramente un idealismo subjetivo $[\ldots]>>$. Ibíd., p. 146. 
modos de predicar. Son conceptos puros que representan modos de pensar, esto es, modelos (formas puras) del pensamiento que modelan (o configuran) los datos sensibles para constituir la experiencia — por lo que desde esta filosofía conocemos sólo conceptos, y no las cosas en sí mismas-.

En cambio, en Hegel las categorías lógicas —o determinaciones de la reflexión como prefiere llamarles-, más que simples modos de pensar y predicar, son modos de ser realmente, pues el ser carente de pensamiento y predicación carece de realidad. Así, fuera de toda determinación inteligible y categorial, el ser carece tanto de pensamiento como de predicación alguna y, por tanto, de realidad misma: ser es ser pensado conceptualmente (por lo que de acuerdo con esta filosofía sólo conocemos a los cosas como conceptos, lo cuales constituyen a las cosas en sí mismas; por tanto, conocemos a las cosas en sí mismas en su concepto). ${ }^{115}$

Es justamente con la categoría de realidad efectiva que Hegel busca negar la pretendida independencia entre el pensamiento y la realidad. Con ella nuestro autor se enfrenta también a todas aquellas metafísicas que sostienen una racionalidad inmanente al mundo, independiente de la actividad del pensamiento, lo cual equivale a sostener la existencia de una razón no humana en un mundo puramente humano, por lo que para Hegel en términos lógicos esto carece de sentido. En la filosofía hegeliana no hay racionalidad en un mundo inmediatamente dado y externo al pensamiento. Esto muestra que Hegel no es el responsable de santificar el mundo puramente existente. Es la metafísica clásica la culpable consagrar lo que existe de hecho, pues sostiene que la tarea del pensar consiste en revelar la racionalidad que hay dentro de lo empíricamente dado, esto es, la racionalidad inmanente al ser existente.

${ }^{115}$ En este sentido, ya no es posible hablar de cosas fuera del pensar, ni de sujetos soportes de formas puras recluidas en su pensar. Las reglas del pensamiento son las reglas del objeto, y las reglas del objeto son las reglas del pensamiento; o mejor dicho, las reglas son reglas (unidad de ser y pensar). 
Pero si, tal como afirma la noción hegeliana de realidad efectiva, el ser no es sino por el pensar, entonces el contenido del pensamiento no puede ser algo independiente de la forma del pensamiento mismo; y al no haber diferencia entre ellos, son una y la misma cosa. No se puede todavía hablar de formas sin contenido ni de contenidos sin forma: todo lo racional es real, y todo lo real es racional (lógica y metafísica coinciden). ${ }^{116}$ En este sentido, Hegel construye una verdadera metafísica, alcanza a pensar el ser en cuanto ser, esto es, en cuanto logos (ser-pensar).

No obstante, al declarar la realidad de lo racional y la racionalidad de lo real en su filosofía del derecho, Hegel ha sido objeto de escándalo, pues dicha declaración es interpretada como una recaída en la metafísica dogmática, lo cual es considerado como algo imperdonable, máxime cuando se adscribe al dominio de la política. Así, con este dictum basado en la realidad efectivamente racional, la filosofía hegeliana ha sido acusada, incluso todavía más que sus predecesores racionalistas, de propugnar la santificación del orden existente de las cosas. De modo que la noción de realidad efectiva en Hegel parece derivar en faltas metafísicas aún más graves que las generadas por aquellos racionalistas que ven en lo puramente real la presencia de la razón.

Esto nos muestra que debemos evitar cualquier interpretación precipitada de la realidad efectiva. Como hemos visto, Hegel nos advierte que la realidad efectiva no es cualquier realidad. Algo merece el nombre de realidad efectiva sólo en la medida en que ha sido determinado completamente por el pensamiento. Sólo aquello que es plenamente reconstituido en un todo

$116<<[\ldots]$ la lógica y metafísica coinciden, la ciencia de las cosas plasmadas en pensamientos los cuales fueron tenidos por válidos para expresar las determinaciones esenciales de las cosas [...] Al intentar el pensamiento hacerse con un concepto de las cosas, éste [...] no puede consistir en determinaciones y relaciones que sean extrañas y exteriores a la cosa [...] Que en el mundo hay entendimiento o que en el mundo hay razón dicen lo mismo que la expresión "pensamiento objetivo". Esta última [expresión] es, sin embargo, incómoda porque demasiado comúnmente se considera que el pensamiento sólo pertenece al espíritu o a la conciencia y lo objetivo solamente se usa a su vez en primer lugar para lo no espiritual〉>. Ibíd., p. 131. 
coherentemente, en una trama entera de determinaciones, puede ser considerado realmente efectivo.

A pesar de que la categoría de realidad efectiva aparece en diferentes partes de la filosofía hegeliana, su desarrollo sistemático no se presenta sino en la Ciencia de la lógica. Ciertamente la Lógica hegeliana pretende pensar lo que es, pero es justo en su esfuerzo por pensarle que produce reflexivamente las determinaciones esenciales del ser pensado. Así, en la Lógica, antes de pensar la realidad como realidad efectiva, el pensamiento atraviesa por una serie de momentos que no son sino diferentes grados de determinación del ser pensado. En un primer momento el ser pensado se presenta como mera apariencia, para luego mostrarse en su aparición, la cual no es sino su propia exteriorización:

Su aparición no es — dice Hegel— sólo la reflexión dentro de otro, sino dentro de sí; y su exterioridad, por consiguiente, la externalización de aquello que él, en sí, es; y como, de este modo, su contenido y su forma son sencillamente idénticos, él no es entonces en y para sí otra cosa que este hecho de externalizarse. Él es el acto de revelar su esencia, de modo que esta esencia no consiste sino en ser lo que se revela. La relación esencial, en esta identidad de la aparición con lo interno o la esencia, se ha determinado hasta ser la realidad efectiva. ${ }^{117}$

En su aparición, el ser pensado es, ciertamente, una exterioridad, pero tal exterioridad no es sino una externalización de sí mismo, de su esencia. ${ }^{118}$ La exteriorización del ser consiste en revelar su esencia, y la esencia no es sino el ser que se revela, esto es, el ser que se exterioriza a sí mismo en la existencia. Y esta unidad entre la esencia y la existencia es la realidad efectiva, ya que ésta se refiere precisamente a la unidad entre la esencia (interna) y la apariencia (externa) del ser pensado. ${ }^{119}$ Se puede decir entonces que, la esencia del ser es

\footnotetext{
${ }^{117}$ G. W. F. Hegel, Ciencia de la lógica (Madrid: Abada, 2011), pp. 589-590.

118 <<Lo que algo es, lo es por consiguiente íntegramente dentro de su exterioridad; su exterioridad es su totalidad, ella es precisamente en la misma medida su unidad reflexionada dentro de sí >>. Ibíd., p. 589.

${ }^{119}$ En otros términos, la realidad efectiva es la unidad de esencia y apariencia, en tanto la realidad efectiva constituye en la Lógica la tercera sección que subsume a las dos anteriores, que son justo la esencia y
} 
su propia existencia. En la realidad efectiva la reflexión logra una unidad entre lo interno y lo externo, entre forma y contenido, pues la "reflexión dentro de sí" y la "reflexión dentro de otro" terminan siendo algo idéntico, cada una encuentra su identidad en su diferencia. ${ }^{120}$

La realidad efectividad es, entonces, aquella exterioridad que es completamente interna y aquella interioridad que es plenamente externa, por lo que <<su inmediatez está puesta como la reflexión-dentro-de-sí, y viceversa >>.121 La realidad efectiva es la realidad completamente tomada o aprehendida por el movimiento reflexivo del pensamiento, es la realidad plenamente determinada por las formas que la reflexión produce en su esfuerzo por pensarle, y no tiene más determinaciones que las producidas por la reflexión. Así, la exterioridad de la realidad no es sino la manifestación de su esencia producida por el movimiento reflexivo que intenta pensarla. Es en su esfuerzo por pensar la realidad que la reflexión elabora sus determinación para lograr pensar su esencia (en este sentido, no hay por un lado el ser y por otro lado su esencia, aunque ésta tampoco es algo que se encuentre al interior del ser, sino que ella surge en el momento en el que se lo trata de pensar esencialmente).

Así, <<la realidad efectiva es —advierte Hegel— la unidad de la esencia y la existencia; dentro de ella tiene su verdad la esencia carente de figura y la aparición inconsistente: o sea, el consistir, que carece de determinación, y la multiforme variedad, que carece de consistencia $>>.122$ De este modo, la realidad efectiva es la unión de la unidad reflexiva y la multiplicidad sensible, pero se

la apariencia. En un primer momento, la realidad del ser aparece como presupuesta, pero al reflexionar sobre el ser, el pensamiento muestra su esencia, que no es sino su propia realidad. La realidad se manifiesta a sí misma, es realidad efectiva. En este último sentido, la realidad no es algo presupuesto, sino algo puesto, puesto como lo que efectivamente es: el resultado del proceso del pensamiento. No hay nada más, nada oculto, que le dé efectividad a la realidad fuera de la actividad del pensamiento.

${ }_{120}$ Aunque en los momentos precedentes lo interno y lo externo se encuentran ya en mutua determinación, no será sino hasta la realidad efectiva donde encuentren su plena unidad, por lo que antes de esta unidad lo que es todavía no puede ser considerado como algo realmente efectivo.

${ }^{121}$ Ibíd., pp. 604-605.

${ }^{122}$ Ibíd., p. 591. 
trata de una unión que sólo se alcanza a través de un proceso de mutua transformación entre los dos polos de la relación, esto es, por las etapas que atraviesa la determinación recíproca entre el ser y el pensar. Proceso en el que la esencia carente de determinación va adquiriendo contenido; y la existencia carente de consistencia va adquiriendo forma. Las determinaciones del pensamiento otorgan consistencia a la multiplicidad empírica y las determinaciones de lo real otorgan contenido a las formas de la reflexión.

No obstante, Hegel no nos presenta a un pensamiento portador de formas racionales confrontado con una realidad acabada con determinaciones dadas independientes del pensamiento, sino una unidad que se autodiferencia; y en este autodiferenciarse se van constituyendo sus dos polos que, al confrontarse, se van identificando y diferenciando como tales. Aquí Hegel coincide con Kant en que todo objeto sólo es tal por su determinación en la unidad del pensamiento, pero difiere de él en cuanto considera que no hay una realidad en sí que sea pensada y que, al mismo tiempo, escape a las determinaciones del pensamiento, y frente a la que éste tenga sólo una función representativa.

Hegel no acepta, como Kant, que exista por un lado la realidad y por otro el pensamiento con una cierta estructura cognoscitiva. Para nuestro autor, en la doctrina kantiana las formas a priori de la sensibilidad reciben su materia del exterior y las formas a priori del entendimiento la subsumen a la forma objetiva interna. Pero en tanto el entendimiento cuenta sólo con una cierta estructura categorial, no puede lograr una síntesis plena del objeto dado, por lo que éste permanece como una cosa irreductiblemente exterior, como una cosa en sí a la que no se tiene acceso cognoscitivo. Existe una separación entre ser y pensar, en la que este último no puede conocer al primero, esto es, a las cosas 
en sí mismas. De este modo existe un vacío entre las formas universales del entendimiento y el contenido particular de la sensibilidad. ${ }^{123}$

No obstante, con la noción de realidad efectiva, Hegel va más allá de Kant, ya que con ella critica la existencia de cualquier forma a priori del conocimiento y de cualquier sustrato ajeno al mismo. En la realidad efectiva, tanto el objeto pensado como el pensamiento que lo piensa se van constituyendo de modo simultáneo en el mismo proceso del conocimiento. El pensamiento no cuenta con una determinada estructura conceptual con la que deba representarse al objeto dado, sino que es en su esfuerzo por pensarle que genera las determinaciones esenciales del mismo; determinaciones que en tanto definen la esencia del objeto pensado, como constituyen como tal. Es en el proceso de conocimiento que el pensamiento produce al objeto en su verdad a la vez que produce las determinaciones con las que lo piensa, donde el pensamiento se produce entonces a sí mismo. De esta manera, el pensamiento puede determinar completamente al objeto $\mathrm{y}$, por ende, puede alcanzar un verdadero conocimiento del mismo sin que se le escape un resto en sí. No hay un ser puramente externo, ni un pensamiento puramente interno; todo interior es exterior y todo exterior es interior. Hay una unidad entre ser y pensar, y esto es la realidad efectiva. Pero lo realmente efectivo no se encuentra de inmediato, sino que se requiere de un trabajo reflexivo para reconstituir al objeto pensado en su verdad, en la unidad de lo interno y lo externo.

El pensamiento únicamente admite como realidad efectiva sólo aquello que ha constituido como resultado. Lo efectivo no es lo meramente observable, sino lo reflexivamente constituido, por lo que, en tanto producto de la razón, no puede dejar de ser racional. Lo racional de lo efectivo, aquella escandalosa proposición del "Prefacio" a los Principios de la filosofía del derecho, encuentra aquí, en esta consideración de la realidad efectiva, su razón de ser. Siendo este

${ }^{123}$ Este vacío, como hemos apuntado, en tanto sólo se puede cerrar imperfectamente con el discernimiento (o Juicio), lleva a la postulación de un principio regulativo que busque una unidad más alta conforme a las exigencias últimas de la razón. 
el sentido completo de efectividad, cabe preguntarnos si todavía cabe escandalizarse ante las más altas pretensiones de unidad de la razón y considerarla como totalitaria (en este sentido, es de sorprender que se pretenda ignorar el intento de Hegel por establecer una razón teórico-práctica, pero lo es aún más el pretender omitir su esfuerzo por erigir un tribunal de la razón en la historia que juzgue al propio tribunal de la razón trascendental).

Pero, si bien la realidad efectiva ha sido aquí ya definida como la unidad entre el ser y el pensar, todavía falta que dicha unidad sea aprehendida por el pensamiento mismo como su verdad. En la Lógica, el pensamiento partió del ser como algo inmediatamente dado para ponerlo como ser pensado, posteriormente el pensamiento lo medió reflexivamente haciéndole mostrar su esencia. De modo que en la realidad efectiva ser y esencia se piensan ya como unidad, y sólo le restará al pensamiento mostrar esta unidad como lo verdaderamente concreto, esto es, como concepto. Pero antes de pasar al concepto, Hegel dedicará una sección dividida en tres apartados a mostrar que la realidad efectiva, en tanto no es más que el producto de la reflexión, puede ser determinada de diferentes modos antes de alcanzar su completa verdad como algo absolutamente necesario.

Con el fin de desarrollar su noción de realidad efectiva, Hegel recurre entonces a la exposición de las categorías modales que Kant había tratado ya en la Crítica de la razón pura ${ }^{124}$, tales modalidades son: posibilidad, contingencia y necesidad.125 Kant fue el encargado de transformar radicalmente la comprensión de estas categorías modales al trasladarlas de lo externo (ya sea de un supuesto orden trascendente o inmanente al mundo) a lo

\footnotetext{
${ }^{124}$ Véase Immanuel Kant, Crítica de la razón pura (Buenos Aires: Losada, 2004), pp. 358 y ss.

${ }^{125}$ El examen de las modalidades aparece al final del recorrido que la reflexión emprende a través de las figuras de la Doctrina de la esencia. Hegel expone estas categorías modales específicamente en la Sección tercera ("La realidad efectiva") del Libro segundo ("Realidad efectiva") de la "Doctrina de la esencia". De modo que esta Sección tercera constituye el tránsito a la "Doctrina del concepto", en la cual se muestra la unidad de las doctrinas anteriores, a saber, la "Doctrina del ser" y la "Doctrina de la esencia". En este sentido el Concepto vendría a constituir la plena unidad de ser y esencia; unidad que ya se ve anunciada en la realidad efectiva.
} 
interno (al pensamiento), es decir, al sujeto de conocimiento. De modo que estas categorías no expresan sino la forma en la que el pensamiento da unidad a la existencia, esto es, el grado de unificación que alcanza el pensamiento en el mundo existente a través de las mismas.

Pero aunque Kant tiene el mérito de traer las categorías modales al ámbito del sujeto, mantiene dichas categorías como algo perteneciente sólo a la estructura subjetiva del mismo. De modo que si bien el sujeto puede representarse con ellas la estructura del mundo, en tanto puramente subjetivas, dejan a este último intacto como algo que sólo es objeto de predicación. Observemos detenidamente. Kant pretende fundamentar el conocimiento humano a partir del hallazgo de las condiciones de posibilidad de la objetividad. Objetividad que de acuerdo con él, vendrá dada por la unificación de la multiplicidad sensible en una unidad inteligible, esto es, en un concepto puro del entendimiento o categoría.

Las categorías del entendimiento constituyen entonces las condiciones de posibilidad de todo objeto de experiencia, pues sin ellas, las intuiciones sensibles no encontrarían mayor consistencia que la otorga por las intuiciones puras (espacio y tiempo). La objetividad del objeto únicamente puede ser pensada bajo las categorías. ${ }^{126}$ No obstante, a pesar de que las categorías en general representan las condiciones de posibilidad del objeto de experiencia, dentro de la división que Kant hace dichas categorías se encuentran unas que no cumplen con esta función: las categorías modales. ${ }^{127}$

\footnotetext{
${ }^{126}$ Pero aunque las categorías son las encargadas de otorgar objetividad a la experiencia, se trata sólo de una objetividad relativa, pues únicamente permiten representarse a la cosa como fenómeno, mas no como nóumeno; esto debido a que, en tanto conceptos puros, las categorías permanecen externas a las cosas en sí mismas.

127 Dentro de la filosofía kantiana, las categorías se dividen en cuatro grupos: cantidad (unidad, pluralidad, totalidad); cualidad (realidad, negación, limitación); relación (inherencia y subsistencia [substantia et accidents], causalidad y dependencia [causa y efecto], comunidad [reciprocidad entre agente y paciente]; y modalidad (posibilidad/imposibilidad, existencia/ no-existencia, necesidad/contingencia). Cfr. Ibíd., p. 247.
} 
Efectivamente, dentro de la tabla de categorías que Kant deduce, el único grupo que no se refiere a las condiciones de existencia del objeto es el de la modalidad. De acuerdo con nuestro filósofo de Königsberg, $<<$ las categorías de modalidad tienen de particular que no aumentan en nada, como determinación del objeto, el concepto a que se unen como predicados, sino que sólo expresan la relación con la facultad de conocer>>. ${ }^{128}$ Y líneas más adelante Kant continúa: $<<$ Cuando el concepto de una cosa es ya completo, puedo aún preguntar si ésta es simplemente posible, o si es real, y en último caso, si además es también necesaria. No se piensa con esto ninguna determinación más en el objeto mismo; pues sólo se trata de saber cuál es la relación de este objeto y de todas sus determinaciones con el entendimiento y su uso empírico, con el juicio empírico y con la razón (en su aplicación a la experiencia)>>. ${ }^{129} \mathrm{Si}$ bien, todo objeto para poder ser juzgado (para convertirlo en objeto de juicio) ha de tener que ser pensado bajo alguna de las categorías modales, dichas categorías no agregan nada sobre el contenido del objeto, pues este ya se encuentra reconstituido por las demás categorías. De modo que las categorías de modalidad no se refieren más que a la relación que tal objeto guarda con el entendimiento. Una vez que el objeto es reconstituido por las categorías, entonces puede ser juzgado mediante las categorías de modalidad para determinarle como posible, real o necesario. Estas categorías no agregan ninguna determinación al objeto, sino sólo muestran bajo qué forma se presenta dicho objeto ante el pensamiento.

Hegel se basa en Kant para decir que es el pensamiento el responsable de producir las modalidades con las que se piensa al mundo existente, pero va más allá al sostener que dichas modalidades no sólo otorgan estructura al mundo sino que lo constituyen como tal, con esa estructura. Así, en la Lógica hegeliana las categorías modales más que caracterizar la postura que adopta el

\footnotetext{
${ }^{128}$ Ibíd., pp. 358-359.

${ }^{129}$ Ibíd., p. 359.
} 
pensamiento frente a lo existente, son una forma específica de constituir la existencia misma.

De acuerdo con nuestro autor, la verdad de la cosa pensada no se halla sino en las categorías (o mejor dicho en las determinaciones) con las que se piensa dicha cosa, aún más, son los conceptos mismos lo que constituyen a la cosa como tal. La verdad de las cosas se encuentra en su concepto, su verdad sólo viene dada por el pensamiento conceptual. Si la existencia se presenta como tal, es sólo por la actividad reflexiva del pensamiento, por lo que no puede haber afirmación sobre lo existente fuera dicha actividad. Así, en tanto las categorías modales — posibilidad, contingencia y necesidad — expresan la forma en la que el pensamiento constituye la existencia misma, ésta puede ser declarada posible o imposible, contingente o necesaria, relativamente necesaria o absolutamente necesaria. ${ }^{130}$

Al tratar de pensar la realidad efectiva como algo absolutamente necesario, el pensamiento atraviesa por una serie de momentos que se van mostrando insuficientes ante las propias exigencias lógicas del pensamiento. Pero estos momentos, que no son más que las modalidades, son modos de ser, y no de predicar. Las categorías modales no se refieren a una especie de vínculo entre lo real y el pensamiento como si tuvieran una existencia por separado. No se trata de presuponer una realidad a la que el pensamiento le aplicará las categorías modales, pues al hacerlo éstas le quedarían extrínsecas a tal realidad y sólo representarían modos de juzgarla. Las categorías modales se refieren a la realidad efectiva (a la realidad completamente pensada o a la realidad como pensamiento) en su propia determinación, por lo que son modos de ser realmente de la efectividad; no son categorías ajenas a lo efectivo, sino modos en los que se constituye como realidad efectiva. Las modalidades no son modos de pensar lo real, sino modos de constituir la realidad misma. En el

130 De modo general, la posibilidad se presenta como opuesta a la imposibilidad, la contingencia como opuesta a la posibilidad y la necesidad como opuesta a la contingencia. 
momento en el que la realidad efectiva es pensada como posible, contingente o necesaria, se le constituye como tal. Estas categorías modales no son, entonces, pensadas al margen de la efectividad, sino que surgen justo en el esfuerzo por pensar la realidad efectiva. Así, la noción de efectividad subyace a todo el tratamiento de las categorías modales.

Es de este modo que Hegel hace de la realidad efectiva el eje rector de toda la reflexión sobre las categorías modales, ya que tal reflexión no puede partir sino de la presencia efectiva de la cosa que es pensada, y no de la mera abstracción del pensamiento. Así, la exposición de las modalidades parte de la realidad efectiva, pero en el proceso de su determinación que va de lo más abstracto a lo más concreto, irá adoptando distintos significados, los cuales sólo tomarán su pleno sentido en la determinación última como realidad efectiva absolutamente necesaria.

Hegel intentará mostrar, pues, que las categorías modales no son sino diferentes momentos de determinación tautológica de la propia realidad efectiva. Constituyen momentos autorreferenciales de la propia efectividad. Es la propia realidad efectiva la que se muestra como posible, como contingente o como necesaria; y no son la posibilidad, la contingencia y la necesidad las que se vuelven realidad. Es al pensar la realidad que ésta se puede mostrar bajo alguna de estas modalidades, y es justo cuando se paraliza el proceso reflexivo que lo real aparece como posible o contingente, pero cuando se lleva a su límite se muestra entonces como necesario. ${ }^{131}$

Hegel considera que si la realidad efectiva es completamente pensada, entonces se manifiesta como algo absolutamente necesario. Nuestro autor recurre entonces a la exposición de las categorías modales tradicionales para probar que cada una de ellas no es sino la abstracción de lo realmente efectivo

131 El movimiento de transición de una categoría modal a otra resulta esencial para comprender la relación que la reflexión mantiene con respecto a la realidad efectiva, la cual es determinada según la modalidad que alcance a pensar el propio movimiento reflexivo. Y es en la transición de las categorías modales donde la realidad efectiva es constituida en última instancia como necesaria. 
que es necesario en sentido absoluto. Hegel pretende reconstruir la necesidad absoluta de la realidad efectiva con base en un proceso racional. Frente a las filosofías que pretenden considerar a este mundo como siendo sólo uno posible entre otros, Hegel se remite a los hechos duros del mundo realmente efectivo, el único que existe, el único verdadero, para pensarlo en su necesidad absoluta. 


\section{La categoría de realidad efectiva: posibilidad, contingencia y necesidad}

En la Ciencia de la lógica, Hegel busca desarrollar la categoría de realidad efectiva a través de las modalidades: posibilidad, contingencia y necesidad. Así, nuestro autor abordará estas categorías modales heredadas por la metafísica, pero las reconstruirá con base en el lugar que ocupan dentro del movimiento de la reflexión. Al referirse a las categorías modales, Hegel parece estar siempre refiriéndose a posiciones específicas dentro de la historia de la filosofía. Así, aunque las toma prestadas de la tradición filosófica, nuestro autor pretende reconstruirlas con el fin de mostrar qué hay en realidad detrás de su desarrollo. De acuerdo con Hegel, en la determinación histórica de las categorías modales subyace siempre el movimiento de la reflexión, en el cual lo que está en juego es la relación del pensamiento con la realidad. De ahí que en la reflexión misma sobre las modalidades se observa un movimiento en el que existe un vaivén entre el ser y el pensar, y en el que se va dando una cierta unidad entre ambos, entre la unidad del pensamiento y la unidad pensada. En el examen de las modalidades se encuentra latente, entonces, el pensamiento puesto como existencia y la existencia puesta como pensamiento.

En la reflexión sobre las modalidades (de posibilidad, contingencia y necesidad) encontramos, de este modo, tres momentos característicos de esta relación entre el ser y el pensar: un momento "formal", uno "real" y uno "absoluto". El momento formal se encuentra caracterizado por la ilusión del pensamiento que confunde las formas de la reflexión con las determinaciones del ser. El momento real se enfoca a la confrontación entre las determinaciones de la reflexión y la multiplicidad irreductible del ser. Y el momento absoluto es el de la mutua determinación entre la reflexión y el ser, cuya subsunción constituye la unidad completa de determinaciones. Así, siguiendo su proceder de demostración, que va de lo abstracto a lo concreto, Hegel comienza con la concepción formal de las modalidades ("Contingencia; o formal realidad 
efectiva, posibilidad y necesidad formales"); luego pasa al momento real ("Necesidad relativa, o real realidad efectiva, posibilidad y necesidad reales"); y finalmente, Hegel expone su propia visión especulativa de las modalidades en la "Necesidad absoluta".

\section{Momento formal}

En primer término, las modalidades en las que se presenta la realidad efectiva pertenecen al momento formal del pensamiento. Este momento formal de las categorías modales es el siguiente: "Contingencia; o formal realidad efectiva, posibilidad y necesidad formales". Nótese que es la noción de "contingencia" la que encabeza este apartado, y no así la noción de realidad, esto se debe a que es justo el momento formal el que muestra la contingencia tanto de la reflexión como de la cosa reflexionada. El ser y el pensar se muestran como algo separado que puede ser, o no ser, independientemente del otro. Así, este formalismo constituye sólo un momento abstracto de la realidad efectiva, pues recordemos que ésta no es sino la unidad entre el ser y el pensar, donde el uno no puede ser sin el otro y, por tanto, se requieren necesariamente. De acuerdo con Hegel, el formalismo constituye una forma de pensar que únicamente es capaz de lograr una cierta unidad entre el pensamiento y la cosa pensada en la medida en que los considera como algo dado de antemano, el uno frente al otro.

Si bien la efectividad es la unidad, efectuada por el proceso reflexivo, entre el pensamiento y la cosa, en el momento formal ambos son todavía considerados como algo puramente inmediato e independiente. Una cosa es formalmente efectiva en tanto se ofrece al pensamiento como algo inmediatamente dado: $<<$ La realidad efectiva es formal en la medida en que, al ser realidad-efectiva primera, es sólo inmediata, no reflexionada, con lo que no 
hace sino estar en esta determinación-de-forma, pero no como totalidad de la forma. Así, ella no es nada más que un ser o existencia en general >>.132

Lo formalmente efectivo es aquello que aún no ha sido plenamente reflexionado como realidad efectiva, por lo que se presenta como un simple "ser" o como una "existencia en general". La realidad efectiva es aquella realidad que es completamente pensada, aquella que es completamente determinada por el pensar (la realidad como pensamiento), pero en su momento formal, la reflexión todavía no distingue la realidad efectiva de la mera realidad, lo realmente efectivo del mero ser existente. De ahí que en este momento, lo formalmente efectivo no constituye todavía la unidad del pensamiento con la realidad, o de lo interno con lo externo. La realidad es determinada sólo formalmente por el pensamiento, las determinaciones de éste determinan a aquélla de modo externo. La forma del pensamiento simplemente se imprime sobre lo real.

Si bien, la realidad efectiva es la unidad de lo interno y lo externo, en este primer momento formal, dicha unidad es tomada inmediatamente como algo dado, y no como un producto entero de la reflexión. Pero aunque se trata de una unidad inmediata, ya es mediada de algún modo por la reflexión, ya que, aunque aún no es totalmente determinada por el pensamiento, constituye ya un momento de tal determinación. Así, en tanto unidad inmediata de interno y externo, la realidad formalmente efectiva es ya mediación; se trata de una inmediatez constituida por la mediación de la reflexión.

En un principio, la realidad efectiva se reflexiona como habiendo sido primeramente algo posible, por lo que se piensa como pura posibilidad: $<<$ como, esencialmente, no es ella [la realidad efectiva] mera existencia inmediata, sino que está como unidad-de-forma del ser en sí —o interioridad- y de la exterioridad, contiene entonces de inmediato al ser en sí, o la posibilidad >>. 133 En este momento formal, la única exigencia para que lo real sea realmente

\footnotetext{
${ }^{132}$ G. W. F. Hegel, Ciencia de la lógica (Madrid: Abada, 2011), pp. 605-606.

${ }^{133}$ Ibíd., p. 606.
} 
efectivo, es el haber sido posible. Lo único que se puede afirmar sobre la realidad efectiva es su posibilidad: <<Lo que es realmente efectivo es posible>>. ${ }^{134} \mathrm{Su}$ posibilidad es lo único que convierte a la realidad efectiva en causa de sí, y lo que hace que no dependa de otro externo (otra causa) para ser; su ser se lo debe a $s u$ posibilidad. Lo efectivo es precisamente por el hecho de haber sido ya posible. Es así como la Lógica nos reconduce de la realidad formalmente efectiva a su posibilidad formal.

De este modo, en tanto tiene necesariamente como punto de partida lo formalmente efectivo, la reflexión sobre las modalidades no comienza sino con la posibilidad, pues es en lo posible donde tiene su inicio la relación entre las determinaciones del pensamiento y las determinaciones de la cosa pensada. De ahí que en la Ciencia de la lógica la relación del pensamiento con lo pensado es, en un primer momento, reflexionada desde la modalidad de lo formalmente posible, esto es, desde lo lógicamente posible. En una primera instancia, la posibilidad formal se muestra más rica que la realidad, ya que lo formalmente posible rebasa los límites de lo real, lo cual viene a ser sólo una parte del amplio campo de lo posible.

Así pues, el pensamiento se enfrenta a lo formalmente efectivo primeramente a través de la categoría de posibilidad formal (o lógica), que se funda en el principio de no contradicción. En efecto, desde el punto de vista formal, la posibilidad lógica nos dice que lo posible es todo aquello que es pensable, y lo pensable es todo aquello que no es contradictorio consigo mismo. Entonces es posible todo aquello que no se contradice. De modo que, todo aquello que no se contradice es pensable y, a su vez, todo aquello que es pensable es formalmente posible.

Al definir lo posible como aquello que es pensable, el pensamiento alcanza ya una cierta unidad de sí, pues eso que es definido como posible no es

\footnotetext{
${ }^{134}$ Loc. cit.
} 
sino idéntico a sí mismo, le basta una coherencia interna para su posibilidad. En tanto la condición lógica de no contradicción basta para determinar la posibilidad formal, se puede observar que dicha posibilidad se funda en el principio de identidad. Pero mediante este principio, en su pura formalidad no resulta complicado saber que, estrictamente, toda cosa es distinta de toda otra y, en consecuencia, cualquier cosa puede ser declarada como idéntica a sí misma.

Ante esta indeterminación, el pensamiento formal cae en una noción abstracta del principio de identidad. Bajo esta identidad abstracta, el ámbito de la posibilidad no es sino el de la multiplicidad ilimitada y, por tanto, cualquier cosa es posible. En efecto, de acuerdo con Hegel, usualmente se dice que la posibilidad consiste en la capacidad de pensar; pero en tanto lo pensable es definido simplemente como lo no contradictorio, se basa entonces en las meras leyes del pensamiento abstracto, que tiende a caer en el vacío. Así, 'pensar' se entiende aquí como la aprehensión de un contenido en la forma de una identidad abstracta, y ya que cualquier contenido puede ser traído dentro de esta forma - siempre y cuando sea separado de las relaciones en las que realmente se sostiene-, entonces aun la más absurda e inesencial suposición puede ser considerada como posible. Esta identidad puramente formal puede entonces traer consecuencias absurdas para el pensamiento. Hegel se refiere irónicamente a tales consecuencias:

Es posible que la luna caiga sobre la tierra esta noche, ya que la luna es un cuerpo independiente de la tierra $\mathrm{y}$, por tanto, puede caer tan fácilmente como una piedra que ha sido lanzada al aire; es posible que el Sultán turco pueda llegar a ser Papa, ya que es un ser humano y, como tal, puede llegar a convertirse al cristianismo, y luego en sacerdote, etcétera. ${ }^{135}$

$135<<$ It is possible that the moon will fall on the earth this evening, for the moon is a body separate from the earth and therefore can fall downward just as easily as a stone that has been flung into the air; it is possible 
De la misma manera que con el principio formal de identidad, bajo el principio de no contradicción se puede afirmar que todo es posible, $<<$ sólo que con eso nada se ha dicho, al igual que con la proposición idéntica formal>>.136 De acuerdo con nuestro autor, en esta serie de posibilidades se halla presente el principio de razón suficiente [Denkgesetz vom Grunde], ya que de acuerdo con este principio, resulta posible toda aquella cosa cuya razón de ser pueda ser especificada a través de sus condiciones determinantes. Pero, según Hegel, mientras más inculta sea una persona, menos ella sabrá sobre las relaciones determinantes en las que se hallan aquellas cosas que pone en consideración, y con ello dicha persona se mostrará mayormente inclinada a considerar toda forma de vanas posibilidades (en política, por ejemplo, nosotros vemos esto dice Hegel - con los así llamados comentaristas políticos [Kannengießern]). De cualquier modo, de acuerdo con Hegel, en la vida ordinaria no faltan proverbios que expresen apropiadamente el sentido de esta posibilidad abstracta; verbigracia, se dice que $<<$ más vale pájaro en mano que ciento volando [A bird in the hand is worth two in the Bush]>>.137

De esta manera, ignorando el principio de razón suficiente, y ateniéndose sólo al mero principio de identidad, la conciencia ordinaria puede pensar todo tipo de posibilidades, pero aún desde el propio punto de vista formal, el mero principio de identidad resulta insuficiente para pensar lo efectivo, ya que, en su puro formalismo, dicho principio conduce a una noción abstracta de lo efectivo, donde dicha efectividad queda completamente indeterminada como algo meramente posible. No obstante, la reflexión sobre la posibilidad va más allá del mero principio de identidad, pues la definición de lo posible no es una mera transcripción de dicho principio.

\footnotetext{
that the Sultan may become Pope, for he is a human being, and as such he can become a convert to Christianity, and then a priest, and so on>>. G. W. F. Hegel, The Encyclopaedia Logic (IndianapolisCambridge: Hackett Publishing Company, 1991), p. 216.

${ }^{136}$ G. W. F. Hegel, Ciencia de la lógica (Madrid: Abada, 2011), p. 607.

${ }^{137}$ G. W. F. Hegel, The Encyclopaedia Logic (Indianapolis-Cambridge: Hackett Publishing Company, 1991), p. 217.
} 
De esta manera, lo formalmente posible cuenta en sí mismo con la innegable virtud de mostrar su propia insuficiencia: $<<$ Lo posible contiene, sin embargo, más que la proposición meramente idéntica. Lo posible es el serreflexionado-dentro-de-sí, reflexionado a su vez; o sea, lo idéntico sin más, como momento de la totalidad y, por ende, determinado también a no ser en sí>>.138 En este momento formal, el pensamiento tiene el mérito de poder diferenciar entre el principio de identidad exigido por la posibilidad y la determinación de la cosa pensada como algo realmente efectivo. Lo meramente posible es sólo algo posible, esto es, únicamente pensable; pero el que sea pensable, no lo hace necesariamente efectivo.

En efecto, todo lo que es efectivo es posible ${ }^{139}$, ya que es idéntico a sí mismo, esto es, su propia posibilidad fue condición necesaria para su efectividad misma. No obstante, a pesar de que lo efectivo es formalmente posible, no todo lo formalmente posible es efectivo. Mediante el principio de no contradicción, el pensamiento formal pretende proporcionar una forma de determinación para que la cosa no se contradiga y que la muestre como idéntica a sí misma, pero se trata de la exigencia de identidad de un pensamiento aún carente de cualquier determinación concreta. De modo que definir lo posible simplemente como lo no contradictorio, significa dejar la identidad de la cosa como algo indeterminado, ya que tal definición no da indicio alguno de la realidad efectiva de dicha cosa; no se sabe si lo posible es en efecto realmente posible.

De ahí que la posibilidad formal resulta insuficiente para determinar realmente lo efectivo. A pesar de que lo posible había sido definido como lo idéntico a sí mismo, al mismo tiempo se declara al propio principio de identidad como insuficiente para alcanzar una definición más concreta de lo efectivo, pues se queda en una mera identidad vacía (sólo igual a sí misma). En otras

\footnotetext{
${ }^{138}$ G. W. F. Hegel, Ciencia de la lógica (Madrid: Abada, 2011), p. 607.

${ }^{139}$ Cfr. Ibíd., p. 606.
} 
palabras, la identidad formal resulta insuficiente para determinar lo efectivo, en tanto todo aquello que es efectivo, no es sino por su otro, requiere de su no ser para ser. Lo realmente efectivo únicamente es por su otro, su otro (su no ser) constituye parte sustancial de su identidad. De modo que lo puramente idéntico se encuentra determinado "a no ser en sí".

Si algo es efectivo, entonces implica a su diferente. En tanto todo aquello que es efectivo implica a su otro (a su no ser), nada es sólo formalmente posible. Cuando se piensa algo como meramente posible, nada impide pensar incluso lo opuesto de ese algo también como posible. Si algo es solamente posible, entonces implica que lo otro es también solamente posible. Lo posible tiene la $<$ determinación de no ser más que un ser posible, el deber ser de la totalidad de la forma. Sin este deber ser, la posibilidad es la esencialidad en cuanto tal; pero la forma absoluta contiene el hecho de que la esencia misma es sólo momento, y de que sin el ser no tiene verdad>>.140 Lo sólo formalmente posible carece de realidad; es solamente un posible, que sin realidad carece de verdad.

Lo verdadero se halla sólo en lo realmente efectivo, lo cual implica su posibilidad formal. Ciertamente, toda realidad efectiva es formalmente posible, pero al ser efectiva incluye a su otro (su no ser), pues es lo que le otorga su identidad; por lo que todo lo realmente efectivo es contradictorio. La realidad efectiva incluye, pues, la contradicción (su otro, su no ser). En tanto el pensamiento formal se muestra incapaz de enfrentar la contradicción, trata de evadirla postulándola como un principio restrictivo (de ahí que declare que es posible aquello que no se contradice). Pero aunque el pensamiento formal trate de evitarle, la propia reflexión sobre la posibilidad introduce la contradicción.

Así, lejos de excluir el principio de no contradicción, la posibilidad formal es definida como la contradicción misma: $<<$ [la posibilidad] es el ser en sí, determinado como sólo un ser puesto; o bien, precisamente en el mismo sentido,

\footnotetext{
${ }^{140}$ Ibíd., p. 607.
} 
determinado como no siendo en sí. La posibilidad es, por consiguiente, en ella misma también la contradicción, o sea: es la imposibilidad $>>{ }^{141}$ Desde este ámbito formal, en el momento en el que se piensa algo como meramente posible, bien se puede pensar su opuesto como igualmente posible.

De este modo, cualquier cosa es posible, pero en tanto también su contrario es posible, entonces se cae en una completa indeterminación, por lo que todo es a la vez imposible. ${ }^{142}$ Lo formalmente posible introduce, entonces, la negatividad, pues en su identidad contiene a su otro, la imposibilidad. La posibilidad formal encierra, así, una contradicción: lo posible se presenta también como imposible. Lo meramente posible es lo posible indeterminado, o sea, lo imposible. Frente a lo efectivo, la posibilidad formal, que se había definido como lo no contradictorio, introduce ahora justo la contradicción. Con ello lo formalmente posible socava el principio sobre el que se había sostenido, termina en aquello que trataba de evitar: la contradicción. Mientras que en la concepción clásica de las modalidades lo posible era definido distinguiéndolo de lo real en virtud de su no contradicción, observamos que en la Lógica hegeliana la posibilidad es "en ella misma también la contradicción".

Y esta contradicción no desaparece a pesar de que lo posible sea redefinido como aquello cuyo opuesto no es necesariamente falso, pues tal definición, en tanto se funda de igual modo en el principio de no contradicción, pronto hace aparecer la misma. El que algo no sea falso con relación a su opuesto (es decir, contradictorio a su opuesto), da cabida a la posibilidad de ambos (al definir algo como meramente posible, se está definiendo a su otro de igual manera como meramente posible). Verbigracia, el que $A$ no sea

\footnotetext{
${ }^{141}$ Loc. cit.

${ }^{142}$ De acuerdo con Hegel, así como podemos decir que toda cosa puede ser considerada como posible, de igual manera podemos también decir que cualquier cosa puede ser considerada como imposible, ya que cualquier contenido concreto, como tal, contiene siempre no sólo diversidad sino también determinaciones opuestas. Así, por ejemplo, nada es más imposible que el hecho de que yo existo, ya que el "yo" es a la vez simple relación a sí como también, incondicionalmente, relación a otro. Y la misma situación se mantiene para todo otro contenido en el mundo natural y espiritual. Podemos decir, pues, que toda cosa es posible e imposible, ya que no es sino la unidad de atracción y repulsión.
} 
contradictorio y, en consecuencia, pueda ser efectivo, no excluye el que no- $A$ sea de igual modo no contradictorio y, así, pueda ser igualmente efectivo. Entendida de esta manera, la posibilidad contiene la incertidumbre de que si $A$ es sólo posible, entonces no- $A$ también es posible. El mismo movimiento reflexivo que hace pensable $A$, hace pensable, al mismo tiempo, no- $A$ :

La posibilidad es la referencia de comparación entre ambas [entre $A$ y no$A]$; lo que ella contiene dentro de su determinación - al ser ésta una reflexión de la totalidad - es el hecho de que también lo contrario sea posible. Ella es, por consiguiente, el fundamento que establece la referencia de que, en virtud de que $\mathrm{A}=\mathrm{A}$, entonces $-\mathrm{A}=-\mathrm{A}$; en el $\mathrm{A}$ posible está contenido también el posible no A; y es esta referencia misma la que determina a los dos como posibles. ${ }^{143}$

En la posibilidad formal, el movimiento reflexivo que permite pensar $A$ como posible, es el mismo que permite pensar a su opuesto no- $A$ como igualmente posible. La posibilidad formal está aquí frente a una tautología que consiste en un vaivén, en un ir y venir, de lo posible a lo también posible (si $A$ es definido como meramente posible, entonces no- $A$ es también posible). En tanto sólo se pasa de una posibilidad a otra, ambas se presentan igualmente posibles, con lo cual se cae en una completa y pura indeterminación donde se desconoce cuál es realmente posible (ya que si ambas se declaran con igual posibilidad, hemos visto que el resultado es su imposibilidad); lo cual genera, a su vez, una constante incertidumbre.

No obstante, con el fin de no permanecer en una incesante incertidumbre y de no quedarse en la pura indeterminación, donde toda posibilidad es eliminada ${ }^{144}$, se ha de determinar cuál de ellas es posible en realidad. Pero en tanto la posibilidad de toda cosa viene determinada por las relaciones reales que la determinan como tal, entonces la determinación de lo

\footnotetext{
${ }^{143}$ G. W. F. Hegel, Ciencia de la lógica (Madrid: Abada, 2011), p. 607.

${ }^{144}$ El demostrar que una y otra cosa son posibles, no conduce sino al vacío: si algo es meramente posible, su opuesto también lo es.
} 
que es realmente posible sólo puede venir por dichas relaciones concretas en las que se sostiene (son sólo las relaciones reales que determinan una cosa las únicas que la pueden definir como realmente posible). Así, la resolución de la determinación de aquello que es efectivamente posible anuncia ya el momento real de las modalidades, que deja atrás el momento meramente formal.

No obstante, antes que pasar al momento real, el pensamiento formal trata de resolver la contradicción que suscitó la modalidad de lo formalmente posible (y que por sí misma se mostró incapaz de enfrentar dicha contradicción y darle solución). Pero en tanto la contradicción que entraña lo puramente posible no puede ser resuelta desde sí misma, sólo podrá ser superada por su referencia a lo efectivo (la misma categoría de posibilidad contiene la exigencia de ir más allá de la mera posibilidad formal y pasar a la consideración de lo efectivo), por lo que el pensamiento formal se ve obligado a replantear la noción misma de posibilidad. Al repensar dicha noción, la posibilidad será considerada ahora como unida a lo efectivo, y no ya como algo contrapuesto.

Cuando lo posible y lo efectivo son considerados como algo separado, entonces cualquier cosa puede ser considerada con independencia de las relaciones reales que la fundamentan $\mathrm{y}$, en consecuencia, puede ser tenida como formalmente posible, ya que no es sino idéntica a sí misma. En efecto, cualquier cosa puede ser definida como formalmente posible siempre y cuando se le considere con independencia de las relaciones efectivas en las que es dada al pensamiento, pero en tanto se trata de una mera posibilidad abstracta, se ve llevada a su contrario. Pero con el fin de dar solución a la contradicción que contiene la mera posibilidad formal y determinar aquello que es realmente posible, la reflexión recurre a lo real, ya que sólo lo real puede indicar la presencia efectiva de lo posible. De acuerdo con Hegel, lo realmente posible se 
encuentra necesariamente sujeto a lo real, a los hechos brutos: $<<$ todo lo que es posible, por consiguiente, tiene en suma un ser o una existencia $>>.145$

La posibilidad es traída, así, al ámbito de lo existente, ya que si no se cuenta con un dominio efectivo que establezca aquello que es efectivamente posible, entonces toda posibilidad aparece como una mera indeterminación. Para determinar que algo es posible (o imposible) se requiere, pues, de un campo efectivo que lo determine como tal. La única manera de determinar si algo es posible (o imposible) es abandonar la posibilidad meramente formal, ya que lo simplemente formal es insuficiente para establecer las condiciones efectivas de aquello que se pretende efectivamente posible.

Pensar a fondo lo posible exige pasar del plano formal al plano real, y la única manera de hacerlo es introduciendo en ese formal un contenido: lo efectivo. Al introducir lo efectivo, se puede precisar si algo es meramente posible o, en cambio, si es efectivamente posible. La posibilidad efectiva de una cosa sólo podrá ser determinada por lo que efectivamente es el caso, por las condiciones efectivas que la determinan; de modo que el dominio de lo efectivo constituirá el criterio para determinar lo efectivamente posible. Únicamente porque lo efectivo existe se sabe que no todo ocurre, que hay ciertas cosas que no se dan en lo existente. Se requiere precisar entonces un campo de lo efectivamente posible.

El pensamiento retoma, así, la efectividad de la que había partido su reflexión en el momento formal, pero se trata ahora, a diferencia de aquella realidad inmediata y no reflexionada, de una realidad efectiva mediada por la posibilidad: <<Esta realidad efectiva no es la primera, sino la reflexionada, puesta como unidad de ella misma y de la posibilidad. Lo realmente efectivo, en cuanto tal, es posible; está en inmediata identidad positiva con la

\footnotetext{
${ }^{145}$ Ibíd., p. 608.
} 
posibilidad>>.146 Existe, pues, una unidad entre efectividad y posibilidad. En este momento formal, lo posible no es sino el reflejo de la efectividad en su pura identidad formal, por lo que la reflexión determina, a su vez, esta efectividad formal como el reflejo de la mera posibilidad. Considerada en su mera inmediatez, la realidad efectiva conduce a pensarla abstractamente como una pura posibilidad, pero una vez pensada como meramente posible, surge la exigencia de pensar su posibilidad efectiva, y no solamente su posibilidad formal.

El pensamiento ha introducido entonces lo efectivo en el dominio de lo formalmente posible, pero aunque la posibilidad posee ya un contenido, en cierto sentido permanece aún en el ámbito formal. Su permanencia en el ámbito formal, se debe a que el pensamiento realiza aquí una relativa separación entre el plano lógico y el mundo efectivo, otorgándole a este último una existencia independiente de aquél. En otras palabras, el pensamiento le otorga al mundo una consistencia efectiva independientemente de las formas de reflexión, con lo que lo considera como algo posible entre otros mundos posibles.

Pero en tanto el mundo efectivo se revela aquí como algo meramente posible y, por tanto, como algo que es de la misma manera que pudo no ser, es considerado como contingente ${ }^{147}$, pues lo contingente se define justo como aquello que podría ser de otro modo ${ }^{148}$. La contingencia es para Hegel la unidad entre posibilidad y efectividad: <<Esta unidad de la posibilidad y la realidad efectiva es la contingencia>>.149 Lo efectivo resulta aquí contingente, ya que en tanto sólo posee la característica de haber sido posible, también su opuesto podría haber sido posible. En tanto su opuesto pudo igualmente haber existido,

${ }^{146}$ Ibíd., p. 607.

${ }^{147}$ El pensamiento transita así de lo formalmente posible a lo formalmente contingente.

${ }^{148}$ La contingencia <<es una existencia que no tiene más valor que el de una posibilidad, algo que tanto es como como podría igualmente no ser〉>. G. W. F. Hegel, Enciclopedia de las ciencias filosóficas (Madrid: Alianza, 1999), pp. 106-107.

${ }^{149}$ G. W. F. Hegel, Ciencia de la lógica (Madrid: Abada, 2011), p. 608. 
la forma de la realidad efectiva pudo haber sido de otro modo... la efectividad se presenta como pura contingencia: $<<$ Lo contingente es un [ser] realmente efectivo, determinado al mismo tiempo solamente como un ser posible cuyo otro o contrario es [o existe, y] precisamente en la misma medida $>>.150$

En tanto lo efectivo sólo se ha determinado aquí como un posible entre otros, en tanto no es sino una mera posibilidad, se presenta como algo contingente (la posibilidad, al ser la efectividad meramente interna es también, por ello, la efectividad meramente externa, o sea, contingente). Lo contingente es, pues, lo que puede ser o también no ser, aquello que puede ser de este modo o de otra manera (es decir, aquello cuyo ser o no ser, no está fundamentado dentro de sí, sino dentro de otro). ${ }^{151}$ Pero cabe mencionar que la realidad efectiva aparece como contingente cuando el conjunto de relaciones que le determinan no ha podido ser completamente precisada. Si su existencia no se ha definido plenamente, lo efectivo, se dirá, podría no haberse presentado a la existencia.

Si bien, lo contingente existe, pudo no haberlo hecho. En este sentido, lo contingente tiene un fundamento (o de otra manera no se presentaría en la existencia), pero al mismo tiempo carece de él (o de otra forma no tendría un carácter casual): $<<$ Que lo contingente no tenga por tanto ningún fundamento se debe a que es contingente; $y$, en la misma medida, que tenga ciertamente un fundamento se debe a que es contingente>>.152 En este momento de contingencia, el decir que lo efectivo es efectivo por haber sido posible, carece de fundamento, ya que en tanto mera posibilidad, pudo haber sido diferente. Pero por otra parte, para ser efectivo, lo efectivo mismo tuvo que haber sido posible, por lo que su propia posibilidad constituye su fundamento; fundamento que, en

${ }^{150}$ Loc. cit.

$151<<$ Being just the inwardness of actuality, possibility is, precisely for that reason, merely external actuality or contingency as well [...] We consider the contingent, therefore, as what either can be or can also not be, as what can be thus or otherwise too, i. e., as that whose being or not being, being thus or otherwise, is grounded not within itself but in another〉>. G. W. F. Hegel, The Encyclopaedia Logic (IndianapolisCambridge: Hackett Publishing Company, 1991), p. 218.

${ }^{152}$ G. W. F. Hegel, Ciencia de la lógica (Madrid: Abada, 2011), p. 609. 
tanto sujeto a la posibilidad, depende de otro, de sus relaciones efectivas. De ahí que lo contingente a la vez que posee un fundamento, carece del mismo.

Cualquier cosa tomada en su singularidad aparece como contingente, pues para ser, requiere de su otro, y en tanto el fundamento de su existencia depende de otro (en tanto éste reside fuera de sí misma), representa una existencia que también pudo no haber existido. En general, lo contingente es, de acuerdo con Hegel, aquello que tiene el fundamento de su existencia, no dentro de sí, sino dentro de otro. La contingencia es la primera forma [Gestalt] en la que se presenta la realidad efectiva ante la consciencia; forma que, sin embargo, es frecuentemente confundida con la realidad efectiva propiamente dicha. Pero desde el punto de vista de la reflexión, lo contingente es sólo realidad efectiva de un modo unilateral, esto es, cuando dicha realidad es considerada como algo meramente posible. 153

Como se puede observar, la contingencia contiene tanto la posibilidad como la efectividad. Lo contingente, aunque pudo no ser, ya es algo efectivo, por lo que la noción misma de contingencia implica la noción de realidad efectiva. Esto muestra que no todo es posible, únicamente aquello que es realmente efectivo puede ser efectivamente posible, y la realización de esta posibilidad es lo contingente (es decir, la relativa identificación entre lo posible y lo efectivo), pues se trata de una existencia que, aunque efectiva, es sólo una posible entre otras. Pero la contingencia de lo realmente efectivo sólo puede hacerse manifiesta comparándole con aquellas otras posibles alternativas que, en tanto tales, también podrían haberse realizado. En la determinación de la contingencia, el pensamiento permanece dependiente de lo que le es ofrecido exteriormente (admite todavía un algo externo, algo dado), pues se atiene a lo existente para diferenciarlo de lo meramente posible. Así, la contingencia se

\footnotetext{
$153<<$ The contingent is generally what has the ground of its being not within itself but elsewhere. This is the shape in which actuality first presents itself to consciousness, and which is frequently confused with actuality itself. But the contingent is only the actual in the one-sided form of reflection-into-another or the actual considered as what is merely possible>>. G. W. F. Hegel, The Encyclopaedia Logic (IndianapolisCambridge: Hackett Publishing Company, 1991), p. 218.
} 
debe a una relativa independencia entre el ser y el pensar (en lo contingente existe todavía una separación entre el pensamiento que determina la posibilidad de la cosa y la existencia efectiva que determina la realidad de la misma). ${ }^{154}$

A pesar de que, como se ha dicho, la contingencia representa ya una cierta unidad entre la efectividad y la posibilidad, mantiene aún una cierta separación. ${ }^{155}$ Estrictamente hablando, lo efectivo constituye sólo una parte del amplio dominio de lo posible, lo cual hace factible que dos cosas contrapuestas sean pensadas a la vez como igualmente posibles. De ahí que cuando una de ellas se presenta efectivamente en la existencia, se cae en la cuenta de que podría haber sido de otra manera (que en vez de tal cosa, podría haberse presentado su opuesta), con lo que su misma presencia, en tanto mera posibilidad, es considerada como algo enteramente contingente.

Pero en este ámbito de lo contingente, así como la realidad efectiva ya no es aquí, como lo fue en un primer momento, una realidad inmediata - no reflexionada - la posibilidad no es ya tampoco una posibilidad inmediata, sino que se trata ahora de una posibilidad reflexionada — reflejada - desde la realidad efectiva. La posibilidad se refleja como la realidad efectiva de dicha posibilidad, como la realización de la misma. La posibilidad no puede realizarse sino como una cierta realidad efectiva, la cual no puede ser sino la realización de su propia posibilidad. De ahí que, en la unidad mediada de posibilidad y efectividad, ya no se trata de algo meramente posible, sino de un cierto posible:

Así la realidad efectiva, dentro de su unidad inmediata con la posibilidad, es solamente la existencia, y está determinada como un ser carente de

\footnotetext{
${ }^{154}$ Lo contingente, en tanto puede ser como también no ser, no resulta susceptible de deducción racional (lo contingente únicamente podría ser racionalmente deducido postulando un orden necesario ya sea natural o divino que pudiera explicar su presencia).

${ }^{155}$ Aunque cada una de estas categorías (posibilidad y efectividad) encuentra su significación sólo a través de la otra (la posibilidad es sólo tal a través de lo efectivo, y lo efectivo no es sino por su posibilidad) son puestas en este momento una frente a la otra. No se trata todavía aquí, en tanto contingencia, de la completa mediación donde una y otra se identifican, sino simplemente de la contraposición inmediata en la que cada cual otorga sentido a la otra en tanto categorías opuestas.
} 
fundamento que es solamente un ser puesto, o sea, sólo posible; o bien, en cuanto reflexionada y determinada respecto a la posibilidad, está entonces separada de la posibilidad, del ser-reflexionado-dentro-de-sí y, con ello, es igual de inmediatamente, también, sólo un ser posible>>. ${ }^{156}$

A diferencia de lo que ocurría anteriormente, la unidad entre posibilidad y efectividad es ahora una unidad mediata (esto es, mediada por la reflexión). La realidad efectiva ya no es "sólo posible" (algo meramente pensable), sino "un ser posible" que, aunque posible, ya es. En tanto la efectividad inmediata es sólo posible, su opuesto también es posible, por lo que resulta contingente. En cambio, la efectividad reflexionada es ya un ser, cuya condición de existencia fue el haber sido posible. La posibilidad es la única condición necesaria para que lo efectivo devenga tal, lo efectivo sólo es efectivo debido a su posibilidad.

Lo contingente, en tanto se trata de algo efectivo que depende de haber sido posible para su realización, consiste en la unidad entre efectividad y posibilidad, pero justo esta posibilidad hace de dicha unidad algo inmediato, pues otra cosa también habría resultado posible. Empero, la presencia de lo efectivo muestra la realización de su posibilidad, y en tanto se trata de su propia posibilidad (en tanto fue ella, y no otra, la que al fin y al cabo se realizó), entonces ese efectivo se muestra como necesario, pues no podría haber sido de otra manera; o de lo contrario, su propia posibilidad no se hubiese realizado (se hubiera realizado otra, que al no ser la suya propia, tendría que haberse dado de otra manera). Es necesaria la realización de su propia posibilidad para que un efectivo devenga justo ese efectivo, y no otro.

Así, aunque en un primer momento la realidad efectiva se muestra ante el pensamiento como contingente; en un segundo momento, en tanto tiene como fundamento la realización de su propia posibilidad, la realidad efectiva se muestra como un ser plenamente estable y, en consecuencia, como necesario: $<$ Lo contingente es, pues, necesario porque lo realmente efectivo está

${ }^{156}$ G. W. F. Hegel, Ciencia de la lógica (Madrid: Abada, 2011), p. 609. 
determinado como posible, con lo que su inmediatez está asumida [...] así es como es necesario también porque esta posibilidad suya [...] está sencillamente asumida y puesta como ser $>>.157$ Esta aparente estabilidad del ser causa que el pensamiento caiga insistentemente en la comodidad de no determinarle más, rindiéndose frente a lo contingente y declarándole como necesario. ${ }^{158}$

En tanto lo contingente es (existe) ya de cierta manera -aunque también (posiblemente) pudo ser de otro modo, esto es, aunque sólo sea como la realización de un posible entre otros-, inmediatamente se admite como necesario. En efecto, el pensamiento formal cae en la pereza y se satisface en declarar lo contingente como necesario: porque es, es necesario. Toma la fácil resolución de declarar su necesidad con base en su pura existencia. En este momento formal, todo aquello que es efectivo, en tanto se trata sólo de un posible, resulta contingente; pero en tanto esta contingencia ya es, tiene una existencia, entonces es considerada como necesaria, pues es ya de un cierto modo, y no de otro. ${ }^{159} \mathrm{Su}$ posibilidad y efectividad coinciden, pues ésta no es sino la realización de aquélla.

Así, mientras la unidad inmediata de posibilidad y efectividad viene a ser la contingencia; la unidad mediata (reflexionada) entre ambas, en la que existe una entera determinación recíproca, se convierte en necesidad: $<<$ Esta inquietud absoluta del devenir de estas dos determinaciones es la contingencia. Pero como cada una se vuelca inmediatamente en la contrapuesta, coincide entonces, dentro de ésta, consigo misma de la misma y sencilla manera; y esta identidad de ellas, de la una dentro de la otra, es la necesidad>>.160 En la

\footnotetext{
157 Ibíd., p. 609.

${ }^{158} \mathrm{El}$ pensamiento formal se conforma aquí con presentar aquello que es sólo formalmente contingente como algo formalmente necesario.

${ }^{159}$ Dentro de este momento formal todo aparece como posible o contingente, pero definido un dominio efectivo, esta contingencia se presenta determinada como aquello que se sigue necesariamente de ese dominio; y en cuanto tal, en cuanto no es sino de ese modo, es tenida por el pensamiento formal como algo necesario.

${ }^{160}$ G. W. F. Hegel, Ciencia de la lógica (Madrid: Abada, 2011), p. 609.
} 
necesidad, lo posible y lo efectivo ya no se identifican sólo relativamente, como ocurría en la contingencia, sino que logran una completa identidad.

Lo efectivo para ser lo que es, necesariamente tuvo que haber sido posible, y en tanto posible, pudo haber sido de otra manera. Lo efectivo es entonces contingente: ciertamente se presenta como siendo lo que es, pero en tanto es como es, y no de otra manera, entonces se muestra como habiendo devenido justo lo que es, es idéntico consigo mismo. ${ }^{161}$ Esta identidad de la realidad efectiva muestra su necesidad, pues dicha realidad no se presenta meramente como lo que es, sino que además se muestra como habiendo devenido precisamente lo que es, y no otra cosa: <<Así la realidad efectiva, dentro de lo diferenciado de ella, o sea, dentro de la posibilidad, es idéntica a sí misma. Ella es, en cuanto esta identidad, necesidad $>>.162$ La unidad que en un primer momento había sido definida como contingencia, ahora se define como necesidad; lo que hasta hace un momento era definido como contingente ahora lo es como necesario. ${ }^{163}$

En sentido estricto, mientras que lo contingente es aquello que podría ser de otra manera, lo necesario es aquello que no sabe ser de otro modo. Pero, a pesar de ello, la contingencia y la necesidad no son realmente algo independiente: la contingencia sólo adquiere sentido a través de la necesidad, y la necesidad sólo toma sentido mediante la contingencia (algo efectivo puede ser considerado contingente sólo en tanto le subyace lo realmente necesario, y viceversa). De esta manera, contingencia y necesidad no se excluyen entre sí. La realidad efectiva reflexionada, como unidad de posibilidad y efectividad, es contingente y necesaria a la vez.

${ }^{161}$ En efecto, haber devenido lo que es, significa haber sido causa de sí mismo, y no causado por algo otro externo. Lo que es, es tal debido a sí mismo, se hace idéntico a sí mismo. Para que algo devenga él mismo (esto es, para que sea idéntico consigo), ha de ser mediado; nada deviene lo que es (ni puede ser idéntico consigo mismo) de modo inmediato, nada consigue su identidad en su inmediatez. En este sentido, lo efectivo sólo puede devenir él mismo, sólo puede ser idéntico a sí, en tanto viene mediado por lo posible.

${ }^{162}$ Loc. cit.

${ }^{163}$ Aparece aquí la modalidad de necesidad formal, la cual hace referencia a la unidad, no ya inmediata, sino reflexionada entre la posibilidad y la efectividad. 
Es la misma actividad reflexiva la que, en su esfuerzo por pensar la realidad efectiva, plantea la exigencia de transitar de lo posible a lo contingente y de esto a lo necesario; no obstante, en un acto de precipitación, el pensamiento formal confunde lo contingente con lo necesario, y cree otorgar la prueba de la necesidad del ser al declarar que: <<lo necesario es; y este ente es él mismo lo necesario>>.164 Pero aquí el pensamiento formal no ha escapado a las tautologías, pues en el ir y venir de lo efectivo a lo posible y de lo posible a lo efectivo, no ha hecho más que elevar (injustificadamente) lo contingente al rango de necesario. En el momento en el que admite que existe una correspondencia inmediata entre el ser y el pensar, la reflexión se rinde frente a lo que se le ofrece como contingente sin haber podido determinarle plenamente como tal y le admite como necesario; se conforma con esa contingencia y la considera necesaria por la simple razón de que existe. Bajo esta postura se concluye que basta con reflexionar en torno a lo que es dado como contingente para hallar la necesidad de su existir.

Existe entonces en el pensamiento formal una pretensión de establecer lo necesario a partir de lo dado. Pero para nuestro filósofo el pretender establecer lo inmediatamente dado como necesario equivale a pretender elevar las determinaciones inmediatas del ser (los accidentes) a la dignidad de fundamento (sustancia). Para el pensamiento especulativo lo meramente contingente no satisface las exigencias de síntesis de la unidad reflexiva, cuya meta es justo reducir la contingencia y elevarse a la necesidad. Pero, si bien el pensamiento no puede conformarse con lo contingente, no puede, por ello, tildar de inmediato como necesario todo cuanto es.

De hecho, el que el formalismo considere todo lo que es como necesario, constituye para Hegel una verdadera resignación del pensamiento, pues con ello éste renuncia a sus propias exigencias. De modo que si el pensamiento no quiere renunciar a sí mismo, debe seguir su propio movimiento reflexivo. $\mathrm{Y}$ es

\footnotetext{
${ }^{164}$ Loc. cit.
} 
justo la vaciedad del pensamiento formal la que exige la aparición de otras determinaciones; determinaciones contenidas ya, por cierto, en el mismo movimiento de la reflexión y cuya tarea será sólo la subsunción de las anteriores como algo todavía insuficiente para pensar la realidad efectiva, pues dicho movimiento reflexivo consiste en una progresión inmanente de las propias determinaciones lógicas.

Así, frente al mero formalismo del pensamiento, Hegel recurre a lo efectivo para darle movilidad, pero no se trata de un efectivo meramente externo, sino que hace de él un momento interno a la propia reflexión. Al introducir lo efectivo en el terreno del pensamiento surge la exigencia de abandonar el mero formalismo. Enseguida el pensamiento va a superar el plano meramente formal, y pretenderá ahora pensar lo efectivo a través del conjunto de determinaciones contrapuestas que aparecen como su contenido inmediato. Al tratar de pensar la realidad efectiva, el pensamiento se enfrenta a una multiplicidad de determinaciones que se manifiestan en su realidad, y mediante las cuales ha de tratar de reconstituir su unidad. En cuanto se asoma esta multiplicidad de lo real para reconducirla a su unidad, el pensamiento sale del ámbito meramente formal y alcanza el momento real.

\section{Momento real}

Hemos visto que el primer momento de la reflexión sobre las modalidades corresponde a las determinaciones "formales" del pensamiento. Pero el segundo momento corresponderá a las determinaciones "reales" del mismo, esto es, a la "Necesidad relativa, o real realidad efectiva, posibilidad y necesidad reales". Este segundo momento se ve encabezado por la noción de "necesidad relativa", ya que constituye el resultado que se consigue del proceso formal del pensamiento: <<La necesidad que se ha dado como resultado es formal porque sus momentos son formales, o sea determinaciones simples que 
sólo son totalidad como unidad inmediata, es decir como un inmediato volcarse el uno dentro del otro, sin tener por ende figura de subsistencia de suyo >>.165

Recordemos que el momento formal termina ya con la modalidad de necesidad, pero se trata sólo de una necesidad formal (o relativa), ya que la cosa pensada es declarada como necesaria sin que exista todavía una plena unidad entre la multiplicidad de sus determinaciones y la unidad reflexiva del pensamiento, se trata sólo de una unidad inmediata entre dos momentos de suyo independientes. La reflexión formal presupone al propio pensamiento y a la cosa pensada como si ambos fuesen algo dado de antemano, donde el primero establece las condiciones determinantes de la segunda. En cambio, en el momento real de las modalidades, la cosa no se muestra a la reflexión como un dato al que el pensamiento deba imprimirle un orden condicionante desde sí mismo, sino que se presenta como algo ya pensado (o reflexionado) en sus determinaciones constitutivas. En tanto la cosa se presenta constituida por sus determinaciones pensadas, ella misma es ya pensamiento.

Así, mientras que en un primer momento de la figura formal, lo efectivo aparecía como algo inmediato todavía no reflexionado, en la figura real lo efectivo es reconocido ya desde el inicio justo como reflexión. ${ }^{166}$ Este efectivo reflexionado es la realidad efectiva real (real Wirklichkeit), la cual se muestra como una multiplicidad de propiedades, como una existencia efectiva que es efectivamente reflexionada: <<La real realidad efectiva, en cuanto tal, es por lo pronto la cosa de muchas propiedades, el mundo existente; pero no la existencia, que se disuelve en la aparición, sino que, en cuanto realidad efectiva, es al mismo tiempo ser en sí y reflexión-dentro-de-sí; se conserva en la multiforme variedad de la mera existencia; su exterioridad es un

\footnotetext{
${ }^{165}$ Ibíd., p. 610.

${ }^{166}$ En un primer momento: <<La realidad efectiva es formal en la medida en que, al ser realidadefectiva primera, es sólo inmediata, no reflexionada, con lo que no hace sino estar en esta determinación-deforma, pero no como totalidad de la forma〉>. Ibíd., p. 605. Aunque en un segundo momento: <<Esta realidad efectiva no es la primera, sino la reflexionada, puesta como unidad de ella misma y de la posibilidad〉. Ibíd., p. 607.
} 
comportamiento-y-relación interior, sólo para consigo misma>>.167 La efectividad real se presenta como una multiplicidad de determinaciones aprehendida por la reflexión (y es sólo la reflexión la que puede otorgar cierta aprehensión de la multiplicidad contenida en la cosa pensada). La realidad realmente efectiva de una cosa se refiere a la unidad de las condiciones o determinaciones reales que la constituyen como tal. ${ }^{168} \mathrm{El}$ mundo es una realidad realmente efectiva en la medida en que sea constituido como una multiplicidad de determinaciones unificada por el movimiento de la reflexión.

La realidad efectiva real se refiere al mundo existente que es reflexionado como mundo realmente efectivo, y no como algo inmediato cuya existencia se pueda diluir en una mera posibilidad (en una pura "reflexióndentro-de-sí”). Lo efectivo real se halla en el mundo existente, por lo que se encuentra en relación con otros, se trata de un efectivo real que siempre se halla relacionado en el mundo. De ahí que Hegel hablará ahora de realidades (Wirklichkeiten), en plural:

Lo que es realmente efectivo [o sea lo que está en acto] puede actuar [e.d. producir efectos]; su realidad efectiva da razón de algo por aquello que él produce. Su comportamiento-y-relación a otro es manifestación de sí; no es una transición —así es como se refiere el algo que es un ente a otroni un aparecer —así es como está la cosa, sólo en relación a otras—; es un ser subsistente de suyo, pero teniendo tiene su reflexión-dentro-de-sí, o sea su esencialidad determinada, dentro de otro subsistente de suyo. ${ }^{169}$

Lo efectivo real, en tanto se encuentra en relación con otros, produce un efecto sobre los mismos, y la constatación de su realidad viene dada justo por el efecto que genera en ellos. En su relación con estos otros, lo efectivo real no se

${ }^{167}$ Ibíd., p. 610.

${ }^{168} \mathrm{Si}$ la reflexión no considera a la cosa constituida por la unidad de sus determinaciones reales y, por el contrario, la toma fuera de las mismas, entonces la cosa es pensada no como realmente efectiva sino sólo como formalmente efectiva. Algo es formalmente efectivo cuando no es completamente determinado por sus condiciones reales de existencia, pero en el momento el que alcanza tal determinación, se convierte en algo realmente efectivo.

${ }^{169}$ Loc. cit. 
transforma en $\multimap$ transita a-otra cosa, ni se disuelve frente a ellos, sino que se manifiesta en medio de la relación misma, ya que todo lo efectivo real es subsistente de suyo, subsiste en sí mismo. Pero esta subsistencia, paradójicamente, depende de otro, pues tiene su propia esencia "dentro de otro subsistente de suyo".

Ninguna realidad efectiva es por sí misma, su identidad depende de $s u$ otro. Toda realidad efectiva real, al consistir en una multiplicidad de propiedades, requiere de esta misma multiplicidad para ser definida como efectivamente real. Por consiguiente, cuando se piensa en una cosa sin contradicción, se puede declarar a la misma como posible, pero será meramente posible hasta que no se defina la multiplicidad de condiciones, circunstancias y determinaciones que la hagan realmente posible (para que la realidad efectiva real deviniera lo que es, tuvo que haberse dado una multiplicidad de cuestiones que lo hicieran realmente posible): $<<$ La posibilidad real de una cosa es por consiguiente la multiforme variedad de circunstancias que están ahí, que se refieren a ella $>>.170$

Observamos que, mientras en la figura formal, para ser lo que es, lo efectivo requería el haber sido posible; en la real, lo efectivo, para devenir lo que es, requiere de la multiplicidad de propiedades que lo conforman, esto es, requiere ser realmente posible. La única condición para que lo efectivo real haya devenido lo que es, consiste en el hecho de haber sido realmente posible, y esta posibilidad real consiste en la presencia de una cierta multiplicidad de condiciones, circunstancias y determinaciones que lo constituyen justamente como ese efectivo. Mientras que la única condición para que lo efectivo formal sea lo que es, se basa en el haber sido formalmente posible; posibilidad formal que, como se ha dicho, consiste en no ser contradictorio consigo mismo:

${ }^{170}$ Ibíd., p. 611. En tanto son las determinaciones reales de la cosa, las que definen la posibilidad real de la misma, la reflexión se ve llevada a considerar lo real como un elemento constitutivo en la determinación de lo realmente posible. Con lo cual tiene que abandonar la definición puramente formal y pasar a la modalidad de posibilidad real. 
La posibilidad formal es la reflexión-dentro-de-sí solamente como la identidad abstracta de que algo no se contradiga dentro de sí. Sin embargo, en la medida en que se compromete uno con las determinaciones, circunstancias y condiciones de una Cosa, para conocer a partir de ello su posibilidad, se deja de estar entonces cabe la posibilidad formal, tomando en cambio en consideración su posibilidad real. ${ }^{171}$

La primera modalidad con la que el pensamiento trata de hacer inteligible la realidad realmente efectiva es la posibilidad real. En este momento, la posibilidad real se refiere al esfuerzo del pensamiento por aprehender una determinada cosa a partir de sus determinaciones reales, las cuales no son sino sus condiciones constitutivas de existencia. La posibilidad real de una cosa está fundada en la determinación de aquella multiplicidad de propiedades que la constituyen justo como cosa. Esta modalidad no se remite, pues, sino al conjunto de determinaciones, circunstancias y condiciones que el pensamiento halla como constitutivas de la cosa pensada.

Bajo esta concepción cabe resaltar dos aspectos. Por una parte, la posibilidad real de una cosa — como totalidad de sus condiciones-, se presenta como una multiplicidad de determinaciones que puede ser considerada con independencia de su unidad en la cosa y, por tanto, como algo abstracto: $<<$ Es verdad que [... la posibilidad real] es ahora el todo de la forma, puesto; pero de la forma dentro de su determinidad, o sea de la realidad efectiva en cuanto formal o inmediata y, en la misma medida, de la posibilidad, entendida como abstracto ser en sí>>. ${ }^{172}$ La posibilidad real contiene, así, todavía un aspecto formal, ya que se trata de una existencia inmediata, donde lo efectivo real se encuentra disperso en su multiplicidad, se trata de una efectividad carente de unidad (eine zerstreute Wircklichkeit).

\footnotetext{
${ }^{171}$ Loc. cit.

${ }^{172}$ Loc. cit.
} 
Sin embargo, por otra parte, la posibilidad real de una cosa —en tanto el todo de sus condiciones - no puede ser definida con independencia de cuya cosa es justo posibilidad. La posibilidad real únicamente puede ser definida en relación a la cosa que precisamente fue definida como posible: <<Así, la posibilidad real constituye el todo de condiciones, una realidad efectiva dispersa, no reflexionada dentro de sí, pero que está determinada [, destinada y a la vez dispuesta] a ser el ser en sí, pero de otro, ya deber regresar a sí>>.173

Hegel muestra, por un lado, que la posibilidad real (totalidad de condiciones) puede ser pensada como teniendo una existencia independiente con respecto a la cosa pensada; y, por otro lado, muestra que la posibilidad real sólo es como tal en relación a la cosa pensada de la que precisamente constituye su posibilidad. Sólo en tanto la cosa es realmente efectiva, se puede pensar $s u$ posibilidad real (sólo en tanto la posibilidad lo es de algo real, se puede pensar la posibilidad real). La posibilidad real de la cosa es plenamente definida por la totalidad de sus condiciones constitutivas, las cuales dejan de existir como tales si se les considera con independencia de aquella cosa a la que constituyen (pues si son condiciones, entonces por definición lo tienen que ser de algo; una condición sólo se define con respecto a lo que condiciona).

La posibilidad real se refiere, pues, a la unidad de la cosa con sus condiciones; no se refiere más que a las determinaciones que constituyen a una cosa como tal. No obstante, en tanto las determinaciones que constituyen una cosa son siempre opuestas entre sí, se requiere definir un fundamento que permita reunir, aun en su oposición, la multiplicidad de determinaciones contrapuestas dentro de la cosa. Pero este fundamento que no se puede hallar sino en el conjunto mismo de determinaciones que constituyen la cosa como tal.

El fundamento de una cosa no se encuentra, pues, sino en las condiciones propias de su existencia. Hay aquí una indisociabilidad de la cosa con sus

\footnotetext{
${ }^{173}$ Loc. cit.
} 
condiciones. En este sentido, la posibilidad real identifica la presencia de las condiciones con la presencia de la cosa. Esto le permite decir a Hegel que $<<$ cuando todas las condiciones de una Cosa están completamente presentes, entra ésta entonces dentro de la realidad efectiva: la completud de condiciones es la totalidad como estando en el contenido, y la Cosa misma es este contenido, determinado [y destinado] a ser tanto algo realmente efectivo como algo posible>>.174 En el momento en que el conjunto entero de condiciones de una cosa se halla presente, entonces ella es ya realmente efectiva, pues dicha cosa no es sino la unidad de tales condiciones. La realización de su posibilidad real, deriva en la realidad realmente efectiva de la cosa.

La posibilidad real, se refiere a la relación entre las condiciones y la cosa (o entre el conjunto de determinaciones y su reunión en la cosa), pero no se trata de una mera relación externa entre lo condicionante y lo condicionado, donde mediante un proceso de prueba y error se consiga el sistema condicionante de una cosa; esto es, donde la cosa es determinada por una serie de condiciones independiente de la misma. No se trata de la mera reconducción de lo condicionado a la serie de condiciones externas que le determinan como algo ajeno, sino que se trata de una relación en la que las condiciones determinantes de la cosa la constituyen como tal, pues sin ellas dicha cosa carecería de consistencia alguna. $\mathrm{Y}$ en tanto viene enteramente constituida por las mismas determinaciones, la cosa no es considerada sino como la totalidad de sus condiciones (como el todo de sus propias determinaciones). De este modo, la posibilidad real se basa, no en una relación entre lo condicionante y lo condicionado, sino más bien en una relación símil a la efectuada entre el fundamento y lo fundamentado. Pero se trata esta vez de un momento todavía más concreto de la reflexión:

${ }^{174}$ Ibíd., p. 612. La misma idea se encuentra al cierre de la sección en torno a "La condición" dentro del capítulo sobre "El fundamento", ahí Hegel aduce: <<Cuando todas las condiciones de una Cosa están presentes, entra entonces en la existencia (ein Hervortreten, das einfache sich Herausstellen in die Existenz)>>. Ibíd., p. 533. 
En la esfera del fundamento condicionado, las condiciones tienen la forma —o sea, el fundamento o la reflexión que es para sí- fuera de ellas, siendo ésta la que las pone en referencia con momentos de la Cosa y engendra en ellas la existencia. Aquí, por el contrario, la inmediata realidad efectiva no está determinada a ser condición por una reflexión presuponente, sino que lo puesto es que ella misma es la posibilidad. ${ }^{175}$

Cabe mencionar que, la posibilidad real, al igual que la posibilidad formal, es definida como contradicción, pues si lo posible es sólo una posibilidad, entonces deja de ser posible y se torna también imposible: $<<$ Pero [... la contradicción] no es empero una contradicción de la comparación, sino que la existencia multiformemente variada es en sí misma esto, asumirse e irse al fondo [, al fundamento]; y allí es donde tiene esencialmente en ella misma la determinación de ser solamente algo posible>>. ${ }^{176}$ Algo solamente es realmente posible si se piensa como realidad efectiva real, de este modo, pensar la posibilidad real de una cosa, es pensar la efectividad real de la misma.

La posibilidad formal había ya también caído en esta contradicción, donde al afirmar algo como meramente posible resultaba de hecho imposible. Contradicción que en ese momento sólo podía tener solución introduciendo lo efectivo en el ámbito formal, con lo que lo posible y lo efectivo, que anteriormente habían sido considerados como contrapuestos entraban en íntima relación. En la posibilidad real aparece esta misma contradicción, pero ahora de forma más concreta, pues no se trata ya de aquella tautología en la que se movía la reflexión formal, esto es, de aquel ir y venir de lo posible a lo efectivo, y viceversa. No se trata de pasar de lo meramente posible a lo realmente efectivo, sino de la diseminación de la cosa en sus condiciones constitutivas y su posterior reconstitución en la unidad de la misma (en otros términos, se trata de ir de lo fundamentado a la fundamentación, y de regresar de nuevo a lo fundamentado).

\footnotetext{
${ }^{175}$ Ibíd., p. 612.

${ }^{176}$ Ibíd., p. 612.
} 
La unidad de la cosa y las condiciones o, por así decirlo, de lo fundamentado y el fundamento viene dada por el proceso reflexivo que funge como mediación entre dos instancias que aparecen como opuestas. La reflexión es la encargada de mediar la tensión entre la multiplicidad y la unidad. Empero, aunque se trata de una mediación, la unidad sólo puede existir a través de la multiplicidad, y la multiplicidad, a su vez, sólo puede existir por la unidad. La unidad de la cosa no existe fuera de su multiplicidad, y la multiplicidad no existe fuera de su unidad. Por decirlo de algún modo, la cosa es constituida en multiplicidad, y la multiplicidad en unidad.

Esto muestra que en realidad nunca hay una separación entre la cosa y las condiciones, ya que aquélla no es sino el producto de la unificación del todo de condiciones que la constituyen, mientras que éstas no son sino el resultado de separar a la cosa en sus determinaciones constitutivas. Pero sólo la reflexión es capaz de separar a la cosa en sus condiciones constitutivas y volver a reunirlas en su unidad constituida. ${ }^{177}$ En el momento en el que, con su capacidad de abstracción, la reflexión logra la determinación (o separación) de las condiciones constitutivas de la cosa, se refiere a la posibilidad real; mientras que en el momento en el que logra la configuración de la cosa como unidad de sus condiciones, se refiere a la efectividad real.

La posibilidad real conduce a la existencia inmediata de la cosa, es decir, a la multiplicidad dispersa de condiciones; mientras que la efectividad real reconduce tal multiplicidad a la unidad de la cosa como existencia mediada. La efectividad real es la reflexión que reconduce las condiciones a la cosa como un todo de relaciones que constituye justo su posibilidad real, por lo que ambas modalidades se identifican. Posibilidad real y efectividad real se identifican en tanto no son sino dos lados de un mismo proceso reflexivo, pero se diferencian

177 Si primero la cosa y sus condiciones se pueden mostrar como momentos separados y luego como unidad, es debido al trabajo reflexivo. Únicamente por medio de un proceso de análisis y síntesis la reflexión puede moverse de la cosa al conjunto de condiciones que la constituyen y de ahí nuevamente a su unidad determinada. 
en tanto corresponden a dos momentos distintos de dicho proceso. ${ }^{178}$ Mientras uno de estos momentos desmonta a la cosa en su multiplicidad de condiciones (posibilidad real), el otro reintegra, a su vez, esta multiplicidad en la unidad constituida de la cosa pensada (efectividad real).

La posibilidad real puede coincidir o identificarse con la efectividad real porque, a diferencia de la formal, es "un coincidir consigo misma". Esto significa que, como ya se ha dicho, cuando se presenta un cierto conjunto de condiciones que constituyen una determinada cosa (esto es, cuando se da la posibilidad real de la misma), entonces dicha cosa pasa a la realidad (es decir, la posibilidad real se convierte en efectividad real). Cuando se realizan o se cumplen las condiciones que componen una cosa, su posibilidad real deviene efectividad real; con lo cual la posibilidad real coincide consigo misma, pues lo efectivo que se realiza, no es sino la realización de la posibilidad real de ese efectivo. ${ }^{179}$ En este sentido, la posibilidad real queda subsumida desde sí misma, algo que no ocurría con la posibilidad formal, la cual requería de su otro para ser superada (recordemos que si una cosa es sólo formalmente posible, entonces también su otro es posible; de ahí que lo meramente posible, resulta también imposible, contiene una contradicción que le hace pasar a su otro, a lo efectivo, para determinar lo efectivamente posible):

Según la posibilidad formal, por el hecho de que algo era posible, era posible también no él mismo, sino su otro. La posibilidad real no tiene ya frente a sí un tal otro, pues ella es real, y en tal medida ella es también la realidad efectiva. Por tanto, al asumirse la existencia inmediata de la misma, el círculo de condiciones, ella se hace el ser en sí que ella misma es ya, a saber, como ser en sí de otro. Y en cuanto que, a la inversa, por

$178<<$ La real realidad efectiva tiene entonces igualmente en ella misma, de inmediato, la posibilidad. Contiene el momento del ser en sí; pero, al ser al principio solamente la unidad inmediata, está dentro de una de las determinaciones de la forma, y, por ende, al ser lo ente, está diferenciada del ser en sí, o sea de la posibilidad〉>. Ibíd., pp. 610-611.

$179<<$ La posibilidad que se asume a sí misma engendra por tanto los mismos momentos ya presentes, sólo que cada uno viene a ser ahora a partir del otro; por consiguiente, ella no es tampoco, en esta negación , un pasar, sino un coincidir consigo misma〉>. Ibíd., pp. 612-613. 
ello se asume al mismo tiempo su momento de ser en sí, se convierte en realidad efectiva, o sea en el momento que, igualmente, ella es ya. - Con ello, lo que desaparece es el hecho de que la realidad efectiva estaba determinada como posibilidad o ser en sí de otro, y a la inversa, la posibilidad como realidad efectiva que no es aquella realidad de la que ella es posibilidad.

El tránsito de la posibilidad real a la efectividad real es posible debido a que su relación tiene sólo un sentido lógico, y no un carácter temporal. Las nociones lógicas de posibilidad real y efectividad real no se refieren, pues, a la determinación temporal de la cosa, sino a la determinación pensada de la misma. ${ }^{180}$ Aunque parece que se ha partido de la posibilidad real para luego hacerla coincidir con la efectividad real, lo cierto es que, como hemos visto, Hegel parte de lo realmente efectivo, pues su sistema intenta pensar "lo que es", y no elucubrar mundos posibles. La posibilidad real, al igual que la formal, sólo aparece después de intentar pensar lo efectivo, mas no al revés. O mejor dicho, la posibilidad únicamente se presenta en el esfuerzo por aprehender lo realmente efectivo.

En sentido lógico decimos, y es lo que hace Hegel, que cuando se realizan ciertas condiciones (posibilidad real), entonces se presentan como cosa (efectividad real). Mientras que si atendiéramos al orden real (o temporal), algo que nos ayuda a mirar retrospectivamente el orden lógico, tendríamos que decir que sólo cuando se presenta una cosa en la existencia, es entonces que se pueden considerar las condiciones que la constituyen como ya estando realizadas, o de lo contrario la cosa no se habría presentado en la existencia (las condiciones específicas que conforman una cierta cosa sólo se pueden conocer cuando ésta ya está realizada). Una vez que la cosa es real, se puede

${ }^{180}$ La posibilidad, aunque real, no se trata de la posibilidad de una existencia en el tiempo, sino de la posibilidad de la existencia como existencia pensada. En este sentido, no se debe confundir la "posibilidad real" de una cosa con la "probabilidad" de la misma, pues mientras aquélla pertenece al orden lógico, ésta se refiere a la posibilidad de la cosa en el tiempo. Entendida de este modo la noción de posibilidad real transforma la manera tradicional de considerar a la posibilidad en general, pues muestra el fundamento racional de la existencia de una cosa sin referirse a su mera posibilidad o a su mera efectividad, sino a ambas. 
mostrar el conjunto de condiciones que hizo que deviniera real. En tanto son sus propias condiciones las que constituyen la posibilidad real de la cosa, la ausencia de ésta sólo demuestra que no se ha realizado su posibilidad real (no se han cumplido sus condiciones constitutivas). La ausencia de la cosa revela entonces la ausencia de su posibilidad real y muestra, a su vez, la necesidad de su realización para que la cosa se presente como algo realmente efectivo. De ahí que Hegel diga que, en su propia negación, la posibilidad real muestra la "identidad consigo".

Pero, si es posible establecer el tránsito del conjunto de condiciones concretas (posibilidad real) a la existencia concreta (efectividad real) de una cosa, entonces no se está sino haciendo explícita la necesidad real de la misma. En el momento en el que se reúnen todas las condiciones para la existencia de una cosa, no puede existir otra cosa sino ella misma, por lo que dicha cosa existe necesariamente. Mientras que pensar algo como formalmente posible puede conducir a otra cosa igualmente posible, determinar algo como realmente posible no puede conducir sino a ese mismo algo. Ahí reside el tránsito de la posibilidad real a la necesidad: $<<$ Lo que es necesario no puede ser de otra manera; sí, en cambio, lo posible en general, porque la posibilidad es el ser en sí que es sólo ser-puesto, siendo por consiguiente, esencialmente, ser-otro. La posibilidad formal es esta identidad, entendida como un pasar a lo sencillamente otro; pero la posibilidad real, por tener en ello el otro momento, la realidad efectiva, es ya ella misma la necesidad $>>.181$

La unidad de la posibilidad real y la efectividad real se muestra entonces como lo realmente necesario. Incluso se puede decir que la posibilidad real, en su realización efectiva, no es sino la necesidad real misma. En este caso, aquello que es pensado como realmente posible es, al mismo tiempo, pensado como realmente necesario: <<La negación de la posibilidad real es, por ende, su identidad consigo; en cuanto que ella, dentro de su asumir, es el contrachoque

\footnotetext{
${ }^{181}$ Ibíd., p. 613.
} 
[Gegenstoss] de este asumir dentro de sí misma, ella es la necesidad real>>.182 Cuando se realiza la posibilidad real de una cosa (esto es, cuando se torna efectividad real), ella pasa necesariamente a la existencia, por lo que su posibilidad real misma queda subsumida y se convierte en necesidad real.

De ahí que cuando se determina la posibilidad real de una cosa, en tanto no se refiere sino a la totalidad de condiciones que la constituyen como tal, se puede determinar su necesidad real: $<<$ Por consiguiente, realmente posible es aquello que no puede ser de otra manera; bajo estas condiciones y circunstancias, no puede seguirse otra cosa>>.183 Como se ha dicho, cuando todas las condiciones de una cosa están dadas, entra entonces por necesidad a la existencia. Con el tránsito, a partir de determinadas condiciones, hacia la efectividad de la cosa, el pensamiento llega a la necesidad real de la misma. En efecto, si se puede transitar de las condiciones reales a la presencia real de la cosa, entonces ésta existe necesariamente.

Una cosa es considerada como necesaria cuando no sabría ser de otro modo del que efectivamente es. Y si una cosa no es sino precisamente por el conjunto de condiciones que la constituyen, entonces ¿de qué manera podría negarse la necesidad de su existencia, cuando todas aquellas condiciones que la hacen ser se presentan en la existencia? Si se cumplen las condiciones necesarias para la existencia de una cierta cosa, ¿qué otra cosa cabría esperar que no sea la existencia misma de esa cosa? (una vez más, 'cosa' que sólo es en virtud de las condiciones que la determinan, pues sin determinación alguna, ninguna existencia se le podría predicar).

En el momento en el que se da la unidad entre la cosa y sus condiciones, entre lo condicionado (fundamentado) y lo condicionante (fundamento), la

\footnotetext{
${ }^{182}$ Loc. cit.

${ }^{183}$ Loc. cit.
} 
reflexión alcanza la modalidad de necesidad real. ${ }^{184}$ La única condición para que una cosa devenga realmente necesaria es el haber sido realmente posible. En cuanto se determina la posibilidad real de una cosa, ésta deviene necesaria en la existencia. Se puede decir que aquello que es realmente posible es simultáneamente realmente necesario. $\mathrm{O}$ bien, se puede decir que cuando una cosa es pensada como realmente necesaria, entonces se puede determinar la realización de ciertas condiciones en una unidad, que constituye la posibilidad real de dicha cosa. Todo lo realmente necesario es de antemano realmente posible, por lo que si una cosa es efectivamente necesaria, entonces la reflexión debe poder pensar retrospectivamente su posibilidad real como condición para su propia necesidad.

Si una cosa es realmente necesaria es porque ya ha sido realmente posible, y si es realmente posible es porque ya ha devenido realmente necesaria: $<<$ Por consiguiente, posibilidad real y necesidad están diferenciadas sólo aparentemente; ésta es una identidad que, en vez de ser algo que venga primeramente a ser [que le venga primero al ser], está ya presupuesta y situada de fundamento >>.185 De esta manera, la posibilidad real, como el todo de condiciones constituyentes de la cosa, y la necesidad real, como la cosa constituida por el todo de sus condiciones, son diferentes pues sólo en apariencia.

La cosa se presenta a la reflexión "siempre ya ahî" para que sus condiciones sean pensadas como su propia multiplicidad y, a su vez, las condiciones se presentan "siempre ya ahí" para que la cosa sea pensada como su propia unidad. ${ }^{186}$ En este sentido, el pensamiento puede reflexionar sobre la

${ }^{184}$ La cosa encuentra, pues, su fundamento en sus condiciones de existencia, y no en sí misma. En tanto este conjunto de condiciones constituye precisamente el fundamento de la cosa, cuando se presenta dicho conjunto, la cosa pasa de ser posible o contingente a ser necesaria (justo porque tiene ya un fundamento para ser).

${ }^{185}$ Loc. cit.

${ }^{186} \mathrm{La}$ cosa se encuentra ya siempre presupuesta en las condiciones determinantes que la fundamentan, y no es algo idéntico a sí mismo que venga a ser después independientemente de sus determinaciones. Del 
posibilidad en general de una cosa (pues ésta es ya siempre un objeto para el pensamiento), pero para reflexionar sobre su posibilidad real así como sobre su necesidad real, la cosa tiene que ser pensada como efectivamente real.

El pensamiento no actúa por sí mismo, ya que si se encuentra en la figura de lo real es porque de hecho tiene frente a sí algo realmente efectivo. Únicamente en tanto determinada cosa es realmente efectiva, el pensamiento puede establecer una relación de dicha cosa con sus condiciones concretas de existencia y, así, puede establecer tanto su posibilidad real como su necesidad real. Mientras un pensamiento abstracto se contenta con pensar que todo es posible, la figura real establece un dominio de lo realmente posible a través del cual, mediante la unidad de ciertas condiciones, puede determinar la necesidad real de una cosa.

La necesidad real concibe la unidad de la cosa pensada no como un dato, sino como un producto que, sin embargo, se encuentra ya presupuesto en sus condiciones mismas de existencia; mientras que la posibilidad real concibe la multiplicidad de propiedades como algo ya presupuesto en la unidad de la cosa existente. El pensamiento concibe a la cosa como realmente necesaria al comprenderla como la realización real de sus propias condiciones reales de existencia, es decir, como la efectividad de su posibilidad. Hay en la necesidad real, por tanto, una unidad entre lo efectivo y lo posible.

Se puede observar entonces que tanto en la figura formal como en la figura real, la identidad entre lo posible y lo efectivo deriva en la modalidad de lo necesario. ${ }^{187}$ Sin embargo, existe una diferencia. En el momento formal la reflexión parte de algo inmediatamente dado, para no volver sino a lo puramente inmediato, a lo que por cierto declara en última instancia como

mismo modo, las condiciones se hallan ya siempre presupuestas en la unidad de la cosa que fundamentan, y no son algo que tenga consistencia fuera de su unidad como elementos determinantes.

187 Recordemos que la unidad entre la posibilidad formal y la efectividad formal conducían a la necesidad formal; mientras que la identidad entre la posibilidad real y la efectividad real conducen a la necesidad real (pues la unidad de la cosa con sus condiciones de existencia hacen de ella algo realmente necesario). 
necesario. No obstante, esta necesidad formal permanece en el terreno de lo contingente, ya que las determinaciones que constituyen a lo inmediato como tal, aun en su mayor unidad, permanecen externas entre sí. En el momento real, en cambio, la reflexión parte de un algo ya mediado por la reflexión, de una existencia constituida por un conjunto de condiciones determinantes, para no regresar sino a esa misma existencia ahora plenamente mediada por la reflexión, mediada por sus propias condiciones constitutivas. ${ }^{188}$

A diferencia del momento formal, para el que la mera existencia de la cosa la convertía ya de por sí en algo necesario, permaneciendo con ello en la contingencia; el momento real alcanza a pensar la necesidad real de la cosa más allá de su pura existencia (sin embargo, como veremos a continuación, ello no la aparta del todo de la contingencia). En el momento real, la cosa no es considerada como necesaria únicamente por el hecho de existir, sino en virtud de su constitución como unidad de determinadas condiciones que la han hecho devenir lo que es. La necesidad real de la cosa viene dada por la descomposición y recomposición de la misma efectuada por un mismo movimiento reflexivo.

La modalidad de necesidad real no hace más que hacer explícito el conjunto entero de condiciones (posibilidad real) que dan presencia efectiva a la cosa pensada (efectividad real), la cual condensa en su unidad aquel conjunto condicionante de determinaciones. ${ }^{189}$ La necesidad real no es sino la explicitación de la posibilidad real de una cosa desplegándose en la efectividad real; y al hacerlo no muestra sino su necesidad, por lo que aquello que anteriormente se pensaba como posible o contingente, se piensa ya como necesario. El pensamiento concibe ahora lo efectivamente reflexionado como aquella parte de la realidad que comporta una necesidad intrínseca, esto es,

\footnotetext{
${ }^{188}$ En este sentido, el momento real se muestra superior al formal, ya que alcanza una determinación más concreta de lo efectivo.

${ }^{189}$ Como ya se ha dicho, posibilidad real y necesidad real van juntas. Determinar las condiciones de lo realmente posible es a la vez determinarlo como realmente necesario. Toda cosa se encuentra determinada por una totalidad de condiciones que la constituyen como tal, y en tanto no es sino este todo de relaciones el que la constituye como cosa, ésta encuentra su verdadero fundamento en esa totalidad, en ese todo que siempre ha estado ahí constituyendo su necesidad.
} 
aquello cuya necesidad se ve vinculada a un conjunto de condiciones reales dadas.

Ciertamente la necesidad real ha alcanzado una unidad reflexiva entre la cosa efectiva y sus condiciones de existencia, pero en tanto dicha cosa sólo deviene necesaria en la medida en que se cumplan tales condiciones, la necesidad real mantiene todavía un carácter contingente (la realización de la cosa depende de que se realicen sus condiciones de existencia, y no otras, lo cual resulta contingente). ${ }^{190} \mathrm{Y}$ al no excluir del todo la contingencia de su dominio, la necesidad real se convierte en necesidad relativa: $<<$ Esta necesidad es empero, al mismo tiempo, relativa. - Tiene en efecto una presuposición inicial, tiene en lo contingente su punto de partida. A saber, lo realmente efectivo real, en cuanto tal, es lo realmente efectivo determinado, y tiene por lo pronto su determinidad como ser inmediato en el hecho de ser una multiforme variedad de circunstancias existentes $>>.191$

Si bien, la necesidad real unifica la serie completa de condiciones constitutivas en la cosa pensada y alcanza con ello una cosa plenamente determinada, esta necesidad es relativa, pues aún considera a la multiplicidad de condiciones que constituyen la cosa como un dato que se le ofrece de inmediato. Es esta inmediatez de las condiciones, es decir, el que aparezcan como algo dado, lo que convierte a la cosa pensada en relativamente necesaria; pues dicha cosa depende de que se realicen, lo cual puede no ocurrir, sus condiciones de existencia (la cosa deviene necesaria si y sólo si se realizan sus condiciones constitutivas, pero en tanto la realización de las mismas puede no darse, entonces la presencia de la cosa se basa en la contingencia de sus condiciones, por lo que resulta sólo relativamente necesaria).

\footnotetext{
${ }^{190}$ En realidad la reflexión aún no ha dejado de concebir a la cosa y a sus condiciones como realidades independientes, cuyo encuentro resulta todavía contingente.

${ }^{191}$ Loc. cit.
} 
Es de este modo que la necesidad real tiene "una presuposición inicial", a saber, el que tales condiciones se realicen efectivamente, y en tanto depende de esta realización, la necesidad de la cosa es relativa. El que una cosa se manifieste en la existencia, depende de que se realice el conjunto entero de condiciones que la constituyen; pero si no se cumplen todas y cada una de sus condiciones, la cosa no puede devenir real y nada garantiza que se realicen ciertas condiciones y no otras, por lo que su misma realización es contingente. El que ciertas condiciones estén dadas, y no otras, responde a su carácter azaroso (contingente), y todavía no cuentan con un fundamento que les torne necesarias. La necesidad de la cosa depende de algo externo a ella: las condiciones. En tanto éstas se presentan como dadas, sin más fundamento, son contingentes; y ello convierte de inmediato a la cosa que constituyen en algo sólo relativamente necesario. La necesidad real de la cosa es una necesidad dependiente, depende de otro, esto es, de que se den o se realicen las condiciones que constituyen la cosa real.

En otras palabras, el pensamiento ha de mostrar que la necesidad real de la cosa no se halla en su pura inmediatez, sino en su propio movimiento reflexivo que atraviesa plenamente la cosa pensada. Este movimiento consiste en un proceso en el que la cosa es disuelta en sus condiciones constitutivas (posibilidad real), y las condiciones son traídas de regreso a la cosa para identificarse con ella en su unidad (efectividad real). En la necesidad real, la posibilidad (condiciones) y la efectividad (cosa) reales se identifican, pero en tanto constituyen momentos diferentes de la reflexión, no se presentan sino como algo separado; por lo que la necesidad real guarda todavía un carácter contingente: $<<$ [... La necesidad] se inicia de este modo a partir de aquella unidad de posible y realmente efectivo, todavía no reflexionada dentro de sí: este presuponer y el movimiento que retorna a sí están todavía separados; o 
sea, la necesidad no se ha determinado todavía, desde sí misma, hasta la contingencia $>>.192$

Como se ha notado con anterioridad, la necesidad real alcanza sin duda una cierta unidad entre la cosa y la multiplicidad de sus condiciones, pero deja subsistir a la vez una relativa escisión entre ambas, a las que sigue tomando como simples datos brutos independientes entre sí y que le habrían sido ofrecidos a la reflexión desde el exterior. ${ }^{193}$ En este sentido, la cosa y sus condiciones mantienen entre sí también una relación de exterioridad (por lo que las condiciones se muestran como externas a la cosa misma, y la cosa, que no es sino por sus condiciones determinantes, se muestra como algo todavía determinable independientemente de las mismas). La cosa y sus condiciones se presentan entonces como dos órdenes diferenciados, cuyo encuentro resulta fortuito.

Hay aquí, por tanto, una escisión entre dos polos todavía irreconciliables; polos que si bien carecen de determinación el uno sin el otro, aún no logran realmente su plena unidad. Es a causa de esta escisión entre la cosa y sus condiciones que la reflexión piensa todavía estar sujeta a algo dado externamente y mantiene, con ello, un cierto carácter contingente dentro de la necesidad real: <<Lo realmente necesario es por ello una cierta realidad efectiva limitada que, en virtud de este carácter limitado, es también —en otro respecto- solamente un ser contingente>>.194

Con base en esta contingencia, que se funda en la aparente exterioridad de lo efectivo, se podría decir que en la necesidad real no solamente las condiciones aparecen como contingentes, sino también la cosa misma (entendida como la unidad de tales condiciones), pues para poder ser pensada como realmente necesaria, la cosa debe ser considerada como algo dado...

\footnotetext{
192 Ibíd., p. 614.

${ }^{193}$ Con el fin de salir del mero formalismo, la reflexión se había comprometido con lo efectivo, pero en este momento real lo toma inadvertidamente como un simple dato.

${ }^{194}$ Loc. cit.
} 
puesto ahí para ser pensado. No obstante, a pesar de que su presuposición pueda hacer pasar a la cosa pensada como algo contingente, lo cierto es que sólo sus condiciones son contingentes. Mientras que la cosa pensada, en tanto se funda en la realización de sus condiciones, es necesaria; las condiciones, en tanto no cuentan con un fundamento que conduzca necesariamente a su realización, están sujetas a la contingencia. ${ }^{195}$

De este modo, al igual que la necesidad formal, la necesidad real no logra escapar del todo a la contingencia. El momento formal no pudo superar lo contingente debido a que partió de algo dado, y lo mismo le ocurre al momento real. Aunque la reflexión parte de una cosa determinada por el conjunto de sus condiciones, en tanto no deja de considerar a tales condiciones como un algo dado ahí en la existencia, parte en realidad de algo dado; por lo que la reflexión se encuentra todavía sujeta a la exterioridad de su contenido. El momento real parece haber alcanzado una síntesis entera en la cosa al mostrar su necesidad real, pero lo cierto es que, al permanecer en la contingencia no deja de ser más que una necesidad puramente relativa.

Es precisamente este carácter relativo de la necesidad real el que exige la superación misma del momento real; esta superación se ha de dar a través de una síntesis más acabada que al mismo tiempo contenga el momento anterior. El pensamiento especulativo no se conforma con una unidad relativamente necesaria y busca una síntesis más alta, una necesidad absoluta. Con ella espera alcanzar una síntesis aún más elevada que la hallada ya por la necesidad real, busca hallar la plena unidad entre la cosa y sus condiciones. No obstante, ¿puede el pensamiento levantarse por encima de esta necesidad relativa y mostrar una necesidad incondicionada tal como el propio

\footnotetext{
${ }^{195}$ De acuerdo con Hegel, la contingencia cae del lado del contenido, en tanto aparece como infundado, y no ya en la forma, que es ahora necesaria: $<<$ De hecho, la necesidad real es en sí [...] también contingencia. - Al pronto, ello aparece así: a saber, que lo realmente necesario, según la forma, sea ciertamente un necesario pero, según el contenido, limitado, y que tenga su contingencia en virtud de este contenido〉>. Ibíd., p. 614 .
} 
pensamiento se exige a sí mismo? A responder esta interrogante se dedicará el momento absoluto de las modalidades.

\section{Momento absoluto}

En el momento real, la reflexión ha partido de la multiplicidad de condiciones constitutivas de una cosa como algo dado, para sostener que la cosa deviene realmente necesaria en el momento en el que se realizan dichas condiciones. Pero en tanto tales condiciones aparecen como meros presupuestos que escapan a una fundamentación por parte de la reflexión, entonces la necesidad de la cosa es puramente relativa. Para que esta necesidad deje su carácter relativo y pueda ser plenamente fundamentada, la reflexión debe dejar de considerar a las condiciones constitutivas de la cosa como simples presuposiciones. De modo que si en la necesidad real el pensamiento logra una síntesis en la cosa a partir de una multiplicidad de condiciones dadas, en la necesidad absoluta buscará mostrar que esta multiplicidad que parece enfrentársele, no es sino el resultado de su propia actividad reflexiva. En el momento en el que el pensamiento deja de considerar a la cosa por un lado y a la multiplicidad de sus condiciones por otro, deja la necesidad relativa y se sitúa en el campo de la necesidad absoluta.

En la necesidad real, la realidad efectiva dependía de que se realizaran ciertas condiciones, dependía de que se presentaran sus condiciones constitutivas, esto es, se hallaba sujeta a su posibilidad real (una cosa devenía efectiva sólo si se presentaban sus condiciones de existencia). Aunque la necesidad real alcanza ya sin duda una unidad entre la cosa y sus condiciones, (entre la efectividad y la posibilidad) mantiene, sin embargo, la presuposición de la existencia inmediata. Esta presuposición no hace sino evidenciar la dependencia del pensamiento con respecto a lo exterior, esto es, frente a lo que le es ofrecido: <<este devenir, al ser exterioridad, es él mismo sólo el ser en sí 
de la necesidad real misma, por ser tan sólo un inmediato serdeterminado $>.196$ Pero el suponer como algo dado la multiplicidad de condiciones que constituyen la cosa pensada para ulteriormente pensar su unificación en dicha cosa, hace de la necesidad real algo relativo, pues la unidad entre la cosa y sus condiciones es puramente contingente: $<<$ Así, la necesidad real no sólo contiene en sí [an sich] la contingencia; sino que ésta viene a darse también en ella>>.197

En la necesidad absoluta, en cambio, la realidad efectiva ya no depende de sus condiciones, sino de sí misma. Es la misma efectividad la que se muestra como sus propias condiciones de existencia, como la explicitación de sus propias condiciones de posibilidad real. En otras palabras, se podría decir que en la necesidad absoluta las condiciones de la realidad efectiva ya han estado siempre realizadas. En cuanto las condiciones ya están realizadas constituyendo la realidad efectiva tal como es, ellas mismas son necesarias (y no posibles o contingentes), pues no son sino la efectividad misma que constituyen: $<<$ Esta realidad efectiva que es a su vez, en cuanto tal, necesaria al contener, en efecto, la necesidad como su ser en sí, es realidad efectiva absoluta: realidad efectiva que no puede ser ya de otra manera, pues su ser en sí no es la posibilidad, sino la necesidad misma>>. 198

A diferencia de la efectividad real, la efectividad absoluta no se funda en la posibilidad real (condiciones de existencia), sino en la propia necesidad (es decir, en lo que ya ha devenido como realidad efectiva, en la posibilidad real ya realizada). La realidad efectiva absoluta no depende ya de que se cumpla una cierta multiplicidad de condiciones para devenir lo que es, pues es su presencia misma como efectividad absoluta lo único que puede mostrar sus propias condiciones de existencia. En este sentido, tales condiciones pierden su carácter aparentemente externo a la cosa. Efectivamente, la necesidad absoluta, a

\footnotetext{
${ }^{196}$ Ibid., p. 615.

197 Ibíd., p. 615.

${ }^{198}$ Ibíd., p. 615.
} 
diferencia de la necesidad relativa, muestra que el carácter externo o dado de las condiciones (esto es, aquello que las hacía contingentes) es tan sólo una apariencia, y muestra que en realidad son un producto de la propia reflexión al tratar de pensar la realidad efectiva.

De hecho, la realidad efectiva es el punto de partida, y sólo retrospectivamente se puede observar qué condiciones cumplió para devenir lo que es en tanto efectiva. En efecto, cuando se piensa en la presencia absolutamente necesaria de una cosa, es porque sus condiciones se hallan ya de hecho cumplidas, y sólo retrospectivamente se puede pensar en dichas condiciones como algo que se ha tenido que cumplir para que la cosa deviniera precisamente como cosa (dicho de otra manera, una vez que lo efectivo ha devenido lo que es, entonces se pueden pensar las condiciones necesarias que dieron lugar a su existencia). En este sentido, en cuanto la realización de las condiciones sólo puede ser observada de manera retrospectiva, se puede decir que es la misma efectividad absoluta la que pone sus propias condiciones de existencia para devenir lo que es. ${ }^{199}$ Es la propia realidad efectiva absoluta la que, en tanto realizada, ha puesto su propia posibilidad real.

En el momento real, las condiciones fungían como un punto de partida de cuya realización devenía la presencia efectiva de la cosa; mientras que desde el momento absoluto, las condiciones fungen como un punto final cuya determinación sólo puede venir dada después de la presencia efectiva de la cosa. En otros términos, es la presencia de lo efectivo lo que permite especificar el conjunto de condiciones que se han realizado ya para dar paso a pensar eso mismo efectivo. Es lo efectivo lo que hace ver enteramente sus condiciones constitutivas, y no al revés (o por lo menos no del todo). Una vez que lo real está consumado, entonces se puede comenzar a determinar las condiciones que lo explican.

\footnotetext{
${ }^{199}$ En tanto la efectividad absoluta, como habiendo devenido lo que ya es, pone ella misma sus propias condiciones de posibilidad como ya realizadas, se puede decir entonces que dichas condiciones sólo pueden ser determinadas enteramente de modo retrospectivo.
} 
Así, como se ha dicho, una efectividad absoluta no depende de la realización de sus condiciones, pues es ella misma la que, en tanto realizada, pone sus propias condiciones de posibilidad (ella no es sino estas mismas condiciones ya realizadas), por lo que tal posibilidad ya no es sólo real, sino absoluta. La posibilidad es absoluta en tanto no hace referencia sino a las condiciones constitutivas de lo efectivo como algo ya realizado. Esta posibilidad absoluta, a diferencia de la posibilidad real, se muestra como algo que siempre ya ha estado realizado, constituyendo la cosa pensada como algo efectivo.

La posibilidad absoluta no se refiere a la realización de una cierta multiplicidad de condiciones para hacer devenir una cosa, sino se refiere al hecho de que al poder de pensar una cosa es porque sus condiciones ya están realizadas, por lo que se puede decir que es al devenir como cosa que ella ha puesto ya tales condiciones. En tanto la cosa ha puesto sus mismas condiciones de posibilidad, no depende más que de sí para ser, por lo que es necesaria independientemente del contenido de dichas condiciones. En este sentido, la cosa es indiferente al contenido de las condiciones que ella misma ha puesto, pues dicho contenido no determina su presencia efectiva. La cosa pone el contenido de sus propias condiciones, pero en tanto su efectividad no depende de tal contenido, es indiferente ante el mismo. Una cosa efectiva no depende del contenido de sus condiciones propias para devenir efectiva. Más allá del contenido de las condiciones que conforman lo efectivo, son las condiciones mismas de posibilidad que se impone a sí mismo lo efectivo lo que se muestra como realizado en su presencia efectiva que, por tal motivo, se queda en la vacuidad. Se presenta como vacío en tanto es indiferente a su contenido:

[...] Esta realidad efectiva, por estar puesta como absoluta, es decir, por ser ella misma la unidad de ella y de la posibilidad, es solamente una determinación vacía; o sea, es contingencia. - Esta vacuidad de su determinación hace de ella una mera posibilidad, una cosa que precisamente en la misma medida puede ser también de otra manera, y 
venir determinada como posible. Pero esta posibilidad es, ella misma, la posibilidad absoluta, pues es justamente la posibilidad de venir determinada lo mismo como posibilidad que, en la misma medida, como realidad efectiva. Con esto, a saber, el hecho de que ella es esta indiferencia respecto a sí misma, está puesta como determinación vacía, contingente. ${ }^{200}$

A pesar de que se asoma ya aquí la contingencia, por el momento se puede decir que, la realidad efectiva es absolutamente necesaria si la reflexión puede determinar el conjunto específico de condiciones que han tenido que realizarse para que justo haya tenido que devenir dicha realidad efectiva, y no otra. Al determinar este conjunto de condiciones, la reflexión puede dar cuenta de la razón de ser de la realidad efectiva y, por tanto, de su necesidad. La realidad ha devenido lo que es porque ya es lo que es. Para que algo sea real, tiene que haber devenido como tal, es decir, toda realidad se trata del resultado de un proceso, y no de algo dado. Pero el que la realidad efectiva devenga justo ella responde a un proceso enteramente inmanente al mismo movimiento de dicha realidad. Es su propio proceso el que hace que la realidad devenga ella misma, y no otra; es su proceso el que determina que devenga lo que es, y no algo que no es.

Una vez en su proceso, no hay manera de que la realidad devenga de otro modo, es necesariamente como es, pues ella misma no es sino su propio proceso. En este sentido, el ser y su devenir coinciden, pues nada puede devenir otra cosa que lo que ya es como proceso, éste se identifica necesariamente con lo que deviene de él, pero todo esto una vez que ya ha devenido. No hay forma de adelantarse al tiempo propio y determinar lo que ha de ser necesario, pero una vez que un proceso ha devenido en cosa, entonces se puede determinar el proceso específico que ha hecho devenir a dicha cosa como tal. Sólo entonces se

\footnotetext{
${ }^{200}$ Ibíd., p. 615.
} 
puede explicar por qué una cosa es como es, y no de otra manera, esto es, se puede determinar su necesidad.

En tanto nos es imposible adelantarnos al tiempo propio, no contamos con un punto de vista externo (sub specie aeternitatis) que nos permita determinar aquello que ha de devenir necesariamente efectivo, por lo que la necesidad de las cosas únicamente puede ser determinada una vez que han ocurrido, una vez que lo efectivo ha devenido justo como ese efectivo a través de su proceso inmanente de constitución. ${ }^{201}$ De ahí que su necesidad venga dada por el hecho de no ser más que el resultado de su mismo proceso de autoconstitución, aquel proceso que le ha hecho devenir como tal. No obstante, si fuera posible adelantarse al tiempo presente y tener un punto de vista externo, se podría determinar aquello que ha de devenir efectivo, se tendría un punto de vista desde el cual se podría establecer que se haya de realizar necesariamente una cierta cosa en lugar de otra. Se podría determinar aquello que debería devenir de un cierto proceso y aquello que no debería devenir del mismo; se podría determinar que un cierto proceso deviniera en lugar de otro, que el proceso fuera de otro modo y que, por tanto, resultara en otra cosa.

Pero en tanto no contamos con una perspectiva desde la que podamos establecer el que se tenga que realizar necesariamente una cosa en vez de otra, da cabida a la contingencia. En efecto, la ausencia de un punto de vista externo al devenir mismo de lo efectivo que muestra su aspecto necesario, muestra, al mismo tiempo, su carácter contingente. En efecto, al no existir un punto de vista absoluto, no existe la posibilidad de determinar la necesidad de las cosas de antemano, y aquí es donde encuentra su lugar la contingencia. Todo se muestra contingente hasta que no muestra el proceso que lo ha hecho ser como es, y no de otro modo, esto es, el proceso que lo ha hecho ser absolutamente necesario.

${ }^{201}$ En tanto no existe un punto de vista externo, y sólo contamos con el punto de vista de una reflexión que emprende su actividad una vez que la realidad se ha consumado, lo real mismo ha tenido que devenir necesariamente lo que ya es. 
Como se ha ya anunciado, la efectividad absoluta, al poner sus propias condiciones de posibilidad, no sólo resulta necesaria, sino también contingente. En efecto, si la realidad, que pone las condiciones que le hacen ser como tal, hubiese sido otra realidad, habría puesto otras condiciones que las que ha puesto. Una realidad diferente necesariamente ha de poner condiciones diferentes, ya que de lo contrario no podría devenir ella misma, sino alguna otra. En este sentido, para Hegel la necesidad misma es $<<$ la que se determina como contingencia: en su ser se repele de sí; en esta misma repulsión, no ha hecho sino retornar a sí, y en este retorno —entendido como su ser- se ha repelido de sí misma>>.202 El que la propia necesidad se determine como contingente no significa que elimine la contingencia, sino que, por el contrario, la mantiene en toda su firmeza. Aquella realidad que se revela como absolutamente necesaria, muestra dentro de sí su propio carácter contingente.

En cuanto nada impide que la realidad efectiva se determine de una cierta manera, es contingente que sea como es; pero en tanto esta realidad efectiva se determina a sí misma de una cierta manera, y no de otra, es necesario que sea como es. La efectividad absoluta es lo que es porque ella misma ha devenido como tal, y en tanto ha devenido como es, y no como lo que no es, se torna necesaria. Ha devenido necesariamente como lo que ya es. En tanto la efectividad absoluta se autoconstituye a través de su mismo proceso, no depende sino de sí misma ${ }^{203}$, e incluso es lo que es sin importar su contenido. La realidad efectiva absoluta es lo que es con independencia de su propio contenido, por lo que es indiferente al mismo (cualquier cosa, sin importar qué o cómo sea, esto es, con independencia de su propio contenido, ha devenido lo que es por el proceso en el que se autoconstituyó). ${ }^{204}$ De acuerdo con Hegel,

${ }^{202}$ Loc. cit.

${ }^{203}$ Mientras que la efectividad real dependía de la realización de sus condiciones constitutivas (su posibilidad real); la efectividad absoluta, por el contrario, pone sus propias condiciones de existencia (su posibilidad absoluta), por lo que ya no depende de un otro, sino de sí misma. Al no depender de algo externo, es causa de sí.

${ }^{204}$ El que una cosa sea como es se debe a que ha devenido como tal, lo cual no implica que no hubiera podido ser de otro modo, pero en tal caso tendría que haber devenido precisamente de ese otro modo. 
$<<$ ella es la realidad efectiva; sin embargo, una tal que sólo se da como este simple coincidir de la forma consigo misma $>>205$, ya que no depende más de un contenido específico para ser lo que es, la forma se da su propio contenido:

Así, la forma, en su realización, ha penetrado todas las diferencias y se ha hecho transparente, y es, en cuanto necesidad absoluta, solamente esta simple identidad consigo misma del ser en su negación, o sea en la esencia.- La diferencia misma entre el contenido y la forma ha desparecido así, justamente; pues aquella unidad de la posibilidad en la realidad efectiva y viceversa es la forma indiferente, en su determinidad o en el ser-puesto, a sí misma: la Cosa plena de contenido, en la que la forma de la necesidad se dispersaba [y perdía] exteriormente. ${ }^{206}$

En el momento absoluto, la forma ya no depende de un contenido externo, le es indiferente cualquier contenido particular, pero no porque lo suprima, sino porque lo trae consigo. La forma subsume al propio contenido y lo pone como algo propio, por lo que este poner es un coincidir de la forma consigo misma. En este sentido, ya no se contraponen más, existe una unidad entre forma y contenido. Esta unidad no hace referencia sino a la identidad de la realidad efectiva en su propia realización.

Pero, la realidad efectiva, en tanto ha devenido como lo que es, no se muestra sino como resultado de su propio proceso de autoconstitución, por lo que, en su necesidad absoluta, se manifiesta como causa de sí ("es porque es"). La realidad efectiva, como necesidad absoluta, es $<<$ el ser que dentro de su negación, dentro de la esencia, se refiere a sí, y es ser. Ella es, precisamente en la misma medida, tanto inmediatez simple o ser puro, cuanto simple reflexióndentro-de-sí o esencia pura; ella es el hecho de que ambos sean una y la misma

\footnotetext{
205 Ibíd., p. 615.

${ }^{206}$ Ibíd., p. 616.
} 
cosa >>.207 La esencia de la realidad efectiva consiste en manifestarse en lo existente, en el haberse dado a la existencia; su esencia es su propia existencia

Hay aquí una unidad de ser y esencia donde lo realmente efectivo es porque es. ${ }^{208}$ En efecto, Hegel dice que, considerada como algo absolutamente necesario, la realidad efectiva <<es así porque es>>.209 Pero lo que hace necesaria a lo efectivo no es su propio ser, sino su devenir: "él es, por el hecho de que él es". De ahí que, no se trata esta vez de un ser puramente inmediato, sino de un ser absolutamente mediado por la reflexión que es puesto ahora como inmediato (se trata de una inmediación absolutamente mediada o de una mediación puesta como simple inmediatez): $<<$ La necesidad absoluta es así la reflexión o forma del absoluto; unidad de ser y esencia, inmediatez simple que es negatividad absoluta $>>.210$

La realidad efectiva absolutamente necesaria es ciertamente inmediatez, pero una inmediatez puesta como absoluta negatividad. La realidad efectiva es negatividad absoluta en tanto ella misma produce el proceso por el que se constituye. En este sentido, en tanto la realidad efectiva se autoconstituye, es causa de sí. Ciertamente todo aquello que se autoconstituye puede tener cualquier resultado, pero, en tanto es causa de sí, este resultado ha de ser necesario. De este modo, el proceso de autoconstitución es, a la vez, necesario y contingente. Necesario porque una cosa siempre deviene lo que ella misma es, no puede devenir lo que ella no es; contingente porque el que una cosa devenga tal o cual no se halla determinado a priori de modo absoluto. ${ }^{211}$

\footnotetext{
${ }^{207}$ Ibíd., p. 616.

$208<<$ Lo sencillamente necesario es, por el hecho de que él es; no tiene por lo demás ninguna condición ni fundamento. - Así es empero, justamente, esencia pura; su ser es la simple reflexión-dentro-de-sí; él es, por el hecho de que él es. Al ser reflexión, tiene fundamento y condición, pero sólo se tiene a sí por fundamento y condición. Es ser en sí, pero su ser en sí es su inmediatez, su posibilidad es su realidad efectiva. - Luego es, por el hecho de ser; al ser la coincidencia del ser consigo, es esencia; pero como esto simple es, de igual manera, simplicidad inmediata, es ser〉>. Ibíd., p. 617.

${ }^{209}$ G.W. F. Hegel, Enciclopedia de las ciencia filosóficas (Madrid: Alianza, 1999), p. 238.

${ }^{210}$ G. W. F. Hegel, Ciencia de la lógica (Madrid: Abada, 2011), p. 617.

${ }^{211}$ Nunca faltarán ciertas condiciones que incidan en el proceso de autoconstitución de una cosa, y son ellas las que definirán lo que la cosa ha de ser finalmente.
} 
Si las condiciones en las que se define una cosa son diferentes, es porque la cosa es ya diferente. Cuando la cosa aún no ha devenido real, dichas condiciones siempre podrían haber sido diferentes, esto es, son contingentes; pero cuando una cosa es ya real, ella misma muestra sus propias condiciones como algo necesario.

Es su negatividad absoluta, el proceso por el que se autoconstituye, lo que hace de la realidad efectiva algo necesario, pero a la vez algo contingente. Esta negatividad absoluta encierra, pues, tanto la necesidad como la contingencia, ya que un proceso puede resultar cualquier cosa, y por ello es contingente, pero sin importar del modo en que resulte, ha de hacerlo así forzosamente, y por ello es necesario. Como se ha dicho anteriormente, en tanto se carece de un punto de vista externo desde el que sea posible establecer el resultado de un proceso, éste se puede determinar libremente de otro modo. Pero por el mismo hecho de no contar con un tal punto de vista externo, no es posible que un proceso se determine libremente de otro modo, pues su resultado es porque es, es de cierto modo y no de otro.

La realidad efectiva absoluta no es algo inmediato, algo dado, sino que es el resultado de su negatividad absoluta, de un proceso por el que ella misma ha devenido como tal y se muestra como causa de sí. La realidad efectiva revela el conjunto de condiciones que en su unidad no pudieron sino devenir necesariamente en esa realidad efectiva, su unidad se muestra como no pudiendo haber devenido otra cosa.

No obstante, la realidad efectiva no puede ser reducida a su conjunto de condiciones constitutivas, ya que ella es su conjunto de condiciones más la trama de relaciones en la que entran entre sí tales condiciones, el proceso por el que han devenido una cierta realidad efectiva y no otra. La realidad efectiva absoluta no puede devenir otra diferente, no puede sino devenir ella misma, pero ella misma pudo devenir otra, y en tal caso también tendría que haber 
devenido necesariamente ella misma. Lo que da cuenta de la necesidad absoluta de una cierta realidad efectiva es el proceso que explica su razón de ser en la existencia, por lo que si se tratara de otra realidad efectiva, sería la explicitación del proceso que explicaría su presencia en la existencia lo que daría cuenta de su necesidad absoluta. Nada determina de antemano que se dé una cosa y no otra, pero una vez dada cierta cosa, ésta muestra su razón de ser al hacer explícito el proceso que le ha traído a la existencia.

De acuerdo con Hegel, si no se puede establecer de antemano aquello que ha de ser absolutamente necesario, $<<$ la necesidad absoluta es por consiguiente ciega $>>{ }^{212}$ En tanto la constitución de la realidad efectiva no sigue ningún orden preestablecido, en tanto no se trata sino de una autoconstitución, su necesidad es ciega. Pero el que la necesidad absoluta sea ciega no significa que la realidad responda a un destino, a un futuro inevitable, a un porvenir ineludible. La necesidad absoluta no busca sostener un ciego fatalismo. Por el contrario, en tanto ciega, la necesidad absoluta no alude a un rumbo predeterminado que tenga que obedecer la realidad efectiva para ser lo que es, ella deviene necesariamente lo que es en su libre proceso de autoconstitución.

Así, de acuerdo con nuestro autor, $<<$ la ciega transición de la necesidad es, más bien, la propia exhibición del absoluto, el movimiento dentro de sí del mismo, que, al exteriorizarse, se muestra más bien a sí mismo > ${ }^{213}$ La necesidad absoluta se refiere al mostrarse mismo del absoluto. Al exteriorizarse, el absoluto no se muestra como un otro de sí mismo, sino que es él mismo, se exhibe o expresa a sí mismo. Es en su propio movimiento interno que el absoluto se manifiesta externamente. Pero lo absoluto no se manifiesta bajo un contenido específico en particular, sino que su manifestación consiste en objetivarse a sí mismo como lo que es, es decir, en darse objetividad como proceso, que tiene en sí su propio movimiento. Una vez alcanzado el absoluto en

\footnotetext{
${ }^{212}$ Ibid., p. 617.

${ }^{213}$ Ibíd., p. 618.
} 
su propio despliegue necesario, extraigamos ahora algunas consecuencias que nos ha arrojado la modalidad de necesidad absoluta y que merecen ser retomadas en tanto mantienen una ruptura con respecto a la necesidad real con la que frecuentemente es interpretado el idealismo absoluto.

Hemos visto que en la necesidad absoluta, la cosa y sus condiciones no son ya datos brutos que se le ofrezcan ahí al pensamiento, sino resultados, entidades que no son sino por la mediación reflexiva. Tanto las cosas como sus condiciones son consideradas como resultado de la reflexión ${ }^{214}$, y no como presupuestos (pues incluso en el momento en el que aparecían como presupuestos eran ya de hecho un producto reflexivo, eran puestos por la misma reflexión). No se trata de datos originarios, ni puros, independientes del movimiento reflexivo. La necesidad absoluta revela que no existe como tal un dato puro, que aquello que aparece como un dato inmediato se encuentra ya mediado por la reflexión, se halla en medio de un conjunto de determinaciones reflexivas que le hacen ser como tal. La cosa y sus condiciones se presentan tan sólo como momentos, aunque ciertamente necesarios, de la reflexión que busca pensar lo efectivo, y al pensarle le transforma al mismo tiempo que le constituye como tal (como la unidad de la cosa con sus condiciones), por lo que no concibe lo efectivo sino como resultado de su propia actividad. Cuando el pensamiento intenta fundamentar la necesidad absoluta de la efectividad pensada, pone a la cosa y a sus condiciones como presupuestos, como momentos necesarios en su proceso reflexivo, pues en realidad no son sino resultados. Así, la necesidad absoluta echa por borda toda separación (ya sea de un más allá trascendente o de un más acá trascendental).

Aquello que en la necesidad real aparecía como escindido en entidades independientes, y cuya relación no se tornaba sino en algo contingente, en la necesidad absoluta desaparece como tal, como algo independiente. Aquella exterioridad, tanto de la cosa como de sus condiciones, que hacía de la

\footnotetext{
${ }^{214}$ Por supuesto en sentido epistemológico, y no ontológico, si es que aún cabe este término.
} 
necesidad real algo contingente ${ }^{215}$, es subsumida por la necesidad absoluta. En tanto la modalidad de necesidad absoluta busca una unidad incondicionada, deja de considerar a las condiciones constitutivas de una cosa como algo dado, como algo que después de ser unificado daría paso al surgimiento de la cosa (la necesidad absoluta deja de considerar lo efectivo como la unión de entidades independientes, como la unidad de la cosa con sus condiciones que, a pesar de su conjunción, permanecerían concebidas por separado; en el momento absoluto, esta separación es pensada tan sólo como una abstracción del pensamiento).

Tanto las condiciones como la cosa carecen de subsistencia propia, la una sólo lo es por la otra y adquieren sentido únicamente por el movimiento reflexivo que trata de pensar lo efectivo. Transformando enteramente aquello que se considera como dado y, con ello, no conteniendo ya ninguna presuposición, la necesidad absoluta se coloca como la verdad de la necesidad relativa. A diferencia de la necesidad real, en la necesidad absoluta no existe algo meramente dado. Todo lo que aparece como inmediato (ya sea la cosa o sus condiciones) es transformado dentro del pensamiento justo al momento que se le presenta. En la necesidad absoluta no existe algo más allá de la actividad reflexiva. Fuera de esta actividad reflexiva, ni la cosa ni sus condiciones poseen algún significado, carecen de toda determinación $\mathrm{y}$, en consecuencia, de existencia alguna. Esto no significa que no exista algo fuera del pensamiento que todavía no sea objeto de reflexión, pero ese algo carece de toda verdad fuera de las figuras del pensar. Toda cosa pensada adquiere verdad sólo a través de la actividad sintética del pensamiento en tanto es reconducida a su unidad pensada.

${ }^{215}$ Hemos visto que, en tanto no escapa a la contingencia de la existencia inmediata, la necesidad real es únicamente relativa. La relatividad de esta necesidad reside en que contiene el presupuesto de una existencia dada $\mathrm{y}$, por tanto, contingente, pues todavía no ha sometido a reflexión y dado un fundamento a la multiplicidad de condiciones que se le presentan para pensar la cosa. 
Por consiguiente, nunca hay algo meramente ahí dado, pues lo que se presenta de inmediato al pensamiento es desde ese momento pensamiento; no hay ninguna cosa dada, ningún residuo que escape a la actividad reflexiva del pensamiento. En este sentido lo absolutamente necesario representa una crítica de raíz a la idea kantiana de una “cosa en si” que permanece independiente al pensamiento. Pues bajo la modalidad de necesidad absoluta, una tal cosa en sí sería ya también un producto del pensamiento (sería una cosa que, al pretender permanecer libre de determinación, tendría la única determinación de estar indeterminada; sería una determinación indeterminada, pero al fin una determinación, es decir, un producto del pensamiento, aunque lo sea del pensamiento abstracto).

Efectivamente, Hegel ciertamente adopta el principio kantiano de que lo que es, sólo lo es en tanto ser pensado, pero lo lleva hasta sus últimas consecuencias, pues a diferencia de Kant, Hegel sostiene que, en tanto ser pensado, en tanto producto del pensamiento, la cosa puede ser conocida en sí misma. En la filosofía kantiana, aunque la cosa en sí resulta completamente pensable no resulta, sin embargo, cognoscible; por el contrario, en la filosofía hegeliana incluso esta cosa en sí, en la medida en que sólo existe como cosa pensada, es susceptible de conocimiento. El postulado de una cosa en sí, pensado en su plenitud, convierte a esta cosa misma en objeto de conocimiento. En su completa reconstitución reflexiva, el pensamiento sobre la cosa se identifica con la cosa como pensamiento. El pensamiento se torna en la esencia misma de la cosa, constituye el fundamento único de la cosa pensada. Y en el momento en el que la reflexión sustrae (o mejor dicho, subsume) toda inmediatez de la cosa pensada y la reconstituye como tal en sus determinaciones esenciales, el pensamiento puede definir su necesidad absoluta.

$\mathrm{Si}$ aquello que aparece de inmediato como cosa es completamente reconstituido por la actividad reflexiva, esto es, si logra ser constituido en su 
totalidad subsumiendo toda exterioridad, entonces es concebido por el pensamiento como algo absolutamente necesario. El que la necesidad absoluta subsuma toda exterioridad de la cosa pensada, no es porque la ignore como algo exterior, sino porque pretende constituirla como tal a través de sus determinaciones esenciales, con lo que esa exterioridad es puesta, constituida reflexivamente, por el pensamiento. La cosa no es ya mera exterioridad, sino el resultado de las determinaciones del pensamiento mismo. Empero, aquí cabe señalar que toda determinación del pensamiento no es sino el producto de una síntesis de su reflexión en su intento por pensar la cosa. La cosa no es más que la síntesis lograda por el movimiento reflexivo que unifica su contenido pensado en su forma pensada, es la unidad de forma y contenido. Y nada más.

Cuando la reflexión logra al fin pensar la unidad entre forma y contenido, logra pensar a la cosa en su absoluta efectividad, en su absoluta necesidad. En la necesidad absoluta, la cosa y las condiciones se hallan en una unidad indisoluble. ${ }^{216}$ En este sentido, el pensamiento reflexiona sobre la cosa al mismo tiempo que reflexiona sobre las condiciones; e inversamente, reflexiona sobre las condiciones al mismo tiempo que reflexiona sobre la cosa. De modo que la plena unidad de la cosa con sus condiciones se refiere a la cosa como condiciones o, mejor aún, a las condiciones como cosa. O en otros términos, se puede decir que la multiplicidad de condiciones constituye el fundamento de la cosa, y la cosa constituye, a su vez, el fundamento de las condiciones (en tal caso existe un ir y venir del fundamento a lo fundamentado).

Ante todo, la modalidad de necesidad absoluta constituye una ruptura inmediata con respecto a la modalidad de necesidad real, pues a diferencia de esta última, aquélla implica dejar de considerar la relación entre la cosa (lo efectivamente real) y sus condiciones (su posibilidad real de existencia) como

${ }^{216}$ De ahí que en la necesidad absoluta, las modalidades de posibilidad (las condiciones reales) y de efectividad (la cosa real), en tanto se hallan intrínsecamente unidas, apenas si encuentran un significado independiente entre sí. 
algo externo. La necesidad absoluta no supone ya una independencia, ni una exterioridad, entre dos realidades, entre la cosa (efectividad real) y sus condiciones de existencia (posibilidad real), sino que logra pensar su unidad íntegra; pero considerados en su independencia, como lo hace la necesidad real, más que necesarios se presentan como contingentes (tomados en su relación, dichos momentos se presentan como contingentes, y no como necesarios, pues lo único necesario sería su unidad).

Considerados desde un inicio como momentos separados, lo realmente posible y lo realmente efectivo, resultan finalmente inconmensurables, pues a pesar de que la necesidad real busque unificarlos, no logra hacerlo plenamente, sino sólo de modo relativo. De ahí que para hacer de lo realmente posible y lo realmente efectivo tan sólo momentos de una unidad indisociable es menester transitar de la necesidad real a la necesidad absoluta. A diferencia de la necesidad real, la necesidad absoluta logra subsumir la contingencia, por lo que aquello que permanecía como contingente es absorbido (o consumido) por lo absolutamente necesario que, a su vez, en tanto la contiene, se torna en condición de esa misma contingencia. En este sentido, la contingencia de la necesidad real es puesta por la necesidad absoluta misma. El momento de exterioridad de las condiciones no se revela sino como la manifestación de sí de la necesidad absoluta. Es la misma necesidad absoluta la que en cierto momento, en tanto real, se determina como siendo meramente contingente.

En este momento la necesidad es absoluta porque no deja sobrevivir nada externo a la cosa que pudiera llevarla a ser interpretada o considerada como contingente. La necesidad absoluta subsume, pues, la contingencia en la que había derivado la relación entre la posibilidad y la efectividad tanto en la necesidad formal como en la necesidad real. De ahí que la $<<$ la necesidad 
absoluta es, por tanto, la verdad a la que regresan realidad efectiva y la posibilidad en general, así como la necesidad formal y la real>>.217

Con la modalidad de necesidad absoluta el pensamiento cambia su posición ante la objetividad que pretende pensar, pues adopta una postura especulativa que los momentos anteriores de la reflexión no habían previsto. $\mathrm{Ni}$ el momento formal, ni el momento real alcanzaron a concebir y, tal vez, ni siquiera a sospechar, lo que el pensamiento especulativo logra pensar efectivamente. Desde los momentos anteriores, más abstractos, no se puede alcanzar una reflexión plena sobre la efectividad, sobre la efectividad absoluta. Cuando logra alcanzar su modo más alto de reflexión, la necesidad absoluta, el pensamiento muestra a lo absolutamente efectivo como la esencia o la verdad de todos sus momentos anteriores.

En la necesidad absoluta, el pensamiento muestra que aquella multiplicidad que parece oponérsele y que parece ofrecerse como algo ya dado ahí, carece en sí misma (si aún cabe usar esta expresión), de verdad alguna a no ser que sea atravesada por la reflexión. El pensamiento se muestra, así, crítico ante toda presuposición (tanto de la cosa como de sus condiciones). En tanto las condiciones que parecen ofrecérsele al pensamiento no son más que el resultado de su propio movimiento reflexivo, y en tanto dichas condiciones no son sino las determinaciones que constituyen a la cosa pensada como tal, entonces la cosa misma no es más que el producto de la actividad reflexiva del pensamiento. Existe entonces una plena unidad entre el pensar y lo pensado, entre el pensamiento y la cosa pensada.

En la necesidad absoluta se alcanza, pues, una completa identidad entre el ser y el pensar, el uno no tiene lugar sin el otro, son idénticos en su propia diferencia. Las cosas no son sino conforme al pensamiento, el cual no es sino conforme a las cosas (como cosas pensadas). La necesidad absoluta consiste en

\footnotetext{
${ }^{217}$ Ibíd., p. 616.
} 
un mismo y único proceso reflexivo en el que el pensamiento constituye enteramente a la cosa como tal y se constituye a sí mismo. La constitución de la cosa y la autoconstitución del pensamiento ocurren de modo simultáneo (en el mismo movimiento en el que el pensamiento critica lo efectivo, se critica a sí mismo, critica sus propios presupuestos).

En la necesidad absoluta el pensamiento alcanza el saber de sí, pues reconoce la necesidad en la que se funda: el pensamiento sabe que al reflexionar sobre la esencia y la existencia de lo pensado (el fundamento y lo fundamentado), no reflexiona sino sobre sí mismo, sobre su propia actividad de unificación. En efecto, en la figura absoluta, el pensamiento que reflexiona sobre la cosa lo hace, a la vez, sobre sí mismo; ya que dicha cosa sólo es por la reflexión misma. No obstante, esto no significa que el pensamiento cree las cosas a partir de sus propias fuerzas, sino que las configura como objetos del pensamiento. En su movimiento reflexivo, el pensamiento no deja intacto lo inmediato que se le ofrece, sino que lo atraviesa categorialmente, y al atravesarlo lo transforma sustancialmente en eso mismo inmediato.

En el último momento de las modalidades, la necesidad es absoluta porque en ella la cosa es plenamente reconstituida en las determinaciones que la definen como tal, como absolutamente necesaria. Una cosa sólo es absolutamente necesaria como cosa mediada, y no en su inmediatez; es la mediación del pensamiento la que le otorga su identidad a las cosas: $<<\mathrm{La}$ necesidad absoluta es relación absoluta porque ella no es el ser en cuanto tal, sino el ser que es por el hecho de ser, el ser en cuanto mediación absoluta de sí consigo mismo >>.218 De este modo, la necesidad absoluta no es algo que sólo se dé en el pensamiento y que sea extraño a la cosa. Pues esta necesidad absoluta no es algo que surja de un pensamiento que trabaje por sí mismo, sino surge del esfuerzo mismo por pensar un algo.

\footnotetext{
${ }^{218}$ Ibíd., p. 620.
} 
Así, cuando el pensamiento logra pensar la cosa bajo la modalidad de necesidad absoluta, la constituye al mismo tiempo como absolutamente necesaria; ya que fuera de las determinaciones del pensamiento, la cosa no encuentra determinación por ningún lado y, en consecuencia, también carece de verdad alguna.

Con esto se establece una relación entre la necesidad absoluta y la verdad, pues ambas son producidas por el mismo movimiento del pensamiento que intenta dar síntesis a lo pensado, lo verdadero (o lo absolutamente necesario) se alcanza cuando se logra una identificación de la cosa consigo misma en el pensamiento. Al final es la actividad del pensamiento la única que puede producir la verdad de las cosas. Es únicamente en la forma ${ }^{219}$ del pensamiento que tiene lugar la verdad de la cosa. Efectivamente, para que una cosa sea tal, es menester que sea reconstituida mediante las determinaciones reflexivas del pensamiento, ya que fuera de tal mediación no hay más nada, ningún sustrato que pudiera guardar algún sentido. Más allá de la determinación del pensamiento, la cosa — suponiendo que todavía se pueda hablar de tal— no oculta ningún sentido a descubrir, ningún mensaje a descifrar. Para que una cosa pueda ser objeto de experiencia requiere ser mediada por las determinaciones del pensamiento.

La reflexión realizada sobre la cosa es, a la vez, el movimiento del pensamiento que la constituye justo como objeto de reflexión. Es a la actividad reflexiva a la que debe su existencia misma (el ser no es sino como pensamiento). Al reflexionar sobre una cosa (Sache), el pensamiento no pasa por encima de ella para aprehenderla, sino que la atraviesa completamente para constituirla como tal, para constituirla como objeto (Gegenstand) del pensamiento. En este sentido, lo absolutamente necesario no es la cosa, sino el proceso reflexivo del pensamiento que la constituye como tal, como algo

\footnotetext{
${ }^{219}$ Forma que se va dando en su esfuerzo por pensar a la cosa, o mejor dicho, por constituirla como pensada.
} 
necesario en sentido absoluto, de ahí que $<<$ la necesidad absoluta no es tanto lo necesario, y menos aún un [ser] necesario, cuanto necesidad: ser sin más como reflexión>>. ${ }^{220}$ Se trata de un proceso reflexivo que subsume todo presupuesto $y$, por ende, toda contingencia.

Para arribar a esta necesidad absoluta, el pensamiento ha tenido que transitar una serie de momentos en su reflexión hecha sobre la realidad efectiva. En sus diferentes momentos, el pensamiento ha transitado de una determinación más abstracta a otra más concreta, con ello la reflexión ha ido, en diferentes grados de determinación (formal, real y absoluto) de la realidad efectiva de lo posible a lo contingente, y de lo contingente a lo necesario. En primera instancia, pensar la realidad efectiva implica pensarle como formalmente posible, pero pensar algo meramente posible es pensarlo como imposible, por lo que para ser realmente posible tiene que ser ya realmente efectivo y sólo puede ser realmente efectivo si es realmente posible, pero si es realmente posible y realmente efectivo a la vez, entonces es realmente necesario. Pero si no es más que lo realmente necesario lo que pone lo realmente posible y lo realmente efectivo como sus momentos, entonces es absolutamente necesario, y es aquello que puede pensar la contingencia siempre presente como un momento de sí en su autodeterminación.

Esto muestra que cada modalidad considerada en sí misma es insuficiente y está incompleta, la una sólo lo es por la otra. Ninguna determinación es por sí misma, cada una da luz a la otra. Pero sólo la necesidad absoluta puede dar cuenta de todas las anteriores como momentos suyos, es el pensamiento que se puede pensar en sus diferentes momentos.

Es el pensamiento, el que, a través de la reflexión, proporciona unidad a las cosas otorgándoles, con ello, verdadera efectividad y necesidad. No obstante, el introducir la necesidad en la cosa, no significa defender un ciego fatalismo,

\footnotetext{
${ }^{220}$ Ibíd., p. 619.
} 
sino hacer explícito que, sin la actividad reflexiva, la cosa carece de necesidad alguna (admitiendo que aún se pueda hablar de una tal cosa independientemente de la actividad de la reflexión). Toda necesidad atribuida a la cosa no es sino la necesidad que el pensamiento logra alcanzar en el proceso reflexivo que emprende sobre la cosa misma; proceso que es, a la vez, de comprensión y de constitución.

El orden hallado en la cosa no es sino el orden que el pensamiento construye en su esfuerzo por pensarla, pero no se trata de un orden al interior del mismo que luego se imponga sobre algo meramente exterior, sino que se trata de la construcción misma de la objetividad del mundo. El mundo no tiene orden alguno en sí mismo, hasta que eso que se presenta ahí es aprehendido como mundo pensado. En la aprehensión de eso que se le aparece de inmediato, el pensamiento va de las determinaciones más abstractas a las determinaciones más concretas hasta que logra darle una estructura completa. $\mathrm{Y}$ en tanto el mundo es estructurado en su plenitud por el pensamiento, éste se revela como la estructura misma del mundo.

El tipo de necesidad que muestran las cosas depende del grado en el que el pensamiento se halle presente y activo en las mismas. El grado de necesidad (ya sea formal, real o absoluta) que revele la cosa pensada está en función del grado de unidad que el pensamiento ha logrado en ella. En este sentido, mientras mayor sea la resistencia de la cosa a ser plenamente pensada, mayor será el carácter relativo de la necesidad. La necesidad será más relativa mientras más pobre sea la determinación lograda por el pensamiento en la cosa. Así, contrariamente a lo que comúnmente se piensa, Hegel no excluye la contingencia del mundo efectivo ${ }^{221}$; aunque dicha contingencia sólo puede ser pensada en y por medio de la necesidad (y será la actividad reflexiva del pensamiento la que, en última instancia, distinga lo efectivamente necesario de lo contingente).

\footnotetext{
${ }^{221}$ Es únicamente el punto de vista formal el que niega la presencia de la contingencia en la efectividad.
} 
Es en el esfuerzo por sintetizar la experiencia que el pensamiento, enfrentado a la contradicción, puede pensar lo contingente y lo necesario; es el encargado de constituir la necesidad de las cosas. Toda cosa es producto de la actividad del pensamiento, pero sólo aquella que es completamente constituida por la reflexión, es absolutamente necesaria. De ahí que sólo lo efectivo (Wirklich) sea racional, y no así lo meramente real (Realität). Sólo ahora se puede comprender que todo lo que es racional sea efectivo y que todo lo efectivo sea racional. 


\section{Implicación práctica de la realidad efectiva}

Hemos visto que en la Lógica hegeliana el mundo es lo que es sólo por la actividad del pensamiento. Cuando el pensamiento trata de pensar el mundo, no está sino constituyéndolo como tal. Pero no logra pensarlo de inmediato, pues se enfrenta de hecho con algo ahí real y, por tanto, no puede constituirlo de pronto, sino que requiere de un esfuerzo reflexivo. En su actividad reflexiva, el pensamiento va determinando la realidad en distintos grados, la va pensando bajo distintas modalidades que van de la más abstracta a la más concreta (estas modalidades, como ya hemos expuesto, son: posibilidad, contingencia y necesidad). Cada una de estas modalidades representa el grado de aprehensión que el pensamiento alcanza sobre el mundo con su actividad reflexiva y, al mismo tiempo, el modo en el que lo piensa constituido (pues, como hemos dicho, el mundo no es sino por su propia reflexión).

De este modo, mientras mayor sea el grado de aprehensión del mundo, el pensamiento tenderá a considerarlo más necesario; y mientras menor sea el grado, el pensamiento se inclinará a considerarlo más contingente. La necesidad del mundo se basa en el grado de aprehensión del mundo y, en consecuencia, de la constitución del mismo, ya que si puede ser completamente determinado en un todo coherente, entonces no puede ser de otra forma. Y esta es precisamente la definición de necesidad. No obstante, alguien podría decir que la necesidad se encuentra en el pensamiento, mientras que el mundo corre por el lado de la contingencia. Pero es precisamente Hegel el que nos ha insistido en que no existe por un lado el pensamiento y por el otro el mundo, que no hay una separación entre mundo inteligible y mundo sensible. No es que el pensamiento imponga una necesidad desde sí mismo en el mundo, sino que es el proceso de constituirlo como mundo pensado donde encuentra precisamente su necesidad. En este sentido, si la estructura del mundo es pensada como absolutamente necesaria, es porque el pensamiento ha logrado pensarla como tal; pues, como se ha dicho, el proceso de comprensión es, a la 
vez, un proceso de constitución. Es el proceso reflexivo del pensamiento el que, al concebir las cosas, las constituye como cosas y, al constituirlas en su plenitud, determina su necesidad absoluta.

\section{Necesidad y libertad}

La necesidad absoluta logra pensar la existencia necesaria de las cosas, y cuando reconoce que dicha necesidad no es sino resultado del proceso reflexivo, entonces ya no se está hablando tanto de necesidad como de libertad. ${ }^{222} \mathrm{En}$ su actividad libre, el pensamiento produce tanto la cosa (la existencia) como sus condiciones (la esencia), con lo que suprime todo presupuesto y, en consecuencia, alcanza su necesidad absoluta. ${ }^{223}$ La necesidad absoluta del mundo efectivo es el resultado de la actividad del pensamiento en su libertad (la libertad crea su propia necesidad, por lo que la necesidad no muestra sino la realización de la libertad).

Desde el punto de vista de Hegel no existe por un lado la necesidad y por otro el pensamiento. No hay una necesidad objetiva de cuya comprensión reflexiva surja la libertad, pues el pensamiento no se dirige a un mundo constituido ya como tal para luego descubrir la necesidad del mismo y, a través de ello, alcanzar la libertad. Para Hegel no existe necesidad fuera de la actividad del pensamiento. La necesidad absoluta es aquella necesidad que el pensamiento piensa en la cosa y encuentra en la misma en tanto cosa pensada.

${ }^{222}$ Con la subsunción de la necesidad real, la necesidad absoluta ha alcanzado la libertad. La libertad viene como resultado de la transición de la necesidad real a la necesidad absoluta. Pero la noción de libertad propiamente dicha entra únicamente después de atravesar por las tres relaciones del Absoluto: la "relación de sustancialidad", la "relación de causalidad" y la "interacción" (o el "efecto recíproco"). Estas tres relaciones no son sino las formas en las que es reconocida la unidad del Absoluto, como una unidad estructurada por la determinación del pensamiento.

223 Así, la necesidad absoluta, en cuanto actividad libre del pensamiento, se vincula a una concepción productiva (y no contemplativa) del conocimiento, esto es, a la producción de ideas verdaderas fundadas en la necesidad. La verdad se ve asociada entonces a la categoría de efectividad, que encuentra su pleno sentido en la necesidad absoluta. 
Cuando el pensamiento reconoce esta necesidad absoluta como mundo efectivo, entonces viene a ser libertad.

Lejos de excluir la libertad del dominio de la necesidad, la reflexión la funda sobre la necesidad absoluta misma, donde subjetividad y objetividad coinciden. Lo absolutamente necesario no depende ni sólo del sujeto (de la subjetividad del pensamiento) ni sólo del objeto (de una supuesta objetividad del mundo). La necesidad absoluta es incondicionada, y concebir y sumergirse en tal necesidad es alcanzar la libertad. Ser libre en este contexto es situarse más allá de lo trascendental y más acá de lo trascendente, es pensar sin presupuestos. Pues es la libre actividad reflexiva la que produce tanto las condiciones determinantes de la cosa como su unidad objetiva en la misma. La objetividad del mundo efectivo es el producto de la actividad reflexiva.

En el momento en el que la reflexión reconoce que todo el proceso que va desde la presuposición de las condiciones y de la cosa hasta la reconstitución de ambos en su unidad misma, no es sino la obra del pensamiento, entonces éste alcanza la necesidad absoluta. Y en tanto el pensamiento asume el proceso entero de reconstitución como su propia obra, se identifica con la libertad, pues es por sí mismo, y no por otro. Al autoconstituirse, el pensamiento deja de ser por algo ajeno a él mismo.

Se trata aquí de la libertad como pensamiento o del pensamiento como libertad. Pues es la libertad del pensamiento la fuente única de toda necesidad. No existe necesidad alguna antes de que pueda ser pensada, pues estrictamente la necesidad no es otra cosa que la reflexión del pensamiento sobre sí. No obstante, una vez que la necesidad es pensada como tal (esto es, como absoluta), entonces ya no es mera necesidad, sino libertad. Es el pensamiento en su libre despliegue inmanente. La libertad del pensamiento consiste en una autodeterminación y, en consecuencia, en una plena autoconstitución reflexiva. Se trata, pues, de una libertad absoluta, puesto que 
nada puede haber más libre que aquello que se constituye como pensamiento en el mismo movimiento de pensarse. El pensamiento constituye la cosa pensada en el mismo proceso de pensarla, y se constituye a sí mismo pensándose en el proceso mismo de constitución de la cosa como tal.

En su libertad, el pensamiento se piensa a sí y se constituye conforme a sí mismo, se piensa y se produce a sí mismo en sus actos: se sabe determinante y autodeterminado. Saberse autodeterminado es saberse a sí mismo en su otro (esto es, encontrarse en el otro en casa), y justo en esta reconciliación consiste la libertad. El pensamiento es libre cuando se sabe, a la vez, como esencia y como existencia; cuando se reconoce en un mismo movimiento como presupuesto y resultado, como causa y efecto de su propia actividad. Actividad que, arrojada al mundo, se resuelve en la necesidad del mundo efectivo.

Mediante su actividad reflexiva los seres humanos dotan de necesidad al mundo, el cual, de lo contrario, no hallaría ni sentido ni verdad por ningún lado. Aunque no es que la mera actividad reflexiva cree al mundo o le imponga una necesidad desde sí misma. Es en el encuentro con eso que aparece ahí, con lo que el pensamiento se pone en marcha, y es sólo también a través de la actividad práctica que el ser humano organiza con una estructura necesaria al mundo, transformándolo con su trabajo en un mundo humano. Es sólo a través de la acción teórica y práctica que puede ser pensada la necesidad de las cosas. En el plano lógico, la necesidad absoluta constituye, pues, la modalidad más alta que alcanza la reflexión, es así como el pensamiento especulativo ve las cosas.

Empero, aquella libertad del pensamiento hallada en el orden lógico sólo puede encontrar su verdad en su realización en el orden práctico. La libertad no se realiza sino en el devenir de lo real, esto es, en la historia, y lo hace bajo la forma del derecho (entendido en sentido lato). 
De este modo, la categoría de efectividad se vuelca sobre el orden histórico con el fin de sondear el orden práctico, esto es, la realización de la libertad que le otorga una necesidad absoluta al mundo efectivo. La absoluta necesidad de lo efectivo no puede quedarse en el orden puramente lógico, sino que tiene que ser realizada por la libertad en el orden práctico. Lo que dota de necesidad al mundo es su transformación por el trabajo de los seres humanos, quienes lo constituyen conforme a sus propias exigencias, lo van reconfigurando a la altura de sus necesidades.

La necesidad absoluta en el mundo efectivo no puede corroborarse en el mero ámbito de las ideas, se debe pasar del orden teórico al orden práctico. Con ello se alcanza la categoría de actividad (Tätigkeit). Esta categoría no se reduce al plano lógico, sino que va más allá, a la historia; pues lo efectivo se realiza concretamente sólo en el orden histórico. Desde la categoría de actividad se reconcilian ser y pensamiento, pero no ya desde el plano puramente teórico del pensamiento, sino desde el plano práctico del ser, de lo efectivo

La categoría de efectividad había ya mostrado que la unidad pensada de la cosa y sus condiciones, sólo se alcanza a través de un proceso reflexivo que la constituye como tal, y no así de manera inmediata. Lo mismo ocurre con el conocimiento histórico. Conocer en la historia es producir ideas verdaderas por medio de la actividad transformadora del pensamiento, es hacer inteligible un proceso que en sí mismo - si se pudiera concebir algo semejante- carecería de sentido, no tendría rumbo alguno. Dicha inteligibilidad no consiste en pasar a ideas una cosa que esté ya ahí, ni comprobar la preexistencia de una razón en el mundo que se ofrezca como dado, sino en producirlo en el movimiento mismo de pensarlo. Y pensarlo es transformarlo, pues tampoco hay una identificación inmediata entre el proceso histórico objetivo que se vive y el orden lógico del pensamiento que lo reflexiona; ambos van constituyéndose e identificándose en el mismo proceso. 
Así pues, en el conocimiento histórico, tanto las condiciones y su reunión en la cosa como la compresión de dicha unidad, son resultado de la actividad reflexiva sobre sus obras en el terreno práctico. En efecto, los seres humanos no sólo re-constituyen reflexivamente aquello a lo que se enfrentan (a lo que hacen objeto de experiencia), sino que ello es antes resultado de su propia actividad práctica. Ellos re-constituyen teóricamente el mundo que constituyen prácticamente. Los seres humanos no viven sino en un mundo humano hecho por humanos. Con sus actos, guiados desde luego por el pensamiento, crean al mundo tal como aparece, tal como parece habérseles ofrecido, y después tratan de fundamentarlo, tratan de encontrarle una razón de ser a su propia obra. Es entonces que el pensamiento reflexiona sobre sus productos y sobre sí mismo como inscrito en tales obras.

El mundo es resultado de la actividad teórico-práctica de los seres humanos, y fuera de ello no hay nada más. Hay todo menos pensamiento, y sin pensamiento ¿qué podría predicarse de algo?, ni siquiera la existencia de ese "algo". Nada se podría decir, pues no habría voz alguna.

La actividad humana es la que crea enteramente las condiciones de posibilidad del mundo, sin dejar sobrevivir presupuesto alguno. Toda posible enunciación sobre el mismo sólo es plausible en tanto se trata de un resultado, de una apropiación por medio de la actividad humana. Únicamente se puede hablar de un mundo efectivo ahí donde ha sido transformado por el trabajo y por el pensamiento humano. Veamos ahora cómo se realiza la categoría de efectividad en el orden práctico.

\section{Pensar la realidad efectiva}

En el orden lógico la categoría de realidad efectiva nos ha mostrado que el pensamiento, en su necesidad absoluta, se sabe determinante y autodeterminado, por lo que se autoconstituye como algo enteramente libre. Y 
este pensamiento que se autodermina libremente no es otra cosa que la razón. Efectivamente, de acuerdo con Hegel, <<la razón es el pensamiento, el nous, que se determina a sí mismo con entera libertad $\gg .{ }^{224}$ En el orden práctico la noción de efectividad nos mostrará que en su realización como algo enteramente libre, la razón se otorga su propia necesidad como mundo efectivamente presente. El mundo no es sino por la actividad libre de la razón que, al autodeterminarse, se hace mundo efectivo. Así, de acuerdo con nuestro autor, "la razón rige el mundo", y dentro de las figuras que ésta adopta, en ninguna es más manifiesta que en el espíritu de un pueblo. ${ }^{225}$ Es en la vida ética de un pueblo que la razón se muestra efectivamente realizada.

En medio de los acontecimientos históricos de su tiempo, Hegel considera el estallido revolucionario de 1789 en Francia como la realización de la razón, pues ve en dicho estallido la posibilidad de reconciliación, perseguida en la Modernidad, de la libertad individual con la libertad de la vida en común (aunque ello sea sólo en un principio, ya que posteriormente verá en los resultados de dicha revolución la decadencia de aquellos principios que ella misma había promovido). Hegel concibe a la Revolución francesa como la culminación de la Ilustración, como el punto más álgido de las contradicciones inherentes al mundo moderno. La Ilustración representa la cima del proceso de autoconsciencia del ser humano, pues en ella éste hace consciente que posee una voluntad racional con la que puede transformar todo aquello que se le presenta en la experiencia inmediata. La conciencia ilustrada se planta con una postura crítica frente a lo meramente existente y cuestiona toda autoridad fundada en el pasado así como en un orden natural o divino.

No obstante, deslumbrada por la luz del entendimiento, la conciencia ilustrada no alcanza a vislumbrar que el agente portador de voluntad racional

${ }^{224}$ G. W. F. Hegel, Lecciones sobre filosofía de la historia universal (Madrid: Alianza, 1989), p. 50.

$225<<$ Lo racional es el ser en sí y por sí, mediante el cual todo tiene su valor. Se da a sí mismo diversas figuras; en ninguna es más claramente fin que en aquella en que el espíritu se explicita y manifiesta en las figuras multiformes que llamamos pueblos〉>. Ibíd., p. 44 
no es sino vehículo de la razón misma que se autoconstituye en la historia. Y en tanto el entendimiento únicamente concibe esta voluntad racional como una pura forma abstracta, resulta incapaz de hallar un contenido concreto para la misma. De modo que dicha voluntad sólo se puede mostrar en la existencia a través de la destrucción, con lo que acaba por destruir sus propias creaciones y, en última instancia, termina por destruirse a sí misma. Efectivamente, esta voluntad piensa que únicamente se puede concebir a sí misma como verdadera libertad en la medida en que se coloca como absoluta... bajo el sello de la destrucción. Es así que tras la Revolución francesa esta libertad abstracta, puesta como algo absoluto, hizo aparecer el terror político, el cual se encargó de avasallar a los "enemigos del pueblo" en nombre de una "voluntad real". ${ }^{226}$ Sin embargo, las devastadoras consecuencias de esta revuelta cumplieron su propia función: la Revolución francesa, tras su destrucción, constituye un momento necesario que sentó las bases para la consumación del orden estatal moderno. Detengámonos, pues, por un momento en la concepción que Hegel sostiene sobre el Estado moderno.

Es principalmente en su obra intitulada Principios de la filosofía del derecho donde Hegel aborda con mayor amplitud la institución del orden estatal, pero en esta obra trata de ver sobre todo cómo es que se realiza la libertad en el mundo efectivo, por lo que dicha obra parte de la noción de voluntad. Hegel habla específicamente de voluntad racional (o humana), ya que el ser humano es el único ente dotado de voluntad. Los objetos en el mundo no poseen ningún fin en sí mismos, es la voluntad la que, transformándolos conforme a sus propios principios, les otorga una finalidad. La voluntad adquiere así derechos sobre los objetos. El sujeto, como voluntad individual, adquiere el derecho de propiedad privada, tal derecho privado será denominado "derecho abstracto", en el cual entran en juego las nociones de contrato, delito y

${ }^{226}$ De acuerdo con Hegel, <<sólo destruyendo algo tiene esta voluntad negativa el sentimiento de su existencia [...] A ella corresponde por ejemplo el período del terror en la Revolución francesa, en el que se debía eliminar toda diferencia basada en el talento o en la autoridad〉>. G.W. F. Hegel, Principios de la filosofía del derecho (Barcelona: Edhasa, 1999), pp. 82-83. 
lesión (castigo). El contrato representa la adquisición reconocida de la propiedad ${ }^{227}$; el delito, a su vez, constituye la negación de dicha propiedad, por lo que va en contra del derecho de propiedad en general, esto es, tanto de las víctimas como del delincuente mismo ${ }^{228}$; y la lesión, por su parte, tiene como finalidad enmendar la voluntad del delincuente por haber negado la propiedad.229 En este sentido la lesión sirve para enmendar al delincuente, pues aplicarle el castigo correspondiente por el delito cometido significa dignificarle como sujeto de voluntad. De ahí que la lesión (castigo) constituya un derecho para el delincuente mismo. 230

No obstante, para que el castigo no se convierta en venganza y devenga en una nueva injusticia - convirtiendo ahora al victimario en víctima-, es menester la existencia de principios no sólo externos (como el derecho abstracto de violencia), sino internos (que apunten a la universalidad de la justicia); además, es necesario que se establezca un derecho penal para atender la injusticia. ${ }^{231}$ En efecto, como hemos dicho, Hegel parte de la noción de voluntad que trata de ser realizada en el mundo efectivo, y si bien esta voluntad es expresada externamente por el derecho abstracto, ahora requiere ser fundada

${ }^{227}$ La propiedad <<en cuanto existencia de la voluntad es, en cuanto para otro, sólo para la voluntad de otra persona [...] Esta mediación por la que se tiene una propiedad no sólo mediante una cosa y mi voluntad subjetiva, sino al mismo tiempo mediante otra voluntad y por lo tanto en una voluntad común, constituye la esfera del contrato >>. Ibíd., p. 160.

$228<<$ La primera violencia ejercida como fuerza por el individuo libre, que lesiona la existencia de la libertad en su sentido concreto, el derecho en cuanto derecho, es el delito. Es un juicio negativo infinito en su sentido completo [...] mediante el cual no sólo se niega lo particular, la subsunción de una cosa bajo mi voluntad, sino también lo universal, lo infinito en el predicado de lo mío, es decir, que se niega no sólo la capacidad jurídica, sin la mediación de mi opinión [...] sino precisamente en contra de ella $>$. Ibíd., pp. 181-182.

${ }^{229}<<$ La lesión es [...] para la voluntad particular del lesionado y de los demás, sólo algo negativo. Su única existencia positiva es como voluntad particular del delincuente. La lesión de ésta en cuanto voluntad existente es por lo tanto la eliminación del delito — que de otro modo sería válido- y la restauración del derecho〉. Ibíd., p. 185.

$230<<$ La lesión que afecta al delincuente no es sólo justa en sí; por ser justa es al mismo tiempo su voluntad existente en sí, una existencia de su libertad, su derecho. Es por lo tanto un derecho en el delincuente mismo, es decir, puesto en su voluntad existente, en su acción. En efecto, en su acción, en cuanto acción de un ser racional, está implícito que es algo universal, que por su intermedio se formula una ley que él se ha reconocido en ella para sí y bajo la cual puede por lo tanto ser subsumido como bajo su derecho>>. Ibíd., p. 187.

$231<<$ La exigencia de resolver esta contradicción que se presenta en la manera de eliminar la injusticia [...] es la exigencia de una justicia no vengativa sino punitiva. Se tiene aquí, en primer lugar, la exigencia de una voluntad que, en cuanto voluntad subjetiva particular, quiere lo universal como tal>>. Ibíd., p. 193. 
internamente. Es en este sentido que aparece el momento de la moralidad (Moralität), el cual constituye la realidad concreta de la libertad. ${ }^{232}$

Ahora bien, en tanto el individuo posee voluntad, es primeramente un ser natural que busca satisfacer sus necesidades (pasiones, inclinaciones, deseos); no obstante, para abandonar este carácter puramente natural, el individuo debe dar un orden a su voluntad, por lo que tiene el deber de determinarse a sí mismo dando un contenido racional a su propia voluntad. De este modo la moralidad, al establecer un orden interno en la voluntad, acaba con el déficit dejado por el derecho abstracto. Hegel coloca dentro de este terreno de la moralidad a la razón práctica de Kant, la cual debe autolegislarse para otorgarse una ley universal y necesaria. Ley que en tanto es autoimpuesta por el propio individuo, se le presenta a éste como una obligación, esto es, como un imperativo categórico, pues es lo único que puede otorgarle verdadera autonomía.

Empero, aunque Hegel parte de la autonomía moral kantiana, se distancia de Kant al plantear que la moralidad requiere ser entendida desde las prácticas de la vida en común, pues si el sujeto moral se desentiende de tal mundo externo y se recluye en la mera consciencia, ésta queda entonces vacía. Así, para nuestro autor, la obligación moral kantiana se halla vaciada de todo contenido, se presenta como algo meramente formal y abstracto que se queda en una simple aspiración (en un deber ser), que trata de definirse en contraste con lo realmente existente (con el ser). ${ }^{233}$ Pero para Hegel la mera voluntad individual, en su aislamiento, no puede derivar ninguna noción de bien moral.

${ }^{232}$ La moralidad <<consiste en superar la voluntad que en un primer momento sólo existe por sí y sólo en sí es idéntica a la voluntad existente en sí o voluntad universal; al eliminar esta diferencia en la que se ha hundido pone a la voluntad por sí como idéntica a la voluntad existente en sí. Este movimiento es el cultivo del nuevo terreno que ha alcanzado la libertad: la subjetividad. Por medio de esta elaboración, la subjetividad, que en un primer momento es abstracta y diferente del concepto, se iguala con él, y la idea alcanza su realización verdadera al determinarse la voluntad subjetiva al mismo tiempo como objetiva y por lo tanto verdaderamente concreta〉>. Ibíd., pp. 199-200.

${ }^{233}$ Hay una contraposición entre ser y deber ser o, en otros términos, entre naturaleza y moralidad, entre necesidad y libertad. 
Por el contrario, para nuestro autor, únicamente aquella voluntad que se inscribe en la comunidad puede desarrollar una noción de bien moral (cuyo contenido pueda también convertirse en un deber, pero esta vez no un deber fundado en la mera razón formal, sino que surja de una razón encarnada en la comunidad). De tal manera que aquella exigencia planteada por la moralidad lleva más allá de sí misma, esto es, a la noción de comunidad, ya que es ésta la única que puede dar un contenido concreto al sujeto moral. El contenido de la moralidad no proviene entonces sino de la comunidad a la que pertenecen el sujeto como voluntad libre.

La filosofía hegeliana se basa, pues, en la voluntad libre que se realiza en la vida en común. De hecho Hegel piensa que la voluntad es la manifestación práctica del pensamiento, por lo que está destinada a ser libre. ${ }^{234}$ Pero esta voluntad ha de hacerse libre, no aislándose del mundo (pues de esta manera es imposible que se realice como tal), sino enmarcándose en un contexto social. Los sujetos no pueden identificarse entonces sólo consigo mismos, sino que han de hacerlo con una vida espiritual superior, con una vida social. Esta vida en común que es la sociedad se funda en deberes, lo cuales se le han de presentar al sujeto como una obligación; pero no una obligación sólo para consigo mismo, sino frente a la comunidad a la que pertenece. El conjunto de tales deberes, basados en normas y usos establecidos, es decir, en costumbres (Sitten), es a lo que nuestro autor llama eticidad (Sittlichkeit).

La eticidad se muestra, según Hegel, en las instituciones y leyes que regulan la vida en común de un pueblo, por lo que ella "se eleva por encima de la opinión subjetiva y del capricho". Así, la vida pública de una sociedad está compuesta de instituciones y leyes, las cuales requieren ser vividas para

\footnotetext{
${ }^{234}$ Nuestro autor sostiene incluso que en la unidad consigo, el pensamiento mismo viene a ser la libertad misma, pues con esta relación consigo él crea su propio contenido a partir de sí mismo. De esta manera, se puede decir que ser libre es ser determinado por una ley propia, por una norma autoimpuesta, pero esta autodeterminación se alcanza sólo mediante un proceso de extrañamiento y reconciliación que va desde una unidad inmediata de la voluntad hasta la unidad mediada de la misma. En este sentido, la autonomía (o autodeterminación) solamente se alcanza con la salida de sí y con la vuelta a sí de la voluntad.
} 
mantenerse, y cuando en su actuar los sujetos reconocen las normas de la vida social como algo propio (cuando se identifican con las normas que practican en), se alcanza entonces la eticidad. ${ }^{235}$ En ella las acciones de los sujetos son conforme a las normas sociales (y sólo estas acciones pueden indicar qué norma debe aún ser mantenida en situaciones ulteriores, y cuál, por el contrario, resulta ya obsoleta). Podemos ver aquí que mientras la moralidad, fundada en la voluntad individual, se contraponía a lo que es y planteaba en su lugar un deber ser; la eticidad, con fundamento en la vida en común, no se ocupa de la formulación de lo que debería ser, sino de lo que es (no hay una separación entre ser y deber ser, éste ya está de alguna manera realizado en aquél). ${ }^{236}$ Las normas que existen de hecho en la vida ética dan ya las bases para la acción.

De este modo, las normas de la eticidad son implícitas ${ }^{237}$, se dan en la práctica sin una formulación teórica previa por parte de los sujetos. Al identificarse con una vida ética, los sujetos actúan como por instinto, por lo que la eticidad puede ser vista como una "segunda naturaleza".238 Al actuar conforme a su vida ética, los sujetos alcanzan su verdadera libertad, alcanzan una libertad sustancial, que no es sino la realización de sí mismos como autoconciencia libre 239 (nótese que se trata de una realización efectiva, y no de un mero deber como en la moral).

${ }^{235}$ En el mundo ético hay una identificación entre el sujeto y las normas que regulan sus prácticas e instituciones; en otras palabras, hay una identificación entre el sujeto y su comunidad.

${ }^{236}$ A partir de ello se puede decir que la realidad es ya, en cierto modo, racional; de ahí que para nuestro autor no hay necesidad de construir modelos utópicos para la sociedad.

${ }^{237}<<[\ldots]$ estas leyes éticas no son para el sujeto algo extraño, sino que en ellas aparece como en $s u$ propia esencia el testimonio del espíritu. Ahí tiene su orgullo y vive en su elemento, que no se diferencia de sí mismo. Es una relación que inmediatamente resulta aún más idéntica que la de la fe y la confianza >. Ibíd., p. 267.

238 <<En la identidad simple con la realidad de los individuos, lo ético, en cuanto modo de actuar universal de los mismos, aparece como costumbre. El hábito de lo ético se convierte en una segunda naturaleza que ocupa el lugar de la primera voluntad meramente natural y es el alma, el significado y la efectiva realidad de su existencia. Es el espíritu que existe y vive en la forma de un mundo, el espíritu cuya sustancia es por primera vez como espíritu〉> Ibíd., p. 272.

$239<<$ La eticidad es la idea de la libertad como bien viviente que tiene en la autoconsciencia su saber, su querer y, por medio de su actuar, su realidad; actuar que tiene a su vez en el ser ético su fundamento en y por sí y su fin motor. Es el concepto de la libertad que ha devenido mundo existente y naturaleza de la autoconsciencia >>. Ibíd., p. 265. 
Desde el punto de vista de la eticidad, la moralidad solamente alcanza su concreción en la comunidad, en la vida propiamente ética. Así, la eticidad constituye la más elevada realización de la vida moral. De hecho la eticidad incorpora dentro de sí tanto la moral como el derecho. Y en tanto unión de moralidad (subjetividad) y derecho (bien), $240<<$ la eticidad ha sido representada como la justicia eterna de los pueblos, como los dioses existentes en y por sí, frente a los cuales los vanos movimientos de los individuos no pasan de ser un juego >>.241 Pero en el desarrollo de la eticidad se hallan tres formas de vida en común que guardan entre sí un orden lógico ascendente: la familia, la sociedad civil y el Estado.

De acuerdo con Hegel, la familia es ya una forma de vida en común, pero se trata de una unidad que se basa sólo en el sentimiento, por lo que en ella los sujetos se ven relacionados por vínculos meramente internos. Empero, en la familia los sujetos se conciben ya a sí mismos como miembros de algo más grande, como pertenecientes a una cierta forma de vida en común que constituye parte de su identidad (en esto radica la importancia de la familia, ya que, como parte de la eticidad, lleva a la consciencia de pertenecer a algo más grande, aunque esta consciencia se dé aún sólo por sentimiento, y no propiamente por la razón). Con relación a la familia, Hegel toca los temas del matrimonio, la propiedad familiar y la educación de los hijos. Pero cabe destacar que en estas relaciones los individuos no se ven entre sí como sujetos de derechos. De hecho la familia se disuelve en el momento en el que sus relaciones se rigen bajo el derecho. Y esta vida en la que los individuos aparecen como sujetos de derechos constituye la siguiente figura de la eticidad, la sociedad civil.

\footnotetext{
$240<<$ Pero la integración de ambas totalidades relativas [bien y subjetividad] en la absoluta identidad ya está realizada en sí, puesto que la subjetividad de la pura certeza de sí misma que desaparece por sí en su vanidad es idéntica con la universalidad abstracta del bien. La identidad concreta del bien y la voluntad subjetiva, su verdad, es la eticidad>>. Ibíd., p. 259.

${ }^{241}$ Ibíd., p. 266.
} 
La sociedad civil es una forma de vida en común en la que los individuos se hallan unidos por necesidad recíproca, pues se trata de una comunidad de producción e intercambio entre los mismos, por lo que representa el ámbito donde se desarrollan sus relaciones económicas. En la sociedad civil el individuo se halla vinculado con los demás de forma meramente externa, sin ningún otro lazo (como lo era el sentimiento en el caso de la familia), ello lleva al individuo a tomar consciencia de su particularidad como persona.

En la esfera de la sociedad civil los individuos son considerados pues como personas, esto es, como sujetos con intereses meramente individuales y, por ende, como sujetos de necesidades tanto materiales como espirituales. ${ }^{242}$ En dicha sociedad, los individuos pretenden satisfacer sus necesidades por medio su propio trabajo, no obstante, la satisfacción de tales necesidades en realidad requiere de la cooperación de todos, ya que resulta imposible que un individuo satisfaga por sí mismo su amplia gama de necesidades, que además siempre va en aumento. En la satisfacción de sus necesidades, el individuo requiere de los demás, es un ser necesitado; y al existir una dependencia mutua entre los individuos, deben entrar necesariamente en el intercambio. De este modo, la satisfacción de las necesidades individuales lleva también a la satisfacción de las necesidades de los otros. ${ }^{243}$

La sociedad civil representa entonces un sistema de necesidades ${ }^{244}$; pero se trata, por cierto, de un sistema dinámico, ya que tales necesidades se multiplican y, con ello, también se hace necesario multiplicar los medios para

$242<<$ La persona concreta que es para sí misma un fin particular, en cuanto totalidad de necesidades [...] y mezcla de necesidad [...] natural y arbitrio, es uno de los principios de la sociedad civil〉>. Ibíd., p. 303.

$243<<$ En esta dependencia y reciprocidad del trabajo y de la satisfacción de las necesidades, el egoísmo subjetivo se transforma en una contribución a la satisfacción de las necesidades de todos los demás. Se convierte en la mediación de lo particular por lo universal, en el movimiento dialéctico en el que cada uno, al ganar, producir y gozar para sí, produce y gana para el goce de los demás〉>. Ibíd., p 319.

$244<<$ En su relación, el fin egoísta, condicionado de ese modo por la universalidad, funda un sistema de dependencia multilateral por el cual la subsistencia, el bienestar y la existencia jurídica del particular se entrelazan con la subsistencia, el bienestar y el derecho de todos, se fundamentan en ellos y sólo en ese contexto están asegurados y son efectivamente reales. Se puede considerar este sistema en primer lugar como Estado exterior, como el Estado de la necesidad y del entendimiento〉>. Ibíd., p. 304. 
su satisfacción. Pero en este sentido la multiplicación de necesidades conlleva una mayor cooperación social para una mayor producción; más producción requiere, a su vez, mayor división del trabajo. Se desarrolla así un sistema de relaciones de interdependencia altamente complejo. El desarrollo de una cooperación social más intensa y compleja lleva a una dependencia recíproca total, ya que todos dependen de todos (de modo que la supuesta autosuficiencia de las partes es sólo relativa).

Esta total interdependencia dentro de la sociedad civil, que contiene una mayor división del trabajo, lleva a la formación de ciertos grupos sociales que, además de tener un tipo de trabajo distinto, tiene también diferentes formas de vida. Hegel se refiere a estos grupos con el término de "clases" (Klassen), éstas son tres, a saber: la clase sustancial (agrícola), la clase industrial (comerciante) y la clase universal (burócrata). De modo que son estas tres clases las que articulan la sociedad civil. ${ }^{245}$

Estas diferentes clases de la sociedad civil entran en relación a través del intercambio y la producción de los medios indispensables para la satisfacción de sus necesidades, por lo que para garantizar el derecho de todo sujeto en dicha relación, la propia comunidad debe desarrollar una cierta administración de la justicia. Es menester que el poder público intervenga, mediante la administración de la justicia, para generar una cierta regulación económica, ya que el mero intercambio generalizado entre los individuos no basta para asegurar el orden social. ${ }^{246}$ Hegel piensa que dentro de la propia sociedad civil se desarrolla un cierto poder público con determinadas funciones "jurídicas" y "políticas", por lo que en ella es posible una regulación de la vida social a través

${ }^{245}$ La sociedad civil se articula así en tres clases, la primera, la clase sustancial, tiene una consciencia irreflexiva de su pertenencia a la universalidad, vive cercana a la naturaleza y lleva una vida ética inmediata fundada en la relación familiar con base en la confianza. La segunda, la clase industrial, tiene una consciencia reflexiva de su pertenencia a lo universal, su vida se basa en la satisfacción del individuo a través del trabajo propio. Y la tercera, la clase universal, tiene una consciencia razonada de su identificación con lo universal, es la clase de los servidores públicos que encarna los intereses de la comunidad.

${ }^{246}$ Con respecto a los sujetos, sólo <<es la intervención directa desde arriba lo que los reconduce permanentemente a la finalidad del todo y los limita de acuerdo con ella [...] imponiendo al mismo tiempo prestaciones directas para su conservación〉>. Ibíd., p. 423. 
de ciertas corporaciones. Sin embargo, nuestro autor también advierte sobre los problemas intrínsecos a la sociedad civil que le hacen tender hacia su propia disolución.

En efecto, el libre desarrollo de la sociedad civil lleva a un aumento de la producción - que en algunos casos deriva en un problema de sobreproducción, problema que por cierto pretende ser desplazado al mercado externo para su resolución-, lo cual genera una mayor división del trabajo. Esta división social trae consigo el enriquecimiento de pocos con el paralelo empobrecimiento de muchos. Aquellos sujetos que se ven llevados a la pobreza, no empobrecen sólo materialmente sino también espiritualmente, ya que el mismo trabajo les conduce a una situación ignominiosa. Surge así aquello que Hegel denomina la plebe. ${ }^{247}$

Así, en su desarrollo, la sociedad civil, al modo de la sociedad burguesa, ofrece $<<$ el espectáculo de libertinaje y miseria, con la corrupción física y ética que es común a ambas. El desarrollo independiente de la particularidad [...] es el momento que señala en los antiguos Estados el comienzo de la corrupción de las costumbres y la razón última de su decadencia >>. ${ }^{248}$ Hegel compara esta corrupción del orden político antiguo con la corrupción sufrida en la Modernidad, ya que al igual que la sociedad antigua, la sociedad civil moderna también tiende a la particularidad y, por ende, a su destrucción (yace aquí una contradicción puesto que a pesar de los grandes beneficios que produce la sociedad civil, sus miembros sólo miran por el interés propio, donde sólo algunos resultan beneficiados; al adolecer de este problema de particularismo, dicha sociedad se socava a sí misma; particularismo que, por cierto, comparte

\footnotetext{
$247<<$ La caída de una gran masa por debajo de un cierto nivel mínimo de subsistencia, que se regula por sí solo como el nivel necesario para un miembro de la sociedad, y la pérdida consiguiente del sentimiento del derecho, de lo jurídico y del honor de existir por su propia actividad y trabajo, lleva al surgimiento de una plebe, que por su parte proporciona la mayor facilidad para que se concentren en pocas manos riquezas desproporcionadas [...] Se manifiesta aquí que en medio del exceso de riqueza la sociedad civil no es suficientemente rica, es decir, no posee bienes propios suficientes para impedir el exceso de la pobreza y la formación de la plebe>> Ibíd., pp. 359-360.

${ }^{248}$ Ibíd., pp. 305-306.
} 
con la sociedad burguesa, donde la acumulación de enorme riqueza en manos de particulares contrasta con la pobreza general de la población).

De esta manera se puede observar que, en un primer momento, la sociedad civil puede hacer frente a sus problemáticas mediante mecanismos propios, esto es, a través de una especie de autorregulación que se crea a partir de la constante tensión entre los grupos opuestos que la articulan; en un segundo momento, se hace patente que una sociedad tal, llena de conflicto y antagonismo, no puede sostenerse a sí misma. La sociedad civil no puede autorregularse de modo pleno, por lo que sus dificultades sólo pueden ser superadas en una forma de organización civil superior que se base en el poder político.

La sociedad civil, al no ser una sociedad propiamente política, se ve marcada por los intereses particulares de las personas privadas, que sólo entran en relación para la satisfacción de sus necesidades. Es de este modo que dicha sociedad se ve dominada por el mero arbitrio particular; existe en ella una escisión de la vida ética que constituía la sustancia del individuo (esta vida en común que constituye su propia sustancialidad se ve destronada por las mismas personas privadas que atienden sólo a su particularismo).

De ahí que la sociedad civil se caracterice justo por la pérdida de eticidad. ${ }^{249}$ Pero en tanto la sociedad civil se presenta como un espacio lleno de contradicciones, es incapaz de sostenerse a sí misma, por lo que requiere fundarse en un orden estatal que devuelva la eticidad a la vida social. De modo que para Hegel la sociedad civil sólo encuentra su verdad en el Estado. Éste constituye la mediación de las contradicciones de dicha sociedad y, en

249 <<Como espíritu que se particulariza abstractamente en muchas personas [...] en familias o singulares que con libertad autosuficiente y como particulares son para sí, la sustancia pierde primero su determinación ética, por cuanto estas personas como tales no tienen como fin suyo a la unidad absoluta, sino que tienen en su consciencia su propia particularidad y su ser-para-sí, y los tienen como fin suyo: el sistema del atomismo>>. G. W. F. Hegel, Enciclopedia de las ciencias filosóficas (Madrid: Alianza, 1999), p. 542. 
consecuencia, su resolución. El Estado será para nuestro autor la realización plena de la eticidad.

Pero cabe resaltar que son las mismas contradicciones de la vida civil las que generan la necesidad de un orden estatal que resuelva tales conflictos y haga prevalecer una vida ética. Como se ha dicho con anterioridad, la eticidad expresa la anhelada identificación entre el individuo y su comunidad. La eticidad identifica al individuo con la comunidad a la que pertenece, ya que ésta no es vivida por aquél como algo extraño, sino como aquello que lo hace ser un ciudadano libre.

En este sentido, en tanto el fin último de la eticidad es la acción libre, la filosofía política de Hegel es una filosofía de la libertad. ${ }^{250}$ La filosofía hegeliana constituye el esfuerzo teórico por encontrar la libertad realizada en el orden práctico. Sin embargo, es necesario hacer una distinción entre la conciencia de la libertad y la realización de la misma, ya que una cosa es el principio de la libertad y otra su penetración y desenvolvimiento en el mundo 251 (de ahí que aun pudiendo ser conscientes de nuestra libertad podemos permanecer de hecho en la esclavitud).

Se genera, entonces, una diferencia entre la consciencia de la libertad y su realización efectiva, y es sólo en esta realización que el ser humano se constituye como tal ${ }^{252}$, pues $<<$ si es cierto que el embrión es en sí un ser humano, no lo es, sin embargo, para sí; para sí el ser humano sólo lo es en cuanto razón cultivada que se ha hecho a sí misma lo que es en sí>>.253 Es su

\footnotetext{
${ }^{250}$ A diferencia de la Antigüedad, es en la Modernidad donde, de acuerdo con Hegel, surge por primera vez la consciencia de la libertad universal, y ésta no surge sino con la religión cristiana: <<sólo las naciones germánicas — dice nuestro autor - han llegado, en el cristianismo, a la consciencia de que el hombre es libre como hombre, de que la libertad del espíritu constituye su más propia naturaleza>>. G. W. F. Hegel, Lecciones sobre filosofía de la historia universal (Madrid: Alianza, 1985), p. 67.

251 Aunque el ser humano es libre por su mera condición de ser humano, primeramente es libre en sí (tiene la consciencia de su libertad), pero aún no lo es para sí (no ha realizado su libertad en el mundo efectivo).

${ }^{252}$ El ser humano sólo se constituye como tal (como humano) en tanto realiza su libertad, pues $<<$ el hombre es su acto, es la serie de sus actos, es aquello para lo cual se ha hecho>>. Ibíd., p. 103.

${ }^{253}$ G. W. F. Hegel, Fenomenología del espíritu (México: FCE, 1966), p. 17.
} 
libre acción lo que lo constituye como propiamente humano (en términos hegelianos, como algo en y para sî). A través de su libertad el ser humano se humaniza, se cultiva como tal, se torna razón cultivada.

No obstante, la realización de la libertad para el cultivo de la razón requiere de un proceso arduo y paulatino a través de la historia. De modo que las fases de realización de la libertad en el mundo no constituyen sino la historia humana misma, por ello se puede decir que $<<$ la historia universal es el progreso en la consciencia de la libertad $\gg>.254$ En efecto, la historia constituye aquel largo proceso por el que el pensamiento toma consciencia de que es la libertad el principio que organiza y ha organizado al mundo. En este sentido, el objetivo de la historia consiste en que el individuo llegue a la consciencia de su libertad y que, con ello, "se ponga fines universales y los haga valer" (con su filosofía, Hegel pretende conducirnos al saber sobre el progreso de la consciencia hacia la libertad).

Sin embargo, cabe señalar que para nuestro autor la conciencia de la libertad sólo se da en relación con los otros. De esta manera, la consciencia sólo halla su verdad en otra consciencia que la reconoce como tal y la conduce, con ello, a un saber de sí como autoconsciencia. ${ }^{255}$ Se trata aquí de un yo que no es sino en un nosotros y, a su vez, de un nosotros contenido en el yo. ${ }^{256}$ Así, en la filosofía hegeliana, la libertad no debe ser entendida abstractamente, sino dentro de la vida espiritual concreta ${ }^{257}$, ya que "sólo lo espiritual es lo real".

${ }^{254}$ Ibíd., p. 68.

255 Esta autoconsciencia contiene, pues, la contradicción: es la afirmación de la consciencia, ulteriormente negada por otra consciencia, y cuya negación deviene en la síntesis de la autoconsciencia (se trata entonces de la negación de la negación como afirmación).

${ }^{256}$ Se trata de concebir que aquello (el otro) que primeramente constituía la negación de mí mismo (el $y o$ ), es negado por una relación más alta que deviene en un mutuo reconocimiento (el nosotros). En otras palabras, este proceso<<consiste en intuir en la independencia del otro la perfecta unidad con él〉>. Ibíd., p. 209.

257 < <La manifestación del espíritu es su determinación; y este es el elemento de su naturaleza concreta. El espíritu que no se determina es una abstracción del intelecto. La manifestación de espíritu es su autodeterminación>>. Ibíd., p. 103. 
De hecho, lo que Hegel llama espíritu no es más que la libertad realizándose a sí misma en la historia, por lo que "el único fin del espíritu" es la realización concreta (real) de la libertad: <<es un fin absoluto de la razón que la libertad sea efectivamente real $>.{ }^{258}$ El fin sustantivo del espíritu es la realización de la voluntad libre, ya que para nuestro autor "el distintivo del espíritu es su acto, su actuosidad”. El espíritu es la conciencia que se torna autoconsciente de su libertad. La filosofía de Hegel tiene como propósito conducir a la voluntad a tomar conciencia de su libertad, esto es, a la autoconciencia, que no es sino el saber de sí del propio espíritu. En este sentido su filosofía trata de llevar "al espíritu autoconsciente mismo": <<el fin último del mundo, es que el espíritu tenga consciencia de su libertad y que de este modo su libertad se realice >>.259 Pero la libertad, como presencia viva del espíritu, se realiza sólo en un "pueblo libre".

El individuo, en tanto voluntad libre, sólo se sabe como autoconsciencia en las costumbres y leyes de un pueblo, $<<$ las leyes son lo que cada singular es y hace; el individuo no sólo las reconoce como su coseidad objetiva universal, sino que se reconoce a sí mismo en ella, o se reconoce como singularizado en su propia individualidad y en cada uno de sus conciudadanos $>>.260$ La realización del individuo como autoconsciencia (esto es, como "razón consciente de sî") encuentra su plena realidad en la "vida de un pueblo", en la vida institucionalizada de una comunidad.

De ahí que aquella comunidad que se constituye como un orden estatal demande preceptos y leyes, así como decisiones generales y válidas para la misma comunidad en general. $\mathrm{Y}$ en tanto son válidas para cada uno, cuando un sujeto (como voluntad libre) <<se somete a las leyes, desaparece la oposición entre la libertad y la necesidad. Necesario es lo racional, como sustancia; y somos libres por cuanto lo reconocemos como ley y lo seguimos como sustancia

\footnotetext{
${ }^{258}$ G. W. F. Hegel, Principios de la filosofía del derecho (Barcelona: Edhasa, 1999), p. 375.

${ }^{259}$ G. W. F. Hegel, Lecciones sobre filosofía de la historia universal (Madrid: Alianza, 1985), p. 68.

${ }^{260}$ G. W. F. Hegel, Fenomenología del espíritu (México: FCE, 1966), p. 210.
} 
de nuestra propia esencia $>>.261$ De modo que $<<$ la ley es la objetividad del espíritu y la voluntad en su verdad; y sólo la voluntad que obedece a la ley es libre, pues se obedece a sí misma y permanece en sí misma y es, por tanto, libre $>>.262$

Es sólo en la vida en común, o vida ética (como "unidad espiritual absoluta"), donde al obedecer la ley la voluntad se hace libre. Es sólo siguiendo las normas de la comunidad que el individuo particular alcanza su libertad, pues de hecho $<<$ lo que el individuo hace es la capacidad y el hábito ético universales de todos $>>263$. De ahí que los antiguos sabios afirmaran: "la sabiduría y la virtud consisten en vivir de acuerdo con las costumbres de su pueblo". Así, Hegel se enfrenta al problema político fundamental al que se enfrentó Rousseau, a saber: la conciliación (o reconciliación en el caso del primero) entre la ley y la libertad.

En tanto considera que la ley no es sino la realización misma de la libertad, la filosofía hegeliana se ve vinculada a la razón práctica de Kant, pero también, y sobre todo, a la doctrina social de Rousseau, ya que éste es el primer pensador que pone como principio esencial aquella "naturaleza recóndita" según palabras de Kant- del ser humano: la facultad de elegir, esto es, la voluntad. 264 De este modo, $<<$ Rousseau ha tenido el mérito - dice Hegel- de establecer como principio del Estado un principio que no sólo según su forma [...] sino también su contenido, es pensamiento y, en realidad, el pensar mismo: la voluntad $>>.265$ Empero, a pesar de que el autor del Contrato social trata de llevarnos a la consciencia de la libertad, de una libertad que se reconoce en sus obras, es Hegel el que trata de conducirnos, a su vez, a la consciencia misma de esa consciencia, esto es, a la autoconsciencia.

\footnotetext{
${ }^{261}$ G. W. F. Hegel, Lecciones sobre filosofía de la historia universal (Madrid: Alianza, 1985), p. 104.

${ }^{262}$ Ibíd., pp. 103-104.

${ }^{263}$ Ibíd., p. 210.

${ }^{264}$ Efectivamente, el ser humano posee la capacidad de postergar sus impulsos mediante su propia voluntad. Y es a través de esta voluntad que los sujetos pueden organizarse bajo un orden político estatal y abandonar, así, su mera naturaleza.

${ }^{265}$ G. W. F. Hegel, Principios de la filosofía del derecho (Barcelona: Edhasa, 1999) p. 372.
} 
Aunque Kant representa su punto de partida inmediato, Hegel se distancia del mismo al considerar que la libertad no es algo puramente individual (o de lo contrario sería puro arbitrio). En la filosofía hegeliana, la libertad es una conquista realizada con los otros dentro de un proceso histórico, por lo que dicha libertad sólo alcanza su contenido concreto en "el nosotros", en las normas de la vida pública. Aquí, más que de Kant, Hegel se muestra heredero de Rousseau, pues éste consideraba que un pueblo es lo que son sus instituciones políticas (y las instituciones no son más que las costumbres de un pueblo, agregaría la filosofía hegeliana). Y esta identificación entre la ley y la libertad no es otra cosa que la eticidad.

Así, se puede decir que en la eticidad desaparece la oposición entre libertad individual y necesidad social, y el individuo se torna verdaderamente libre. Pero, como hemos mencionado, la eticidad sólo encontrará su más alta concreción en el Estado. ${ }^{266}$ Éste será el encargado de restablecer la eticidad, esto es, aquellas normas (prácticas e instituciones) de la vida pública que otorgan identidad al individuo como sujeto libre. De modo que $<<$ en el Estado alcanza la libertad su objetividad y vive en el goce de esta objetividad>>.267 Así pues, el Estado racional debe expresar las normas más altas reconocidas por los individuos como su propia identidad (como aquello que los hace ser, como su esencia).

Cabe señalar que el Estado sólo es considerado como algo racional en tanto se trata una institución fundada en la razón, en la actividad libre de los seres humanos, pero para continuar siendo racional ha de mostrarse a la altura de la razón en su momento histórico, ya que ésta va cambiando a través del tiempo; de lo contrario, el orden estatal se mostraría sólo como un momento en el desarrollo de la misma. Pero si bien el Estado emerge a través de las

$266<<$ El Estado es la realidad efectiva de la idea ética, el espíritu ético como voluntad sustancial revelada>>. G. W. F. Hegel, Principios de la filosofía del derecho (Barcelona: Edhasa, 1999), p. 370.

${ }^{267}$ G. W. F. Hegel, Lecciones sobre filosofía de la historia universal (Madrid: Alianza, 1985), pp. 103104. 
acciones humanas en la historia (pues no es sino el resultado de la libertad constituyéndose como tal), no ha surgido porque un individuo en particular o un grupo de ellos se lo hubiera propuesto; el orden estatal no pudo haber surgido de un plan individual ni grupal.

El Estado sólo se configuró en medio del decurso histórico. En la historia los sujetos no diseñaron el orden estatal y luego lo pusieron en práctica, por lo que en este sentido el Estado no fue configurado de acuerdo con un plan, sino que, de acuerdo con Hegel, surgió de la actividad del ser humano queriendo darse forma de libertad. De este modo, el Estado se ha configurado históricamente conforme a la libertad perseguida por la voluntad racional. Así, la razón se realiza a sí misma en el orden estatal, pero no lo hace a través de ciertos sujetos que formulan un ideal y, a partir del mismo, instituyen un Estado racional, tal como lo pretenden algunas doctrinas modernas.

De acuerdo con Hegel, en la Modernidad existe una tendencia a redactar nuevas constituciones en contraposición a la existente; no obstante, según nuestro autor, para redactar una constitución, no es suficiente el talento teórico del individuo, pues no son los individuos particulares los que hacen las constituciones, sino que ellos son el resultado de un proceso histórico. De modo que la formulación de una constitución no depende de la "especulación" individual de uno u otro sujeto, ni viene dada a priori por la mera razón, sino que depende enteramente de la vida espiritual de un pueblo en la historia (toda constitución encuentra su base en la vida espiritual de un pueblo). ${ }^{268}$ Es el pueblo el que, con base en su necesidad, ha de darse su constitución verdadera:

Así, pues, el pueblo histórico hace surgir siempre la verdadera constitución, la que cuadra a sus necesidades. Con el transcurso del

${ }^{268}$ De acuerdo con Hegel, la redacción de nuevas constituciones parece no tener dificultad para aquel individuo que se encuentra habituado a pensar formas posibles de constitución. Pero, según nuestro autor, frente a la potencia de la vida espiritual, los meros pensamientos del individuo no tiene más valor que el de la opinión; y si lo llegan a tener, es porque dichos pensamientos no son ya más que el producto mismo de aquella potencia universal. 
tiempo todo pueblo tiene que someter su constitución vigente a los cambios necesarios para ponerla cada vez más a tono con la verdadera. Su espíritu se descalza por sí mismo sus zapatos de niño; y la constitución es la consciencia de lo que ese espíritu es en sí, la forma de la verdad, del saber acerca de sí mismo. ${ }^{269}$

Las constituciones no permanecen tal y como son, sino que se transforman para alcanzar su verdad como manifestación viva del espíritu de un pueblo. Pero cuando el contenido de la constitución no es más verdad, esto es, cuando el concepto y su realidad son distintos, entonces el espíritu del pueblo se divide, se desgarra y sale de sus marcos. En el momento en que la constitución muestra al derecho que contiene como algo verdadero, pero no se muestra como tal ante la consciencia, entonces tal derecho deja de representar el espíritu del pueblo. Y cuando el derecho vigente, a pesar de que ha dejado de corresponder con la costumbre verdadera, se empecina en seguir rigiendo la vida del pueblo, entonces éste puede ir modificando paulatinamente tal derecho o puede romper con el mismo mediante una fuerza interna más potente. ${ }^{270}$

En este sentido, las instituciones desaparecen necesariamente; pero de cualquier modo, dice Hegel, nadie se resigna a perder sus derechos y busca la permanencia de ciertas instituciones. Así, el gobierno de un pueblo será el encargado de reformar el orden institucional para mantenerlo acorde con el espíritu del tiempo, el gobierno ha de saber cuándo las instituciones jurídicas se pierden y dan paso a otras (que por cierto han de contener a aquéllas); pero si, por el contrario, ignora lo que ahora es verdaderamente esencial y, con ello, se obstina en mantener lo temporal (es decir, las instituciones ya obsoletas),

${ }^{269}$ G. W. F. Hegel, Lecciones sobre historia de la filosofía II (México: FCE, 1955), p. 220.

${ }^{270}$ Pero, de acuerdo con nuestro autor, si el pueblo no cuenta con la fuerza ni con la inteligencia indispensables para transformar el derecho y, por ello, se sigue rigiendo bajo este derecho ya obsoleto, entonces sucumbirá ante otro pueblo que, en tanto ha logrado actualizar su derecho, se erige como superior. 
entonces habrá un día en el que tal gobierno sucumbirá frente al incontenible desarrollo del espíritu del pueblo. ${ }^{271}$

De este modo, aquello que se opone a la constitución verdadera carece de consistencia alguna, tiene sólo una existencia temporal, efímera. En tanto carece de verdad, no puede mantenerse por mucho tiempo, no puede contar con una larga vida. Si bien el derecho vigente ha regido por un tiempo, la idea misma de constitución contiene la exigencia de que, cuando llegue su tiempo, tal derecho sea derogado (abolido): $<<Y$ a esta consciencia sólo puede llegarse por el camino de la filosofía. Las transformaciones del Estado se operan sin revoluciones violentas, cuando la consciencia es general >>.272 La filosofía permite tomar consciencia de que el orden estatal ha de ser transformado cuando no corresponda más con el momento espiritual que se vive, esto es, con las costumbres del pueblo en un momento histórico determinado.

De esta manera, se verá que cuando la constitución es considerada abstractamente, independiente de toda determinación espacio-temporal, no contiene nada en sí misma, salvo principios igualmente abstractos; pero, por el contrario, cuando es pensada concretamente se observará que no constituye sino las costumbres de un pueblo puestas en leyes. De ahí que una constitución viva ha de referirse a las costumbres del pueblo que se rige bajo ella y, en consecuencia, ha de esforzarse incesantemente por plasmar el espíritu vivo del mismo. De acuerdo con Hegel, la vida pública del Estado sólo se mantiene en virtud de las costumbres, y las costumbres, a su vez, sólo se mantienen en virtud de las instituciones estatales. Las instituciones cobran una existencia efectiva a través de las costumbres, las cuales no surgen, de hecho, sino de las instituciones (en este sentido, como ya se ha dicho, Hegel coincidirá con Rousseau al considerar que un pueblo no es sino lo que son sus instituciones,

\footnotetext{
${ }^{271} \mathrm{Si}$ el aparato gubernamental, en lugar de acoger lo esencial - lo cual se encuentra implícito en la Idea, en lo realmente verdadero-, mantiene aquello que rige de modo inesencial, entonces el gobierno se desintegrará, y así también lo hará el propio pueblo. Con la disolución del gobierno vigente emerge uno nuevo o, en su caso, se mantiene el antiguo aparato gubernamental e impone entonces lo inesencial.

${ }^{272}$ Loc. cit.
} 
pero irá más lejos al decir que las instituciones no son más que las costumbres de un pueblo; donde lo único verdadero es el proceso en el que ambas, costumbres e instituciones, se constituyen recíprocamente como tales).

Es de esta forma que nuestro autor nos lleva a la consideración de que el Estado sólo se realiza paulatinamente con el tiempo y lo hace sólo bajo una determinada vida espiritual; pero en tanto la vida espiritual de un pueblo, es decir, sus costumbres hechas institución son las que constituyen las condiciones específicas por las que surge un cierto Estado, y no otro, se sigue que bajo otras condiciones muy distintas no puede ponerse en marcha el mismo orden estatal ni, por tanto, la misma constitución: <<Una constitución perfecta - dice Hegel - debe considerarse siempre en relación con un pueblo dado, sin perder de vista que una constitución, por perfecta que sea, no puede ser conveniente para todo pueblo>>.273 Hegel se opone así a la formulación de un orden ideal perfecto que sería válido en todo tiempo y en todo lugar, ya que tal formulación pasaría por alto el hecho de que sólo el pueblo puede darse su propia constitución, ya que una constitución venida desde fuera no le podría corresponder en ningún sentido; esto debido a que las condiciones específicas en las que se halla tanto histórica como territorialmente sólo pueden dar lugar a un cierto orden constitucional y a una cierta forma de Estado, y no otra.

De tal suerte que, aun si los sujetos fueran capaces de adelantarse a su propio tiempo y formularan la vía para acceder a un Estado idealmente racional, éste no se podría implementar, ya que ello exigiría que los sujetos se identificaran con una forma de vida espiritual que aún no habrían alcanzado, lo cual es prácticamente imposible. De este modo, según Hegel, no resulta plausible implementar un determinado orden estatal, por racional que éste pueda parecer, en cualquier tiempo y en cualquier lugar; pues la vida espiritual por la que los miembros de un pueblo viven y en la que se identifican sería

\footnotetext{
${ }^{273}$ Ibíd., p. 219.
} 
inconmensurable con aquel orden que se pretende implantar. ${ }^{274}$ La Idea de un Estado formulado subjetivamente sólo en las mientes del filósofo, no puede ser aplicado a una determinada realidad si en ella no existen las condiciones objetivas necesarias para tal aplicación. Pero, además, a pesar de que pudieran existir las condiciones propicias para la implementación de una cierta Idea de Estado, el establecimiento del mismo fracasaría, ya que tal Idea, al no ser producto de la vida espiritual de los ciudadanos, éstos no se identificarían con un tal Estado. 275

De esta manera, toda doctrina que se enfoca en la mera formulación de un Estado idealmente racional, en tanto no atiende por definición a las condiciones objetivas de su presente, está pretendiendo trascender su propio tiempo, lo cual significa que pretende saltar por encima de su vida espiritual misma. Pero, de acuerdo con Hegel, resulta insensato que la filosofía pueda ir más allá de su propio tiempo, pues ella consiste, no en formular un Estado idealmente racional que se encuentre más allá del tiempo presente, sino en tratar de aprehenderle a través del pensamiento. En este sentido, todo individuo que en filosofía pretenda formular un Estado tal como debe ser, estaría tratando de escapar vanamente a su momento histórico, estaría esperando saltar por encima de su época, lo cual resulta absurdo, ya que cada individuo no es hijo sino de su propio tiempo.

No es que el individuo no pueda formular una teoría de cómo deba ser el orden estatal, pero con ello no estaría sino proyectando su propia subjetividad en el mundo, por lo que su deber ser carecería de verdadera objetividad: $<<\mathrm{El}$ mundo se ve según como se le considere. Si nos acercamos al mundo sólo con nuestra subjetividad, lo encontraremos tal como nosotros mismos estamos constituidos; sabremos y veremos cómo ha tenido que hacerse todo y cómo

\footnotetext{
${ }^{274}$ Aun si alguien ubicado en el presente fuera capaz de mostrar retrospectivamente el Estado a algunos sujetos ubicados en el pasado, éstos se mostrarían incapaces de realizarlo, pues dichos sujetos, sumergidos en su propia vida espiritual, no serían capaces de identificarse con tal Estado.

${ }_{275}^{2}$ La mera formulación de un Estado ideal, pues, no permitiría la identificación de los sujetos reales (que tienen como fundamento la historia) con dicho Estado.
} 
hubiera debido ser>>.276 De modo que si el individuo logra formular una teoría que determine cómo debe ser el orden estatal, dicho orden se mostrará tal como se le aparece el mundo subjetivamente, y en tal caso otro individuo podría idear, con el mismo derecho, otro orden estatal igualmente válido. Así, todo individuo se halla inevitablemente inserto en su tiempo, el cual lo constituye como tal y, por tanto, es lo único que le puede llevar a formular una cierta idea de cómo ha de ser el mundo.

No obstante, para Hegel la filosofía ha de tratar de concebir su propio tiempo de forma objetiva para reconciliarse con su presente. De acuerdo con nuestro autor, <<nadie puede saltar por encima de su tiempo; el espíritu de su tiempo es también su espíritu; pero de lo que se trata es de reconocerlo con arreglo a su contenido $>>.{ }^{277}$ La filosofía ha de reconocer, entonces, el espíritu de su tiempo desde su propio presente, y no desde la Idea de un Estado racional que se encuentre más allá del mismo dictando cómo debe ser la realidad, tal como lo busca la doctrina normativa. Empero, vale decir que esta caracterización de la filosofía como una reflexión puramente normativa tiene su origen preciso a inicios de la Modernidad, justo donde la subjetividad es ponderada sobre cualquier otro principio.

Efectivamente, de acuerdo con Hegel, el afrontar el problema de pensar la racionalidad del orden estatal formulando un Estado ideal, pertenece a una idea de la Modernidad. En el mundo moderno, el orden estatal real es regularmente dejado de lado en nombre del Estado idealmente racional en el que, según esto, existiría una plena libertad. ${ }^{278}$ Ciertamente, en la época moderna el ser humano adquiere una elevada consciencia de su subjetividad y busca hallar el fundamento tanto de su libertad como de su vida ética en el

${ }^{276}$ G. W. F. Hegel, Lecciones sobre filosofía de la historia universal (Madrid: Alianza, 1989), p. 45.

${ }^{277}$ G. W. F. Hegel, Lecciones sobre historia de la filosofía II (México: FCE, 1955), p. 219

278 <<La representación — dice Hegel- según la cual la libertad del pensamiento y del espíritu se demuestra exclusivamente con el alejamiento e incluso la hostilidad a lo reconocido públicamente, ha logrado su mayor arraigo en nuestro tiempo en relación con el Estado >. G.W. F. Hegel, Principios de la filosofía del derecho (Barcelona: Edhasa, 1999), pp. 49-50. 
pensamiento mismo; el problema surge cuando abstrae el pensamiento de lo concreto y, ensimismándose, cree alcanzar su libertad apartándose de la validez universal, de lo que es públicamente reconocido, y termina por colocar su particularidad como lo únicamente válido. Pero al elevar su pura subjetividad a lo universal, cae en la injusticia: <<el hombre piensa y busca en el pensamiento su libertad y el fundamento de la eticidad. Este derecho, tan elevado y divino como es, se transforma sin embargo en injusticia cuando el pensamiento sólo se considera tal y sólo se sabe libre en la medida en que se aleja de lo universalmente reconocido y válido y se inventa algo particular $>>.279$

Así, para Hegel, en la filosofía moderna cualquiera se siente facultado para hablar, desde su mero punto de vista subjetivo, sobre la forma del Estado; y a partir de esta pura subjetividad es como se pretende fundar la vida ética en general. Es así que en los tiempos modernos se tiende a considerar a la filosofía política como una actividad reflexiva que sólo se ocupa de elaborar mundos ideales para contraponerlos al real. Empero, $<<$ de acuerdo con esta representación, una filosofía acerca del Estado parecería tener extrañamente como tarea esencial producir e inventar otra teoría, por supuesto nueva y particular $>.280$ Pero si esto fuera así, si una filosofía que se ocupa del Estado tuviera la única función de idear una nueva forma de orden estatal, entonces se tendría que admitir que jamás ha existido Estado alguno en el mundo, pues aquello que consideramos como orden estatal en la actualidad no correspondería con la Idea del Estado racional que la filosofía normativa promueve. ${ }^{281}$ En este respecto, la filosofía se comporta como si el mundo político hubiese tenido que esperarle para ser pensado, e incluso vivido.

${ }^{279}$ Ibíd., p. 49.

${ }^{280}$ Ibíd., p. 50.

${ }^{281}$ De acuerdo con esto, cada vez que se tuviera una nueva teoría sobre el Estado se tendría que dar comienzo nuevamente a la institución del orden estatal desde el inicio; sin embargo, este comienzo se tendría que dar indefinidamente, pues de acuerdo con la Idea racional del Estado, lo que hoy consideramos como orden estatal no sería estrictamente un Estado, pues no es como realmente debe ser. 
Pero de acuerdo con Hegel, el orden estatal no ha tenido que esperar ninguna doctrina filosófica para andar y abrirse paso en la historia. Así, Hegel no comparte la idea normativa de diseñar un Estado racional para ulteriormente ponerlo en práctica, pues ello impide pensar la racionalidad efectiva del orden estatal existente. No obstante, cabe aquí poner énfasis en una idea que ya se ha señalado, pero que, sin embargo, frecuentemente parece ignorarse, y es que todo teórico normativista está situado en un cierto momento histórico del que le es imposible escapar, y en el momento en el que encuentra una inconformidad con la situación que le rodea, concluye que el mundo no es como debería ser, por lo que se inclina a formular un mundo ideal que le permita criticar el actual. Sin embargo, tal formulación se ve condicionada justo por la etapa histórica en la que se encuentra. En realidad el propio deber ser sólo puede surgir del ser, del mundo real.

De modo que, son precisamente aquellas condiciones históricas las que le hacen plantear al teórico un cierto deber ser, ellas son las que indican cómo debe ser el mundo. De tal suerte que cuando las condiciones cambien, se habrá de formular otro deber ser que concuerde con las nuevas circunstancias, pues éstas mostrarán al anterior como algo ya obsoleto. Y así, cada vez que el proceso histórico devenga en otras condiciones, el deber ser tendrá que ser reformulado conforme a las mismas para que no se torne algo obsoleto. Será la misma realidad histórica la que siempre marcará la pauta para formular un nuevo deber ser; que, por cierto, nunca podrá ser realizado, pues cuando trate de ponerse en práctica, la realidad habrá ya tomado otro rumbo, y ese deber ser desaparecerá como deber (dejará de constituir como tal un deber para el ser humano). Dependiendo de las circunstancias en las que se encuentren los seres humanos se formulará un cierto deber ser, por lo que cuando ellas cambien exigirán la formulación de otro.

En el ámbito moral y político, Hegel critica por varias razones esta idea de un deber ser, pero con dicha crítica se está enfrentando sobre todo al 
subjetivismo moderno (que pretende fundar la vida en común en la mera representación del sujeto). Nuestro autor piensa que el problema de ello es que la consciencia subjetiva, con base en la nostalgia y la esperanza, mira más allá de la realidad presente, a la que concibe como un sinsentido y en la que se siente fuera de casa, y se enfoca en decir cómo debería ser el mundo.

Así, con respecto al orden político, esta consciencia subjetiva apoya su juicio en el sentimiento, el amor, el bien, la amistad... con lo que al basarse en los meros dictados del corazón, muestra un cierto desdén hacia la razón. De modo que partiendo de la mera subjetividad para fundar la vida política, esta consciencia individual cae en la arbitrariedad, en el capricho, y termina en cierto sentido por abandonar la razón. Pero con ello la realidad no se le presenta sino como un puro desorden, con lo que suele pensar a la vida ética como un mundo "abandonado a la contingencia y a la arbitrariedad, abandonado de Dios". No piensa al mundo ético sino abandonado "a la contingencia subjetiva de la opinión y del arbitrio".

Esta conciencia individual sostiene que todo sentido no emana más que de la subjetividad (del corazón, del sentimiento y el entusiasmo), y que no es posible alcanzar una verdadera objetividad. Pero todo ello ha llevado, según Hegel, a "un descredito y desprecio general" por la filosofía. Y existen quienes, además de despreciar a la filosofía, se dirigen contra ella al considerar que su contenido, esto es, el conocimiento de la verdad, constituye "una presunción insensata y pecaminosa"; con lo que "la razón es acusada, rebajada y condenada". Pero, de acuerdo con nuestro autor, esto no hace sino mostrar lo incómodo que resultan, para aquellas doctrinas que dicen buscar el conocimiento, las pretensiones de la filosofía especulativa.

La pretensión de la filosofía hegeliana no es otra que la de poner a la razón como el principio rector del mundo, lo que en el ámbito práctico se ha de traducir como la realización de la voluntad libre en el orden estatal. En el 
ámbito práctico, Hegel confía a la razón la tarea de llevar a los seres humanos a una vida política más alta; en donde no sea más que la razón la que, apropiándose del mundo y de sí misma a través de una incesante transformación, se coloque en el presente para pensarlo en su efectividad.

Hegel piensa que la filosofía política debe plantearse, no la elaboración de modelos prescriptivos, sino la aprehensión de la realidad presente para pensarla en su verdad: <<la filosofía, por ser la investigación de lo racional, consiste en la captación de lo presente y lo real, y no en la posición de un más allá que sabe Dios dónde tendría que estar, aunque en realidad bien puede decirse dónde está: en el error de un razonamiento vacío y unilateral>>.282 Así, la filosofía debe pensar racionalmente la realidad, ya que ésta no es en ningún sentido algo ajeno a la razón, sino que es la razón misma hecha mundo. De ahí que la filosofía no ha de sumergirse en el ensueño de un deber ser que se encuentre más allá de lo efectivamente real, pues tal deber no puede tener más asiento que el pensamiento puramente subjetivo y abstracto.

Hegel considera que esta "captación" de la realidad presente es plausible debido a que la filosofía muestra que todo $<<[\ldots]$ lo que es real es racional $>>283$, lo cual significa que no hay realidad independiente del pensamiento (es un hecho que la realidad existe fuera del pensar, pero aunque pueda ser considerada como una realidad en sí, si no es determinada por el pensamiento equivale a la nada; si no existiera más que el mundo, no habría de hecho mundo, pues éste sólo es porque es pensado). Ahora bien, Hegel afirma también que todo $<<$ lo que es racional es real [...] $>>284$, lo cual denota que no puede haber pensamiento independiente de la realidad (aquí también es un hecho que el pensamiento existe, pero a pesar de que éste pueda ser tenido como un pensamiento puro, sin un mundo que pensar equivale igualmente a la nada; si

\footnotetext{
${ }^{282}$ Ibid., p. 58.

${ }^{283}$ Ibíd., p. 59.

${ }^{284}$ Loc. cit.
} 
no hubiera más que ideas, no habría de hecho ideas, porque la idea es sólo aquello que se encuentra en la realidad).

De este modo, para nuestro autor, a diferencia de otros pensadores, lo racional se realiza efectivamente en el mundo (o mejor dicho, la razón se realiza como mundo real), por lo que como señala en distintas ocasiones "la razón rige el mundo": La razón es <<sustancia, como aquello por lo cual y en lo cual toda realidad tiene su ser y consistencia; potencia infinita, porque la razón no es tan impotente que sólo alcance al ideal, a lo que debe ser, y sólo exista fuera de la realidad, quién sabe dónde, quizá como algo particular en las cabezas de algunos hombres $>>.285$ Lo racional no es algo que se quede en una mera Idea, que sólo se encuentre en la mente de ciertos individuos que luego la postulen como un simple deber ser carente de realidad; sino que la Idea misma es lo efectivamente racional, por lo que ha de ser entendida como algo siempre puesto en práctica. En este sentido, se puede decir que $<<$ la filosofía opera también a priori, puesto que supone la Idea. Pero esta existe ciertamente; tal es la convicción de la razón>>.286 A diferencia de doctrinas como la kantiana, la filosofía hegeliana considera que la Idea se halla efectivamente presente en la realidad, lo cual denota que en dicha filosofía no hay una separación entre lo real y lo ideal, entre el pensamiento y la realidad.

Así pues, en la metafísica hegeliana no hay por un lado un pensamiento (con ideas puras) y por otro una realidad (de objetos dados), sino una unidad. Nuestro autor no parte de una razón acabada ni de una realidad dada, pues no hay realidad anterior al pensamiento y no hay pensamiento anterior a la realidad, ambos se constituyen en un mismo y único proceso, por lo que no pueden ser considerados como datos, sino como resultados.

En este sentido, vale repetir aquí una precisión que resulta fundamental para nuestra investigación. Dicha precisión es la siguiente: en las proposiciones

\footnotetext{
${ }^{285}$ G. W. F. Hegel, Lecciones sobre filosofía de la historia universal (Madrid: Alianza, 1989), p. 43.

${ }^{286}$ Ibíd., p. 46.
} 
"todo lo racional es real" y "todo lo real es racional", lo "real" no debe identificarse con la realidad sin más (Realität), ya que con aquel término Hegel no se está refiriendo a lo simplemente real, sino a lo "efectivamente real" ${ }^{287}$ Aquí la categoría de efectividad (Wirklichkeit)288 denota la realidad íntegramente pensada (la unidad entre realidad y pensamiento), refiere a la actividad de la reflexión reconociendo el proceso que explica la realidad tal como aparece. Es a través de la reconstrucción reflexiva de lo real que el pensamiento muestra el proceso que trajo a eso mismo real a la existencia. Al dar cuenta de lo real tal como es en el presente, el pensamiento establece su racionalidad, encuentra su razón de ser.

Así, lo real, entendido como algo completamente racional, es entonces el resultado de un proceso, lo cual implica, a su vez, que toda realidad fundada en la razón se constituye en el tiempo, es decir, tiene una determinación esencialmente histórica; por lo que no hay una oposición entre razón e historia, sino una unidad indisoluble: no hay historia sin razón y no hay razón sin historia 289 (en otras palabras, el ser humano hace la historia y la historia hace al ser humano). En consecuencia, se puede afirmar que la historia no es sino la obra del ser humano y su razón: <<La razón ve, en lo que nace y perece, la obra que ha brotado del trabajo universal del género humano, una obra que existe realmente en el mundo a que nosotros pertenecemos $>>.{ }^{290}$ En tanto la historia no es más que la marcha de la razón, puede entonces ser concebida racionalmente. A través de la reconstitución objetiva de la realidad histórica

${ }^{287}$ Cfr., G. W. F. Hegel, Enciclopedia de las ciencias filosóficas (Madrid: Alianza, 1999), p. 106.

${ }^{288}$ Wirklichkeit (efectividad) encierra las ideas tanto de realidad como de actividad, pues se relaciona con el verbo Verwirklichen (realizar). De ahí que la efectividad sea considerada como la realización progresiva de la realidad objetiva.

${ }^{289}$ La razón es histórica, o sea, la razón se desenvuelve en la historia; y la historia es racional, esto es, la historia es el desenvolvimiento de la razón.

${ }^{290}$ G. W. F. Hegel, Lecciones sobre filosofía de la historia universal (Madrid: Alianza, 1989), p. 57. 
por medio de la razón, le es posible al ser humano acceder al conocimiento racional de su presente. ${ }^{291}$

De este modo, el pensamiento puede concebir la racionalidad de lo real, eso que por cierto muchos quieren ver como irracional, y que precisamente por ello formulan cómo debe ser aquella realidad que pretenda ser racional. Ciertamente, a primera vista lo real se le presenta al pensamiento inmediato como algo absurdo; pero, de acuerdo con Hegel, $<<$ lo verdadero no se halla en la superficie visible. Singularmente en lo que debe ser científico, la razón no puede dormir y es menester emplear la reflexión. Quien mira racionalmente el mundo, lo ve racional. Ambas cosas se determinan mutuamente >>.292 De modo que, si el pensamiento, con base en la mera subjetividad, considera al presente como algo vano, entonces él mismo será algo vano, pues el propio pensamiento sólo podría adquirir existencia en ese vano presente. Por un lado, si la consciencia va más allá del presente y cree saber más que él, entonces lo considera como algo banal; pero, por otro lado, en tanto la consciencia no puede ir más allá y no puede saber más que sobre su propio presente, ella misma es banal, pues considera su fundamento, esto es, su presente, como algo vano sin más.

En este sentido, oponiéndose a aquellos que, dirigiéndose con una mirada irracional, no pueden ver sino desorden en el mundo, Hegel trata de mostrar la racionalidad contenida en el mismo. De acuerdo con nuestro autor, si se pretende ver racionalmente al mundo, se tiene que dirigir una mirada racional hacia él: < <Para conocer lo sustancial - dice Hegel- hay que acercarse a ello con la razón>>.293 Únicamente cuando el pensamiento se acerca con la razón al mundo, puede comprender racionalmente aquello que ya desde siempre ha estado en proceso: el presente.

${ }^{291}$ De acuerdo con Hegel, conocer no consiste en re-presentar un objeto dado, sino en reconstruirlo en su plenitud a través de un proceso racional; proceso en el que el pensamiento transforma la realidad y, con ello, se transforma a sí mismo. De modo que, conocer un objeto no es representarlo, sino transformarlo.

${ }^{292}$ Ibíd., p. 45.

${ }^{293}$ Loc. cit. 
Pero cabe señalar que el pensamiento únicamente puede concebir racionalmente aquello que la razón misma ha ya realizado en la historia, aquello que ha alcanzado hasta su presente. La razón crea la historia, y sólo después la comprende conceptualmente: $<<$ Lo que enseña el concepto lo muestra con la misma necesidad la historia: sólo en la madurez de la realidad aparece lo ideal frente a lo real y erige a este mismo mundo, aprehendido en su sustancia, en la figura de un reino intelectual >>.294 En términos políticos esto significa que el Estado realmente racional, como realización de la razón en su propio despliegue, no puede ser plenamente concebido hasta que entre en la existencia. No es que no se pueda pensar un Estado ideal, pero éste sólo será concebido de acuerdo a la propia subjetividad del teórico. ${ }^{295}$ Es sólo la presencia del Estado real lo que permite concebirlo mediante las ideas, y sólo las ideas permiten hacerlo objetivamente inteligible (además cabe destacar que en el desarrollo mismo de la razón, los momentos más altos del proceso no pueden ser comprendidos por los momentos anteriores del mismo; por el contrario, es la clave del presente la que otorga la clave del pasado).

Las transformaciones históricas de lo real pueden ser comprendidas sólo después de que han acaecido, pues antes de que tengan lugar son meras posibilidades. Sólo una vez que se han presentado los hechos, el pensamiento, a través de una plena reconstitución reflexiva, puede concebir su racionalidad. No obstante, cabe señalar que la mera determinación histórica de la realidad, no garantiza su racionalidad efectiva; ya que si determinado objeto no puede ser reconstruido en un todo coherente, esto es, en una trama de categorías donde una remita a la otra necesariamente, sin duda existe, pero no puede ser considerado realidad efectivamente racional (es decir, realidad efectiva).

${ }^{294}$ G.W. F. Hegel, Principios de la filosofía del derecho (Barcelona: Edhasa, 1999), p. 63 [El subrayado es propio].

295 Antes de que se realizara el Estado en la historia, éste resultaba completamente inconcebible (equivaldría a pretender concebir un descubrimiento todavía no descubierto), pero una vez que apareció en el tiempo se hizo posible pensarle de diferentes formas, lo cual también se aprovechó para idealizarlo a partir de las esperanzas propias. 
Así, el que la razón se realice en la historia ${ }^{296}$, no significa que la realidad sea plenamente racional sin más, pues en ella también hay sinrazón. En efecto, la razón se realiza en una serie de momentos, los cuales se desarrollan, a nuestros ojos, de menor a mayor perfección (esto es, en orden a un progreso). De ahí que, desde la perspectiva de momentos ulteriores, los primeros momentos se muestran como una realización imperfecta de la razón. $\mathrm{Y}$ en tanto estos momentos en su conjunto no son sino el desenvolvimiento de la razón, siguen una necesidad, en la que cada momento de imperfección que la razón ha alcanzado es él mismo, en el momento de su llegada, conforme a la razón. ${ }^{297}$ Así, el grado de realización de la razón en determinado momento no es sino obra de la misma razón tratando de reencontrarse consigo. Únicamente desde nuestro presente podemos decir que lo real en otros momentos es lo no completamente racional (pero, como se puede ver, esto constituye ya una crítica inmanente de la propia razón).

En este sentido, en el ámbito político la mera historicidad del orden estatal no garantiza su plena racionalidad. El que determinado orden político se presente tal y como es, con lo que tiene de contingente y de necesario, no muestra sino el grado de racionalidad que han alcanzado los seres humanos en su historia (ellos deben reconocer que este orden político, tal como aparece, no es más que su obra; y en tanto obra suya, denota el nivel de progreso de su propia época). Empero, la simple presencia del orden político es por lo demás indicio de que la razón se está ya realizando en la historia. Y aunque no pueda ser considerado del todo racional, este orden político, tal como se presenta, contiene ya las condiciones de su propia transformación; condiciones que permiten a la razón establecer el sentido mismo de dicha transformación, cuya

\footnotetext{
${ }^{296}$ La historia muestra que la razón no se configura sino a través del tiempo; pero en tanto la razón se realiza a sí misma en su propio devenir, la historia no es más que la autoconfiguración de la razón.

${ }^{297}$ En el momento en el que la libertad cobra su realización, verbigracia, constituye ya el germen de su propia superación, se da siempre un momento de perfección (perfecta realización), llena de imperfección (realización imperfecta). Aquello que se ha logrado será premisa de aquello que esto mismo arroje como resultado, y lo contendrá como algo subsumido.
} 
efectuación constituiría por cierto la realización de las más elevadas exigencias espirituales del momento histórico.

Sin embargo, la identificación de aquellas condiciones que anuncian ya la transformación del orden político, únicamente puede venir dada por la reconstrucción misma de dicho orden. ${ }^{298}$ Es a través del proceso que trata de concebir el orden político que se puede hallar el germen de su transformación. En el momento en el que reflexión alcanza la plena reconstrucción racional del orden político presente a través de sus determinaciones esenciales, entonces éste se muestra como necesario, pero también muestra su propio declive. Pensar el presente es, pues, reconstruir el proceso que lo explica, que explica su necesidad, su razón de ser y que al mismo tiempo descubre su porvenir. ${ }^{299}$

Pero no nos equivoquemos, la filosofía no puede conocer nada de antemano, por lo que pensar el presente no es adivinar qué será en el futuro, sino es hallar en él la presencia del pasado, puesto que lo único estrictamente necesario es lo pasado: <<cuando la filosofía pinta con sus tonos grises, ya ha envejecido una figura de la vida que sus penumbras no pueden rejuvenecer, sino sólo conocer >>.300 Es en este sentido que <<el búho de Minerva —advierte Hegel— sólo alza su vuelo en el ocaso $>>{ }^{301}$ De cualquier modo, esto no impide pensar que, como se dice en la Lógica, cuando se cumplen todas las condiciones necesarias para que algo se dé a la existencia, entonces el saber científico anuncia que ese algo se dará necesariamente, o mejor dicho (y para evitar toda interpretación precipitada), ya se está dando de alguna forma en lo efectivo.

Es justo en este respecto que la categoría de realidad efectiva se ve encomendada a pensar la necesidad del presente para que, a través de su reconstrucción, éste mismo ofrezca la pauta para su transformación. Es con la

\footnotetext{
${ }^{298}$ Reconstrucción mediante la que Hegel pretende concebir al presente en su verdad (en este sentido busca volver a la unión originaria entre ciencia y filosofía).

${ }^{299}$ Se trata de un tema bastante complejo y discutido, por lo que no lo desarrollaremos aquí, pero que sin duda resulta esencial a la filosofía política de Hegel.

${ }^{300}$ Loc. cit.

${ }^{301}$ Loc. cit.
} 
categoría de realidad efectiva que nuestro autor busca una aprehensión de la realidad que permita identificar qué hay de absurdo en el presente para transformarlo de acuerdo con aquello que la razón ha reconocido como justo. Son las propias exigencias de la razón las que plantean la necesidad de transformación del presente (exigencias que son también las exigencias del momento histórico, pues la razón se ubica siempre en una determinada etapa de la historia, la cual la configura de una cierta manera). Bajo esta concepción, la categoría de realidad efectiva trae consecuencias revolucionarias en cuanto a la forma de entender la crítica en el ámbito político.

Aunque Hegel coincide con Kant, y otros, en que la filosofía política ha de mantener un carácter crítico ante la realidad, diverge en tanto piensa que que no por ello se debe distinguir tajantemente entre el ser y el deber ser (ni contraponerlos). Nuestro autor trata de ver en el ser ya la realización de lo que los seres humanos con sus actos consideran lo que deber ser el mundo. Sin embargo, no se trata aquí de una variante de la falacia naturalista (lo que es, es lo que debe ser), ya que si Hegel identificara plenamente el ser con el deber ser - tratando de acabar por completo con su diferencia - estaría consagrando al mundo existente; con lo cual la actividad política carecería de sentido, pues ésta es considerada justamente como una actividad para la transformación del mundo presente.

Si bien es cierto que lo que es, no es en cierta manera lo que debe ser y si, en virtud de ello, la realidad se debe transformar, Hegel piensa que dicha transformación debe ser paulatina y sin la necesidad de postular un ideal inalcanzable donde se ubicaría lo verdaderamente racional. Nuestro filósofo piensa que el mundo es ya racional, por lo que no encuentra mucho sentido en planear un mundo tal como debería de ser e intentar llevarlo a la práctica conforme lo desea la mera razón subjetiva (además, como hemos visto, planear un mundo tal equivaldría a pretender anticiparse a la propia realización de la razón, donde al ser todo válido, se abandona la objetividad). 
De acuerdo con Hegel, los seres humanos están ya transformando al mundo con su actividad sin la necesidad de que el filósofo plantee un ideal a seguir, e incluso lo hacen sin siquiera ocuparse de que dichas transformaciones coincidan o no con las idealizaciones de filosofía alguna. En este sentido, la filosofía política no tiene por qué ocuparse de la formulación de ideales, entendidos como algo puramente abstracto, ya que $<<$ la tarea de la filosofía afirma Hegel - es concebir lo que es, pues lo que es es la razón>>.302 Empero, como ya se ha dicho, el que lo real sea racional no quiere decir que el mundo que habitamos sea el mejor de los mundos posibles, aunque sin duda es el mundo que hemos creado con nuestros actos acompañados de la razón.

Hegel piensa que si se puede mostrar que lo real es ya racional, no hay por qué postular un ideal a seguir, pues ello supondría que, por un lado, se encuentra una ciega realidad que necesitaría ser dotada de sentido por un pensamiento que, por otro lado, se encontraría recluido en sí mismo. Todo lo cual resulta contradictorio, pues ¿qué sería el pensamiento sin la realidad, y qué sería la realidad sin el pensamiento? De este modo, razón y realidad se hallan unidas. Sin embargo, al sostener que lo real es racional, Hegel ha sido tildado de conservador, pues con ello, de acuerdo con sus opositores, estaría santificando al mundo y tratando de mantener el orden establecido. No obstante, el que lo efectivo sea racional simplemente significa que el pensamiento puede pensar la razón de ser del presente, pues tal presente no es sino la realización de la propia razón en su libre autodeterminación. ${ }^{303}$

Se trata de reconocer la razón en el mundo presente, sin por ello negar que una parte (tal vez significativa) del mismo sea absurda, y que es de hecho la que se nos muestra a primera vista: $<<$ de lo que se trata, entonces, es de reconocer en la apariencia de lo temporal y pasajero la sustancia, que es

\footnotetext{
${ }^{302}$ Ibíd., p. 61.

${ }^{303}$ Como hemos visto anteriormente, los seres humanos crean al mundo con su actividad guiada por la razón, y al crearlo lo dotan de necesidad — esto es, lo hacen ser como es-, y al hacerlo se autodeterminan como seres libres; no hay entonces oposición entre libertad y necesidad, pues los individuos crean libremente su propia necesidad.
} 
inmanente, y lo eterno, que es presente >>.304 Aunque en una primera instancia el mundo se nos aparece como algo que pasará con el tiempo y, por tanto, como algo carente de fundamento, Hegel nos pide reconocer que la razón es inmanente al mundo y que incluso constituye su propia sustancia; por lo que el presente no es algo que simplemente pasará, sino que se mantiene en el tiempo como proceso, esto es, como algo que constantemente está cambiando en su propia permanencia: el presente siempre subsume su pasado, por lo que dicho presente no es sino el pasado que se ha superado a sí mismo (el presente no cancela el pasado, sino que lo conserva subsumido).

$\mathrm{Al}$ reconocer que la realidad es ya racional, Hegel no está tratando de justificar el orden establecido, sino que está reclamando a los teóricos del normativismo su persistencia en fundar al Estado en una Idea, la cual se encontraría más allá del mundo presente, ignorando que la razón se encuentra ya en el Estado real, pues no es sino la razón la que lo ha fundado. Nuestro autor dirige su crítica contra quienes guardan la esperanza de instituir otro orden social ignorando la racionalidad del actual, el cual está ya transformándose conforme a las exigencias mismas de la razón sin la necesidad de formular un ideal.

De acuerdo con Hegel, mientras que una filosofía a medias se aparta del Estado real y busca una formulación ideal del mismo, la verdadera filosofía, en cambio, conduce al propio Estado real considerándolo como algo racional. Mientras la filosofía verdadera logra aprehender conceptualmente al orden estatal en su presente, la filosofía a medias se complace con un mero acercamiento al Estado verdadero. Pero, <<así como la razón no se contenta con el acercamiento [...] tampoco se contenta con la fría desesperación que admite que en esta temporalidad todo anda mal o, a lo sumo, mediocremente, pero que afirma que en ella no se puede tener nada mejor y que sólo por ello hay que estar en paz con la realidad; es una paz más cálida la que proporciona el

\footnotetext{
${ }^{304}$ Ibíd., p. 59.
} 
conocimiento>>.305 Para Hegel, la razón no se complace en conceder que el mundo es de por sí algo imperfecto que no admite transformación alguna y que, por ello, habría que ser aceptado tal como es. Por el contrario, nuestro autor piensa que el mundo es perfectible por la actividad de la razón y que el conocimiento del mismo nos puede llevar a una reconciliación con el presente. En este sentido, contrariamente al discurso normativista, piensa que la razón no se complace con una mera aproximación a la Idea, sino que pretende mostrarla como algo ya realizado.

De ahí que con su filosofía, Hegel no criticaría directamente la pretensión de aproximarse a una cierta Idea de Estado, sino la formulación misma de la Idea, ya que ésta habría surgido de la separación entre ser y pensar, sería obra del pensamiento subjetivo y, por tanto, representaría sólo una Idea posible dentro de otras posibles (al respecto Hegel no reprocharía a los normativistas el no pretender encontrar una conexión entre el nivel descriptivo del ser y el nivel prescriptivo del deber ser, sino el hecho de haberlos separado tajantemente cuando en un principio deberían de ir unidos). Así, con su categoría de realidad efectiva Hegel estaría tomando distancia de toda la tradición normativista al plantear que para juzgar el presente no es necesario formular un nivel puramente prescriptivo y, con ello, abandonar el nivel descriptivo, sino que es desde el presente mismo desde donde se debe pensar su racionalidad; esto, como se ha dicho, con la finalidad de reconocer que la razón se halla realizada en el presente como lo verdaderamente efectivo e identificar, a partir de ello, la parte de absurdo que contiene dicho presente y poder transformarlo conforme a las exigencias de la propia razón.

Aquí de lo que se trata es entonces de $<<$ reconocer la razón como la rosa en la cruz del presente y con ello gozar de éste, esta visión racional es la reconciliación con la realidad que concede la filosofía a aquellos que alguna vez han sentido la exigencia de concebir y tanto de conservar la libertad subjetiva

\footnotetext{
${ }^{305}$ Ibíd., p. 62.
} 
en aquello que es sustancial como de no estar con ella en lo particular y contingente sino en lo que es en sí y para sí>>. 306 En medio del disturbio, la filosofía, a través de la efectividad, permite reconocer a la realidad presente como algo racional, y de esta manera permite reconciliarse con la misma, donde la libertad individual coincide con la libertad sustancial, donde lo particular y contingente se ve subsumido a lo universal y necesario.

La categoría de realidad efectiva permite situarse, pues, en el presente para, por medio de su compresión, efectuar las transformaciones necesarias más apremiantes; lo cual permite, a su vez, dejar de imaginar incesantemente el futuro (esto es, imaginar un porvenir que, aunque se quiera ver esperanzador, por lo pronto se muestra como algo incierto y contingente). Con la categoría de efectividad, Hegel busca sacar a los seres humanos de la ensoñación, de la esperanza en un futuro inalcanzable, y tornarlos conscientes de su capacidad transformadora. Con ella busca hacer conscientes a los seres humanos de lo que ya están realizando, aun inconscientemente, con su propia actividad presente. Así, en política no se trata de depositar la esperanza en una Idea sólo inteligible, esto es, de esperanzarse en un futuro que de antemano se sabe inalcanzable, sino de comprometerse con la actividad práctica, que no es sino guiada por el pensamiento, para la transformación de la realidad presente.

De este modo, en la filosofía de Hegel, la categoría de realidad efectiva no remitiría entonces a aquella "estrella polar" que debiera orientar a todo viajero en su camino, sino al "búho de Minerva" que levanta su vuelo sólo al caer el crepúsculo; de modo que <<para agregar algo más a la pretensión de enseñar cómo debe ser el mundo, señalemos que - dice nuestro autor-, de todos modos, la filosofía llega siempre demasiado tarde. En cuanto pensamiento del mundo, aparece en el tiempo sólo después de que la realidad ha consumado su proceso de formación y se halla ya lista y terminada >>.307 De esta manera, su tratado

\footnotetext{
${ }^{306}$ Ibíd., p. 61.

${ }^{307}$ Ibíd., p. 62-63.
} 
sobre filosofía del derecho, <<en cuanto contiene la ciencia del Estado, no debe ser otra cosa —advierte Hegel— que el intento de concebir y exponer el Estado como algo en sí mismo racional. La enseñanza que puede radicar en él no consiste en enseñar al Estado como debe ser, sino en enseñar cómo él, el universo ético, debe ser conocido $>.308$

Cabe señalar, sin embargo, que el Estado en Hegel no se reduce meramente a una institución jurídico-política, sino que va más allá, se refiere a un todo ético que se está siempre realizando mediante la actividad libre de los seres humanos, se trata de un orden ético en general (símil a la comunidad griega). Con todo, lo cierto es que cuando se ocupa del Estado, nuestro autor no está apostando por una mera idealización del orden estatal, pues de lo contrario, estaría cayendo en aquello que él mismo condenó. Recordemos que en su filosofía del derecho, Hegel mismo afirma que $<<$ cada uno es, de todos modos, hijo de su tiempo; de la misma manera, la filosofía es su tiempo aprehendido en pensamientos $>>$, por lo que resulta igualmente insensato $<<$ creer que una filosofía puede ir más allá de su tiempo presente como que un individuo pueda saltar por encima de su tiempo [...] Si su teoría se ve efectivamente más allá y se construye un mundo tal como debe ser, éste existirá, por cierto, pero sólo en su opinar, elemento dúctil en el que se puede plasmar cualquier cosa $>>.309$

De este modo, nuestro filósofo sostiene que todo pensar es hijo de su tiempo y, por ende, no puede adelantarse al mismo, a no ser que sea de forma arbitraria. En este sentido, el deber ser planteado por los normativistas, en tanto algo meramente abstracto, no tiene nada que anunciar sobre la efectividad del mundo, nada que éste no diga ya a una mirada atenta; tal deber ser únicamente abre un campo ilimitado de posibilidad. Hegel se opone así a todo ideal abstracto, pues en tanto éste se muestra como algo meramente

\footnotetext{
${ }^{308}$ Ibíd., p. 60. [El subrayado es propio].

${ }^{309}$ Ibíd., p. 61.
} 
posible, entonces permite que cualquier otro se coloque como igualmente posible y que sea el entendimiento quien, en última instancia, decida arbitrariamente entre alguno de ellos. ${ }^{310}$

En esta medida, el idealismo hegeliano se opone a toda idea abstracta de un deber ser, pues piensa que tal deber no surge sino de una limitación del pensamiento al no poder pensar efectivamente la realidad (se trata de una especie de refugio para el entendimiento). Hegel se mostró siempre como un crítico de los límites, insistió en que para efectuar una crítica de completa de las cosas deben ser superados sus límites, y estableció que es precisamente sólo a través de su superación que los límites aparecen como límites; de lo contrario, dichos límites aparecerían como meros presupuestos que revelarían una crítica incompleta de las cosas (como de hecho ocurre con muchas filosofías que se pretenden críticas). Empero, el deber ser postulado por el entendimiento, por contradictorio que pudiera parecer, no constituye sino la pretensión de superar los límites establecidos de antemano por el mismo entendimiento. Pero para Hegel, más allá de esta pretensión, el problema reside justo en la limitación preestablecida por el entendimiento, de ahí que en su deber ser no haya más que pura posibilidad, indeterminación, nada seguro.

Así, nuestro filósofo criticó toda esperanza depositada en un tal deber ser, el cual no se fundamenta más que en la idea de un universal abstracto; universal que en realidad se muestra como algo vacío, ya que parece sostenerse en una mera sucesión de momentos, uno detrás de otro, en un desarrollo hacia un más allá que no deriva sino en un "mal infinito". ${ }^{311} \mathrm{Y}$ aunque muchos pensadores se complacen con esta sensación de lo inacabado, Hegel ve en ello una voluntad que se afana a permanecer sin suelo alguno (una autolimitación

${ }^{310}$ Es en este sentido que la filosofía hegeliana se opone a aquellas doctrinas que se fundan en el entendimiento, pues en tanto éste parte de una separación entre lo sensible y lo inteligible, termina por paralizar el proceso reflexivo, lo cual genera que se establezcan dos principios contrapuestos entre lo que tendrá que elegir, y al hacerlo el propio entendimiento termina por caer en el mero arbitrio.

${ }^{311}$ Esta es una categoría hegeliana que alude a la representación del infinito como algo indefinido, lo cual hace que se presente como algo inaprehensible, pero lejos de ser ésta su grandeza, en realidad constituye su defecto, ya que por ser lo inalcanzable es lo no verdadero (no encuentra ningún terreno firme). 
que se niega a ser superada). Es justo esta ausencia eterna de cumplimiento que trae consigo el deber ser, lo que llena de esperanza y cativa al entendimiento, y lo lleva a vivir en la ensoñación (pero el pensamiento especulativo, por el contrario, no se conforma con guardar una esperanza en lo puramente indeterminado, sino que quiere hacerse verdaderamente efectivo, realidad absolutamente efectiva).

En este sentido, el deber ser del normativismo, en tanto representa un más allá inalcanzable, no se revela más que como un rechazo al presente. ${ }^{312}$ Justo el deber ser es un "deber ser" porque no debe ser, o de lo contrario ya no sería tal. El deber ser apunta a un "ser" siempre más allá que no se debe alcanzar para que pueda mantenerse precisamente como "deber ser". El deber ser del normativismo termina por implantar, entonces, un mero acercamiento hacia un fin que, al no poder ser alcanzado alguna vez, se torna eterno. Se trata de una mera aspiración eterna que, por tanto, no contiene esperanza real. Únicamente se puede tener esperanza en un fin si éste puede ser alcanzado; pero si, por el contrario, el fin mismo se anuncia de antemano como inalcanzable, no hay motivos para mantener en él la esperanza. Ésta se elimina entonces a sí misma. La mera esperanza eterna hace que se pierda toda esperanza, con lo que ésta pierde su razón de ser.

Con todo, el normativismo mantiene la esperanza en realizar lo que considera que debe ser en un futuro aún informe. Sin embargo, este deber ser es establecido por una razón que se piensa atemporal y cree, a partir de ello, que los objetivos humanos han sido siempre los mismos en todo tiempo y en todo lugar, sin considerar que ella misma (la razón) se encuentra ya en medio de un proceso histórico que la hace ser de otra manera y que, al mismo tiempo, la

\footnotetext{
${ }^{312}$ El conocimiento siempre lo es del pasado, por lo que del futuro nada se puede decir a no ser más que la esperanza de realizar lo que debe ser. Pero este deber ser, al no poder ponerse en práctica, nos recluye en una constante ensoñación que nos hace ignorar nuestra capacidad transformadora del presente, lo que nos hace, a su vez, rechazar y alejarnos de lo real. El deber ser, en tanto se localiza en un más allá, niega lo ya establecido en el presente, los acontecimientos históricos que han traído hasta el presente lo realmente concreto.
} 
hace transformar sus objetivos de acuerdo a las propias circunstancias (en otras palabras, el normativismo ignora o pretende hacer de lado que la razón se da forma y contenido en la historia misma).

Ignorando que la razón misma se halla transformándose en la historia, la filosofía normativa sigue contraponiendo del modo más natural el ser al deber ser. En cambio, en la filosofía hegeliana el ser y el deber ser no constituyen ya una contraposición absoluta, puesto que están mediados por la presencia efectiva de lo racional. Como ya se ha dicho, para Hegel lo que debe ser ya está de alguna manera realizado en el presente, y esto hace que tal deber ser no sea algo del todo contrapuesto al ser. El presente, en tanto se halla en un movimiento incesante, contiene ya el germen de su transformación futura (aunque la realidad presente está ya completamente realizada, contiene ya el inicio de su propia superación), contiene su propio deber ser.

En resumen, se puede ver que Hegel no abandona del todo el normativismo, pero considera que toda normatividad surge del propio presente, por lo que, si existe un "deber ser", éste no es más que el resultado del desenvolvimiento del presente mismo. Se trata en este caso de un normativismo sui generis: el de la norma como inmanencia. De esta manera, mientras que el normativismo tradicional planteaba que la norma venía de fuera y, por tanto, era algo irrealizable; el "normativismo" hegeliano plantea que la norma es algo interno al mismo proceso de la realidad, por lo que dicha norma se encuentra ya de alguna forma realizada en lo real (aunque sólo sea como momento). En Hegel, el cumplimiento de lo más alto — de las exigencias más altas de la razón - tiene de alguna manera presencia efectiva en lo real, y aquello que se revela como aún no cumplido en la realidad, debe ser precipitado a través de la libre acción humana, no por una exigencia externa, sino porque constituye su propia necesidad interna. 


\section{Conclusión}

$\mathrm{Al}$ recuperar la categoría de realidad efectiva en Hegel, hemos tratado de mostrar que ella nos permite situarnos en el presente para pensarlo desde sí mismo, pues bajo esta categoría dicho presente no se muestra sino como el resultado de la actividad humana que, a través de su libertad, se otorga su propia necesidad. A través de sus actos, el ser humano hace del mundo que habita su propia obra, lo hace algo absolutamente necesario, y la categoría de realidad efectiva trata de llevarnos a la consciencia de ello para reconciliarnos con el mismo. La realidad efectiva nos ha permitido enfrentar, con ello, a aquellas doctrinas normativistas que se apartan del presente y formulan principios prescriptivos que pretenden regular la actividad humana; pero, como hemos visto, tales doctrinas normativas se basan, aun ignorándolo, en un supuesto metafísico que no les permite ir más allá en su actividad crítica.

Podemos decir que, dejándose guiar en cierta medida por una consideración inmediata, la tradición normativa en general ha adoptado una separación entre lo sensible y lo inteligible, por lo que concibe al mundo por un lado y a las ideas por el otro. No obstante, es justo esta oposición la que Hegel pretende destronar con la categoría de realidad efectiva. La categoría de efectividad espera mostrar que no hay una separación entre el ser (mundo sensible) y el pensamiento (mundo inteligible). De acuerdo con la categoría de efectividad las ideas no son meras formas prendidas en el pensamiento y el 
mundo efectivo no es una realidad independiente del pensar, al que únicamente se le pueda observar como algo ajeno a la razón... como algo irracional en sí mismo. La efectividad busca mostrar que no hay ni racionalidad ni objetividad alguna en el mundo a no ser por la actividad del pensamiento. Ser y pensamiento no se excluyen, sino que se necesitan mutuamente para ser; fuera de su unidad no hay nada, ni un pensamiento en sí, ni un ser en sí.313

En la realidad efectiva, la realidad es pensada en su integridad. No obstante, como tratamos de poner en claro a lo largo de la investigación, la realidad efectiva no se identifica con la realidad sin más (lo existente), pero tampoco es otra realidad; es la realidad plenamente reconstituida por la reflexión a partir del conjunto de condiciones - relaciones, determinaciones y circunstancias- que explican su presencia (es decir, a partir de aquello que Hegel llama su esencia). La gran apuesta de Hegel consiste en confiar en que el pensamiento es capaz de concebir la realidad objetivamente. Si por concebir entendemos mostrar (esto es, hacer explícito) el entramado de relaciones que explica la existencia de aquello que se piensa. Lo cual equivale a hacer manifiesta la esencia de ese algo. Con ello el pensamiento transforma a la realidad puramente sensible en una realidad completamente inteligible.

A la conciencia común la realidad se le presenta de inmediato como un dato que está ya $a h i$, sea o no pensado. Ciertamente vivimos en un mundo de cosas, pero la categoría de efectividad intenta mostrar a la consciencia inmediata que tales objetos no son datos, sino resultados. Son resultado de un proceso reflexivo que persigue la síntesis en el objeto pensado. Y la efectividad es justo tomar consciencia de ello.

La realidad efectiva espera llevar al pensamiento ordinario a tomar consciencia de que aquello que se le presenta como inmediato no es en realidad

${ }^{313}$ La reflexión establece una unidad entre el ser y el pensar, forman una unidad indisoluble, donde el uno no puede ser sin el otro. El pensar y lo pensado se identifican o, en otras palabras, el mundo objetivo y el pensamiento son uno. Ser y pensar son una y la misma cosa. 
sino por un proceso, aquél en el que la reflexión reconstituye lo inmediato a través de la totalidad de condiciones que explican que ese inmediato aparezca como tal a la consciencia. Es la explicación de por qué lo inmediato se presenta como inmediato, es la explicitación del proceso que lleva a lo que ya vivimos como mundo. La realidad efectiva consiste en pensar la existencia de un objeto en medio del mecanismo que lo ha estructurado como tal. La verdad del objeto sólo se muestra en su esfuerzo por pensarle. La realidad efectiva es la toma de consciencia del proceso que ha hecho ser al objeto de experiencia tal como es.

Cuando el pensamiento constata este proceso, reconoce su presencia como mundo efectivo. En efecto, con la categoría de realidad efectiva el pensamiento no abandona este mundo yendo más allá del mismo ni tampoco se recluye en sí mismo. En la realidad efectiva no hay pura interioridad ni simple exterioridad, no hay nada inaccesible o inalcanzable. No queda ningún residuo de realidad o de pensamiento que se pueda reclamar independiente. La categoría de efectividad previene contra toda adulación de un más allá, pero también contra toda sacralización de un más acá; ambas representan abstracciones que se fundan en determinadas posturas metafísicas a las que el pensamiento especulativo combate. Es por eso que lo que está aquí en juego, como hemos advertido, es la compresión de una cierta metafísica.

La realidad efectiva concentra el proceso por el que, en un doble movimiento simultáneo, el pensamiento reconstituye reflexivamente al objeto pensado a la vez que se reconstituye a sí mismo reflexionando sobre su actividad. En suma, la categoría de efectividad concentra en un mismo movimiento al pensamiento pensante, aquél que reflexiona sobre la cosa convirtiéndola con ello en objeto de experiencia, y al pensamiento pensado, aquél que reflexionando sobre la transformación que realiza en el objeto no reflexiona sino sobre sí mismo. Es el pensamiento que se piensa a sí mismo pensando, es decir: el pensamiento especulativo (speculum). Es el pensamiento que metafóricamente se ve a sí mismo en $s u$ otro como en un espejo, y que 
literalmente se piensa a sí mismo pensando a $s u$ otro. Se trata de una indagación de lo real a la que se arroja el pensamiento para concebir su verdad, pero no es sino en el esfuerzo por pensarle que le constituye enteramente en su verdad.

A partir de esto, podemos observar que la categoría de realidad efectiva también opera en el dominio político, y es con ella, como se ha visto, que nuestro autor combate las doctrinas normativas del deber ser. La crítica que Hegel dirige al normativismo consiste, no en oponerle otro principio que considere más racional, pues ello sería igualmente arbitrario, sino en mostrar que desde sus propios términos, la filosofía normativa es insuficiente para dar cuenta de lo que se propone. Ciertamente la filosofía hegeliana se arriesga en la tesis de que el mundo es absolutamente necesario, pero el que sea necesario no significa que el mundo deba ser como es, sino que en tanto obra del ser humano, es comprensible para la razón humana (comprensión y justificación no se identifican).

Y es justo la compresión de su necesidad, la que permite apartar del mundo aquella parte de absurdo y contingencia que siempre ya contiene ${ }^{314}$, sin tener que recurrir a la imagen de un mundo ideal. Esto convierte a Hegel en un profundo crítico de la filosofía kantiana y de todas aquellas que se basan en la formulación de mundos ideales, pues su filosofía trata de pensar el mundo tal como es (con su contingencia y necesidad), y no cómo debe ser según una Idea de la razón. Así, una vez que la Lógica hegeliana ha mostrado que la razón es capaz de pensar la necesidad absoluta del mundo, se puede hacer una crítica a Kant con respecto a la esterilidad que trae consigo el idear cómo ha de ser el mundo político, si en realidad podemos alcanzar un conocimiento genuino del mismo.

\footnotetext{
${ }^{314}$ Lo contingente sólo es tal porque contradice el momento racional que ha alcanzado la propia razón en la historia. La razón crea sus propios criterios de racionalidad.
} 
Es importante mencionar que Hegel no considera las Ideas de la razón como un sinsentido, pues ciertamente pueden cumplir una función crítica, pero, de acuerdo con nuestro autor, ésta queda incompleta si se carece de un conocimiento verdadero sobre la realidad. Así, las Ideas se erigirán como una estrella polar que guiarán nuestro camino, pero que, cuando mengue nuestra esperanza de alcanzar el fin (de antemano declarado como imposible), bien podemos desistir y nos apartarnos del camino.

A grandes rasgos Hegel puede ser considerado como un crítico de los límites de la razón y, por ende, de los ideales que se colocan como atenuante a su finitud. Nuestro filósofo destina la categoría de realidad efectiva a pensar la necesidad del presente para invitarnos a transformar nuestras condiciones de vida. Es así que comprende a la filosofía como el esfuerzo por pensar al pensamiento en su propio desenvolvimiento. De ahí que el objeto de la filosofía política será pensar la razón suficiente del orden estatal. Su labor consistirá en mostrar la estructura racional de lo real, en este caso del Estado, para que el individuo lo identifique como la obra de su libertad, aquella forma que su libertad ha adoptado como su propia necesidad. Hegel parece perseguir aquí la unidad entre necesidad antigua y libertad moderna.

Así, cuando el individuo ocupe su lugar dentro del orden estatal, se identificará con dicho orden, pues éste no es más que la encarnación de su razón. El sujeto encontrará su encarnación en el Estado y comprenderá que éste nació de la entera voluntad humana como encarnación del espíritu libre. El individuo comprenderá al Estado como un orden que se ha desplegado necesariamente a través de la historia, y por ello no tiene la necesidad de buscar un deber ser que le sirva de guía para crear un Estado idealmente racional, porque el que vive ya lo es. En el Estado, el individuo llega a saberse uno con el presente que ha realizado históricamente, a través del cual se ha dado a sí mismo forma; es aquí donde alcanza su plena libertad: el saberse libre 
en su propia necesidad. De este modo el ser humano al fin se sabe en casa (bei sich).

Hegel no plantea un Estado ideal, del cual los seres humanos se lamenten por no realizar. De acuerdo con nuestro autor no existe la necesidad de soñar con un Estado idealmente justo, si la justicia es algo que los seres humanos ya están realizando en el mundo con su actividad, incluso aun sin ser conscientes de ello (o por lo menos no plenamente). En efecto, Hegel tiene la convicción de que la justicia y la libertad, lejos de ser meros ideales de la razón, son obras que se están ya realizando; por lo que no es necesario postular un más allá donde se realizarían. Con la categoría de realidad efectiva Hegel no evade pensar el presente desde sí mismo, como lo hacen muchas filosofías, sino que logra pensarlo efectivamente en su incesante proceso.

La filosofía hegeliana centrada en la categoría de efectividad sólo busca hacer conscientes a los seres humanos de que el mundo sólo es por su actividad teórico-práctica ${ }^{315}$, de que el mundo no es en realidad sino su mundo. Todo con la finalidad de precipitar el advenimiento de aquello que la razón ha reconocido como justo. Hegel pretende tornar conscientes a los seres humanos de que son los dueños de sus circunstancias con el objetivo de que se reconcilien con su mundo. Su filosofía se centra, no en la intención, sino en la actividad para la transformación del mundo, confiando en que el temor a errar es ya vivir en el error.

\footnotetext{
${ }^{315}$ Ciertamente, para Hegel sin práctica no hay teoría, pero sin teoría tampoco hay práctica.
} 


\section{Bibliografía}

Allison, Henry (1992), El idealismo trascendental de Kant: una interpretación y defensa, Anthropos, Barcelona.

— (1996) Idealism and Freedom, Cambridge University Press, Cambridge.

Álvarez, Mariano y María Paredes (eds.) (2004), La controversia de Hegel con Kant, Universidad de Salamanca, Salamanca.

Aristóteles (2004), Política, Tecnos, Madrid.

Avineri, Shlomo (1972), Hegel's theory of the Modern State, Cambridge University Press, Cambridge.

Bloch, Ernst (1983), Sujeto-objeto: El pensamiento de Hegel, FCE, México.

Bourgeois, Bernard (1972), El pensamiento político de Hegel, Amorrortu, Buenos Aires.

Carvajal Cordón, Julián (coord.) (1999), Moral, derecho y política en Immanuel Kant, Universidad de Castilla-La Mancha, Cuenca.

Cassirer, Ernst (1968), Kant, vida y doctrina, FCE, México.

D’ Hondt, Jacques (1971), Hegel, filósofo de la historia viviente, Amorrortu, Buenos Aires. 
Di Giovanni, George (ed.) (1990), Essays on Hegel's Logic, State University of New York Press, New York.

Grondin, Jean, (2006), Introducción a la metafísica, Herder, Barcelona.

Guzmán, Luis (2006), "El carácter contingente de la necesidad absoluta en la Ciencia de la lógica de Hegel”, Bogotá.

Hegel, G. W. F., Gesammelte Werke, ed. Nordrhein-Westfälische Akademie der Wissenschaften, Hamburg, Felix Meiner Verlang (1967).

_ (1955), Lecciones sobre la historia de la filosofía II, FCE, México.

— (1966), Fenomenología del espíritu, FCE, México.

(1974), Ciencia de la lógica, Solar/Hachette, Buenos Aires.

(1989), Lecciones sobre la filosofía de la historia universal, Alianza, Madrid.

— (1991), The Encyclopaedia Logic, Hackett Publishing Company, Indianapolis-Cambridge.

—_ (1999), Principios de la filosofía del derecho, Edhasa, Barcelona.

—_ (1999), Enciclopedia de las ciencias filosóficas, Alianza, Madrid.

— (2011), Ciencia de la lógica, Abada, Madrid.

Henrich, Dieter (1987), Hegel en su contexto, Monte Ávila, Caracas. 
Höffe, Otfried (1986), Immanuel Kant, Herder, Barcelona.

Hyppolite, Jean (1978), Lógica y existencia: Ensayo sobre la lógica de Hegel, Universidad Autónoma de Puebla, Puebla.

Kant, Immanuel, Gesammelte Schriften, herausgegeben von der Königlich Preußischen Akademie der Wissenschaften, Berlín (1902).

—_ (1977), Crítica de la razón práctica, Losada, Buenos Aires.

— (1986), Teoría y práctica, Tecnos, Madrid.

— (1989), Metafísica de las costumbres, Tecnos, Madrid.

— (1995), Fundamentación de la metafísica de las costumbres, Espasa Calpe, Madrid.

—_ (1996), Sobre la paz perpetua, Tecnos, Madrid.

— (2000), Lógica, Akal, Madrid.

—_ (2001), La religión dentro de los límites de la mera razón, Alianza, Madrid.

— (2003), Pedagogía, Akal, Madrid.

— (2003), Crítica del discernimiento, Antonio Machado Libros, Madrid.

—— (2004), Crítica de la razón pura, Losada, Buenos Aires.

— (2005), Prolegómenos a toda metafísica del futuro, Losada, Buenos Aires. 
Kersting, Wolfgang (2001), Filosofía política del contractualismo moderno, Plaza y Valdés, México.

Körner, Stephan (1977), Kant, Alianza, Madrid.

Laslett, Peter (1964), Philosophy, Politics and Society, Blackwell, Cambridge.

Longuenesse, Béatrice (2007), Hegel's Critique of Metaphysics, Cambridge University press, New York.

Lukács, G. (1981), El joven Hegel (y los problemas de la sociedad capitalista), Grijalbo, Barcelona.

Marcuse, Herbert (1971), Razón y revolución: Hegel y el surgimiento de la teoría social, Alianza, Madrid.

Marrades, Julián (2001), El trabajo del espíritu. Hegel y la modernidad, Antonio Machado Libros, Madrid.

Mure, G.R.G. (1988), La filosofía de Hegel, Cátedra, Madrid.

Nöel, Georges (1995), La lógica de Hegel, Universidad Nacional de Colombia, Bogotá.

Peperzak, Adriaan (1987), Philosophy and Politics. A commentary on the Preface to Hegel's Philosophy of Right, Martinus Nijhoff, Dordrecht.

Pérez, Sergio, "Hegel, crítico de Bloch", contenido en Pérez, Sergio, Víctor Alarcón, César Cansino (coord.) (1988), Ernst Bloch: Sociedad, Política y Filosofía, UAM-CIDE, México.

(1989), La política del concepto, UAM, México. 
Platón (1971), La República, UNAM, México.

Rendón, Jorge (2007), Filosofía política: sus clásicos y sus problemas actuales, UAM, México.

Serrano Gómez, Enrique (2004), La insociable sociabilidad: El lugar y la función del derecho y la política en la filosofía práctica de Kant, Anthropos, Barcelona.

Sprute, Jürgen (2008), Filosofía política de Kant, Tecnos, Madrid.

Stepanenko, Pedro (2000), Categorías y autoconciencia en Kant, UNAM, México.

Taylor, Charles (2010), Hegel, Anthropos, Barcelona. 